U.S. Department of the Interior

U.S. Geological Survey

\title{
River and Reservoir Operations Model, Truckee River Basin, California and Nevada, 1998
}

Water-Resources Investigations Report 01-4017

Prepared in cooperation with the

TRUCKEE-CARSON PROGRAM

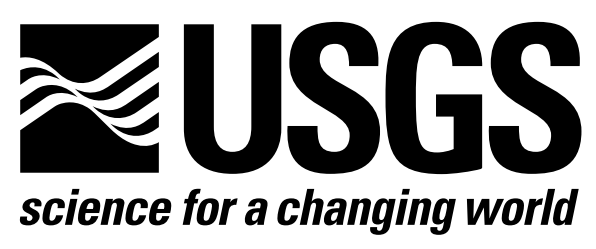


RIVER AND OPERATIONS MODEL, TRUCKEE RIVER BASIN, CALIFORNIA AND NEVADA, 1998 


\section{River and Reservoir Operations Model, Truckee River Basin, California and Nevada, 1998}

By Steven N. Berris, Glen W. Hess, and Larry R. Bohman

U.S. GEOLOGICAL SURVEY

Water-Resources Investigations Report 01-4017

Prepared in cooperation with the

TRUCKEE-CARSON PROGRAM 


\title{
U.S. DEPARTMENT OF THE INTERIOR GALE A. NORTON, Secretary
}

\author{
U.S. GEOLOGICAL SURVEY
}

CHARLES G. GROAT, Director

Any use of trade, product, or firm names in this publication is for descriptive purposes only and does not imply endorsement by the U.S. Government

For additional information contact:

District Chief

U.S. Geological Survey

333 West Nye Lane, Room 203

Carson City, NV 89706-0866

email: GS-W-NVpublic-info@usgs.gov

http://nevada.usgs.gov 


\section{CONTENTS}

Abstract ...

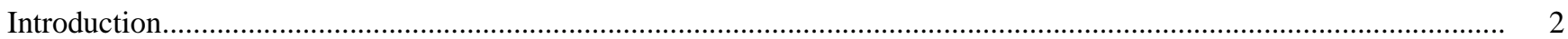

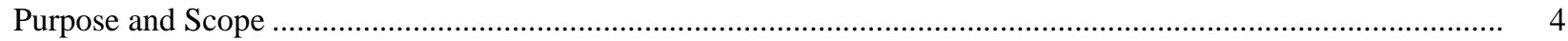

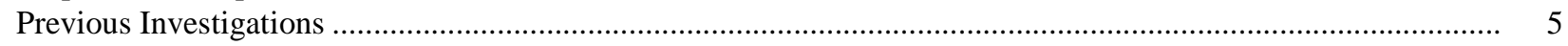

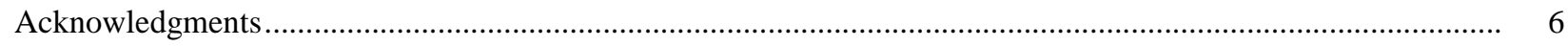

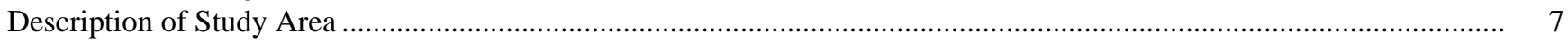

Lake Tahoe and Upper Truckee River Subunit............................................................................................ 8

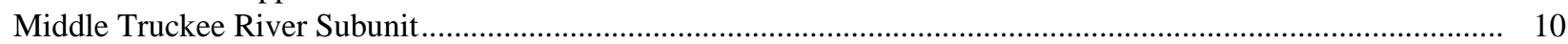

Lower Truckee River and Pyramid Lake Subunit.................................................................................. 12

Chronology and Background of Decrees, Agreements, and Laws Affecting Operations ............................................... 14

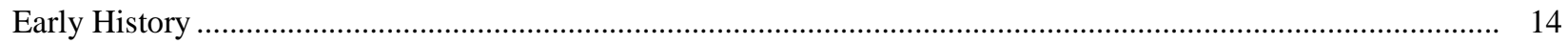

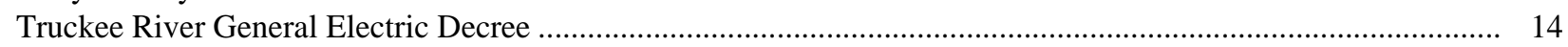

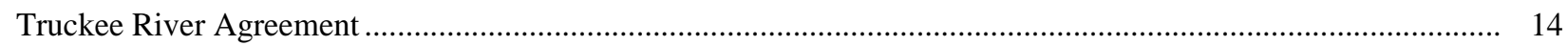

Construction of Additional Storage Reservoirs in the 1930's ........................................................................... 15

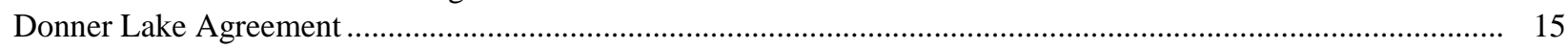

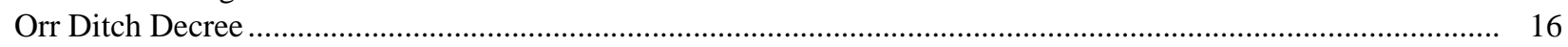

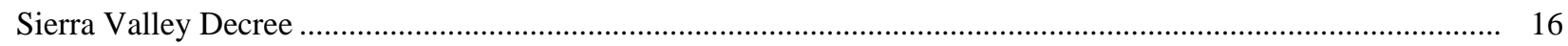

Construction of Prosser Creek and Stampede Dams.................................................................................... 16

Tahoe-Prosser Exchange Agreement .................................................................................................... 16

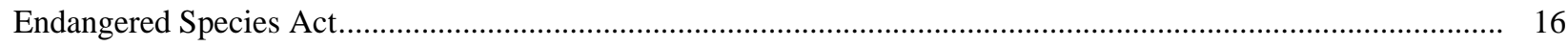

Stampede Reservoir Judgement ........................................................................................................... 17

Newlands Project Operating Criteria and Procedures..................................................................................... 17

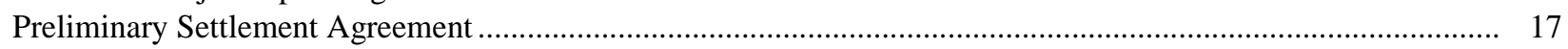

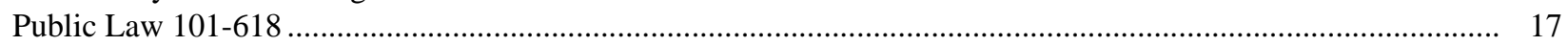

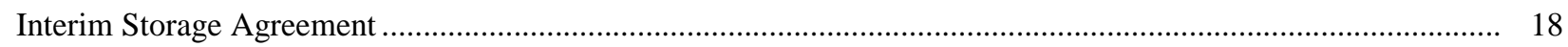

Truckee River Water Quality Settlement Agreement ............................................................................. 18

Construction of Truckee River Basin Operations Model ...................................................................................... 19

Description of Hydrological Simulation Program-FORTRAN ……................................................................ 20

Flow-Routing Model .................................................................................................................................. 22

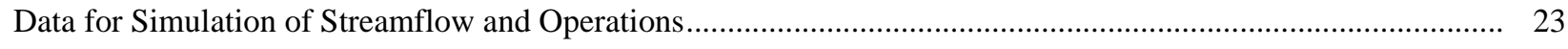

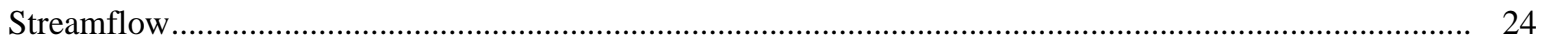

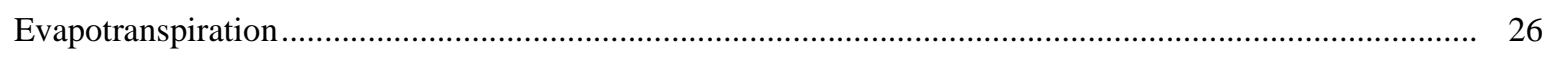

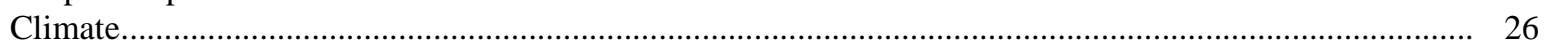

Municipal and Industrial Demands.................................................................................................... 27

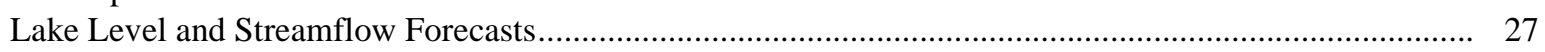

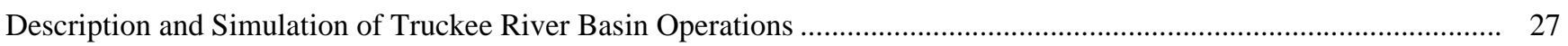

Description and Simulation of Current Operations ........................................................................................ 32

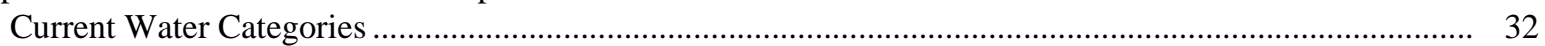

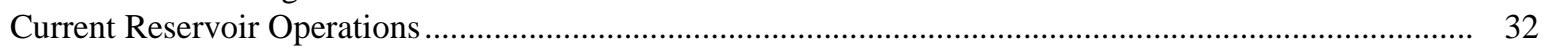

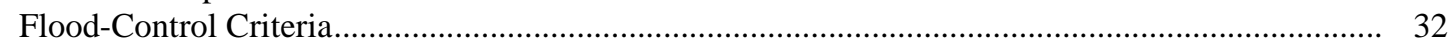

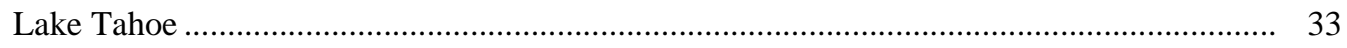

Donner Lake ……................................................................................................... 34

Martis Creek Lake ................................................................................................ 34

Prosser Creek Reservoir ................................................................................................. 35

Independence Lake ................................................................................................... 35

Stampede and Boca Reservoirs ..................................................................................... 36

Lahontan Reservoir.................................................................................................... 36

Reservoir Storage Priorities and Pass-Throughs ……................................................................. 37

Storage Priorities ……….......................................................................................... 37

Reservoir Pass-Throughs and Releases to Meet Newlands Project Demands......................... 39

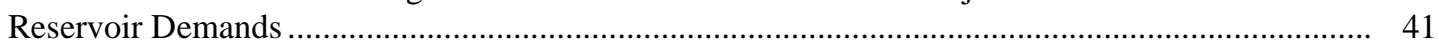




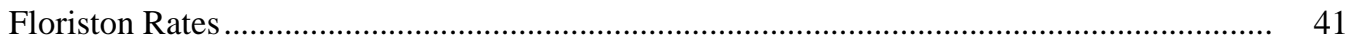

Minimum Instream Flows ................................................................................. 44

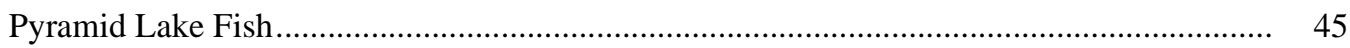

Privately Owned Stored Water ................................................................................. 48

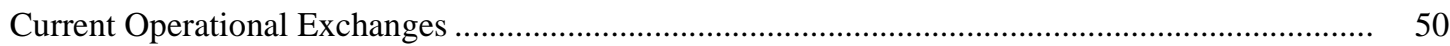

Tahoe-Prosser Exchange........................................................................................ $\quad 50$

Donner-Boca Exchange ................................................................................................ 51

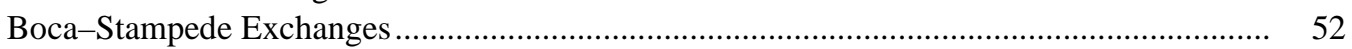

Merge Reservoir Releases for Multiple Objectives ................................................................... 53

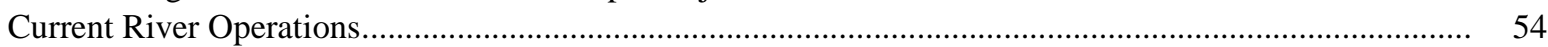

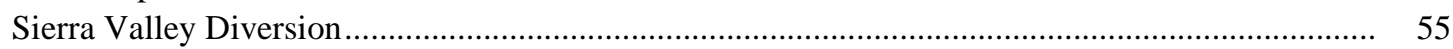

Truckee Meadows Diversions ...................................................................................................... 57

Lower Truckee River Diversions .............................................................................................. 58

Truckee River Diversions to Newlands Project ..................................................................... 61

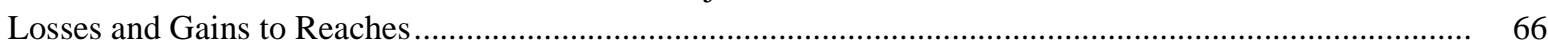

Description and Simulation of Operations Under Draft Truckee River Operating Agreement and

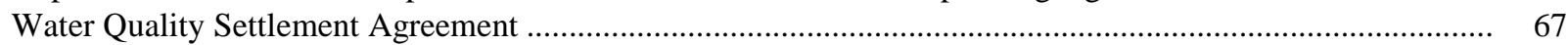

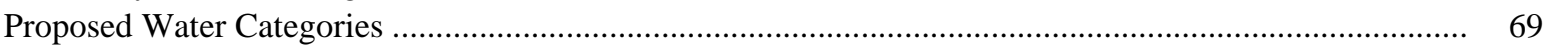

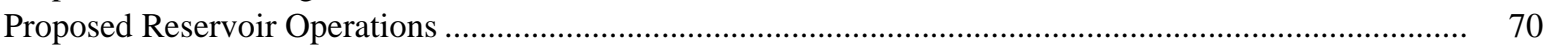

Storage of Proposed Water Categories ....................................................................................... $\quad 70$

California Municipal and Industrial Credit Water................................................................. $\quad 70$

Power Company Municipal and Industrial Credit Water, Fish Credit Water,

Water-Quality Credit Water, and Joint Program Fish Credit Water................................. $\quad 72$

Reservoir Releases to Meet Downstream Demands ........................................................................ 80

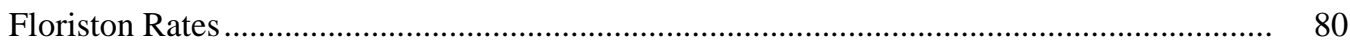

Power Company Municipal and Industrial Credit Water ...................................................... 82

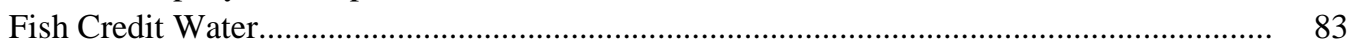

California Municipal and Industrial Credit Water............................................................... 84

Diversion of Water in Lake Tahoe and Donner and Independence Lakes for Municipal and Industrial Use in California............................................................... $\quad 85$

Water-Quality Targets and Related Instream Flow Transfers ............................................. $\quad 85$

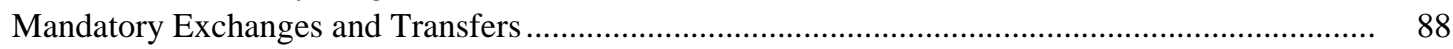

Enhanced Minimum Instream Flows....................................................................... 88

Other Exchanges and Transfers ............................................................................ 93

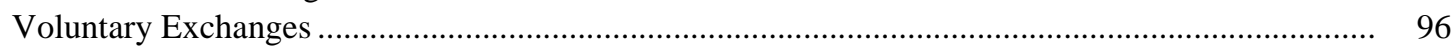

Preferred Instream Flows.................................................................................... 97

Enhanced Storage Security and Access ...................................................................... 101

Exchanges from Lake Tahoe or Prosser Creek Reservoir to Boca Reservoir............. 102

Exchanges from Boca Reservoir to Stampede Reservoir ........................................... 102

Efficient Use of Releases for Precautionary Drawdowns................................................... 104

Maintenance of Recreational Pools .................................................................................. 105

Merge Reservoir Releases for Multiple Objectives ................................................................ 108

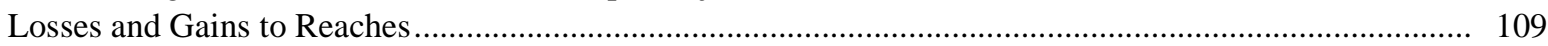

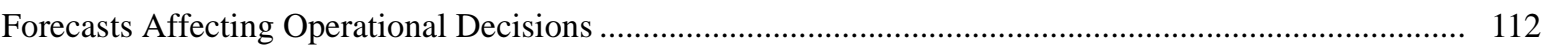

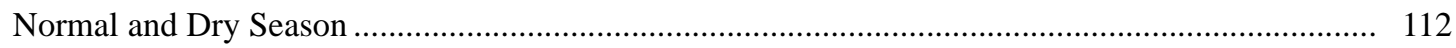

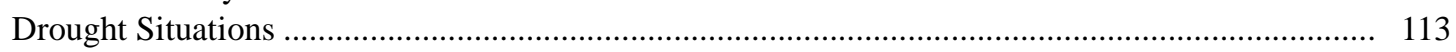

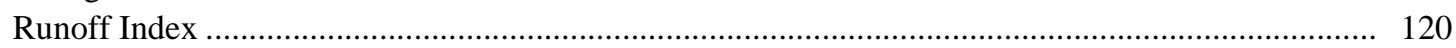

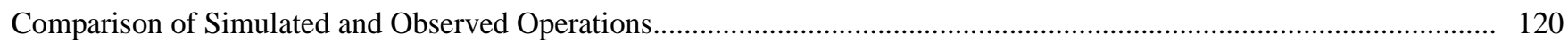

Model Limitations, Assumptions, and Suggested Improvements ......................................................................... 125

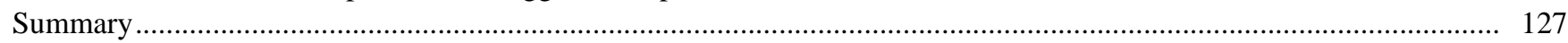

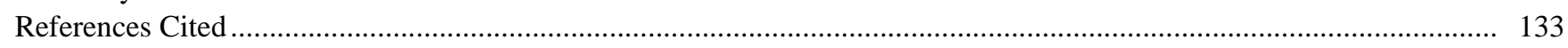

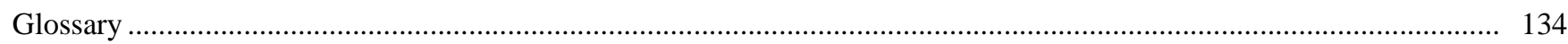




\section{PLATE}

Map showing hydrologic features, model lake/reservoir and river/canal reaches, and selected data-collection sites of Truckee River, Truckee Canal, and Lahontan Reservoir, California and Nevada

\section{FIGURES}

1. Map showing location of study area, California and Nevada

2. Map showing hydrologic features, river reaches, and hydrologic subunits of the Truckee River Basin .....

3. Schematic diagram showing the river and reservoir reaches, outflows, and inflows for the

U.S. Geological Survey Truckee River Basin operations model

4. Generalized flowchart of U.S. Geological Survey Truckee River Basin operations model......................................... 29

5. Determination of normal or dry seasons for Lake Tahoe, February-June 113

6. Determination of normal or dry seasons for Donner Lake, Prosser Creek Reservoir, Independence Lake,

Stampede Reservoir, and Boca Reservoir, February-June

7. Observed and simulated monthly mean streamflows for the period October 1, 1988, through

September 30, 1997, for Truckee River at Farad, Calif. (station 10346000)

8. Observed and simulated monthly mean streamflows for the period October 1, 1988, through

September 30, 1997, for Truckee River at Vista, Nev. (station 10350000) 123

9. Observed and simulated monthly mean streamflows for the period October 1, 1988, through

September 30, 1997, for Truckee River at Nixon, Nev. (station 10351700) 124

\section{TABLES}

1. Selected characteristics of major reservoirs.

2. Floriston rates as related to Lake Tahoe water-surface elevation and month

3. June through December end-of-month storage objectives for Lahontan Reservoir from 1988 and Adjusted

Operating Criteria and Procedures 18

4. Fish flow targets to optimize spawning success by regulation of flows at Truckee River near Nixon, Nevada............. 47

5. Tagged and untagged releases from reservoirs for current operations ............................................................. 55

6. Rank order of water categories assigned to untagged releases, by reservoir under current operations ........................ 56

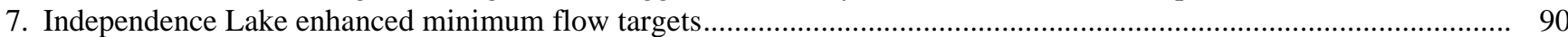

8. Assumed preferred instream flow targets downstream of reservoirs................................................................. 99

9. Rank order of water categories assigned to untagged releases under Truckee River Operating Agreement and Water Quality Settlement Agreement 
CONVERSION FACTORS, VERTICAL DATUM, AND ACRONYMS

\begin{tabular}{rll}
\hline Multiply & By & To obtain \\
\hline cubic foot per second $\left(\mathrm{ft}^{3} / \mathrm{s}\right)$ & 0.02832 & cubic meter per second \\
acre & 0.02832 & cubic meter per second per day \\
cubic feet per second per day $\left(\mathrm{ft}^{3} / \mathrm{s} / \mathrm{d}\right)$ & 4,047 & cubic meter \\
acre-foot $(\mathrm{acre}-\mathrm{ft})$ & 1,233 & cubic meter per year \\
acre-foot per year (acre-ft/yr) & 1,233 & meter \\
foot (ft) & 0.3048 & millimeter \\
inch (in.) & 25.4 & millimeter per year \\
inches per year (in/yr) & 25.4 & kilometer \\
mile (mi) & 1.609 & square kilometer \\
square mile $\left(\mathrm{mi}^{2}\right)$ & 2.590 &
\end{tabular}

Temperature: Degrees Celsius $\left({ }^{\circ} \mathrm{C}\right)$ can be converted to degrees Fahrenheit $\left({ }^{\circ} \mathrm{F}\right)$ by using the formula ${ }^{\circ} \mathrm{F}=\left[1.8\left({ }^{\circ} \mathrm{C}\right)\right]+32$. Degrees Fahrenheit can be converted to degrees Celsius by using the formula ${ }^{\circ} \mathrm{C}=0.556\left({ }^{\circ} \mathrm{F}-32\right)$.

Sea level: In this report, "sea level” refers to the National Geodetic Vertical Datum of 1929 (NGVD of 1929, formerly called "Sea-Level Datum of 1929"), which is derived from a general adjustment of the first-order leveling networks of the United States and Canada.

\section{ACRONYMS:}

BOR: Bureau of Reclamation

CDWR: California Department of Water Resources

CMICW: California M\&I credit water

EIS/EIR: environmental impact statement/environmental impact report

EPA: Environmental Protection Agency

ESA: Endangered Species Act

ESP: Extended Streamflow Prediction

ET: Evapotranspiration

FCW: Fish Credit Water

F-TABLE: Function table within Hydrological Simulation Program-FORTRAN

FWM: U.S. District Court Water Master (commonly referred to as the Federal Water Master)

GENSCN: Generation and Analysis of Model Simulation Scenarios

HSPF: Hydrological Simulation Program-FORTRAN

JPFCW: Joint Program Fish credit water

M\&I: Municipal and industrial

MAD: Maximum allowable diversion

NDEP: Nevada Division of Environmental Protection

NRCS: Natural Resources Conservation Service

NWS: National Weather Service

OCAP: Operating Criteria and Procedures

PCEDS: Power Company emergency drought supply

PCMICW: Power Company M\&I credit water

PCPOSW: Power Company privately owned stored water

P.L.: Public Law

PRMS: Precipitation-Runoff Modeling System

POSW: Privately owned stored water

PSA: Preliminary Settlement Agreement

RCHRES: Reach-reservoir block within Hydrological Simulation Program-FORTRAN

SPECL: Special actions block within Hydrological Simulation Program-FORTRAN

SPPC: Sierra Pacific Power Company

TCID: Truckee-Carson Irrigation District

TCIDPOSW: Truckee-Carson Irrigation District privately-owned stored water

TMUGL: Truckee Meadows ungaged gains and losses 
TMWRF: Truckee Meadows Water Reclamation Facility

TPEW: Tahoe-Prosser Exchange water

TROA: Truckee River Operating Agreement

UCI: User's control input for Hydrological Simulation Program-FORTRAN

USCOE: U.S. Army Corps of Engineers

USFWS: U.S. Fish and Wildlife Service

USGS: U.S. Geological Survey

WCWCD: Washoe County Water Conservation District

WDM: Watershed Data Management

WQCW: Water-quality credit water

WQSA: Water Quality Settlement Agreement

\section{NOTICE}

The customized software application and supporting materials (data and documentation) presented herein are made available by the U.S. Geological Survey (USGS) to be used in the public interest and for the advancement of science. The authors, USGS, or the United States Government assume no liability for the contents or the use thereof. This documentation does not constitute a standard, specification, or regulation. 
VIII RIVER AND OPERATIONS MODEL, TRUCKEE RIVER BASIN, CALIFORNIA AND NEVADA, 1998 


\title{
River and Reservoir Operations Model, Truckee River Basin, California and Nevada, 1998
}

\author{
By Steven N. Berris, Glen W. Hess, and Larry R. Bohman
}

\section{ABSTRACT}

The demand for all uses of water in the Truckee River Basin, California and Nevada, commonly is greater than can be supplied. Storage reservoirs in the system have a maximum effective total capacity equivalent to less than two years of average river flows, so longer-term droughts can result in substantial water-supply shortages for irrigation and municipal users and may stress fish and wildlife ecosystems. Title II of Public Law (P.L.) 101-618, the Truckee-Carson-Pyramid Lake Water Rights Settlement Act of 1990, provides a foundation for negotiating and developing operating criteria, known as the Truckee River Operating Agreement (TROA), to balance interstate and interbasin allocation of water rights among the many interests competing for water from the Truckee River. In addition to TROA, the Truckee River Water Quality Settlement Agreement (WQSA), signed in 1996, provides for acquisition of water rights to resolve waterquality problems during low flows along the Truckee River in Nevada. Efficient execution of many of the planning, management, or environmental assessment requirements of TROA and WQSA will require detailed water-resources data coupled with sound analytical tools. Analytical modeling tools constructed and evaluated with such data could help assess effects of alternative operational scenarios related to reservoir and river operations, water-rights transfers, and changes in irrigation practices.

The Truckee-Carson Program of the U.S. Geological Survey, to support U.S. Department of the Interior implementation of P.L. 101-618, is developing a modeling system to support efficient water-resources planning, management, and allocation. The daily operations model documented herein is a part of the modeling system that includes a database management program, a graphical user interface program, and a program with modules that simulate river/reservoir operations and a variety of hydrologic processes. The operations module is capable of simulating lake/ reservoir and river operations including diversion of Truckee River water to the Truckee Canal for transport to the Carson River Basin. In addition to the operations and streamflow-routing modules, the modeling system is structured to allow integration of other modules, such as water-quality and precipitation-runoff modules.

The USGS Truckee River Basin operations model was designed to provide simulations that allow comparison of the effects of alternative management practices or allocations on streamflow or reservoir storages in the Truckee River Basin over long periods of time. Because the model was not intended to reproduce historical streamflow or reservoir storage values, a traditional calibration that includes statistical comparisons of observed and simulated values would be problematic with this model and database.

This report describes a chronology and background of decrees, agreements, and laws that affect Truckee River operational practices; the construction of the Truckee River daily operations model; the simulation of Truckee River Basin operations, both current and proposed under the draft TROA and WQSA; and suggested model improvements and limitations. The daily operations model uses Hydrological Simulation Program-FORTRAN (HSPF) to simulate flowrouting and reservoir and river operations. The operations model simulates reservoir and river operations that govern streamflow in the Truckee 
River from Lake Tahoe to Pyramid Lake, including diversions through the Truckee Canal to Lahontan Reservoir in the Carson River Basin. A general overview is provided of daily operations and their simulation. Supplemental information that documents the extremely complex operating rules simulated by the model is available.

\section{INTRODUCTION}

The Truckee River has had a long history of providing water to a variety of economic and environmental users. Truckee River water is used for power generation upstream from Reno, municipal and industrial (M\&I; bold non-italicized words are defined in the glossary) supply for the Lake Tahoe vicinity, town of Truckee, and the Reno-Sparks vicinity (hereafter referred to as the Truckee Meadows), and irrigation in both the Truckee and Carson River Basins. The Truckee River discharges into Pyramid Lake (fig. 1), and thus sustains lake levels and provides flows for spawning of the endangered cui-ui lakesucker and the threatened Lahontan cutthroat trout. The diversity of user interests, each with a demand on the limited water resource, has resulted in long-standing and intense conflicts among various economic, political, ecological, and institutional entities. The diversity in interests also provides a wide range of alternatives for planning, allocating, and managing the water resources and operating the various reservoir and diversion facilities.

The demand for all uses of water in the Truckee River Basin, California and Nevada, commonly is greater than can be supplied. Storage reservoirs in the system have a maximum effective total capacity equivalent to less than two years of average river flows. Droughts lasting several years, such as the recent drought of the late 1980's and early 1990's, can cause substantial water shortages for irrigation and municipal users and may stress fish and wildlife ecosystems.

Title II of Public Law (P.L.) 101-618, the Truckee-Carson-Pyramid Lake Water Rights Settlement Act of 1990 (104 Statute 3289), provides direction, authority, and mechanisms for resolving conflicts over water and water rights in the Truckee and Carson River Basins. A major element of P.L. 101-618, known as the Truckee River Operating Agreement (TROA), provides a foundation for improving water management and for negotiating and developing operating criteria to balance interstate and interbasin allocation of water rights among the many competing interests for Truckee River water. In addition to TROA, the Truckee River Water Quality Settlement Agreement (WQSA), signed in 1996, provides for acquisition of water rights to aid in resolving water-quality problems in the Truckee River in Nevada during low-flow periods while simultaneously providing additional water for fish and wildlife resources. Efficient execution of many of the planning, management, or environmental assessment requirements of TROA and WQSA will require detailed water-resources data. Analytical modeling tools constructed and evaluated with such data could help assess effects of alternative management and operational scenarios related to Truckee River operations, including water-rights transfers, changes in irrigation practices, and changes in demand patterns.

Daily, physically based models capable of simulating alternative management policies for river and reservoir operations are needed to assess alternatives for water management. The interdependence of many of the water-management issues of the Truckee River Basin, such as allocation of streamflow and achieving instream water-quality standards, suggests a strong need for an overall data-management and modeling system within which individual issues can be addressed in an efficient and coordinated manner. In addition, there is a need for a model that can provide the riverhydraulics and daily-flow data to other quantitative tools, such as water-quality models. Such a model needs to be interbasin in scope, addressing the interrelated management issues of the Truckee River, the Carson River, and the Truckee Canal, which facilitates the diversion of water from the Truckee River to Lahontan Reservoir in the Carson River Basin. The model needs to be fully documented and in the public domain, so that all stakeholders are confident in the system and they can all work from a common base or point of reference.

The dynamic nature of certain operations and management issues along the Truckee River requires a model computation interval that is daily, rather than monthly. Water-quality problems cannot be examined satisfactorily on a monthly time step. Temperature, dissolved oxygen, and other water-quality parameters often require daily or even hourly temporal resolution. In order to reflect actual river and reservoir operations, models should be capable of simulating brief hydrologic "pulses" in the system. Such short-term opportunities resulting from storm runoff lasting one week or less may allow for storage or exchange of credit 


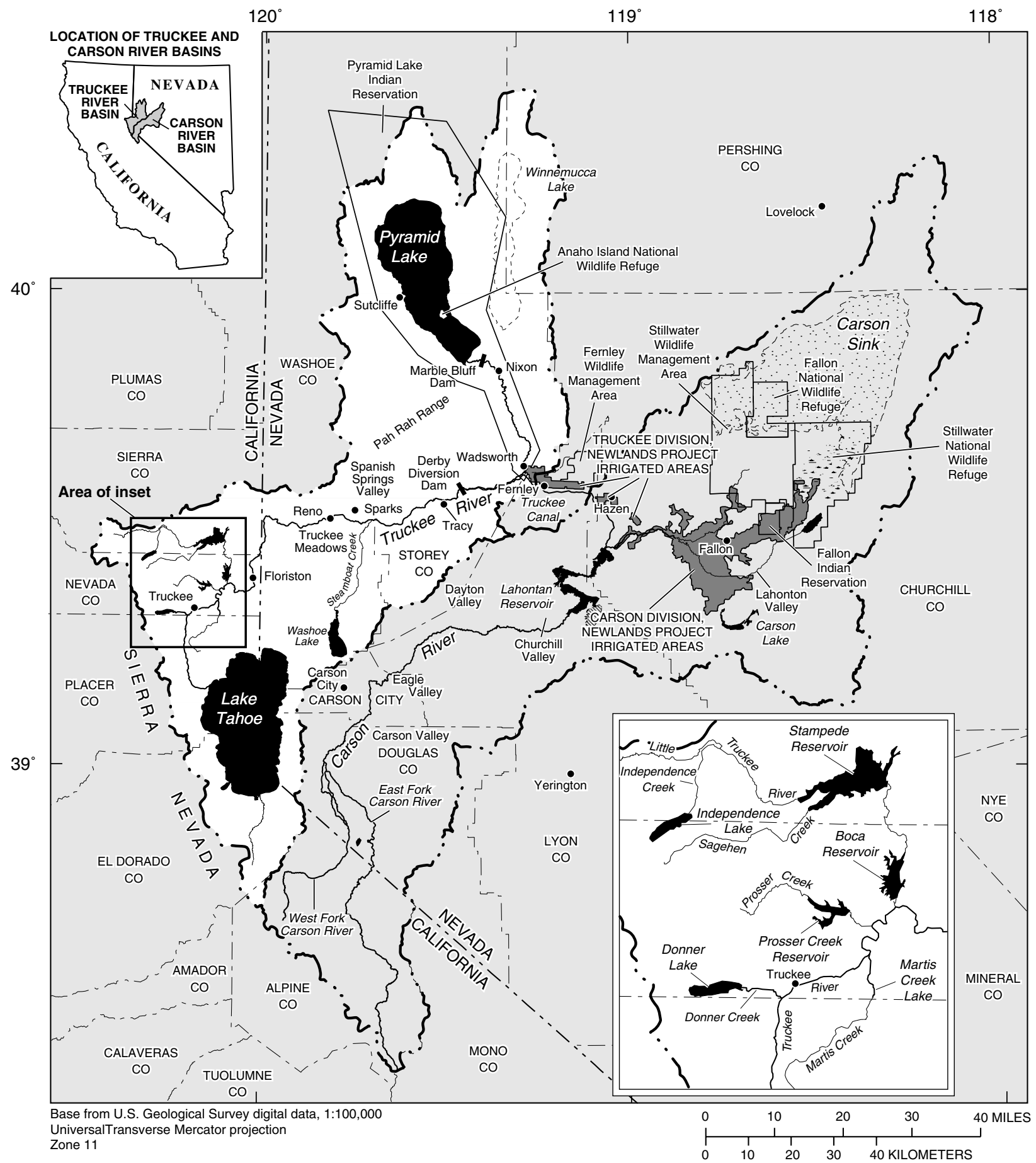

EXPLANATION

$-\cdots-$ Hydrographic basin boundary

Figure 1. Location of study area, California and Nevada 
water ${ }^{1}$ under the flexible and efficient policies proposed in the draft operating agreement being negotiated under Public Law 101-618. Such transactions may not be simulated in models where the flows are averaged out over an entire month and vice versa. Another source of potential differences in modeling results between monthly and daily models is the simulation of flood-control criteria at reservoirs, which are used to reduce the chances of downstream flooding. These criteria, by definition, establish daily constraints on reservoir storage levels. A sudden storm resulting in storages above an established rule curve would result in the subsequent release of that extra water on a daily basis, whereas a monthly model may allow that extra water to be stored. Similarly, credit storage cannot take place if daily flood-control criteria dictate that no reduction in a planned release can be made. There are many other examples, but the point is that, depending on the purpose and goals of the model user, the computation interval may be an important factor in selecting the most appropriate model.

The Truckee-Carson Program of the U.S. Geological Survey (USGS) was established by the Department of the Interior to support implementation of Public Law 101-618 by (1) compiling records from multiagency gaging stations into a consistent longterm data base to provide reliable data in support of modeling activities in the Truckee River and Carson River Basins, (2) establishing new streamflow and water-quality gaging stations for more complete waterresources information and more consistent support of river operations, and (3) developing a modeling system to support efficient water-resources planning, management, and allocation. Modeling activities within the USGS Truckee-Carson Program include the following.

- Flow-routing models of all or selected parts of the Truckee River and Carson Rivers, major tributaries, lakes/reservoirs, and the Truckee Canal.

\footnotetext{
${ }^{1}$ Under provisions proposed in the February 1998 draft TROA, credit water would be created, in part, when water of specific ownership is stored by reducing releases from a given reservoir. It can also be created by storing privately owned water and then transferring that water to credit water. Once created, credit water stored in individual Truckee River reservoirs would be allowed to be exchanged with storage in other Truckee River reservoirs and used as prescribed in the draft operating agreement (see exchange and transfer in the Glossary).
}

- Precipitation-runoff models for the headwater source areas of both basins.

- Stream temperature and total dissolved-solids models of the Truckee River.

- Operation models that simulate lake/reservoir and river operations, including the Truckee Canal, for both basins.

\section{Purpose and Scope}

The purpose of this report is to describe (1) the chronology and background of legal decrees and agreements that affect Truckee River operational practices; (2) the construction of the Truckee River Basin daily operations model, including the flow-routing model and data required to simulate operations; (3) the simulation of Truckee River Basin operations, both current $\left(1998^{2}\right)$ and proposed as of February 1998 under the draft TROA and WQSA; (4) a comparison of simulated and observed operations; and (5) limitations and suggested improvements of the model.

The daily operations model simulates flow and operations for three options: (1) current (1998) operational practices, (2) current operations and those proposed in draft TROA and WQSA, and (3) WQSA without draft TROA, which is not described separately in this report. TROA operations, as considered in this model documentation, reflect operational rules and policies presented in the February 1998 draft TROA, evaluated in the Draft Environmental Impact Statement/Environmental Impact Report by the Bureau of Reclamation and others (1998), and will be referred to hereafter as draft TROA. The geographic extent of the model is the Truckee River Basin from Lake Tahoe to Pyramid Lake, the Truckee Canal, and Lahontan Reservoir in the Carson River Basin (fig. 1). The operations model simulates both reservoir operations-for Tahoe, Donner, Martis Creek, and Independence Lakes, and Prosser, Stampede, and Boca Reservoirs in the Truckee River Basin and for Lahontan Reservoir in the Carson River Basin-and river operations including diversion of water from the Truckee River for irrigation and municipal and industrial uses, as well as diversion at Derby Diversion Dam of Truckee River water to the Newlands Project via the Truckee Canal.

\footnotetext{
${ }^{2}$ As used in this report, "current" refers to 1998.
} 
This report documents the first Truckee River operations model to simulate current and proposed (draft TROA) operations using a daily computation interval. Certain operational procedures, either historically practiced or proposed, are not included in the river/reservoir operational logic for simulation, nor are they described in this report. The historically practiced operations not included in the model are not typical of normal daily operations and were often single-incident variances based on human decisions, special permits, or court decisions. Proposed operational procedures not included were being negotiated and were, therefore, uncertain. The river/reservoir operational logic presented for purposes of simulation is based on the authors' best understanding of current regulations, decrees, and agreements. The authors' interpretation should not be considered a substitute for definition by more appropriate administrative or legal authorities.

The rules governing operations for the Truckee River are complex and unique. A general overview of Truckee River daily operations is provided in this report. Supplemental documentation to this report consists of detailed flowcharts and model code, which contains extensive internal documentation. The flowcharts provide a diagrammatic representation of the logical sequence of the code. The model code contains the most detailed information on the logic used to simulate river/reservoir operations. A listing of variable names used in the operations model code and their definitions also is available to assist users of either the flowchart or model code in the understanding and use of the model. ${ }^{3}$

The USGS Truckee River Basin operations model was designed to provide simulations that allow comparison of the effects of alternative management practices or allocations on streamflow or reservoir storages in the Truckee River Basin over long periods of time. Because the model was not intended to reproduce historical values, a traditional calibration with statistical comparisons of observed and simulated values is not particularly insightful for this model and database. This model is complex, contains extensive detail, and has a daily computation interval. Depending on the length of the desired period of simulation and computer

\footnotetext{
${ }^{3}$ The flowchart, code, and variable listings are not included in this report because of their length and technical complexity. Interested readers can contact the USGS Nevada District Public Information Assistant at (775) 887-7649 to obtain information on how to procure electronic copies of the variable listing, model code, or flowcharts.
}

hardware capabilities unique to each user, run times may require from several minutes up to several hours. Although some simple changes to certain variables (dates, target flows or storages, and so forth) could be implemented by almost anyone, it would require months of training to become familiar enough with the programs in the modeling system to be able to implement major changes in the model code. As such, this first version of the model was not designed for use in making quick simulations of near-term operations that might aid day-to-day water-resource management decisions. Significant modifications would be required to transform the model for that purpose. To accommodate a quick response to new simulation criteria, a Truckee River operations model would have to compromise detail for simplicity.

\section{Previous Investigations}

Horton (1997a) compiled a pre-20th-century and 20th-century chronological history of the Truckee River. Significant events were discussed back to the time before European and United States colonization.

Many investigators have designed and constructed models to simulate the physical and operational characteristics of the Truckee River. The Desert Research Institute at University of Nevada, Reno, developed a model that simulated Truckee River flow using historical and reconstructed monthly streamflow data (Butcher and others, 1969). The Truckee River was divided into regulated upstream reaches; a reach through the Truckee Meadows; a reach from Vista, Nev., to Nixon, Nev. (including the Truckee Canal); and a reach representing Pyramid Lake. The model incorporated a monthly mass balance that transmitted flows and accounted for gains and losses through each reach. Fordham and Butcher (1970) and Fordham (1972) combined a flow model with an optimization routine to maximize the beneficial use of surface water. This model was expanded to include both the Truckee and Carson River Basins. Chiatovich and Fordham (1979) combined a water-quality model developed by Westphal and others (1974) with a model of monthly reservoir operations to simulate an optimum operating policy. This combined model represents the water stored in all reservoirs in the upper Truckee River Basin, other than Lake Tahoe, as one combined reservoir, and it was developed to maximize the beneficial 
use of surface water by considering both downstream water rights and diversion policies as well as concentrations of constituents affecting water quality.

The Bureau of Reclamation (BOR) constructed a monthly mass-balance model to analyze both operation of reservoirs and allocation of water within the Truckee and Carson River Basins. The original BOR model was later modified by consultants for Sierra Pacific Power Company (SPPC) (Sierra Pacific Power Company, purveyor of water to municipal and industrial users in the Truckee Meadows) to include water-management alternatives discussed in the Preliminary Settlement Agreement (PSA) as modified by the Ratification Agreement (Pyramid Lake Paiute Tribe of Indians and SPPC, 1989). This agreement, between SPPC and the Pyramid Lake Paiute Tribe, provides for water storage for the Truckee Meadows during drought and for augmentation and modification of flow in the lower Truckee River during nondrought periods to improve spawning conditions for endangered and threatened fish species. The modified BOR model, referred to as the Negotiations Model, is not intended to simulate historical streamflow, but to make relative comparisons of the effects of alternative management practices on flows and allocations. The Negotiations Model is currently being used to examine the effects of operation and allocation changes addressed in P.L. 101-618 as well as other water management alternatives.

Cobb and others (1990) reviewed the BOR model and the Negotiations Model, both of which lacked formal documentation. The two models focused on the Truckee River system, and to a lesser degree, the Truckee Canal and the Carson River from Churchill Valley to Lahontan Valley. Both models are monthly mass-balance accounting-type models, as opposed to physically based flow-routing models. Both models use synthesized monthly average streamflow at various points in the Truckee-Carson River system. The data bases are composites of historical records and, when no historical records existed, estimated records. Both models (1) use streamflow and runoff data as input, (2) impose a complex set of legal constraints, operating criteria, and assumptions for effects of development on water use and surface-water/ground-water relations, and (3) incorporate an accounting procedure to simulate monthly average streamflow at several locations in the system.

Yardas (1996) developed a model of the Carson River below Lahontan Reservoir to simulate streamflow and distribution of irrigation water in the New- lands Project. The Yardas model can be used as a tool to better understand the effects of water acquisitions and other variables on inter- and intra-basin water demands and supplies.

In 1992, the USGS began to develop analytical modeling tools to help evaluate management options in support of the U.S. Department of the Interior implementation of P.L. 101-618. Berris (1996) developed a physically based flow-routing model of the Truckee River. The model routed daily mean streamflow along 114 miles (mi) of the mainstem Truckee River from just downstream from Lake Tahoe, Calif., to just upstream from Pyramid Lake, Nev. Hess (1996) developed a similar flow-routing model for the Carson River from the gaging station at East Fork Carson River near Markleeville, Calif., (italicized words are formal names for data-collection sites) and the gaging station at West Fork Carson River at Woodfords, Calif., to the gaging station Carson River at Fort Churchill, Nev., just upstream from Lahontan Reservoir. Selected reservoir and river operations added to the Truckee and Carson River flow-routing models are described by Berris and others (1996) and Hess (1997), respectively.

\section{Acknowledgments}

The authors gratefully acknowledge the support of many people and agencies who provided data or information used in this report. William D. Bettenberg and Jeffrey P. Zippin of U.S. Department of the Interior and Steven R. Alcorn, Minerals Management Service/Truckee-Carson Coordination Office provided the information, advice, and support necessary to construct and document the Truckee River Basin daily operations model. Thomas R. Scott, Al Olson, Bill Greer, and David Overvold of BOR, Roderick Hall of Sierra Hydrotech Consultants, Richard Moser of Sierra Pacific Power Company, John Sarna of California Division of Water Resources, Thomas Strekal of Bureau of Indian Affairs/Truckee-Carson Coordination Office, Chester Buchanan of the U.S. Fish and Wildlife Service, and several people in the office of the U.S. District Court Water Master, also called the Federal Water Master (FWM), notably Garry D. Stone, Jeff Boyer, Chad Blanchard, and Matthew Setty, provided insight into the complexities and operation of the Truckee River Basin through extensive interviews and written documentation. 


\section{DESCRIPTION OF STUDY AREA}

This section describes the Truckee River, Carson River, and Truckee Canal as an overview that precedes a more detailed discussion on the Truckee River Basin. Truckee River operations include diversion of water at Derby Diversion Dam into the Truckee Canal, a transbasin canal that delivers water to benchlands in the Truckee division of the Newlands Project and to Lahontan Reservoir in the Carson River Basin for use in the Carson Division of the Newlands Project (fig. 1).

The Truckee River originates at the outlet of the dam at Lake Tahoe in the Sierra Nevada of California and flows eastward into a topographically closed desert lake in Nevada (fig. 1). Its headwaters, where altitudes exceed 10,000 feet (ft) above sea level, flow into Tahoe - a mountain lake with a surface area of about 192 square miles $\left(\mathrm{mi}^{2}\right)$ and an average depth of about 990 $\mathrm{ft}$ (Jones and others, 1991a, p. 11). The terminus of the Truckee River is at Pyramid Lake-located in the Basin and Range Physiographic Province of western Nevada. Pyramid Lake is a sink, about $3,800 \mathrm{ft}$ in altitude, where water cannot leave through a surfacewater outlet. Drainage area for the entire Truckee River Basin is about $3,120 \mathrm{mi}^{2}$, but only about $1,430 \mathrm{mi}^{2}$ contribute to the 114-mi length of the Truckee River mainstem between the outlet of Tahoe and Marble Bluff Dam, located about 3.5 mi upstream from its mouth at Pyramid Lake (fig. 1; Brown and others, 1986, p. 81 and 125).

The Carson River also has its headwaters in the Sierra Nevada in California, just to the south of and adjacent to the Truckee River Basin, and flows generally to the northeast into a topographically closed desert sink in Nevada (fig. 1). Its headwaters, where altitudes also exceed 10,000 ft above sea level, are divided into the East and West forks. The East and West Forks of the Carson River flow north out of the Sierra Nevada to join in the broad Carson Valley in Nevada, where the altitude is approximately $4,700 \mathrm{ft}$. The river then flows to the northeast through Carson Valley and parts of Eagle, Dayton, and Churchill Valleys into Lahontan Reservoir-a manmade reservoir with a capacity of 317,300 acre-feet (acre-ft) with flashboards and 295,500 acre-ft without flashboards (table 1) (U.S. Geological Survey, 1998, p. 177; Thomas R. Scott, Bureau of Reclamation, oral commun., 1997). From that reservoir, the regulated lower river continues northeastward through the Newlands Project in Lahontan Valley and ultimately terminates in the vast Carson Sink (fig. 1), about 3,850 ft in altitude, where water cannot leave through a surface-water outlet. Drainage area for the entire Carson River Basin is about $3,966 \mathrm{mi}^{2}$, but only about $1,799 \mathrm{mi}^{2}$ contribute to the 152-mi length of the Carson River between the source of the East Fork Carson River (the longest of the two major forks of the Carson River) and Lahontan Dam, not including drainage area to the Truckee Canal outside of the Carson River Basin (Horton, 1997b, p. I-1 and U.S. Geological Survey, 1996, p. 184). This report describes reservoir operations and the operations model for only a small part (Lahontan Reservoir) of the Carson River Basin.

Most demands for water in both Truckee and Carson River Basins are from the Basin and Range Physiographic Province of western Nevada, whereas most precipitation that supplies water to these rivers falls within the Sierra Nevada of California. Additionally, most of the regulated water storage in the basins lies within the Truckee River Basin in the Sierra Nevada of California. There is little upstream storage in the headwaters of the Carson River Basin. The Truckee Canal provides an interbasin transfer of water to supplement the Carson River supply and to partially meet the large demand for irrigation water within the Newlands Project, the first Federal reclamation project in the United States. Construction of Derby Diversion Dam (hereafter referred to as Derby Dam) and the Truckee Canal began in 1903, and the project was operational in 1915 with the completion of Lahontan Dam in the Carson River Basin. Derby Dam, about 25 mi downstream from Reno, diverts water from the Truckee River to the Truckee Canal for delivery to the Newlands Project. The 32-mi manmade Truckee Canal has a maximum capacity of about 1,100 cubic feet per second $\left(\mathrm{ft}^{3} / \mathrm{s}\right)$ and a normal operating capacity of about $900 \mathrm{ft}^{3} / \mathrm{s}$ (Horton, 1997a, p. I-25 and I-48). Some of the diverted water carried by the canal provides water for current irrigation of about 3,500 acres of farmland within the Truckee Division of the Newlands Project near Fernley, Nev. The remainder of the water diverted to the canal is stored in Lahontan Reservoir for irrigation of about 56,500 acres in the Carson Division of the Newlands Project in the Carson River Basin near Fallon, Nev. (Alan Olson, Bureau of Reclamation, written commun., 1999).

For discussion in this report, the Truckee River Basin - from Lake Tahoe to Pyramid Lake-is divided into three hydrologic subunits-Lake Tahoe and the upper Truckee River, the middle Truckee River, and 
Table 1. Selected characteristics of major reservoirs

[Abbreviations: SPPC, Sierra Pacific Power Company, TCID, Truckee-Carson Irrigation District; USCOE, U.S. Army Corps of Engineers; BOR, U.S. Bureau of Reclamation; WCWCD, Washoe County Water Conservation District]

\begin{tabular}{|c|c|c|c|c|c|}
\hline Reservoir name & Dam owner ${ }^{1}$ & Dam operator ${ }^{1}$ & $\begin{array}{l}\text { Storage capacity } 1 \\
\text { (acre-feet) }\end{array}$ & $\begin{array}{c}\text { Dam } \\
\text { construction } \\
\text { date }^{1}\end{array}$ & $\begin{array}{l}\text { Drainage area }{ }^{1} \\
\text { (square miles) }\end{array}$ \\
\hline Lake Tahoe & SPPC & TCID & 744,600 & 1913 & 506 \\
\hline Donner Lake & SPPC/TCID & SPPC & 9,500 & ${ }^{2} 1928$ & 14 \\
\hline Martis Creek Lake & USCOE & USCOE & ${ }^{3} 20,400$ & 1971 & 40 \\
\hline Prosser Creek Reservoir & BOR & BOR & 29,800 & 1962 & 50 \\
\hline Independence Lake & SPPC & SPPC & 17,500 & 1939 & 8 \\
\hline Stampede Reservoir & BOR & BOR & 226,500 & 1970 & 136 \\
\hline Boca Reservoir & BOR & WCWCD & 40,900 & ${ }^{4} 1938$ & 172 \\
\hline Lahontan Reservoir & ${ }^{5} \mathrm{BOR}$ & ${ }^{5} \mathrm{TCID}$ & $\begin{array}{r}6,{ }^{7} 295,500 \\
7,{ }^{9} 17,300\end{array}$ & ${ }^{7} 1915$ & $7,8_{1,799}$ \\
\hline
\end{tabular}

\footnotetext{
${ }^{1}$ From Jones, 1991a, p. 11 except as noted.

${ }^{2}$ From U.S. Geological Survey, 1998, p. 318.

${ }^{3}$ From Bureau of Reclamation and others, 1998, hydrology appendix, p. H-2.

${ }^{4}$ From U.S. Geological Survey, 1998, p. 338.

${ }^{5}$ From Jones, 1996b, p. 26.

${ }^{6}$ At spillway crest.

${ }^{7}$ From U.S. Geological Survey, 1998, p. 176.

${ }^{8}$ Does not include drainage area from Truckee Canal.

${ }^{9}$ With use of flashboards on the spillway crest.
}

the lower Truckee River including Pyramid Lake-on the basis of similarity in climate and streamflow characteristics, physiography, human activities, and water quality (fig. 2). The boundaries of these subunits generally conform to published hydrographic boundaries for consistency with previous work (Berris, 1996, and Brown and others, 1986).

\section{Lake Tahoe and Upper Truckee River Subunit}

The Lake Tahoe and upper Truckee River subunit consists of the 932- $\mathrm{mi}^{2}$ drainage area of the Truckee River upstream from the USGS gaging station Truckee River at Farad, Calif. (hereafter referred to as Farad gaging station), located near the California-Nevada State line (fig. 2 and pl. 1). This subunit includes the drainage area and surface of the lake, and the drainage area of the Truckee River between the outlet of the lake and the Farad gaging station. It is a combination of subunits previously described in Brown and others (1986) and Berris (1996): the 506-mi ${ }^{2}$ Lake Tahoe subunit, which includes the drainage area and $192-\mathrm{mi}^{2}$ surface of the lake, and the 426- $\mathrm{mi}^{2}$ upper Truckee River subunit, which includes the drainage area of the Truckee River between the outlet of the lake and the Farad gaging station. Mean annual runoff at the Farad gaging station for water years $1909-97$ is 554,500 acre-ft (U.S.
Geological Survey, 1998, p. 344). The section of the Truckee River between the lake and the Farad gaging station is $34 \mathrm{mi}$ long.

The mountainous Lake Tahoe and upper Truckee River subunit is the coldest and wettest part of the study area. The Sierra Nevada, with peaks ranging from 8,000 to $10,000 \mathrm{ft}$ in altitude in this subunit, is a major barrier to moist air from the Pacific Ocean. The average annual precipitation for this subunit ranges from about 30 to 70 inches per year (in/yr,) mostly as snow from November through April (Jones and others, 1991a, p. 31). This mountain barrier causes a distinct rainshadow to the east. Thus, an average of only about $12-16 \mathrm{in} / \mathrm{yr}$ of precipitation falls in the drier parts of the subunit at lower elevations near the Nevada State line (Jones and others, 1991a, p. 31). Vegetation ranges from dense coniferous forests in the wet areas of the subunit to drier, open forests mixed with grasses, sagebrush, and rabbitbrush in the drier areas.

Runoff generated in the Lake Tahoe and upper Truckee River subunit supplies most of the water to the Truckee River system. Truckee River flows are heavily dependent on the yearly snowpack characteristics of the Sierra Nevada. High flows in the Truckee River are generally produced by snowmelt when temperatures increase in the spring or early summer, or in direct 


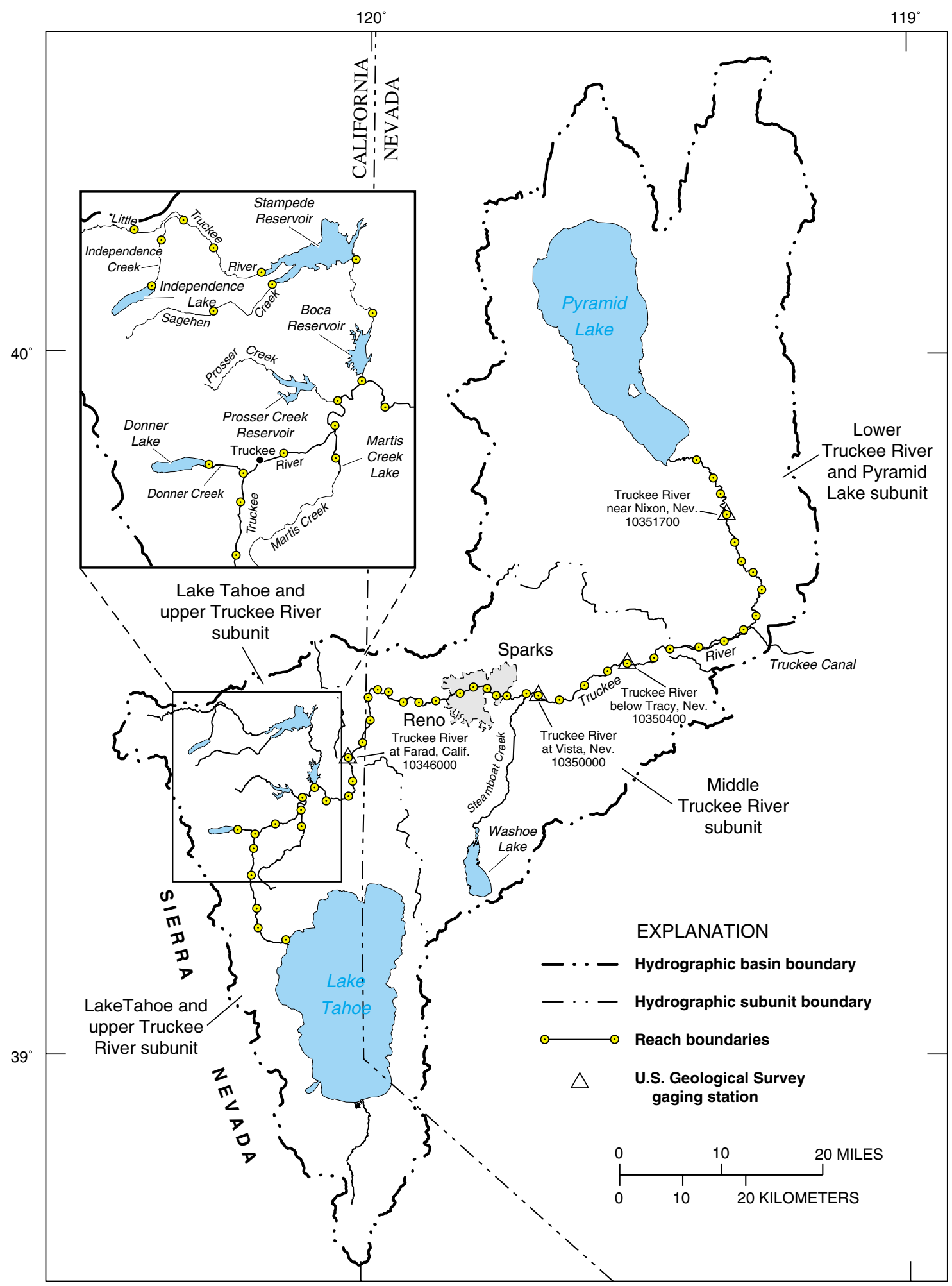

Base from U.S. Geological Survey digital data, 1:100,000, 1979-80 Universal Transverse Mercator projection, Zone 11

Figure 2. Hydrologic features, river reaches, and hydrologic subunits of the Truckee River Basin 
response to warm rains, derived from subtropical air masses, falling on winter snowpacks. When the relatively warm rains fall on large snowpacks, rain in addition to large amounts of water from melting snowpacks act together to form large runoff events or even floods. In contrast, during late summer and fall after the snowpack has melted, there is little water entering the Truckee River and, as a consequence, low flows commonly result.

Seven dams are operated upstream from the Farad gaging station to minimize flood hazards and to augment the water supply during periods of low flow and high demand. A small dam regulates the upper $6.1 \mathrm{ft}$ of Lake Tahoe, the largest storage facility in the system. The other dams - at Donner, Martis Creek, and Independence Lakes-and Prosser, Stampede, and Boca Reservoirs were built on four tributary streams. Selected characteristics of the major reservoirs in the Truckee River Basin, in addition to Lahontan Reservoir in the Carson River Basin, are summarized in table 1. These reservoirs are operated according to complex legal decrees and agreements that specify conditions for the storage and release of water. The regulations that govern reservoir operations, described later in this report and in the supplemental documentation, form an integral part of the operations model.

Urban and agricultural development is not extensive in the Lake Tahoe and upper Truckee River subunit and requires a small percentage of the available surface water. Most of the urban areas are around the lake and around the town of Truckee. The year-round permanent population around the lake is estimated at about 50,000 , but tourism increases daily population by as much as double the permanent population (Jones and others, 1991a, p. 37). Adjacent to the lake in California, municipal water use from both ground water and surface water was estimated to be between 15,000 and 17,000 acre-ft per year in 1992 (John Sarna, California Department of Water Resources, written commun., 1997; Jones and others, 1991a, p. 76). Water diverted for use in areas adjacent to the lake in Nevada was estimated at 6,600 acre-ft per year in 1995 (Jim Crompton, U.S. Geological Survey, written commun., 1999). Because of concerns about lake clarity and other lake water quality issues, municipal effluent is sewered and exported from the basin to sites in the Truckee and Carson River Basins. Small communities centered around and including the town of Truckee, Calif., use about 5,000-6,000 acre-ft/yr, primarily from ground water (Jones and others, 1991a, p. 76). Some small water systems serve the ski resorts located between the town of Truckee and the lake. Use of water for snowmaking has been about 1,000 acre-ft/yr, but will probably increase (Jones and others, 1991a, p. 84). Since 1980, effluent from the area around Truckee and the ski resorts, along with effluent from the north and west sides of the lake, receives tertiary treatment at the Truckee-Tahoe Sanitation Agency Water Reclamation Plant near the mouth of Martis Creek and is discharged into a leach field. From the leach field, the effluent percolates to ground water and may indirectly contribute to flows in both Martis Creek and the Truckee River after an estimated detention period of 3 to 6 months (Brown and others, 1986).

Developed agricultural land is negligible in this subunit because of the short growing season in the mountainous terrain. Water diverted from the Little Truckee River upstream from Stampede Reservoir for irrigation in California outside of the Truckee River Basin averaged about 5,900 acre-ft/yr for the period 1959-97 (Ron Vanscoy, California Department of Water Resources, oral commun., 1997). Fish and wildlife uses are non-consumptive, but threshold streamflows, called instream flows, have been established to provide viable habitat in this and all of the Truckee River subunits. In another non-consumptive use, water is temporarily diverted from the Truckee River near Floriston, Calif., close to the California-Nevada State line, transported by a wooden flume to a riverside powerplant, and returned to the river after passing through penstocks and rotating turbines for power generation.

\section{Middle Truckee River Subunit}

The Middle Truckee River subunit consists of the 744- $\mathrm{mi}^{2}$ drainage area to the Truckee River between the Farad gaging station and Derby Dam (fig. 2 and pl. 1). The section of the Truckee River contained in this subunit is about $46 \mathrm{mi}$ long. Mean annual runoff at the USGS gaging station Truckee River below Tracy, Nev. (hereafter referred to as Tracy gaging station; fig. 2 and pl. 1), about 5 mi upstream from Derby Dam, for water years 1972-96 was 580,900 acre-ft (U.S. Geological Survey, 1997, p. 399). Many tributary streams and the seven major upstream reservoirs provide and regulate flow that reaches this subunit, and from this flow, large volumes of water are diverted for power generation, irrigation, and municipal and industrial water supply. This subunit has about 26 diversions, but not all may be in operation every day or even every year. 
Although the middle Truckee River subunit is mostly in the drier Basin and Range Physiographic Province, the extreme southwestern part of this subunit consists of high mountain uplands. The precipitation in this subunit ranges from about 30 to $50 \mathrm{in} / \mathrm{yr}$ in the southwestern uplands to less than $8 \mathrm{in} / \mathrm{yr}$ in the Truckee Meadows and along the Truckee River corridor downstream (east) from the Truckee Meadows (Jones and others, 1991a, p. 31 and Hardman, 1965). The mountainous southwestern part of this subunit receives ample snowfall to provide perennial flows to small tributary streams. Flow from these small tributaries, directly as surface water or indirectly through irrigation systems, joins the Truckee River upstream from the USGS gaging station Truckee River at Vista, Nev. (hereafter referred to as Vista gaging station; fig. 2 and pl. 1). Downstream from this gaging station, the drainage consists of arid terrain and all tributary streams are ephemeral.

Wooden flumes carry diverted water for power generation to three power plants between the Farad gaging station and Reno, Nev. Like the diversion for power generation in the upper Truckee River subunit, the water returns to the river after passing through powerplants. Water also is diverted to a thermal powerplant for cooling purposes at Tracy, Nev. (fig. 1 and pl. 1), between the Vista gaging station and Derby Dam.

Water not consumed by evaporation at the powerplant was, until recently, discharged to holding ponds, where it was later re-used or allowed to percolate into the river alluvium. Currently, the small amount of water diverted for cooling purposes is consumed by evaporation within the powerplant.

Urban and agricultural land use is extensive throughout the middle Truckee River subunit. The cities of Reno and Sparks, along with their adjacent valleys, make up the Truckee Meadows in Nevadathe most populous area of the Truckee River Basin. Urban and suburban developments in this rapidly growing area have replaced large areas that had been devoted to agriculture. Rapid population growth in the Truckee Meadows has created a large municipal demand for the available supply of Truckee River water. The cities of Reno and Sparks, with a combined population of about 187,000 people in 1990 , had a growth rate of about 32 percent from 1980 through 1990 (Jones and others, 1991a, p. 40). As a consequence, the increasing water demands of the growing number of municipal and industrial users have largely been met by the acquisition and conversion of water rights previously used for irrigation. Highland Ditch, a ditch that used to supply water to irrigate agricultural areas only, now conveys a part of its flow to the municipal water-treatment plant at Chalk Bluff (pl. 1). Delivery of Truckee River water by Sierra Pacific Power Company (SPPC) to its Truckee Meadows municipal and industrial users was 41,440 acre-ft in 1980 and 54,209 acre-ft in 1987, an increase of about 31 percent. SPPC is the sole purveyor of water to municipal and industrial users in the Truckee Meadows. Despite increased population growth, annual water deliveries of Truckee River water to these users have exceeded those of 1987 for only two years-1996 and 1997. Municipal water-use restrictions have been necessary to level demands in accordance with treatment capacities during periods of heavy use during the summer. Thus, in 1992, a year of extreme drought, delivery of Truckee River water to municipal and industrial users was 42,960 acre-ft; during the high runoff years of 1996 and 1997, deliveries were 55,490 and 63,550 acre-ft, respectively (Richard D. Moser, Sierra Pacific Power Company, written commun., 1998).

Water for municipal and industrial (M\&I) use is currently treated at two locations, the Chalk Bluff and Glendale treatment plants (pl. 1). Water is supplied to the Chalk Bluff plant from Highland Ditch (near Verdi, Nev.) or from the pumping station near Orr Ditch close to the plant site. The Glendale facility diverts water from the Truckee River at a pumping station at the plant. The Chalk Bluff water-treatment plant went into service in April 1994, to replace the Idlewild, Hunter Creek, and Highland water treatment plants, which were removed from water-treatment service in March 1994, September 1995, and May 1996, respectively (Richard D. Moser, Sierra Pacific Power Company, oral commun., 1997). About half of the M\&I water distributed is consumptively used. The other half (wastewater from M\&I uses) is returned through a sewage collection system to the Truckee Meadows Water Reclamation Facility (TMWRF), previously known as the Reno-Sparks Sewage Treatment Plant. The treated effluent is then discharged into Steamboat Creek near its confluence with the Truckee River near Vista, Nev.

In the middle Truckee River subunit, Truckee River water is diverted to agricultural lands, primarily devoted to pasture and alfalfa in the outlying areas of the Truckee Meadows as well as along the Truckee River corridor to the east. The diverted water flows through intricate networks of lateral ditches and fields. Excess water not infiltrated to deep ground water or 
consumed by evapotranspiration (ET) may return to the river either (1) through drains or ditch returns at discrete locations, (2) by surface flow over wide areas where fields are adjacent to the river, or (3) by groundwater accretions. Drains typically intercept water applied to fields that either runs off the surface or infiltrates to shallow ground water. If diverted water is never applied to fields, such as stockwater or excess diverted water, it may return directly to the river through that same ditch or indirectly through tributaries to the river. Agricultural water also may return to the river along fields immediately adjacent to the river. This water may run off the field at several locations or it may infiltrate to shallow ground water that subsequently may discharge along the river. Although agricultural returns may enter the river at several locations in the Truckee Meadows, most enter the Truckee River through North Truckee Drain from the north and Steamboat Creek from the south. These two major drainages also intercept urban runoff from the RenoSparks area. Steamboat Creek also receives runoff from tributary streams with headwaters in the high mountains southwest of the Truckee Meadowssuch as Galena, Whites, and Thomas Creeks (pl. 1). Downstream from the Truckee Meadows, local diversions carry water for irrigation of benchlands adjacent to the river. Agricultural water used on these benchlands returns to the river at scattered locations, and is frequently ungaged.

At Derby Dam, the downstream boundary of the middle Truckee River subunit, a significant percentage of the total river flow may be diverted to the Truckee Canal for delivery to Newlands Project irrigators along the canal and in the Carson River Basin near Fallon, Nev. (fig. 1). From 1973-96, the average annual diversion from the Truckee River to the Truckee Canal to supply the Newlands Project was about 166,000 acre$\mathrm{ft} / \mathrm{yr}$, or about 29 percent of the annual average runoff at the Tracy gaging station (U.S. Geological Survey, 1974-75, 1976-97). In years when Carson River runoff is below average, however, higher percentages of Truckee River flow are diverted, typically more than 80 percent (U.S. Geological Survey, 1989-93). For example, in 1990, about 87 percent of the annual streamflow measured at the Tracy gaging station was diverted to the Truckee Canal (U.S. Geological Survey, 1991, p. 271, 274). However, adjustments to the 1988 Operating Criteria and Procedure (OCAP) were implemented in December 1997 that will reduce diversions to an average of about 90,000 acre-ft/yr.
Some of the water diverted into the Truckee Canal is spilled back to the Truckee River at the Gilpin Spill, located about 7.5 miles downstream from the canal headgates. Truckee-Carson Irrigation District (TCID) uses the spill to re-regulate or fine-tune diversions to the Newlands Project. The exact amount of the spill can vary significantly in time and has never been gaged.

\section{Lower Truckee River and Pyramid Lake Subunit}

The lower Truckee River and Pyramid Lake subunit consists of the $1,440-\mathrm{mi}^{2}$ drainage area that includes the Truckee River downstream from Derby Dam, Pyramid Lake, and a topographically closed basin that includes a dry lake bed, known as Winnemucca Lake (fig. 1). This subunit is a combination of subunits previously described in Brown and others (1986) and Berris (1996): the 261- $\mathrm{mi}^{2}$ lower Truckee River subunit, which includes the drainage area of the mainstem Truckee River between Derby Dam and Marble Bluff Dam (about 3.5 mi upstream from Pyramid Lake; pl. 1), and the 1,180-mi ${ }^{2}$ Pyramid Lake subunit downstream from Marble Bluff Dam. The Truckee River between Derby Dam and Marble Bluff Dam is about $34 \mathrm{mi}$ long. Mean annual runoff for water years 1958-97 at the USGS gaging station Truckee River near Nixon, Nev. (hereafter referred to as Nixon gaging station; fig. 2 and pl. 1), about 9.5 mi upstream from Marble Bluff Dam, is 398,700 acre-ft (U.S. Geological Survey, 1998, p. 388). Downstream from Derby Dam, the Truckee River flows east to Wadsworth, Nev., and then north to Marble Bluff Dam. Prior to the 1930's, the Truckee River split just upstream from the present site of Marble Bluff Dam, and the river flowed into either Pyramid Lake or Winnemucca Lake or both. Since diversions to the Newlands Project began at Derby Dam in 1905, average flow of the river diminished sufficiently to result in declines of the water levels in both lakes. By the early 1930's, only Pyramid Lake received inflows from the river, and by 1938 Winnemucca Lake went dry (Brown and others, 1986, p. 20). The Truckee River currently enters Pyramid Lake across a broad delta downstream from Marble Bluff Dam. The interface of the delta and the lake shoreline is migratory, depending on lake levels and the volume of flow from the Truckee River. This interface has shifted several miles during this century because of the varying lake levels. To provide a stable 
reference point for modeling and measurements, Marble Bluff Dam was chosen as the boundary between the lower Truckee River and Pyramid Lake subunits previously described in Brown and others (1986) and Berris (1996).

In the lower Truckee River and Pyramid Lake subunit, the Truckee River flows through arid desert terrain. Annual precipitation in this subunit ranges from about $16 \mathrm{in} / \mathrm{yr}$ in the northwest along the crest of the Pah Rah Range (fig. 1) to less than 8 in/yr along the Truckee River corridor (Hardman, 1965). As a result of the arid climate, tributaries of the Truckee River flow only intermittently. Therefore, when large amounts of water are diverted from the middle Truckee River subunit to the Truckee Canal, flows in the lower Truckee River can be reduced appreciably. Other than from ephemeral tributaries, inflows to the lower section of the river are from Gilpin Spill from the Truckee Canal and from ground-water discharge from the Fernley area, some of which may originate from seepage from the Truckee Canal (Van Denburgh and Arteaga, 1985, p. 10-11).

Water is diverted from the river at 10 locations to irrigate land along the river corridor in the lower Truckee River and Pyramid Lake subunit. There currently are no power-generation or municipal and industrial diversions in the reach. Irrigation water may return to the river either as surface inflows through ditches, return drains, or along fields adjacent to the river, or as ground-water discharge.

As the Truckee River turns northward near Wadsworth, Nev., it enters the Pyramid Lake Indian Reservation. The reservation, created in 1859 by the Secretary of the Interior, follows the Truckee River corridor to Pyramid Lake and includes the entire lake and adjacent area. Within the reservation, water is diverted from the Truckee River to cultivate lands along the river corridor and adjacent benchlands.

Reduced flow in the Truckee River downstream from Derby Dam since diversion of water from the Truckee River to the Newlands Project began caused a decline of water level in Pyramid Lake, the formation of a broad shallow river delta at Pyramid Lake, and periodic shallow water levels in the lower Truckee River. The reduced lake and river levels have hindered the ability of fish species to migrate upstream to spawn in the Truckee River. From the late 1800's to September 30, 1997, Pyramid Lake levels declined from about $3,870 \mathrm{ft}$ above sea level to $3,808 \mathrm{ft}$, a net decline of about $62 \mathrm{ft}$. In response to the 1967 listing of the
Pyramid Lake cui-ui lakesucker as an endangered species, the Bureau of Reclamation developed Operating Criteria and Procedures (OCAP) to maximize use of Carson River, substantially reducing diversions of Truckee River water to the Newlands Project. Partially as a result of OCAP, since the lowest level of $3,783.9 \mathrm{ft}$ was measured at Pyramid Lake in 1967, Pyramid Lake levels have increased about $24.5 \mathrm{ft}$ to $3,808.4 \mathrm{ft}$ on September 30, 1997 (U.S. Geological Survey, 1998, p. 237). Water in the lower Truckee River is currently managed for the benefit of the endangered cui-ui lakesucker species and to facilitate the establishment of cottonwood trees to improve riparian canopy and fish habitat. Fish are important to the culture and economy of the Pyramid Lake Indian Reservation. The Pyramid Lake Paiute Tribe and the United States are attempting to secure more water and more water rights to conserve the cui-ui as well as the Lahontan cutthroat trout, a threatened species of fish that has been reintroduced to the lake since the original strain became extinct in the lake more than 50 years ago.

The level of Pyramid Lake also is important to wildlife. Anaho Island National Wildlife Refuge, located within Pyramid Lake and the Indian reservation, is home to a colony of American white pelicans. At very low lake levels, a land bridge from the shore to Anaho Island forms allowing predators access to the nesting area (Jones and others, 1991a, p. 85).

Marble Bluff Dam was built in 1975 to help reestablish certain fish species in Pyramid Lake and the Truckee River. A fishway leading from the dam to the lake allows some of the fish to migrate to fish-handling facilities at the dam where fish can be captured and eggs stripped for hatchery production, or fish can be bypassed upriver for spawning. Recovering cui-ui lakesucker and Lahontan cutthroat trout require more than just minimal Truckee River streamflows. Several interactive physical and chemical characteristics of the river-such as volume, timing, and temperature of flows during the spawning season and the volume/ quality of Pyramid Lake water-affect the productivity and viability of these fish. 


\section{CHRONOLOGY AND BACKGROUND OF DECREES, AGREEMENTS, AND LAWS AFFECTING OPERATIONS}

Current and proposed operational practices are the result of a long history of construction and management of facilities used to regulate Truckee River water. The following sections, based on selected parts of the draft TROA environmental impact statement/environmental impact report (EIS/EIR), describe the chronology and background of the facilities that regulate Truckee River water and the rules and policies that govern their operations (Bureau of Reclamation and others, 1998).

\section{Early History}

The first facility to control the waters of the Truckee River for beneficial use was a private dam constructed at the outlet of Lake Tahoe in the late 1800's. That dam initiated a series of disputes over rights to the use of the waters of the lake and the Truckee River. The dam was used primarily to regulate flows in the Truckee River so that logs could be floated to sawmills in the town of Truckee, Calif. In 1902, the predecessor to Sierra Pacific Power Company (SPPC), the Truckee River General Electric Company (Electric Company), obtained title to the dam. Several small runof-the-river hydropower plants were also constructed on the Truckee River in California and Nevada around the turn of the century.

After Congress authorized construction of the Newlands Project in 1902, the Bureau of Reclamation (BOR) began construction of Derby Dam on the lower Truckee River and construction of the Truckee Canal. Derby Dam was completed in 1905, and the Truckee Canal was completed in 1906. In 1903, BOR made claim to rights to the water stored in Lake Tahoe for delivery to the Newlands Project. Following a series of negotiations, the Federal Government was granted an easement over Lake Tahoe Dam, which allowed for more reliable water deliveries to the Newlands Project. As part of these negotiations, the original "Floriston rates" were established in 1908 , providing the first required instream flow criteria for the river.

The original Floriston rates established a minimum flow in the river of $500 \mathrm{ft}^{3} / \mathrm{s}$ from March through September and $400 \mathrm{ft}^{3} / \mathrm{s}$ for the remainder of the year, as long as water was available in Lake Tahoe for release to the river. Floriston rates were intended to provide sufficient streamflow for a pulp and paper mill near Floriston, Calif., and for operation of the hydropower plants, as well as to supply water for other Truckee River rights holders.

In 1913, BOR and the Truckee River General Electric Company reconstructed the original dam at Lake Tahoe to its current configuration that controls the top 6.1 feet of storage at the lake.

\section{Truckee River General Electric Decree}

Negotiations and litigation between BOR and the Truckee River General Electric Company (United States of America v. Truckee River General Electric Company) continued and involved property owners at Lake Tahoe who were concerned over property damage due to high lake water elevation. The disputes resulted in a 1915 Federal court decree known as the Truckee River General Electric Decree, which gave the United States an easement and the right to operate Lake Tahoe Dam and its controlling works. The easement and the right to operate the dam were subject to the requirement, among others, that sufficient water be released to maintain Floriston rates, as defined in 1908. The decree set forth the operating constraints of the lake and granted BOR the right to use Lake Tahoe Dam to regulate streamflows for diversion to the Newlands Project. It did not, however, resolve concerns of the property owners.

\section{Truckee River Agreement}

Drought situations in the late 1920's and early 1930's resulted in extensive controversy among BOR, irrigators (both in the Newlands Project and in the Truckee Meadows area), and landowners at Lake Tahoe over water rights, low lake water elevation, and attempts to pump water from the lake to satisfy downstream water users. Negotiations resulted in the Truckee River Agreement of 1935. Parties to the agreement were the Federal Government, Sierra Pacific Power Company (SPPC), Truckee-Carson Irrigation District (TCID) $)^{4}$, and Washoe County Water Conservation District. Key points of the Truckee River Agreement include:

- Confirming and modifying the original 1908 Floriston rates (table 2). The modified rates are still

\footnotetext{
${ }^{4}$ Quasi-municipal agency that is the contract operator for BOR of the Newlands Project and operator of Derby and Lahontan Dams, and Lake Tahoe.
} 
Table 2. Floriston rates as related to Lake Tahoe water-surface elevation and month ${ }^{1}$

\begin{tabular}{|c|c|c|c|c|}
\hline \multirow[b]{2}{*}{$\begin{array}{l}\text { Water-surface elevation at Lake Tahoe Dam } \\
\text { (feet, Lake Tahoe datum) }\end{array}$} & \multicolumn{4}{|c|}{$\begin{array}{l}\text { Floriston rates: Flow at gaging station, Truckee River at Farad } \\
\text { Calif. (10346000), in cubic feet per second }\end{array}$} \\
\hline & October & November-February & March & April-September \\
\hline Below 6,225.25 & 400 & 300 & 300 & 500 \\
\hline Between $6,225.25$ and 6,226 & 400 & 350 & 350 & 500 \\
\hline Above 6,226 & 400 & 400 & 500 & 500 \\
\hline
\end{tabular}

${ }^{1}$ Based on Bureau of Reclamation and others (1998, table 1-1, p. 1-7)

in effect today. The rates were modified to supply M\&I and irrigation demands, as well as to provide flows for hydropower generation. Under the agreement, the modified Floriston rates are met using unregulated streamflow and releases from Lake Tahoe (and, when it was later built, Boca Reservoir). As shown in table 2, the modified Floriston rates vary from 300 to $500 \mathrm{ft}^{3} / \mathrm{s}$ at Farad, Calif., depending on the water-surface elevation of the lake and the month of the year. Hereafter, the term "Floriston rates" will refer only to modified Floriston rates.

- Providing operating criteria to prevent damage along the shoreline of Lake Tahoe from highwater. The operating criteria provide for release of water from the lake to prevent the water surface from exceeding $6,229.1 \mathrm{ft}$, as much as practicable.

- Defining interrelationships among SPPC's privately owned water, natural (unstored) flow, and diverted flow as they pertain to the Newlands Project, the Washoe County Water Conservation District, and SPPC.

- Defining future water-storage facilities called pondage used for the purpose of regulating the flow of the Truckee River for the periods (1) April 1 to October 31 when Floriston rates are not exceeded, and (2) November 1 to March 31 to the extent necessary in the operation of the Truckee River hydroelectric plants.

- Providing for construction of a new Federal dam for a "supplemental reservoir" (later named Boca Reservoir), allocating the water right priority for filling the reservoir, and establishing operating criteria for the reservoir to satisfy the exercise of water rights by supplementing Floriston rates.
- Establishing conditions under which Lake Tahoe could be pumped.

\section{Construction of Additional Storage Reservoirs in the 1930's}

During the 1930's, additional water storage was developed to further control flows in the Truckee River system. The Donner Lake Company expanded Donner Lake Dam in 1929 to create 9,500 acre-ft of storage in the lake. The dam was later acquired by SPPC and TCID in 1943. In 1939, SPPC acquired Independence Lake and Dam and enlarged the dam to increase the lake's usable storage capacity from 3,000 to 17,500 acre-ft. Water stored in these reservoirs is considered privately owned water. SPPC water in the lake is released to satisfy the exercise of SPPC water rights. TCID's water in Donner Lake, when released and diverted from the Truckee River to the Truckee Canal at Derby Dam, is used generally to satisfy the exercise of individual water rights for irrigation in the Newlands Project. Independence Lake water is released to satisfy the exercise of SPPC water rights. Releases from these reservoirs are not currently used to achieve Floriston rates.

After Congress authorized the Truckee Storage Project in 1935, BOR began construction of Boca Dam on the Little Truckee River. The dam was completed in 1939. Releases from Boca Reservoir are used to achieve Floriston rates and to provide flood control. The dam is operated by the Washoe County Water Conservation District.

\section{Donner Lake Agreement}

The Donner Lake Agreement among TCID, SPPC, and the Donner Lake Company, signed in 1943, governs the operation of Donner Lake to satisfy 
the exercise of water rights of SPPC and Newlands Project. Withdrawals are limited during the summer recreation season.

\section{Orr Ditch Decree}

A 1944 Federal court decree, known as the Orr Ditch Decree, adjudicated the water rights of litigants in a 1913 suit filed by the United States (United States of America v. Orr Ditch Water Company) that sought to confirm water rights for use in the Newlands Project. The Orr Ditch Decree affirmed individual water rights - amount, place and type of use, and priorityand included guidelines previously specified in the Truckee River Agreement for operating Lake Tahoe and Boca Reservoir to serve those rights. Parties to the Orr Ditch Decree include the Federal Government, SPPC, TCID, the Washoe County Water Conservation District, and individual water rights holders in Nevada, many of them agricultural water users in the Truckee Meadows area.

Based on the date of establishment of the Pyramid Lake Indian Reservation, the court recognized an 1859 priority date for water rights for irrigation of reservation lands. Known as Claims 1 and 2, these are the most senior water rights on the Truckee River. The decree also incorporates a SPPC right for a continuous flow of $40 \mathrm{ft}^{3} / \mathrm{s}$ for M\&I demands in Reno, with a priority junior only to Claims 1 and 2 .

\section{Sierra Valley Decree}

As a result of litigation (United States of America v. Sierra Valley Water Company), the Sierra Valley Decree of 1958 confirmed a water right for Sierra Valley Water Company, which has historically diverted water out of the Little Truckee River to the Feather River Basin in California for irrigation ${ }^{5}$. The diversion averages about 6,000 acre-ft/yr. The Sierra Valley Settlement Agreement of 1993 settled a dispute concerning the point at which diversions from the Little Truckee River will cease as a result of the Sierra Valley Decree.

\footnotetext{
${ }^{5}$ Agricultural lands in the Feather River Basin that receive water from the Little Truckee River for irrigation are located in Sierra and Plumas Counties.
}

\section{Construction of Prosser Creek and Stampede Dams}

After Congress authorized the Washoe Project in 1958, BOR constructed Prosser Creek Dam on Prosser Creek. Prosser Creek Reservoir provides 29,800 acre$\mathrm{ft}$ of storage. Construction was completed in 1962. In accordance with the Tahoe-Prosser Exchange Agreement, a portion of water stored in the reservoir may be used to achieve Floriston rates in lieu of release from Lake Tahoe. Historically, water stored in the reservoir in excess of storage under the Tahoe-Prosser Exchange Agreement has been referred to as "uncommitted water" and is used to benefit Pyramid Lake fish.

Under the same congressional authorization, BOR completed construction of Stampede Dam and Reservoir on the Little Truckee River in 1970. Stampede Reservoir has a capacity of 226,500 acre-ft. Flood-control criteria require a combined maximum of 30,000 acre-ft of storage space in Stampede and Boca Reservoirs.

\section{Tahoe-Prosser Exchange Agreement}

The Tahoe-Prosser Exchange Agreement of 1959 provides additional criteria for operating Lake Tahoe and the facilities that became Prosser Creek Dam and Reservoir. The agreement is among BOR, SPPC, TCID, and the Washoe County Water Conservation District. The purpose of the Tahoe-Prosser Exchange Agreement is to maintain flows immediately downstream from the lake. During high runoff, releases from the lake for Floriston rates may be unnecessary. In such a case, unless the lake is spilling or being drawn down due to high lake level conditions, the flow in the Truckee River between the lake and Prosser Creek may be almost nil. Under these conditions, the Tahoe-Prosser Exchange Agreement allows water to be released from Lake Tahoe to sustain instream flows for fishes in the Truckee River between the lake and Prosser Creek in exchange for an equal amount of water to be stored in Prosser Creek Reservoir, if possible. This was the first agreement in the Truckee River Basin to exchange storage in one reservoir for storage in another reservoir to achieve multiple benefits.

\section{Endangered Species Act}

The Endangered Species Act (ESA) provides for the protection and conservation of plant and animal species designated by the Secretary (Secretary of the Interior) as "endangered" or "threatened." Cui-ui was 
listed as an endangered species in 1967. Lahontan cutthroat trout was initially listed as an endangered species in 1970, but was reclassified as threatened in 1975 .

\section{Stampede Reservoir Judgement}

As a result of litigation (Carson-Truckee Water Conservancy District v. Watt, 1982), a Federal court upheld a determination of the Secretary that his obligations under the ESA took precedence over his authority to contract for delivery of water for irrigation and M\&I uses. The judgement requires all storage in Stampede Reservoir to be used to provide water for the threatened and endangered Pyramid Lake fishes.

\section{Newlands Project Operating Criteria and Procedures}

Diversions to the Newlands Project from the Truckee River were generally unregulated prior to the implementation of Newlands Project Operating Criteria and Procedures (OCAP). OCAP were first introduced in 1967 with the objective to maximize the use of Carson River water for the Newlands Project and minimize the diversion of Truckee River water via the Truckee Canal. A more stringent OCAP that imposed a limit on Project diversions was approved in 1973 as a result of litigation (Pyramid Lake Paiute Tribe of Indians v. Morton, 1973) in which a Federal court ruled that the Newlands Project was diverting too much water from the Truckee River. Other OCAP's were implemented in 1988 and again in 1997 (Adjusted OCAP), which further control diversions from the Truckee River to the Newlands Project.

OCAP includes procedures for calculating the annual water demand of the Newlands Project and the diversions of Truckee River water to the Project. Major components of OCAP include provisions for a maximum annual diversion; implementation of conservation measures to improve project efficiency; and criteria for diverting Truckee River water to the Newlands Project based upon the forecasted Carson River supply for the Carson Division, Lahontan Reservoir storage objectives (table 3), seasonal Newlands Project demands, and current reservoir storage.

\section{Preliminary Settlement Agreement}

The PSA (Preliminary Settlement Agreement), entered into in 1989 by SPPC and the Pyramid Lake Tribe, is an agreement to change the operation of Federal reservoirs and the exercise of Truckee River water rights to (1) improve spawning conditions for the endangered and threatened Pyramid Lake fishes and (2) provide additional M\&I water for the Reno-Sparks area during drought periods. Many provisions of the PSA have not yet been implemented and will be implemented only through TROA.

The PSA allows SPPC to store a certain amount of privately owned water and a portion of former agricultural water rights in Federal reservoirs for M\&I drought relief. SPPC would obtain a priority right to store this water in Stampede Reservoir. In exchange, that portion of Floriston rate water required solely for hydropower generation by SPPC's Truckee River hydropower plants would be retained in storage and released at a later date for the benefit of the Pyramid Lake fishes. This water would be stored as credit water with varying degrees of protection against evaporation and spillage. Under certain conditions, some categories of credit water could be exchanged with other categories of stored water.

\section{Public Law 101-618}

Public Law 101-618 was enacted by Congress in 1990 to provide direction, authority, and mechanism for resolving disputes over water and water rights in the Truckee and Carson River Basins. The purposes of the mandatory and permissible actions as specified in section 202 of P.L. 101-618 are to:

- Provide for the equitable apportionment of the waters of the Truckee River, Carson River, and Lake Tahoe between the States of California and Nevada;

- Authorize modifications to the purposes and operations of certain Federal Reclamation project facilities to provide benefits to fish and wildlife; municipal, industrial, and irrigation users; and recreation;

- Authorize acquisition of water rights for fish and wildlife;

- Encourage settlement of litigations and claims;

- Fulfill Federal trust obligations toward Indian tribes;

- Fulfill the goals of the ESA by promoting the enhancement and recovery of the Pyramid Lake fishes; and 
Table 3. June through December end-of-month storage objectives for Lahontan Reservoir from 1988 and Adjusted Operating Criteria and Procedures (OCAP) ${ }^{1}$

\begin{tabular}{|c|c|c|c|}
\hline \multirow[b]{2}{*}{ Month } & \multicolumn{2}{|c|}{1988 OCAP } & \multirow{2}{*}{$\begin{array}{c}\text { Adjusted OCAP } \\
\begin{array}{c}\text { Storage objective } \\
\text { (acre-feet) }\end{array}\end{array}$} \\
\hline & $\begin{array}{l}\text { Lower storage objective } \\
\text { (acre-feet) }\end{array}$ & $\begin{array}{c}\text { Upper storage objective } \\
\text { (acre-feet) }\end{array}$ & \\
\hline June $^{1}$ & 215,000 & - & 190,000 \\
\hline July & 160,000 & 162,400 & 160,000 \\
\hline August & 140,000 & 142,200 & 100,000 \\
\hline September & 120,000 & 122,000 & 64,000 \\
\hline October & 80,000 & 81,500 & 52.000 \\
\hline November & 160,000 & 162,400 & 74,000 \\
\hline December & 210,000 & 213,600 & 101,000 \\
\hline
\end{tabular}

${ }^{1}$ Modified from Bureau of Reclamation and others (1998, table 1-2, p. 1-10). The end-of-month Lahontan storage objectives for January through June are variable, with a goal of achieving a storage at the end of June of 190,000 acre-feet or 215,000 acre-feet for Adjusted OCAP and 1988 OCAP, respectively. The 1988 OCAP was used from 1988 to 1997. Adjusted OCAP was implemented in December 1997.

${ }^{2}$ Storage objectives listed assume annual Carson Division demand of 271,000 acre-feet.

- Protect significant wetlands from further degradation and enhance the habitat of many species of wildlife that depend on those wetlands.

To achieve these purposes, P.L. 101-618 directs, among other actions, negotiation of an operating agreement (i.e., TROA). Provisions of the law directly related to the draft TROA are discussed below. (The following provisions were selected from a larger list in the EIS/EIR according to their pertinence to the simulation of operations.)

- Section 204 (Interstate Allocation) reaffirms the Alpine Decree for Carson River waters and apportions the waters of the Truckee River and Lake Tahoe between California and Nevada. TROA may include criteria and procedures for implementing and monitoring this apportionment, which automatically enters into effect when TROA is adopted, and certain other conditions of the act are satisfied. Once TROA goes into effect, the Interstate Allocation will provide a permanent and final resolution to long-standing controversies over the States' rights to these waters. If TROA does not go into effect, these allocations do not go into effect for the Carson River, the Truckee River, or Lake Tahoe.

- Subsection 205(b) authorizes the Secretary to use Washoe Project facilities, Truckee River Storage Project facilities, and Lake Tahoe Dam for the storage of nonproject water to fulfill the purposes of Title II of P.L. 101-618. This authorization forms the cornerstone of TROA. Allowing multiple use of Federal reservoirs may enhance the water supply available for the Sierra Pacific service area during drought situations and may also provide better control of streamflows for Pyramid Lake fishes. Subsection 205(b) also authorizes the Secretary to collect appropriate charges for such uses.

\section{Interim Storage Agreement}

As authorized under paragraph 205(b)(3) of P.L. 101-618, the Secretary, SPPC, the Washoe County Water Conservation District, and Pyramid Lake Tribe reached an agreement (Contract for Storage of Sierra Pacific Power Company Water in Stampede and Boca Reservoirs) in 1994 that allows SPPC to store additional water in Stampede and Boca Reservoirs. The agreement provides additional storage capacity for SPPC to meet domestic, municipal, and industrial needs in Truckee Meadows during drought situations. The initial term of the agreement is 25 years; however, it will be superseded by TROA and is, therefore, referred to as the interim storage agreement.

\section{Truckee River Water Quality Settlement Agreement}

The Water Quality Settlement Agreement (WQSA), signed in 1996, provides for acquisition of water rights to resolve major water quality problems in the Truckee River in Nevada, while simultaneously providing a major contribution to fish and wildlife 
resources of the Truckee River. Parties to the agreement are the Cities of Reno and Sparks, the Washoe County Water Conservation District, the Pyramid Lake Tribe, the U.S. Department of the Interior (Interior), the U.S. Department of Justice, the U.S. Environmental Protection Agency (EPA), and the Nevada Division of Environmental Protection (NDEP).

Key provisions (selected) and terms of the WQSA are as follows.

- Reno, Sparks, and Washoe County agree to provide $\$ 12$ million to acquire Truckee River water rights.

- Department of the Interior agrees to provide $\$ 12$ million to acquire Truckee River water rights.

- As provided by draft TROA, all water associated with the acquired water rights will be stored in a jointly managed pool in Federal reservoirs and released according to agreed-upon management measures and schedules to (1) augment instream flows in the Truckee River from Reno to Pyramid Lake, (2) improve Truckee River water quality, and (3) maintain and preserve the lower Truckee River and Pyramid Lake for fish, wildlife, and recreation.

- A water supply will be established to benefit water quality of the Truckee River downstream from TMWRF by using Truckee Meadows sewage effluent rather than Truckee River water for irrigation of certain Orr Ditch water rights; the Truckee River water that would have been diverted to satisfy the exercise of those Orr Ditch water rights will either be stored in upstream reservoirs or left in the river to provide this water quality benefit.

\section{CONSTRUCTION OF TRUCKEE RIVER BASIN OPERATIONS MODEL}

A daily operations model was constructed to simulate river and reservoir operations and streamflow for the Truckee River Basin from Lake Tahoe to Pyramid Lake, the Truckee Canal, and Lahontan Reservoir. This model was constructed within a larger modeling system that includes a database management program (ANNIE, Lumb and others, 1990) and a program that simulates river/reservoir operations and a variety of hydrologic processes (Hydrological Simulation Program-FORTRAN (HSPF), Bicknell and others, 1993).
The HSPF program is composed of a variety of modules that are used to simulate operations or such physical processes as streamflow-routing, stream temperature, precipitation-runoff, and water quality. Some of these HSPF modules can be used by themselves, but others must be used with one or more other modules. For example, the module used to simulate streamflow routing can be used by itself. The simulation of operations by HSPF, however, requires the use of a flow-routing module and an operations module within HSPF. Models are unique applications of generic programs such as HSPF. Once data and parameters unique to a particular basin are specified or input to the program, a model results that cannot be used in another river or basin.

The modeling system uses the time-series data management program ANNIE. ANNIE is an interactive program designed for management of data, which includes file creation, data set management, data analysis, and data display. ANNIE is used for the storage and management of the daily time-series data required to simulate various processes within a hydrologic system. HSPF simulation modules draw input from and write output to binary, direct-access files called Watershed Data Management (WDM) files.

The complex operational rules and data requirements of the comprehensive river-basin model described in this report require advanced computerprocessing capabilities to facilitate the creation of new scenarios and for summarizing and analyzing large volumes of input and output data. An interactive computer program, GENSCN (GENeration and analysis of model simulation SCeNarios), developed by Kittle and others (1998), can be used in conjunction with the operations model described in this report. GENSCN was developed to create simulation scenarios, analyze results of the scenarios, and compare scenarios. A variety of standard tabular, graphical, and statistical tools are provided, including animation. Readers interested in further details on the GENSCN program are referred to the documentation for that program.

The following sections describe (1) the HSPF program that contains flow-routing and operations modules, (2) the flow-routing and operations modules within HSPF to simulate daily streamflow, and (3) the data used by the daily model to simulate flow routing and operations. 


\section{Description of Hydrological Simulation Program-FORTRAN}

HSPF is a computer program that can simulate hydrologic and associated water-quality processes on pervious and impervious land surfaces, within the soil profile, and in drainage networks and well-mixed lakes and reservoirs (Bicknell and others, 1993). Recently, logical capabilities were added to HSPF to allow the simulation of reservoir and river operations (Thomas Jobes, Aqua Terra Consultants, written commun., 1998). HSPF was chosen to simulate Truckee River operations primarily because it can (1) simulate continuous, long periods of time, including periods of storm runoff and low flows, (2) simulate at a daily time interval, (3) simulate the hydraulics of complex natural and manmade drainage networks, (4) produce simulation results for many locations along a river and its tributaries, (5) simulate reservoir and river operations, and (6) compute a detailed water budget that accounts for inflows and diversions as well as different categories of water in the river and associated reservoirs. HSPF is an internationally used non-proprietary program maintained by the Environmental Protection Agency.

A category of water is any parcel of water that is individually accounted for in an observed or simulated water budget. A single river, reservoir, lake, or diversion ditch may contain several categories. Water within a category may have specific ownership, such as "privately owned stored water," or have a designated use, such as "pooled water" (used to meet a minimum-flow requirement known as Floriston rates).

The user's control input (UCI) file contains information the user must provide to run functional modules within HSPF. Modules describe discrete physical processes that may be added to the UCI. The UCI provides instructions to HSPF by defining the required modules to simulate a particular modular objective, such as streamflow routing. The Truckee River Basin operations model contains modules describing flow routing and operations. The flowrouting module determines the conveyance and storage characteristics for the stream channels and reservoirs, whereas the operations module is structured to allow development of rules that simulate human decisions and control over inflows and outflows to the hydrologic network. The HSPF operations module for the Truckee River must be run in combination with the HSPF daily flow-routing module developed by Berris (1996).
The modules in HSPF include one or more "blocks" that group the computations needed by each module. The streamflow-routing module uses only one block, the RCHRES (reach-reservoir) block. The module used in simulating operations contains two blocks, the SPECIAL ACTIONS (SPECL) block and the CATEGORY block. As previously stated, both modules, and therefore all three blocks, are required to fully simulate operations using HSPF. The SPECL block contains the model code that simulates river and reservoir operations. The code developed for the Truckee River Basin operations model in the SPECL block was further subdivided for organizational clarity into "subblocks," which usually deal with specific reservoir or river operational functions such as flood-control criteria, minimum instream flows, and so forth.

The RCHRES block of HSPF can simulate streamflow for long periods of time by numerically representing inflow, outflow, and the hydraulics of channels, reservoirs, and lakes. Channel inflow and outflow may be simulated in HSPF or provided to HSPF by external time series. Channel inflow is routed as streamflow through the drainage network by a modified kinematic-wave algorithm that is a component of HSPF. The drainage network may include any natural or manmade flow-conveyance system, but hydraulic properties of individual reaches must be held constant. Water lost from the drainage network is represented by evaporation, channel outflow as seepage to ground water, or discharge (diversion) out of the modeled drainage network.

The SPECL and CATEGORY blocks of HSPF can simulate reservoir and river operations over long periods of time by the designation of water categories in the CATEGORY BLOCK and model code in the SPECL block (Thomas Jobes, Aqua Terra Consultants, written commun., 1998). The separation of water into specific categories is handled by defining water categories in the CATEGORY block of the UCI file. Each category has a "tag" that is used throughout the UCI as a method to specify ownership of a given water quantity. Reservoir and river operations are governed by complex rules in legal agreements, decrees, and regulations that specify logical conditions for the use of water categories in the SPECL block. Variables are used in the code of the SPECL block to store numerical values necessary in the simulation processes that evaluate these logical conditions. Accordingly, if certain conditions are met during a simulation, then certain actions are taken. The Truckee River Basin operations model 
simulates reservoir and river operations by evaluating these conditions and executing the appropriate operations in the model code. Conditions that are typically evaluated during simulations include the time of year; reservoir stage, reservoir storage, or volume of a given water category in a reservoir; streamflow magnitude; and fulfillment of water demands. Thus, for example, release from the Lake Tahoe category pooled water to satisfy Floriston rates could be programmed to occur if the date is from April 1 through October 31 of a given year, if the elevation of the lake is within the range $6,223.0$ to $6,225.5 \mathrm{ft}$, and if the demand for additional water at the Farad gaging station has not been met.

HSPF simulates operations and streamflow using a computational time interval of one day. Within each time interval, the operations are simulated in the SPECL block, then the results are input to the RCHRES block where flow routing is simulated. For the first time interval of a model run, the model evaluates initial conditions, simulates operations accordingly, and inputs the results to the RCHRES block for flow routing. For each following time interval, conditions of flow and reservoir storage existing after the final calculations for the previous time interval are the same as the conditions at the beginning of the next time interval. Based on the evaluation of these conditions, the model simulates operations, and, again, inputs the results to the RCHRES block for flow routing. Because inflows are simulated within the RCHRES block, the inflows and reservoir storages evaluated for the simulation of operations in a time interval are from the flow routing results of the previous time interval. Using this method of simulation provides operational decisions at the beginning of a computational time interval based on the inflows and storages from the previous time interval. This is not unlike actual operations, in which the runoff for a particular day is unknown at the beginning of the day, dictating the use of the previous day's inflow to guide current operations, instead of a perfect forecast.

The previous discussion provided a general overview of the features of the method HSPF uses to route streamflow and perform operations. The following discussion on the HSPF flow-routing module provides description of (1) the HSPF drainage network segments called reaches, (2) the HSPF parameters used to characterize reaches, (3) how reach outlets allow delivery of water to specific destinations, such as a downstream reach or a diversion ditch, and (4) how HSPF routes streamflow from reach to reach in a drainage network.
HSPF requires that the linked network of river channels, lakes, and reservoirs be divided into segments called reaches. A reach must have relatively uniform hydraulic properties. For this study, hydraulic properties were generalized for reach segmentation to simulate only the essential properties that determine streamflow and volume in the drainage network. It was not necessary to simulate streamflow through every pool, riffle, or diversion dam.

HSPF model parameters in the RCHRES block represent hydraulic properties of all designated reaches in a drainage network. Function tables of the RCHRES block, referred to as $\mathbf{F}$-tables, contain relations between hydraulic properties of channel reaches, lakes, and reservoirs. The hydraulic properties of channels, which include channel shape, channel roughness, channel slope, and channel length, determine the relation of streamflow to the volume of water stored in a reach. Ftables for unregulated channel reaches contain the relation between the two parameters streamflow at the downstream end of a reach and volume of water contained in a channel reach. Water volume in storage and corresponding streamflow are the parameters that define how water is routed through a channel from a reach to a downstream reach. F-tables for lakes and reservoirs contain the relations between three parameters-depth, surface area, and volume. These relations for lakes and reservoirs determine the depth, surface area, and volume of water in storage at the end of a simulated time interval after all inflows (for example, inflows from upstream reaches, tributaries, or precipitation) and all outflows (for example, regulated releases, diversions, or evaporation) have been simulated.

A reach can have up to five outlets in HSPF.

HSPF can produce simulation results for each outlet of a given reach. Typically, a reach outlet represents the downstream boundary of a reach and enables delivery of water from that reach to the next downstream reach. Reach outlets also allow diversion of water from a reach to ditches or canals, or seepage of water from river or lake bed to ground water. When water is diverted from a reach to a ditch or canal, that ditch or canal may or may not be a part of the modeled drainage network. If the ditch or canal is a part of the modeled drainage network, flow can be routed through reaches defined for that ditch or canal system. If the ditch or canal is not a part of the modeled drainage network, the water diverted from a given reach is not routed through the ditch or canal and is simply lost from the network. 
HSPF can route flow through a drainage network, from reach to reach, to the designated downstream boundary of a drainage basin. A water budget is determined for the total volume of water as well as each water category in each reach by accounting for total volume of water and volume of water categories entering a reach, total volume of water and volume of water categories stored in a reach, and total volume of water and volume of water categories leaving a reach during a given time interval. The total volume of water entering a reach over a given time interval is the sum of the volumes from all inflows of all water categories during that interval. Inflows to a reach consist of all connected upstream reaches, tributaries, precipitation, and runoff and ground water from contributing subbasin areas that drain to the reach. In turn, the total water stored in a reach in a given interval is the sum of all volumes of all water categories draining into the reach from all connected reaches and drainage areas, plus the initial volume stored in the reach, minus the volume discharged from the reach during the time interval. The total volume of water leaving a reach over a given time interval is the sum of the volumes from all outflow of all categories during that interval.

In HSPF, outlet discharge from a reach is a function of volume, a function of time, or a combination of both functions of volume and time. When outlet discharge is a function of volume, the total volume of water in the reach determines the outlet discharge as specified by model parameters. The volume function is most useful when a stage-discharge relation can characterize outlet discharge. When outlet discharge is a function of volume, water categories typically discharge from a reach in proportion to their stored volume within that reach. When outlet discharge is a function of time, an external or internally generated time series governs the outlet discharge for specific water categories. The time function is useful when a control structure governs outlet discharge, such as regulated releases from a reservoir or regulated diversions to meet agricultural or municipal and industrial demands. For example, model code within the SPECL block may internally generate a time series of Lake Tahoe releases from specific categories to meet Floriston rates, the minimum-flow requirement measured at the downstream Farad gaging station. The numerical value generated by the model code for a simulated time interval will govern the simulated release from specific lake water categories for that time interval as a function of time. When a reach has more than one outlet, then the priority of outflow demands for each outlet can be specified.

Water volumes may change categories when discharged from a reach. For example, uncommitted water from Prosser Creek Reservoir will change to fish water upon release. These and other categories are defined in a later section, "Current Water Categories."

\section{Flow-Routing Model}

The Truckee River flow-routing model is a necessary module for the operations model. The flowrouting module characterizes the movement of water into and through the reaches of the drainage network while the operations module simulates the manmade regulation of water movement within and out of the drainage network. The HSPF operations module for the Truckee River must be run in combination with the HSPF daily-flow routing module.

Berris (1996) developed a physically based flowrouting model constructed to simulate streamflow at daily time intervals along the Truckee River from the outlet of Lake Tahoe to just upstream from Pyramid Lake. Daily streamflow data for water years 1978-92 for the mainstem of the Truckee River, tributaries, irrigation ditches, and the Truckee Canal were obtained from several agencies and compiled into a comprehensive data base using WDM files. (A water year is the 12-month period beginning October 1 and ending September 30, and designated by the calendar year of the ending date.) Where streamflow data were unavailable or incomplete, flows were estimated. The Truckee River and two tributaries, Donner Creek and Martis Creek, were divided into 47 reaches, each with fairly uniform hydraulic characteristics. Hydraulic characteristics defined for the 47 reaches were based on crosssectional survey data obtained from field surveys and previous studies.

Model testing demonstrated that hydraulic characteristics of the Truckee River are adequately represented in the model (Berris, 1996) for a range of flow regimes. Most of the differences between observed and simulated streamflow resulted from inadequate data describing inflow to and outflow from the Truckee River, rather than from inadequate data characterizing the hydraulic properties of the reaches. Inflow and 
outflow data were considered inadequate for reaches where, and periods when, measurements were inaccurate or data were not available.

The scope of the flow-routing model described above was expanded from 47 reaches to 72 reaches for use with the operations model. The additional 25 reaches include 7 reaches defined for lakes and reservoirs in the Sierra Nevada (Lake Tahoe, Donner, Martis Creek, and Independence Lakes, and Prosser, Stampede, and Boca Reservoirs); 7 for channel segments along the Little Truckee River, and Independence and Sagehen Creeks; 1 for Pyramid Lake; 1 for Lahontan Reservoir in the Carson River Basin; and 9 for the Truckee Canal (fig. 3 and pl. 1).

The RCHRES block of HSPF routes streamflow along connected reaches of a drainage network based on the hydraulic characteristics of reaches (Berris, 1996). For channel reaches where outlet discharge is a function of volume, F-tables represent the relation of surface-water volume temporarily stored in the reach to surface-water discharge at the downstream end of the reach. Hydraulic properties, measured or estimated at cross sections, were used to determine volume-discharge relations for these types of reaches. Most reaches were characterized using at least 3 cross sections, but reaches in the Truckee Meadows were characterized using between 12 and 18 cross sections (Berris, 1996). Reach characteristics along the Truckee Canal were computed using only 1 cross section in some cases because of the fairly uniform channel geometry of the canal (Carol Grenier, Bureau of Reclamation, written commun., 1994). For lakes and reservoirs where outlet discharge from a reach is a function of time, F-tables represent the relations between depth, surface area, and volume. F-tables were based on hydraulic properties obtained from tables and graphs relating depth and volume, and tables and graphs relating depth and surface area for the following reservoirs: Lake Tahoe (A.M. Piper, U.S. Geological Survey, written commun., 1993); Donner and Independence Lakes (Sierra Pacific Power Company, written commun., 1980); Prosser Creek Reservoir (Bureau of Reclamation, written commun., 1962 and U.S. Army Corps of Engineers, 1985); Martis Creek Lake (U.S. Army Corps of Engineers, 1985); Boca Reservoir (Bureau of Reclamation, written commun., 1970 and 1980); Stampede Reservoir (Bureau of Reclamation, written commun., 1974 and 1980); Pyramid Lake (Harris, 1970); and Lahontan Reservoir (Alan Olson, Bureau of Reclamation, written commun., 1989).

\section{Data for Simulation of Streamflow and Operations}

Data necessary for streamflow and operations simulations are provided to the model either from external time series or from within the model code of the SPECL block. External time series are accessed directly by the model during simulations or can be accessed by the interactive programs ANNIE or GENSCN during pre- or post-simulation analyses. Data within the model code of the SPECL block are considered to be numerical assignments to model variables. Default values are provided, but the model user may modify the values to create different model scenarios through the use of the interactive computer program GENSCN or through any standard editor program. Descriptions and discussions of the many types and uses of data used for numerical assignments to model variables are provided in the two succeeding sections-"Description and Simulation of Current Operations" and "Description and Simulation of Draft TROA and WQSA Operations"- - and in the flowchart, code, and variable listings provided in the supplemental documentation that was described in the "Purpose and Scope" section.

In addition to data used for variable assignments within the SPECL block, the following types of external time series of daily data are required input to run the operations model for all or part of the period covering water years 1933 to $1997^{6}$.

- Streamflow data:

- Reservoir inflows:

- Lake Tahoe (net inflow);

- Donner Lake;

- Martis Creek Lake;

- Prosser Creek Reservoir;

- Independence Lake;

- Stampede Reservoir;

- Boca Reservoir.

- River inflows:

- Ungaged tributaries to the Truckee River upstream from Farad gaging station;

- Sagehen Creek;

- Dog Creek;

\footnotetext{
${ }^{6}$ The period of data, water years 1933-97, was chosen because a sufficient amount of observed data were available for use by the operations model. The period represents a wide range of hydrologic conditions.
} 
- Hunter Creek;

- Carson River near Fort Churchill.

- Tributaries and channel seepage losses between the Farad and Vista gaging stations other than Dog and Hunter Creeks.

- Evapotranspiration (ET) losses from phreatophytes downstream from Vista gaging station.

- Climate Data:

- Precipitation:

- Six major lakes and reservoirs upstream from Farad gaging station ${ }^{7}$ not including Lake Tahoe;

- Pyramid Lake;

- Truckee River precipitation from Vista gaging station to Marble Bluff Dam.

- Evaporation:

- Six major lakes and reservoir upstream; from Farad gaging station ${ }^{6}$ not including Lake Tahoe;

- Pyramid Lake;

- Truckee River evaporation from Vista gaging station to Marble Bluff Dam;

- M\&I demand data for the Truckee Meadows;

- Forecast Data:

- Lake Tahoe April-to-peak closed-gates rise;

- Little Truckee River above Boca Reservoir, Calif., April to July runoff.

- Truckee River at Farad, Calif., April to July runoff.

- Carson River at Fort Churchill, Nev., April to July runoff

- Runoff volume for each month from April through November as inflow to all seven major lakes and reservoirs upstream from Farad gaging station and intervening areas adjacent to the Truckee River between Lake Tahoe and Farad gaging station.

Forecast is based on snowpack condition on April 1 and median temperature and precipitation thereafter.

The following sections describe the data used by the operations model to route streamflow and to simulate operational practices in the Truckee River drainage network. Other sources of data can be used, so long as the model input requirements listed above are met. A more detailed description of the data used for simula-

\footnotetext{
${ }^{7}$ Donner, Martis Creek, and Independence Lakes, and Prosser, Stampede, and Boca Reservoirs.
}

tions by the operations model is provided by a separate report titled, "Hydrologic Data Used in the River and Reservoir Operations Model, 1933-97, Truckee River Basin, California and Nevada" (Berris and others, 2001).

\section{Streamflow}

Streamflow data are required as input to the USGS Truckee River Basin operations model at upstream model boundaries and at boundaries representing locations of tributary inflow upstream from the Vista gaging station. Upstream from the Farad gaging station, inflows are provided at model boundaries by three methods: (1) observed flow data from USGS gaging stations, (2) water balance computations, and (3) results from Precipitation-Runoff Modeling System (PRMS) simulations (Leavesley and others, 1983). Flow data measured at single gaging stations, when available, are used as direct input to channel reaches of the Little Truckee River upstream from Stampede Reservoir (reach 185), Sagehen Creek upstream from Stampede Reservoir (reach 198), and the Truckee River upstream from the Farad gaging station (reach 230). Where inflow data from single gaging stations are not available for direct input to the model, then net inflows are provided to model boundaries by water balance computations using data from two or more gaging stations. For Lake Tahoe, net inflows, which include streamflow gains, precipitation gains, and evaporation losses, are determined by water balance computations because accurate precipitation gains and evaporation losses are not available for model simulations. Water balance computations are also used to determine net inflows for the Truckee River between the lake and the town of Truckee (reaches 110-140) and Donner Creek between Donner Lake and the Truckee River (reach 149) during periods when reliable gaging station data are available (pl. 1). When and where reliable flow data from gaging stations are not available for direct input to model boundaries or for water-balance computations of net inflows, then results from PRMS simulations are provided as inflows. PRMS, a physically based, distributed-parameter watershed model, provides simulated daily inflows from 16 headwater subbasins to these model boundaries (Jeton, 2000).

Downstream from the Farad gaging station, inflows to the Truckee River from previously diverted water for agricultural and M\&I use are simulated (see the later sections "Truckee Meadows Diversions" and 


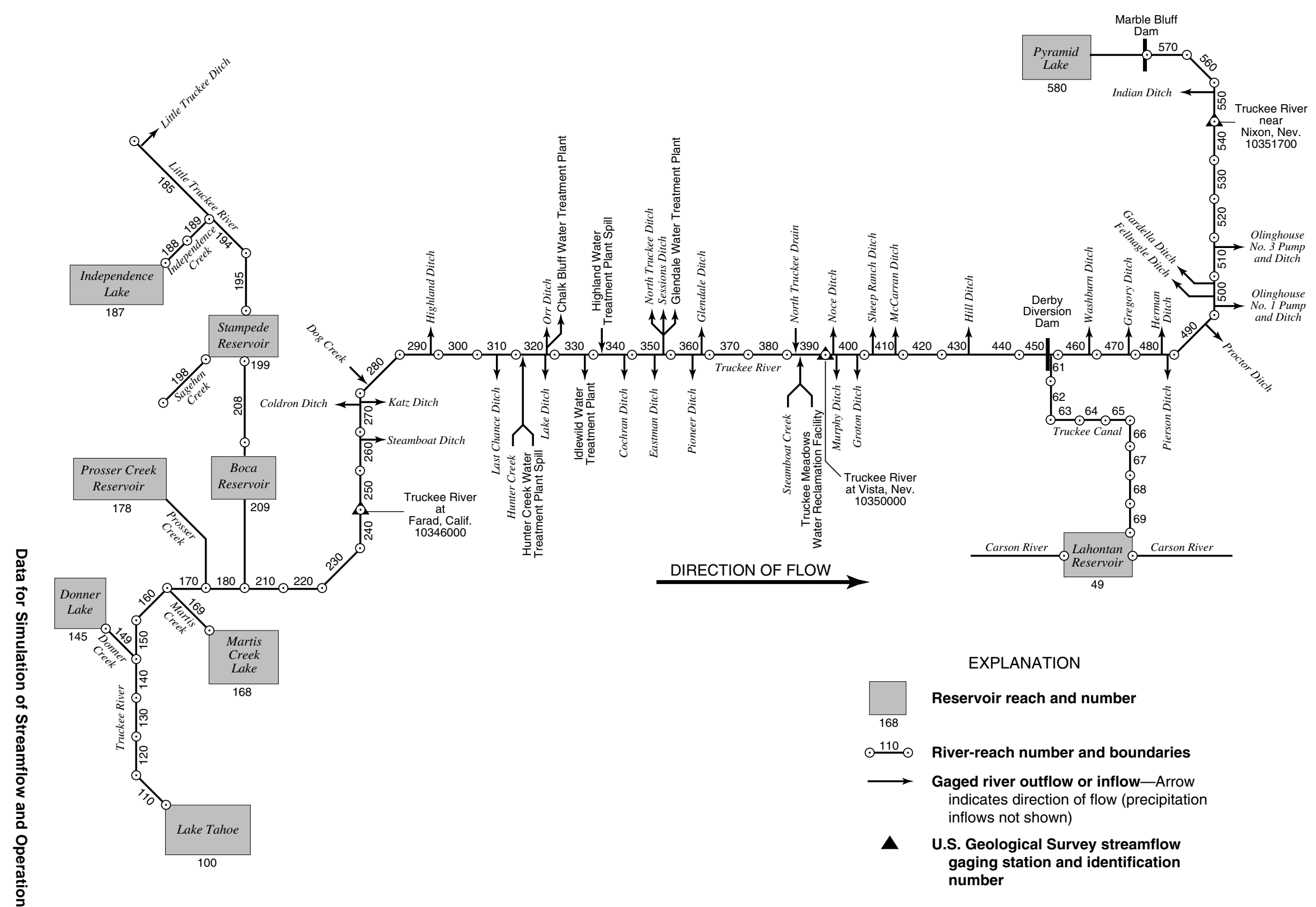

Figure 3. Schematic diagram showing the river and reservoir reaches, outflows, and inflows for the U.S. Geological Survey Truckee River Basin operations model 
"Lower Truckee River Diversions"). The flow returned to the river from previously diverted water for agricultural uses could only be crudely estimated because ungaged returns from a given ditch could not be related to nearby gaged returns from other ditches. Agricultural irrigation return flows were estimated by applying simple return coefficients to diverted flows (Jeff Boyer, U.S. District Court Water Master, oral commun., 1993). M\&I returns to the Truckee River were easier to estimate because they are measured at the Truckee Meadows Water Reclamation Facility. Simple return coefficients were determined for each month by comparing measured M\&I diversions to measured M\&I returns. M\&I return flows were estimated by applying these return coefficients to flows diverted for M\&I uses.

Time series containing estimates of tributary inflows or channel seepage losses for the reach between the Farad and Vista gaging stations also were estimated. Except for inflows from Dog Creek and Hunter Creek upstream from Reno, neither sufficient streamflow records from gaging stations nor detailed PRMS output were available to fulfill the need for gain/loss information for this reach of the Truckee River. Flow data measured at gaging stations, when available, or output from PRMS models provided daily inflows from Hunter Creek and Dog Creek. Except for inflows from these two basins, gains and losses for this reach of the river come from (1) water balance computation of net inflows (1981-92) or (2) regression analysis (1933-80, 1993-97). Truckee Meadows ungaged gains and losses (TMUGL) include all ground water inflows, tributary inflows, channel losses, and other gains except inflows from Dog and Hunter Creeks. TMUGL is computed as:

\section{TMUGL $=$}

Vista flow $-($ Farad + Dog Creek + Hunter Creek

flows) + net agricultural and M\&I diversions.

The daily values of TMUGL, which can contain both positive and negative values, are input upstream from inflows from the Truckee Meadows Water Reclamation Facility so that if the river "dries up" as a result of TMUGL, at least the treated sewage effluent flow volume will be present at the reach boundary representing the Vista gaging station.

Downstream from the Vista gaging station, all of the tributaries are ungaged and ephemeral. Tributary inflows for the Truckee River downstream from Vista and for the Truckee Canal do not normally supply large seasonal or annual volumes of water and therefore are not provided to the operations model.

\section{Evapotranspiration}

Time series of streamflow losses due to ET from phreatophytes were estimated (Berris, 1996). The time series were applied to the Truckee River downstream from the Vista gaging station. Upstream from Vista, streamflow losses were accounted for within the methods described above that provided inflows to and losses from the Truckee River. For the Truckee Canal, streamflow losses were accounted for by empirical methods and applied within the model code of the SPECL Block (Alan Olson, Bureau of Reclamation, written commun., 1996).

\section{Climate}

The operations model requires meteorologic data as precipitation and evaporation time series for simulation of reservoir and streamflow gains and losses. These time series were applied to lakes and reservoirs, except for Lake Tahoe, and to the Truckee River downstream from the Vista gaging station. Net inflows computed for Lake Tahoe include gains and losses from precipitation and evaporation. Upstream from Vista, gains to streamflow from precipitation and losses to streamflow from evaporation were accounted for within the methods described in the section above on streamflow data, that provided inflows to and losses from the Truckee River. For the Truckee Canal and Lahontan Reservoir, such gains and losses are accounted for by empirical methods and applied within the model code of the SPECL Block (Alan Olson, Bureau of Reclamation, written commun., 1996). A succeeding section, "Truckee River Diversions to Newlands Project," further describes the use of computed gains and losses.

Precipitation data applied to designated lake and reservoir reaches and channel reaches downstream from Vista were based on estimates or observed measurements obtained from National Weather Service climate stations, located in California, near Donner Memorial State Park (near Donner Lake), Truckee, Sagehen Creek, Boca Reservoir, and in Nevada, near Reno and Wadsworth. Estimates of daily precipitation data were necessary to extend the daily precipitation records at some of the above climate stations back to 
1933. Estimates were made by using a regional time series of daily precipitation data and computing the local time series of the appropriate climate stations listed above using statistical correlative methods (M.D. Dettinger, U.S. Geological Survey, written commun., 1997, and Dettinger and Cayan, 1996). Average monthly evaporation rates for lake and reservoir reaches and channel reaches were estimated (Roderick L. Hall, Sierra Hydrotech, written commun., 1994; P.H. McGauhey and others, 1963; and S.W. Hostetler, U.S. Geological Survey, oral commun., 1994).

\section{Municipal and Industrial Demands}

The operations model requires a time series of M\&I surface-water demand for the Truckee Meadows. M\&I demand is defined as the volume of water needed for the supply of a city, town or similar population groups for the purposes of commerce, trade, or industry. This time series contains estimated M\&I demand from surface-water sources in the Truckee Meadows based on observed M\&I demand data obtained from

Sierra Pacific Power Company for the index period of January 1995 through December 1995 (Richard D. Moser, Sierra Pacific Power Company, written commun., 1995). These estimates assume there is no variation of daily M\&I demand from year-to-year. For model simulations, a growth coefficient based on the index period can be applied to the time series to simulate the increases or decreases in M\&I demand resulting from population growth or decline. Thus, this time series can be considered an index time series that can be adjusted by the model user. This time series is used to simulate M\&I demand for water from channel reaches of the Truckee River between the Farad and Vista gaging stations in the operations model.

\section{Lake Level and Streamflow Forecasts}

Lake level and streamflow forecasts are often used to guide decisions in the model for reservoir and river operations. Forecasts of lake levels at Lake Tahoe and flows at the gaging station Little Truckee River above Boca Reservoir, near Truckee, Calif., the Farad gaging station, and the gaging station Carson River near Fort Churchill, Nev., were provided by the Natural Resources Conservation Service (NRCS) (Rebecca Wray, Natural Resources Conservation Service, written commun., 1995). Forecasts at these locations were computed using the Extended Streamflow Prediction package (ESP) (Day, 1985) and the PRMS system (Leavesley and others, 1983) for those parts of the simulation period prior to the availability of NRCS forecasts. Other forecasts at locations and for periods not afforded by the NRCS also were computed using ESP/PRMS. All forecasts are for flows that would occur without regulation from upstream reservoirs.

\section{DESCRIPTION AND SIMULATION OF TRUCKEE RIVER BASIN OPERATIONS}

The constructed model simulates three major options regarding Truckee River Basin operational practices. The first option characterizes current (1998) operational practices and incorporates them into the model code of the SPCL block. The second option combines existing and proposed (draft TROA, WQSA) operations. The second option contains all of the constraints from the first option, but simulates additional proposed operations. The third option simulates WQSA without draft TROA and is not described separately in this report.

The logic in the daily operations model represents the Truckee River operational practices that are governed by the water rights, court decrees, agreements, regulations, and informal conventions. Policies and rules within these legal documents can, therefore, be considered as quantitative and qualitative data that guided the development of the model code. Successful simulation of Truckee River Basin operations was achieved by representing these policies and rules in the code so that simulated flows and volumes conform to those legal constraints.

The model simulates reservoir and river operations as governed by both physical processes and legal constraints. Initial volume and flow conditions are derived from user-specified initial conditions. The general logic in the operations model used to characterize current and proposed rules and policies governing Truckee River operations is shown as a flowchart on figure 4 . Boxes on figure 4 represent one or more operational subblocks in the SPECL block of the model. The following discussion provides a generalized overview of the model subblocks and terms as shown in the flowchart. The subblocks are grouped in general classifications, and each classification is defined and discussed. To simplify this overview, the model subblocks are only generally referenced, and therefore the discussion of the general classifications in this section does 
not follow the same order as the boxes in the flowchart (fig. 4). The subblocks, shown in bold italics, are discussed in more detail in subsequent sections, as will undefined terms introduced in the following overview.

For each time interval, miscellaneous constants and flags are assigned in the SPECL subblock called initial assignments and computations. Initial assignments and computations are made prior to simulations of releases, diversions, and exchanges. They include miscellaneous constants such as reservoir outlet capacities based on current reservoir stage; irrigation demands transferred to other uses, such as M\&I demand or water-quality demand; minimum, enhanced, and preferred flow targets; recreation pool levels; Floriston rates targets; and M\&I credit water base amounts.

Many of these assignments are provided as default values, but because they may be revised by the modeler, they are called user options. Flags are integer values that direct a model run to simulate designated parts of model code. Flags may be user-option flags or computed flags. User-option flags may be revised by the modeler. Computed flags are assigned by the model code during a simulation.

Flood-control criteria, simulated in the subblock flood-control criteria, determine when and how much water must be released from reservoirs to maintain reservoir flood-control space and thus minimize potential downstream flood damages. Flood-control criteria govern operations for all major reservoirs in the study area except for Lake Tahoe, where flood-control operations have not been formalized. Flood-control operations are different for each reservoir, and may include storage of water to avoid downstream flooding; precautionary drawdowns to avoid spills by decreasing reservoir storage to a lower threshold for the winter, called the wintertime cap; maintenance of the wintertime cap; spring filling rules; and maintenance of maximum reservoir volume during the summer. Floodcontrol operations are simulated by adjustment of reservoir releases. Uncontrolled spills, as the name suggests, cannot be managed but are computed within this subblock because they are closely related to floodcontrol criteria. Uncontrolled spills and flood-control operations have priority over other operations and are, therefore, simulated before other operations. Although operations based on flood-control criteria are not tied to specific water categories, water categories are assigned to releases determined for flood-control operations during simulations.
Storage priorities of reservoirs under current operations, simulated in the subblock reservoir storage priorities and pass-through requirements, dictate when and how much water of a specific water category can be stored in reservoirs. The principal water category that a reservoir was built or authorized to provide storage for is often called project water. Depending on reservoir priorities, current reservoir storage, and legal constraints, a reservoir may store project water by retaining all or part of reservoir inflow. If a reservoir does not currently have priority to store any project water, then that reservoir must "pass through" all inflows to a downstream reach for a higher-priority use, such as maintenance of Floriston rates or diversion to the Truckee Canal. Thus, by adjustment of reservoir releases in model simulations, a reservoir may store inflows or release stored water. Pass-through water retains the same category, but water may be stored under different categories depending on current reservoir storage and legal constraints. Some storage operations are allowed that facilitate coordination of reservoir releases to increase operational efficiency or are made by contractual agreement. These storage operations include contract storage in Stampede and Boca Reservoirs and storage of PCPOSW (Power Company privately owned stores water) in Boca Reservoir.

Just as simulated flood-control criteria determine when and how much water must be released from reservoirs, numerous simulated demands for water also dictate releases from reservoir storage. These demands are satisfied by adjustment of simulated reservoir releases and are typically prioritized on the basis of various rules, policies, and conventions. Computations that specify these release adjustments are made within several subblocks that simulate maintenance of Floriston rates and instream flows, and satisfaction of a number of demands including Power Company M\&I, Newlands Project irrigation and wetlands supply, Pyramid Lake fishes, California M\&I, and waterquality demands. Releases may consist of either "tagged" or "untagged" waters. Tagged releases must consist of specific water categories whereas untagged releases may consist of any category in the reservoir. The assignment of various categories to untagged releases is discussed in a subsequent section, "Merge Reservoir Releases for Multiple Objectives." When categories are assigned to the untagged water for a given time interval, they become tagged releases for 


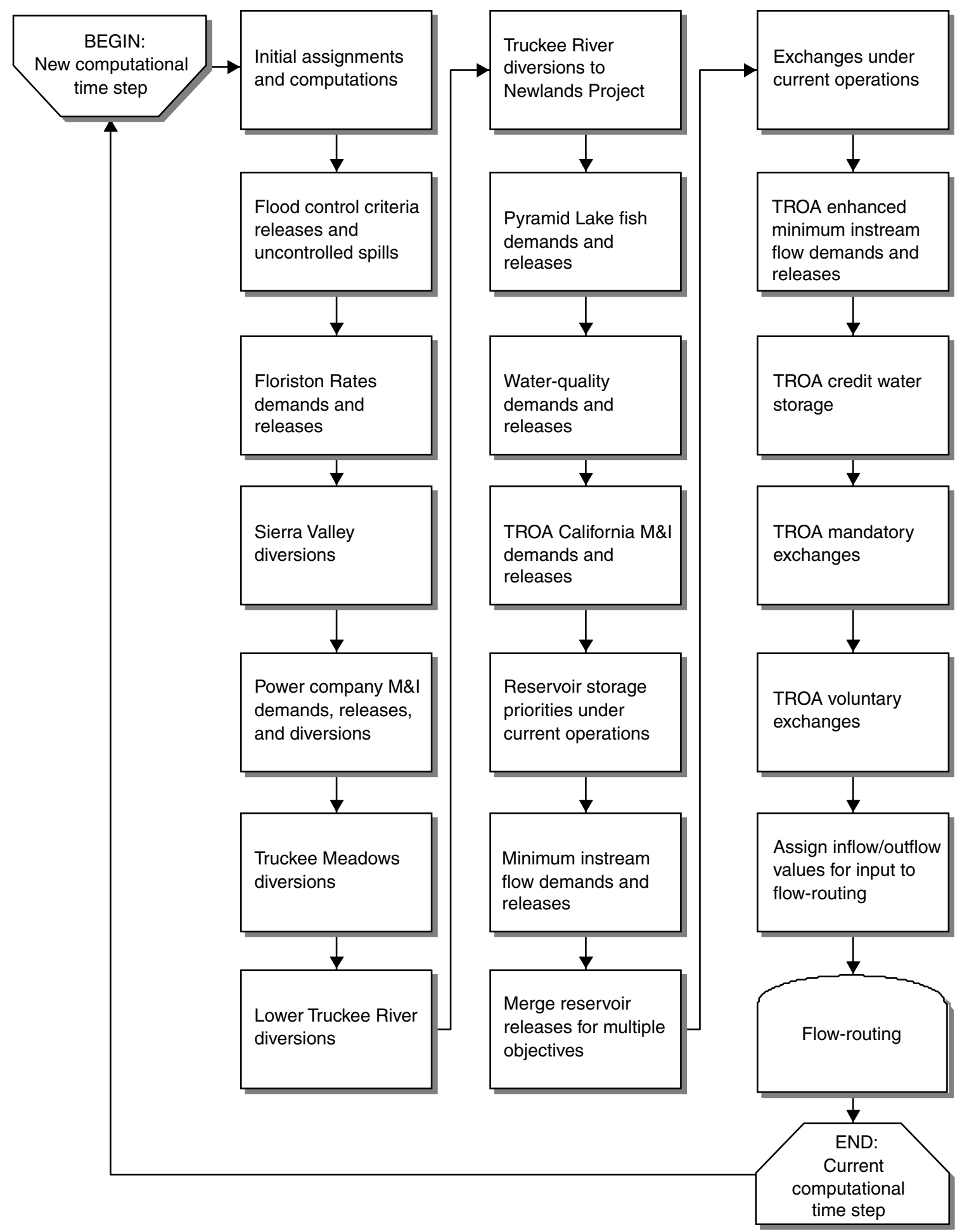

Figure 4. Generalized flowchart of U.S. Geological Survey Truckee River Basin operations model 
just that time interval. Releases specified in this overview are tagged releases except for those necessary to maintain current minimum flows and those based on flood-control criteria. Although maintenance of current minimum flows may require reservoir releases, usually no specific water categories are dedicated for their maintenance. As with any release, releases to meet demands are constrained by the capacity or hydraulic rating of the outlet works of each dam for a given storage level. It is assumed that all outlet gates in the penstock and spillway are open when determining the maximum release from each reservoir.

The term "river diversions" is used to reference simulated river operations that divert water from a channel reach to a specific off-river point of use. These diversions are usually outflow boundaries, and, except for return flows, water diverted from a channel reach is assumed to be consumptively used and is lost from the simulation. However, water diverted to the Truckee Canal is routed to Lahontan Reservoir along designated reaches. M\&I and agricultural demands govern the volume of water diverted from each of the channel reaches. For the three simulation options described previously, diversions of specific water categories are determined by subblocks governing diversions in four segments of the flow-routing model: (1) diversions from the Little Truckee River to Little Truckee Ditch for agricultural demands in California outside of the Truckee River Basin, determined in the subblock Sierra Valley diversions; (2) diversions from the Truckee River between the Farad and Vista gaging stations to various ditches and intakes for M\&I and agricultural demands in the Truckee Meadows, determined in the subblock Truckee Meadows diversions; (3) diversions from the Truckee River downstream from the Vista gaging station, except for the Truckee Canal, to various ditches for agricultural demands, determined in the subblock lower Truckee River diversions; and (4) diversion from the Truckee River to the Truckee Canal for project demands (agricultural and wetlands) of both the Truckee and Carson Divisions of the Newlands Project, determined in the subblock $\boldsymbol{O C A P}$. Additionally, under the draft TROA simulation option, diversions from the Truckee River near the town of Truckee, Calif., are simulated for California M\&I uses in the subblock California M\&I demands. Diversions are influenced by various parameter assignments in the initial assignments and computations subblock. For example, the diversion from the Little Truckee River to the Little Truckee Ditch is influenced by natural flow at the Farad gaging station, calculated as outlined by the Sierra Valley Decree in the initial assignments and computations subblock. Diversions also exert influence on other simulated operations. For example, the forecasted diversion of water from the Truckee River to the Truckee Canal in the $\boldsymbol{O C A P}$ subblock influences reservoir releases for Pyramid Lake fish determined in the subblock that satisfies cui-ui spawning demands. Water may also be diverted directly from Lake Tahoe and Donner Lake for local M\&I use.

Proposed reservoir releases that satisfy water right demands and other operational requirements are compared and evaluated to determine a merged release value for each reservoir in the subblock merge. The merge subblock assigns water categories for those proposed releases that do not require a specific category because, for accounting, all releases must be assigned to water categories. These untagged releases come from the subblocks that compute releases necessary to meet flood-control criteria and releases to make minimum flows. If both untagged and tagged waters must be released, then the untagged waters will be satisfied by the volume of tagged water released, and will assume the categories of the tagged-water demands up to a maximum of the proposed tagged releases. If untagged releases are greater than the demand for tagged releases, then categories are assigned, by a priority scheme, to that part of the untagged release that is greater than the proposed tagged releases. For example, suppose flood-control operations require an untagged release of $100 \mathrm{ft}^{3} / \mathrm{s}$ from a reservoir. Water categories must be assigned to the entire untagged release. The untagged release may assume up to $100 \mathrm{ft}^{3} / \mathrm{s}$ of various water categories from tagged releases from that reservoir. Thus, if tagged releases of $100 \mathrm{ft}^{3} / \mathrm{s}$ are proposed, then the entire untagged release will be satisfied by the $100 \mathrm{ft}^{3} / \mathrm{s}$ tagged releases and the untagged release may assume the categories of the tagged releases. However, if the tagged releases are only $60 \mathrm{ft}^{3} / \mathrm{s}$, then only $60 \mathrm{ft}^{3} / \mathrm{s}$ of the $100 \mathrm{ft}^{3} / \mathrm{s}$ untagged release will assume those water categories from the tagged releases, and then categories, if present in reservoir storage, must be assigned to the remaining untagged release of $40 \mathrm{ft}^{3} / \mathrm{s}$.

A commonly used water-management transaction known as water exchange allows reservoir operators to meet multiple-use goals by moving stored water from one reservoir to another. Exchanges always involve specific quantities of specific water categories. There 
are three types of exchanges: (1) nonphysical exchange of a volume of water in one or more reservoirs for water in one or more other reservoirs, which, for this report, will be referred to as a paper exchange; (2) release of water from one reservoir for storage in a downstream reservoir, often called re-storage; and (3) release of one or more categories of water from one or more reservoirs in lieu of a release of water of yet another category from one or more other reservoirs, often called an in-lieu-of exchange. Exchanges always occur after all demands and constraints are considered to arrive at a proposed release. Exchanges are commonly meant to modify proposed releases of individual reservoirs, but not the total release from all reservoirs.

Related to an exchange, the term transfer is used in this report to describe another mechanism to establish or accumulate proposed water categories.

Although exchanges also may be used to establish or accumulate proposed water categories, transfers involve only one reservoir and the gain of a water category volume results from the conversion, or loss, of another category volume. Unlike exchanges, with transfers, the total releases from reservoirs may be modified. For example, a proposed reservoir operation called credit storage involves the transfer of the water category pooled water to a new credit water category. The volume of pooled water is transferred to a new credit water category retained in storage as a result of the reduction of the pooled water release.

Simulation of current operations and, to a greater extent, proposed operations use exchanges and transfers of water categories between or within reservoirs as a method to attain multi-purpose storage and release objectives. Exchanges that are currently practiced are limited, but include a Tahoe-Prosser Exchange and a Donner-Boca Exchange. Both exchanges are simulated in the subblock current exchanges. Listed below are exchanges and transfers that are a part of proposed operations and the operations model subblocks in which they are simulated.

- Exchanges to meet draft TROA enhanced and preferred instream flows-simulated in the subblocks enhanced minimum instream flows and preferred instream flows, respectively.

- Transfers to establish and store proposed water categories-simulated in the subblocks California $M \& I$ creation and credit storage.
- Several miscellaneous exchanges and transfers that involve storage rules of proposed water category volumes in specific reservoirs-simulated in the subblock TROA mandatory exchanges.

- Voluntary exchanges that involve specific objectives, such as exchanges of water categories for more efficient use of reservoir spills and drawdowns, maintenance of recreational pools, and optimal locations (in terms of security and access) for storage - simulated in the subblocks enhanced storage security, efficient use of releases, and maintenance of recreational pools.

Simulated transfers are specified by criteria in draft TROA, but exchanges may be mandatory or voluntary. Mandatory exchanges are specified for certain water categories and purposes in draft TROA. Voluntary exchanges would be requested by interested parties. The types of water exchanges and water categories involved with voluntary exchanges are discussed in more detail later in the text.

For simulation of proposed operations, exchanges and transfers are important methods to modify simulated reservoir releases. To simulate proposed minimum and preferred instream flows downstream from a reservoir, for example, proposed water categories might be exchanged between two reservoirs, resulting in reduced releases from one reservoir and increased releases from the reservoir upstream from the instream flow requirement. Another example involves simulated storage of proposed water categories by a transfer. Establishment of Power Company M\&I credit water, for example, involves storage of the consumptive use portion of former agricultural water rights adjudicated by the Orr Ditch Decree (United States of America $v$. Orr Ditch Water Company, Equity No. A-3 (D. Nev. 1944)) and acquired by Power Company for M\&I use. Storage of Power Company M\&I credit water may only be implemented to the extent that a reservoir would be releasing or passing through water to satisfy Orr Ditch Decree rights and, thus, Floriston rates. Therefore, water that would be released to maintain Floriston rates would be held in reservoir storage and assigned (transferred to) the category of Power Company M\&I credit water.

The preceding discussion provided a general overview of the simulation of many current and proposed types of operations that move volumes of water from one reach to another, from one water category to 
another, or out of a reach during a time interval. The result of these operations is water volumes diverted, exchanged, or released from channels and reservoirs. These volume and flow quantities are used by the RCHRES block of HSPF to route flows, move water from reaches through various outlets, and exchange water categories from one reservoir to another.

\section{Description and Simulation of Current Operations}

Current reservoir and river operations are implemented primarily by adjusting reservoir releases, exchanging water categories between reservoirs, and diverting specific water categories from a channel. Adjustment of reservoir releases allows the reservoir operator to pass through inflows to downstream reaches, store inflows, and release water from reservoir storage for a variety of objectives. Exchanging water categories between reservoirs enables water managers to meet multiple-use goals. Finally, river diversions to meet irrigation and M\&I demands are based on water rights. The following sections describe currently designated water categories, currently practiced river and reservoir operations, and losses and gains to reaches.

\section{Current Water Categories}

The following water categories and their definitions are used in the USGS Truckee River Basin operations model to simulate current reservoir and river operations.

- fish water-Waters stored in or released from Stampede Reservoir, uncommitted water released from Prosser Creek Reservoir, or other waters released to the Truckee River for the benefit of threatened or endangered fishes of Pyramid Lake.

- natural water-Water that originates from flow in Truckee River tributary subbasins not regulated by a reservoir or from flow that is passed through a reservoir without detention, except Lake Tahoe.

- pooled water-Water stored in Lake Tahoe and Boca Reservoir pursuant to the Orr Ditch Decree and the Truckee River Agreement that is dedicated to supporting Floriston rates. Also included in this designation are adverse- and non-adverseto-canal waters stored in the reservoir. Adverseto-canal water, historically referred to as supple- mental storage water, refers to the first 25,000 acre-ft of pooled water stored (or, if a lesser quantity is stored, then such lesser quantity) in Boca Reservoir in a given water year. Nonadverse-to-canal water, historically referred to as additional supplemental storage water, refers to pooled water stored in addition to adverse-to-canal water up to the capacity of Boca Reservoir. Non-adverse-to-canal water cannot be stored adverse to Truckee Canal diversions.

- privately owned stored water (POSW) - Water stored under the water rights of Power Company in Independence Lake and the water rights of Power Company and TCID in Donner Lake.

- Tahoe-Prosser Exchange water (TPEW) Water stored in Prosser Creek Reservoir that is established in accordance with the Tahoe-Prosser Exchange Agreement and intended to be released for the purpose of maintaining Floriston rates.

- uncommitted water-Water stored in Prosser Creek Reservoir that is dedicated to the purposes of the Tahoe-Prosser Exchange Agreement for the establishment of Tahoe-Prosser Exchange water. Uncommitted water can be used for the benefit of threatened and endangered fishes of Pyramid Lake.

\section{Current Reservoir Operations}

Current reservoir operations are governed by rules in legal decrees and agreements. These reservoir operations primarily involve the adjustment of reservoir releases, but also include exchanges of water between reservoirs in the Truckee River Basin. This section describes currently-practiced reservoir operations and discusses how each operation is implemented in the model.

\section{Flood-Control Criteria}

Flood-control criteria are rules that specify (1) mandatory reservation of flood-control space in reservoirs and (2) maximum downstream river flows. Two types of spills are closely related to operations for flood-control criteria. First, an uncontrolled spill can occur when reservoir levels rise and outflows cannot be regulated by reservoir outlet structures. During uncontrolled spills, additional reservoir storage (termed surcharge) may actually exceed design storage values when inflows exceed the hydraulic capacity of 
the dam spillway. The second type, precautionary drawdown releases or controlled (planned) spills, occur when water is released through reservoir outlet structures only to lower the reservoir level and maintain flood-control space in the reservoir.

Truckee River Basin reservoirs are operated for flood-control criteria based on various regulations and procedures specified in several documents from different agencies. Martis Creek Lake and Prosser, Stampede, and Boca Reservoirs are operated in accordance with USCOE flood-control criteria (U.S. Army Corps of Engineers, 1985). Lake Tahoe has no USCOE flood-control criteria, but is managed according to the Truckee River Agreement. Donner and Independence Lakes are operated to comply with California licensing requirements and dam safety criteria. Flood-control criteria for Lahontan Reservoir is specified for emergency and general release procedures (Dave Overvold, Bureau of Reclamation, written commun., 1996, 1997).

Flood-control criteria operate seasonally: fall, winter, spring, and summer. The fall precautionary drawdown period requires that reservoir levels be lowered to ensure sufficient flood-control space during the winter and spring. The drawdown period typically begins in late summer and ends by about November 1 . During the winter, the reservoirs maintain flood-storage space at a constant reservoir elevation of wintertime cap. This period is typically November to late March. The spring filling season, from about April to June, is the period when the reservoirs are filled to maximum storage capacity with snowmelt runoff. During the summer months, from June to August, reservoirs are managed to meet downstream demands.

The following sections describe the flood-control criteria for each reservoir under current operations and as simulated in the operations model in the subblock

flood-control criteria. General assumptions for floodcontrol criteria for all reservoirs in the model are as follows: the maximum release is based on the outlet capacity for each reservoir with all outlet gates open except for Lake Tahoe; when the reservoir elevation is less than the spillway crest, the outlet capacity is the outlet discharge rating curve; when the reservoir elevation is greater than the spillway crest, the outlet capacity is both the outlet and the spillway rating curves; and when the simulated flow is larger than $6,000 \mathrm{ft}^{3} / \mathrm{s}$ at Truckee River at Reno (reach 350), Prosser, Stampede, and Boca Reservoirs are simulated according to flood- control criteria to minimize releases and, therefore, to maximize storage below their respective reservoir spillway elevations.

\section{Lake Tahoe}

The portion of Lake Tahoe controlled by Tahoe Dam provides 744,600 acre-ft of storage between the natural rim elevation of 6,223.0 ft and the maximum storage elevation of 6,229.1 ft (U.S. Geological Survey, 1996, p. 336). The goal of Lake Tahoe flood operations is to not allow the lake elevation to exceed 6,229.1, as specified in the Truckee River Agreement of 1935. Estimates of the forecasted rise of the lake are made on March 1 and April 1 of each year. When the current lake elevation is less than $6,228.0 \mathrm{ft}$, but the estimated rise is expected to exceed 6,230.0, the outflow is set to the maximum rate possible to remove that amount of water forecasted to be in excess of $6,230.0 \mathrm{ft}$. When the current lake elevation exceeds $6,228.0$, the outflow is set to the maximum rate possible to remove that amount of water forecasted to be in excess of 6,229.1 ft (the maximum storage elevation). At low lake levels, maximum outflow rates are hydraulically controlled by the natural rim of the lake. At high lake levels, the dam is the dominant control for outflows. The FWM attempts to keep Lake Tahoe releases to the Truckee River to less than $2,600 \mathrm{ft}^{3} / \mathrm{s}$ to avoid potential damage to a downstream sewage pipeline and other property damage. There is no emergency spillway, nor are there fall precautionary drawdowns or spring filling seasons defined for the lake.

The USGS Truckee River Basin operations model simulates operations resulting from high lake levels for Lake Tahoe as follows. In the subblock

flood-control criteria, if the simulated Lake Tahoe elevation is less than $6,227.8 \mathrm{ft}$, there is no flood control release. When the simulated lake elevation is greater than $6,227.8 \mathrm{ft}$, the model forecasts probable maximum elevation of the lake for the year. If the forecasted elevation is less than $6,228.5 \mathrm{ft}$, then flood control release is set to zero. If the forecasted elevation is greater than $6,228.5 \mathrm{ft}$, then flood control releases are determined for two cases: If Truckee River flow at Reno (reach 350 ) is greater than $6,000 \mathrm{ft}^{3} / \mathrm{s}$, the lake release is set to the inflow up to a maximum of $2,600 \mathrm{ft}^{3} / \mathrm{s}$; otherwise, the forecasted volume in excess of $6,228.5 \mathrm{ft}$ is then released uniformly as a precautionary drawdown over the next 30 days to achieve an elevation of $6,228.5 \mathrm{ft}$ at the end of the 30-day period. When the lake elevation 
is higher than $6,229.1 \mathrm{ft}$, releases are considered, in the operations model, to be uncontrolled spills from the lake and outflows are compared to the maximum of $2,600 \mathrm{ft}^{3} / \mathrm{s}$.

\section{Donner Lake}

Donner Lake, operated by the Power Company, can provide a maximum effective flood control space of about 6,000 acre-ft (Richard D. Moser, Sierra Pacific Power Company, oral commun., 1999) due to outlet channel constraints just upstream from Donner Lake Dam. Releases to avoid potential problems caused by high water levels are established by California Division of Safety of Dams regulations (Richard D. Moser, Sierra Pacific Power Company, oral commun., 1995). Within these regulations, the lake is operated using hydrologic judgement, information about current lake elevation, forecasted runoff conditions, and historical lake inflow patterns (Richard D. Moser, Sierra Pacific Power Company, oral commun., 1995). Hydrologic judgement is defined as using available or forecasted hydrological and meteorological data to make an operational decision. Uncontrolled spills above a lake elevation of $5,935.8 \mathrm{ft}$ will equal the lake inflows. The fall precautionary drawdown season is typically defined as September 1 to November 15. During this period, the lake elevation is reduced to $5,926.9 \mathrm{ft}$ to provide flood-control space. At that elevation, the upper two gates in the dam are held in the open position from November 16 to about April 15. However, partial filling of the lake may be allowed earlier if forecasts indicate below-average runoff conditions.

The Donner Lake springtime filling season occurs from about April 16 to June 15 when the lake can be filled to a maximum allowable elevation of $5,935.8 \mathrm{ft}$, using a flexible schedule based on runoff projections. When the lake elevation is less than the spillway crest, the outlet capacity is the outlet discharge rating curve (Richard D. Moser, Sierra Pacific Power Company, written commun., 1995). When the lake elevation is greater than the spillway crest, the outlet capacity is the spillway rating curve (Richard D. Moser, Sierra Pacific Power Company, written commun., 1995). The emergency spillway becomes effective at an elevation of $5,936.8 \mathrm{ft}$.

The preceding Donner Lake flood-control criteria were implemented in the code as follows. Lake releases are simulated on the basis of the flood-control criteria from uncontrolled spills and precautionary drawdowns.
The flood-control criteria can be separated into five conditions or periods: uncontrolled spills, fall, winter, spring, and summer. To simulate uncontrolled spills when the lake elevation is greater than $5,935.8 \mathrm{ft}$, the releases are set equal to the inflow times 1.5., a factor that approximates the hydrologic judgement typically used for uncontrolled spill operations. During the fall precautionary drawdown season, September 15 to November 15, lake elevation is lowered to and maintained at 5,926.9 ft. During this period, any water above this elevation is calculated daily and parcelled into daily volumes for prorated release from the current date until November 15 . Wintertime reservoir capacity is specified in the code from November 16 to May 1 on the basis of a qualitative "runoff index," which designates an upcoming runoff season as wet, average, or dry according to forecasts (see the section "Runoff Index," under the section "Forecasts Affecting Operational Decisions"). For example, under conditions forecast as dry, as determined by the runoff index, the wintertime reservoir capacity is increased beginning February 15, earlier than under normal or wet forecast conditions. When reservoir storage exceeds the wintertime cap, the amount exceeding the wintertime cap is released. Springtime reservoir capacity is specified in the code from May 2 to June 15 based on the runoff index and storage curves provided by Richard D. Moser (Sierra Pacific Power Company, written commun., 1995). The allowable reservoir storage is calculated every 15 days and releases are simulated on the basis of the amount of storage above the calculated springtime reservoir storage. In the summer, from June 16 to September 14 , storage above $5,935.8 \mathrm{ft}$ is released.

\section{Martis Creek Lake}

Martis Creek Lake, operated by the USCOE, can provide 20,000 acre-ft of flood-control space. However, the full capacity of Martis Creek Lake is rarely used and never for extended storage. USCOE regulations state that outlet releases are limited to 100 $\mathrm{ft}^{3} / \mathrm{s}$ during periods of normal inflows (U.S. Army Corps of Engineers, 1985, p. VII-3). When forecasts indicate the flow at Truckee River at Reno will exceed $14,000 \mathrm{ft}^{3} / \mathrm{s}$, Martis Creek Lake outflow gates are closed. When Truckee River at Reno flow is between $6,000 \mathrm{ft}^{3} / \mathrm{s}$ and $14,000 \mathrm{ft}^{3} / \mathrm{s}$, Martis Creek Lake outflow 
is limited to the inflow. There is no specified fall precautionary drawdown season or spring filling season defined for Martis Creek Lake.

The Martis Creek Lake flood-control criteria were implemented in the code as follows. In the subblock flood-control criteria, when the simulated Martis Creek Lake elevation is greater than $5,838.0 \mathrm{ft}$ and the Truckee River flow at Reno (reach 350) is greater than $6,000 \mathrm{ft}^{3} / \mathrm{s}$, the uncontrolled spill is set equal to the inflow. Flood control releases for Martis Creek Lake are simulated depending on Truckee River at Reno flow and reservoir levels under the following conditions. When flow at Truckee River at Reno exceeds $14,000 \mathrm{ft}^{3} / \mathrm{s}$, Martis Creek Lake outflow is set to zero. When Truckee River at Reno flow is between 6,000 $\mathrm{ft}^{3} / \mathrm{s}$ and $14,000 \mathrm{ft}^{3} / \mathrm{s}$, Martis Creek Lake precautionary drawdown releases are limited to reservoir inflow. When Martis Creek Lake level is less than 5,782 ft, precautionary drawdowns are set equal to inflows. Outlet releases are limited to a maximum of $100 \mathrm{ft}^{3} / \mathrm{s}$ during non-flood periods.

\section{Prosser Creek Reservoir}

Prosser Creek Reservoir is operated by BOR and can provide 20,000 acre-ft of flood-control space when the wintertime cap is in place. When the reservoir level exceeds 5,741.2 ft, the discharge rating curve (U.S. Army Corps of Engineers, 1985, Chart A-4-2) dictates releases for the reservoir spillway. The fall precautionary drawdown season is defined as October 1 to October 31 (U.S. Army Corps of Engineers, 1985). However in practice, reservoir precautionary drawdowns can begin as early as September 1 . This early drawdown date allows basin managers more flexibility in attaining multiple uses with reservoir releases to create flood-control space. During this period, the reservoir's elevation is reduced to $5,703.7 \mathrm{ft}$ and held at or below this level from November 1 to April 9. The spring filling season lasts from April 10 to May 20, based on runoff conditions, but filling can be delayed to as late as July 4 in wet years. If forecasted runoff is higher than certain volumes specified by the USCOE Flood-Control Diagram (U.S. Army Corps of Engineers, 1985, Chart A-8-1), then additional reservoir flood space must be maintained to accommodate the increased flood threat.

The guidelines and rules for Prosser Creek Reservoir flood-control criteria were implemented in the code as follows. In the subblock flood-control criteria, uncontrolled spills and precautionary drawdowns are simulated. When the simulated reservoir elevation is greater than 5,741.2 ft, uncontrolled spills are set equal to the hydraulic rating of the river outlet structure and spillway combined. During the fall precautionary drawdown season, the storage volume simulated above reservoir elevation of $5,703.7 \mathrm{ft}$ is calculated daily beginning September 3 and precautionary drawdowns releases are parcelled into equal daily volumes for prorated release from the current date to October 31. When reservoir storage exceeds the $5,703.7 \mathrm{ft}$ wintertime cap, that excess water is released as precautionary drawdowns. Allowable storage during the springtime filling season from April 10 to July 4 is based on the USCOE Flood-Control Diagram (U.S. Army Corps of Engineers, 1985, Chart A-8-1). Simulations of daily releases of precautionary drawdowns are based on the amount of allowable reservoir storage shown by this diagram.

\section{Independence Lake}

Independence Lake, operated by the Power Company, can provide a maximum effective flood control space of 3,000 acre-ft during periods when the wintertime cap is in place. Releases to avoid potential problems caused by high water levels are established by California Division of Safety of Dams regulations. Within these flood-control criteria, the lake is operated using hydrologic judgement and information about current lake elevation, forecasted runoff, and historical lake inflow patterns (Richard D. Moser, Sierra Pacific Power Company, oral commun., 1995). When the lake levels exceed 6,949.3 ft (17,500 acre-ft), uncontrolled spills begin, which are governed by the spillway rating (Richard D. Moser, Sierra Pacific Power Company, written commun, 1995) to avoid endangering the dam structure. The fall precautionary drawdown season is defined as August 15 to November 1. During this period, the lake elevation is reduced to the elevation of the flashboards in the two bays of the emergency spillway $(6,944.7 \mathrm{ft})$ (Richard D. Moser, Sierra Pacific Power Company, oral commun., 1999). This flood space allows for additional storage during high runoff periods in the winter. Independence Lake is typically held below 6,946.3 ft from November 2 to May 15. The springtime filling season begins May 15 and continues until about July 15 when the lake is filled to a maximum stage of $6,949.3 \mathrm{ft}$ or storage of 17,500 acre-ft. The Power Company uses flexible schedules to fill the 
lake, based on runoff projections and consideration of temperature and remaining snowpack with reservoir filling at the end of the runoff period.

The guidelines and rules for Independence Lake flood-control criteria were implemented in the code as follows. In the subblock flood-control criteria, uncontrolled spills and precautionary drawdowns are simulated. When the simulated lake elevation is greater than $6,949.3 \mathrm{ft}$, the uncontrolled spills are set equal to the inflow times 1.5 , a factor used as an approximation of the hydrologic judgement typically used for uncontrolled spill operations. During the fall precautionary drawdown season, the simulated volume above lake elevation of 6,944.7 ft is calculated on August 15 and October 17 and precautionary drawdowns are parceled into equal daily volumes for prorated releases from the current date to November 1. Wintertime (November 2 to June 1) storage limit is based on the runoff index. For example, if the index forecasts below-average runoff conditions, the wintertime cap limit capacity is increased beginning February 1. When reservoir storage exceeds the current wintertime cap, the excess is released. The lake storage limit during filling season (June 2 to July 15) is based on the runoff index and storage curves provided by R. Moser (Sierra Pacific Power Company, written commun., 1995). The allowable reservoir storage is calculated every 7 days and precautionary drawdowns are based on the amount of storage in excess of the allowable reservoir storage limit. From July 16 to August 14, when reservoir levels exceed $6,948.5 \mathrm{ft}$, the excess greater than that amount above $6,948.5 \mathrm{ft}$ is released.

\section{Stampede and Boca Reservoirs}

Stampede and Boca Reservoirs, operated by the BOR and WCWCD, respectively, provide a combined total of 30,000 acre-ft of flood-control space. These two reservoirs are operated in tandem for flood control. The fall precautionary drawdown season is defined as October 1 to October 31. During this period, the Stampede and Boca Reservoir elevations are reduced to the wintertime storage limits of elevation of 5,942.1 $\mathrm{ft}$ and 5,596.4 ft, respectively. These elevations are held through the winter from November 1 to April 9. Springtime filling season for the reservoirs is from April 10 to July 4. Springtime filling criteria are constrained by the USCOE Flood-Control Diagram (U.S. Army Corps of Engineers, 1985, Chart A-8-2). Also, when Boca Reservoir levels exceed 5,605.0 ft, uncon- trolled spills are governed by the Emergency Spillway Release Diagram (U.S. Army Corps of Engineers, 1985, Chart A-9).

The guidelines and rules for Stampede Reservoir flood-control criteria were implemented in the code as follows. When the simulated reservoir elevation is greater than 5,948.7 ft, uncontrolled spills are simulated as the maximum capacity of the river outlet structure and spillway. During fall precautionary drawdown season, the storage volume simulated above the reservoir elevation of 5,942.1 ft is calculated daily and releases are parcelled into equal daily amounts from October 1 until October 31. A wintertime cap of 5,942.1 $\mathrm{ft}$ is specified from November 1 to April 9. When reservoir storage exceeds the wintertime cap, the excess water is released as precautionary drawdowns. Releases due to precautionary drawdowns during the springtime filling season are made in accordance with the USCOE Flood-Control Diagram (U.S. Army Corps of Engineers, 1985, Chart A-8-2).

The guidelines and rules for Boca Reservoir flood-control criteria were implemented in the code as follows. In the subblock flood-control criteria, when the reservoir elevation is greater than $5,600.0 \mathrm{ft}$, the uncontrolled spills are simulated as the volume of water above $5,600.0 \mathrm{ft}$ and are constrained by the hydraulics of the outlet works and spillway. During the fall precautionary drawdown season, any storage greater than the reservoir elevation of $5,596.4 \mathrm{ft}$ is calculated daily and released as precautionary drawdowns in equal daily amounts from October 1 until October 31. A wintertime cap of $5,596.4 \mathrm{ft}$ is maintained from November 1 to April 9. When reservoir storage exceeds the wintertime cap, the excess water is released. Releases for precautionary drawdowns during the springtime filling season are made in accordance with the USCOE Flood-Control Diagram (U.S. Army Corps of Engineers, 1985, Chart A-8-2).

\section{Lahontan Reservoir}

Lahontan Reservoir, operated by TCID, provides 317,700 acre- $\mathrm{ft}$ of storage between $4,060.0 \mathrm{ft}$ and $4,163.67 \mathrm{ft}$, the maximum reservoir elevation with flashboards on the spillway crest (U.S. Geological Survey, 1996, p. 184). The current average height of the flashboards is 18 inches, which creates a reservoir storage volume of 316,900 acre-ft. Operating criteria do not allow the reservoir water surface to rise on the flashboards until the peak spring runoff has passed 
(Alan Olson, Bureau of Reclamation, written commun., 1999). Lahontan Reservoir flood operations are designed to prevent the reservoir elevation from exceeding a monthly maximum as specified in BOR regulations "General Filling Schedule and Release Procedures" for the reservoir (Alan Olson, Bureau of Reclamation, written commun., 1996). Estimates of the rise of the reservoir are forecasted on April 1 of each year. When the forecasted rise exceeds the maximum allowable storage limits, water is released to satisfy precautionary drawdown criteria. Outflow rates are confined by the maximum capacity of the reservoir power plant and river outlet works to about $2,500 \mathrm{ft}^{3} / \mathrm{s}$. Any large releases or uncontrolled spills over the spillway greater than $2,000 \mathrm{ft}^{3} / \mathrm{s}$ can create localized flooding downstream from the reservoir. This condition is avoided whenever possible. Spring filling elevations defined for the reservoir are based on the optimal storage targets set forth for each month in OCAP.

The criteria upon which flood-control releases due to pre-cautionary drawdowns are simulated within the USGS Truckee River Basin operations model in the subblock flood-control criteria as follows. Precautionary drawdown releases for Lahontan Reservoir are defined as those releases over and above the normal releases to meet project demand. If the daily stage of Lahontan Reservoir is less than 4,156.0 ft, then the flood-control release is set equal to 0 . If the daily stage of Lahontan Reservoir is greater than $4,156.0 \mathrm{ft}$ but less than $4,163.0 \mathrm{ft}$, a forecasted reservoir volume is computed, based either on NRCS forecasts of April-July runoff volume for the Carson River near Fort Churchill (used in code computations for the period JanuaryMay) or daily inflow times 21 days (used in code computations for the period June-December). The forecasted volume provides an estimate of inflow in the next three weeks to approximate the judgement used for reservoir operations. Projected releases to meet project demand and projected reservoir losses are not considered in this calculation. If the daily stage of Lahontan Reservoir is between 4,163.0 ft and 4,164.0 $\mathrm{ft}$, then the precautionary drawdown release is set to $3,000 \mathrm{ft}^{3} / \mathrm{s}$. If the daily stage of Lahontan Reservoir is greater than $4,164.0 \mathrm{ft}$, then the precautionary drawdown release is set to $4,000 \mathrm{ft}^{3} / \mathrm{s}$. If the forecasted reservoir volume is greater than 316,900 acre-ft $(4,163.60$ $\mathrm{ft}$ ), then the precautionary drawdown release is set equal to inflows (up to $3,000 \mathrm{ft}^{3} / \mathrm{s}$ ) until that volume forecasted to be above 316,900 acre-ft has been evacuated from storage.
Also, if precautionary drawdown releases have not been set by the logic above, when the Lahontan Reservoir volume is greater than the monthly maximum water surface-water elevation as specified in Lahontan General Filling Schedule and Release Procedures, the net inflows to the reservoir are released up to a maximum of $2,000 \mathrm{ft}^{3} / \mathrm{s}$. This monthly maximum water surface elevation ranges from $4,157.84 \mathrm{ft}$ to $4,163.67 \mathrm{ft}$.

\section{Reservoir Storage Priorities and Pass-Throughs}

A storage priority system for Truckee River reservoirs determines if a reservoir may or may not store water. This priority system is based on water storage rights. If a reservoir does not have the right to store at a given time, all inflows must be passed through that "junior" reservoir to satisfy "senior" priorities downstream. Pass-through releases are assigned to the natural water category. When a reservoir has the right and storage space to store water, it will retain all or part of the reservoir inflows. Floriston rates and Newlands Project demand for Truckee River water are parts of the storage priority system and influence reservoir storage.

\section{Storage Priorities}

Storage operations are based on decreed storage rights that necessitate a priority order for storing water in each reservoir. The following is a priority listing of target streamflows (Floriston rates) and annual reservoir storage amounts and categories that governs current reservoir storage operations (Alan Olson, Bureau of Reclamation, written commun., 1995). The first item listed has a senior right to store water, and the last item on the list cannot store water until all nine storage or streamflow demands above it have been satisfied.

When storage and streamflow demands of senior priorities are concurrently being satisfied or forecast to be satisfied, reservoirs of various storage rights may store water simultaneously as long as senior priorities continue to be met. Notable examples of this concept follow the list.

1. Donner Lake — 9,500 acre-ft storage split equally as PCPOSW and Truckee-Carson Irrigation District (TCIDPOSW). However, Donner Lake, can provide a maximum effective flood-control space of about 6,000 acre-ft (Richard D. Moser, Sierra Pacific Power Company, oral commun., 1999). 
2. Independence Lake - initial 3,000 acre-ft storage as PCPOSW (up to full lake capacity, whichever is less) with winter drawdown of about 3,000 acre- $\mathrm{ft}$ that is needed to fill in a typical year.

3. Floriston rates - target streamflows that satisfy Orr Ditch Decree (United States of America v. Orr Ditch Water Company, Equity No. A-3 (D. Nev. 1944)) diversion rights from the Truckee River except for the Truckee Canal diversion right.

4. Lake Tahoe- storage as pooled water (up to full reservoir 6,229.1 ft elevation).

5. Boca Reservoir- initial 25,000 acre-ft storage as adverse-to-canal water (up to full reservoir capacity, whichever is less).

6. Newlands Project - diversion to Truckee Canal pursuant to the Orr Ditch Decree and OCAP rights on the Newlands Project.

7. Boca Reservoir - additional 15,850 acre- $\mathrm{ft}$ storage as non-adverse-to-canal water (up to full reservoir capacity).

8. Independence Lake - additional 14,500 acre-ft storage as PCPOSW (up to full lake capacity).

9. Stampede Reservoir - 126,000 acre-ft storage as fish water (up to full reservoir capacity).

10. Prosser Creek Reservoir-30,000 acre-ft storage as uncommitted water (up to full reservoir capacity).

The Truckee River system typically is operated according to the list above. For example, if Floriston rates are not met, then Boca Reservoir is not allowed to store additional water. However, when Boca is storing the entire flow of the Little Truckee River above Boca (satisfying its demands), Prosser Creek Reservoir is allowed to store reservoir inflows so long as senior priorities (such as Floriston rates) are being met. Two exceptions to the list occur in wet years. The first exception allows Boca water to be temporarily stored in Stampede Reservoir. That stored water is then released to Boca based on instream flow and Stampede power generation demands. The second exception allows Prosser Creek Reservoir to be filled prior to the filling of senior rights if, according to forecasts, all reservoir storage and target streamflows will be satisfied in wet years and that water is not needed to meet Floriston rates or diversion to the Truckee Canal. Indepen- dence Lake is generally filled concurrently with Boca Reservoir, based on runoff projections. Any water stored in the lake in excess of the legal storage rights would be released for re-storage in Boca at a later time.

The USGS Truckee River Basin operations model simulates reservoir storage in the subblock reservoir storage priorities and pass-through requirements as follows. First, a simple forecast of the Little Truckee River inflow at the mouth is made and the forecast is used to determine whether exceptions to storage priorities can be made as described above. The forecasted inflow volume is calculated by multiplying the NRCS inflow forecast for Little Truckee River above Boca Reservoir by a drainage area ratio. On the first day of every month from January though May and again on May 31, the forecasted inflow to Boca is added to the simulated Boca storage. If the forecasted Boca Reservoir storage is greater than the reservoir capacity, then all reservoirs are filled concurrently after target streamflows are met. Otherwise, if the forecasted Boca storage is less than the reservoir capacity, the reservoirs are filled according to the storage priorities. In the latter situation, when Boca is storing the entire flow of the Little Truckee River above Boca (satisfying its demands), reservoirs with a junior right, such as Prosser Creek Reservoir, are not allowed to store reservoir inflows.

Next, using the same list of storage priorities as above, daily pass-through releases are specified on the basis of three periods and forecasted Boca Reservoir storage. The first period is during the non-filling season-January 1 to April 10 and July 16 to December 31-when inflows are assumed to be relatively small and all reservoirs are filled concurrently after target streamflows, such as meeting Floriston rates and Newlands Project demands, are met. The second period is during a normal-to-dry year when Boca is not forecasted to have excess water during filling season of April 11 to July 15. During this period, the reservoirs are filled according to the list of storage priorities. The third period is during a wet year when Boca is forecasted to have excess water during filling season of April 11 to July 15. During this period Prosser Creek Reservoir is filled concurrently with the other reservoirs. During all three periods, any pass-through releases are assigned the natural water category.

Assumptions in the reservoir storage priorities subblock include the following items. 
- The model simulates the storage of water categories as specified in the list of storage priorities for each reservoir.

- The model does not simulate the temporary storage of Boca Reservoir water in Stampede Reservoir for Stampede Reservoir optimal power generation.

\section{Reservoir Pass-Throughs and Releases to Meet Newlands Project Demands}

Storage priorities of some reservoirs upstream from Farad are influenced by demand for Truckee River water from the Newlands Project. According to the Truckee River Agreement of 1935, when the Newlands Project demand is not satisfied, a supplemental reservoir may not store water once the supplemental storage water impounded within a given year exceeds 25,000 acre-ft. The supplemental reservoir referred to in the Truckee River Agreement is Boca Reservoir, and, as discussed previously in the section "Current Water Categories," the first 25,000 acre-ft of supplemental storage water stored in the reservoir is typically referred to as adverse-to-canal water, because it can be stored adverse to Truckee Canal diversions. Truckee Canal diversions are determined by the Newlands Project demand in accordance with Operating Criteria and Procedures (OCAP) for Truckee River water and are discussed in a later section, "Truckee River Diversions to Newlands Project." Additional supplementary storage water in excess of the first 25,000 acre-ft stored in the reservoir is referred to as nonadverse-to-canal water because it cannot be stored adverse to Truckee Canal diversions. These two water categories are both types of pooled water because they are typically released to satisfy Floriston rates. Additionally, Independence Lake, with the exception of the first 3,000 acre-ft of annual storage, Stampede Reservoir, and Prosser Creek Reservoir may not store project water when Truckee Canal diversions to meet Newlands Project Demands have not been satisfied (John Simons, Bureau of Reclamation, written commun., 1991).

Inflows must "pass through" a given reservoir when Newlands Project Demands for Truckee River water are not met. Reservoir pass throughs have the same specific category as reservoir inflows, and because the water is passed through to satisfy a specific demand, the pass-through is "tagged" to the inflow category natural water. The order of reservoir pass- throughs to satisfy Newlands Project demands is shown below. It is based on storage priorities and goes from lowest priority to highest, but the order is reversed. (John Simons, Bureau of Reclamation, written commun., 1991). For instance, Prosser Creek Reservoir, the first listed item, has a low priority for storage and therefore water must pass through if Newlands Project demands are not satisfied.

1. Pass-through of natural water inflow from Prosser Creek Reservoir;

2. Pass-through of natural water inflow from Stampede Reservoir;

3. Pass-through of natural water inflow from Independence Lake after the first 3,000 acre-ft of PCPOSW has been stored;

4. Pass-through of natural water inflow from Boca Reservoir after the first 25,000 acre-ft of adverseto-canal water has been stored.

Newlands Project demands for Truckee River water are satisfied when the Lahontan Reservoir monthly storage objective is achieved and the Truckee Division demands are being served as defined by OCAP or, if the objective is not achieved and demands have not been met, when the Truckee Canal capacity of about $900 \mathrm{ft}^{3} / \mathrm{s}$ is reached. See the section "Truckee River Diversions to Newlands Project" for further discussion of Newlands Project demands.

In addition to pass-throughs of inflow from Prosser, Stampede, and Boca Reservoirs and Independence Lake, TCID may release its portion of privately owned stored water (POSW) from Donner Lake to satisfy Newlands Project demands if diversions to the Truckee Canal allowable under OCAP and the Orr Ditch Decree cannot meet the demand. Usually, the release of the category TCID privately owned stored water (TCIDPOSW) from Donner Lake is during the fall precautionary drawdown season between September and November.

The USGS Truckee River Basin operations model simulates reservoir pass-throughs to satisfy Newlands Project demands in the subblock reservoir storage priorities and pass-through requirements. (Note that a following section, "Floriston Rates," describes reservoir pass-throughs for the maintenance of Floriston rates.) The diversion rights and the status of pooled water flows diverted to the Truckee Canal in reference to these rights are defined in the subblock 
$\boldsymbol{O C A P}$. Pooled water from the Truckee River is diverted from reach 450 (upstream from Derby Dam) to the Truckee Canal, reach 61 (plate 1). If flow diverted to the canal is less than the diversion right, then the model determines the deficit, which corresponds to that additional flow of water needed to meet the diversion right. An excess is computed if pooled water at Derby Dam (reach 450, pl. 1) is more than the sum of canal diversion rights and Truckee River senior downstream water rights, the latter of which must be satisfied before water is diverted to the canal (see later section "Lower Truckee River Diversions"). The excess corresponds to the water not needed to meet Newlands Project demands and water rights downstream.

For simulation of operations, the order listed below is used to simulate pass-throughs and releases from storage for meeting the Truckee Canal diversion rights. Note that Independence Lake is not simulated to provide pass-throughs for meeting the Truckee Canal demand because it is only rarely used in current practice (Jeff Boyer, U.S. District Court Water Master, oral commun., 1997).

1. Pass-through of natural water inflow from Prosser Creek Reservoir;

2. Pass-through of natural water inflow from Stampede Reservoir;

3. Pass-through of natural water inflow from Boca Reservoir after the first 25,000 acre-ft of adverseto-canal water has been stored;

4. Release of TCID water from Donner Lake (from September 1 to November 15).

The subblock reservoir storage priorities and pass-through requirements uses the deficit or excess value determined previously to appropriately adjust simulated pass-throughs and releases from the previous time interval. If the Newlands Project demand cannot be met by natural water from unregulated tributary basins and reservoir pass-throughs and releases, then that quantity of natural water needed to meet the demand cannot be stored in Prosser Creek, Stampede, and Boca Reservoirs. Natural water inflow to Martis Creek Lake is usually not stored except for floodcontrol operations. For simulations, natural water inflow needed to meet Newlands Project demands is passed through Prosser Creek Reservoir first. If the diversion right cannot be met after inflow has passed through Prosser Creek, then Stampede cannot store natural water inflow and must pass through its inflow. However, unlike Prosser Creek and Boca passthroughs, simulated Stampede pass-throughs do not necessarily reduce the deficit because Stampede passthroughs may be stored in Boca. For Boca, if the first 25,000 acre-ft of water has been stored adverse-tocanal in a given year, additional natural water inflow cannot be stored, and all or part of this inflow must pass through until the Truckee Canal diversion right has been met. Lastly, if pass-through from Prosser Creek, Stampede, and Boca Reservoirs cannot meet the canal diversion right, TCIDPOSW water will be released from Donner Lake if the date is between September 1 and November 15. This period is just after the recreation season and generally coincides with a period of precautionary drawdowns to maintain flood-control space in the lake.

If the flow of pooled water at Derby Dam exceeds Newlands Project demands and senior downstream water rights, the releases and pass-throughs of inflow are reduced accordingly in the opposite order of that specified above insofar as flood-control criteria will allow.

For simulations, only pooled water is diverted to the Truckee Canal for the Newlands Project. Therefore, the natural water that passes through the reservoirs and TCIDPOSW water released from Donner Lake are converted to pooled water just upstream from Derby Dam.

For simulations, it is assumed that reservoir passthroughs and releases are made according to an established priority. Simulations of pass-throughs for Newlands Project demands do not attempt to coordinate with pass-throughs from other reservoirs to benefit other uses.

\section{Reservoir Demands}

Under existing operations, several demands are described in legal decrees that are satisfied using reservoir releases and river diversions: Floriston rates, instream flows, Pyramid Lake fish, and POSW demands to satisfy M\&I and irrigation water rights.

\section{Floriston Rates}

Floriston rates, described in the previous section "Chronology and Background of Decrees, Agreements, and Laws Affecting Operation," are minimum-flow criteria for the Truckee River at the California-Nevada boundary and constitute the chief operational objective 
for the river (table 2). When flow rates measured at the USGS gaging station near Farad, Calif., meet Floriston rates, all agricultural, M\&I, and hydropower water rights under the Orr Ditch Decree are assumed to be satisfied, except for Newlands Project demands.

According to the Truckee River Agreement of 1935, when Floriston rates are not met by the natural flow of the river, pooled water stored in Lake Tahoe and Boca Reservoir may be released to eliminate any deficit. The agreement specified priorities of reservoir release to attain Floriston rates when natural water in the river, alone, cannot maintain the rates. The major use of pooled water in Lake Tahoe is for maintenance of Floriston rates. Pooled water stored in the Boca Reservoir is also released for Floriston rates. The timing of the Boca pooled water release depends on when the water was stored and if it was stored adversely to Truckee Canal diversion rights. Additionally, between April 1 and October 31 of any given year, the reservoir used for Floriston rates depends on the water-surface elevation of Lake Tahoe (table 2). If the water-surface elevation is greater than $6,225.5 \mathrm{ft}$, then releases of Tahoe pooled water are minimized while releases of pooled water from Boca are maximized. If Boca releases of pooled water are insufficient to maintain Floriston rates, then additional pooled water will be released from the lake. If the water-surface elevation of the lake is less than or equal to $6,225.5 \mathrm{ft}$ between April 1 and October 31, then releases of pooled water from the lake are used to maintain Floriston rates. If the pooled water release from the lake is insufficient to maintain rates, then pooled water from Boca will be released.

Prosser Creek Reservoir, completed in 1962, provides another storage source from which to achieve Floriston rates. Uncommitted water is the project water stored in the reservoir. In accordance with the TahoeProsser Exchange Agreement of 1959, Prosser uncommitted water may be exchanged to a water category called Tahoe-Prosser Exchange water (TPEW) if releases of pooled water are made from Lake Tahoe to meet minimum instream flows rather than to meet Floriston rates. TPEW stored in Prosser Creek Reservoir through the Tahoe-Prosser Exchange Agreement can later be used as though it were Lake Tahoe pooledwater storage to maintain Floriston rates.

The Truckee River Agreement and other legal decrees and informal conventions or arrangements specify the order of reservoir releases to maintain Floriston rates assigned to the four water categories:
(1) pooled water in Lake Tahoe, (2) adverse-to-canal water in Boca Reservoir, (3) non-adverse-to-canal water in Boca Reservoir, and (4) TPEW in Prosser Creek Reservoir. The adverse-to-canal and nonadverse-to-canal water categories in Boca are both pooled water, but are differentiated by whether the pooled water was or was not stored adverse to Truckee Canal diversion rights. Adverse-to-canal water is the first 25,000 acre- $\mathrm{ft}$ of pooled water stored in Boca and has a higher storage priority than water diverted to the Truckee Canal. Non-adverse-to-canal water is the additional storage of pooled water and has a lower storage priority than water diverted to the canal. In current practice, reservoir releases to maintain Floriston rates are not necessarily made sequentially (one at a time), but are commonly blended from more than one reservoir to satisfy other operational objectives. Recreational objectives are also considered in current operational practices when assigning orders to reservoir releases for Floriston rates. Recreational objectives include maintaining minimum storage levels that enhance activities such as boating and fishing.

Although Donner Lake is the only reservoir that has a legal recreational pool, Prosser Creek and Boca Reservoirs may be operated to provide recreational pools.

The USGS Truckee River Basin operations model simulates the maintenance of Floriston rates as follows. First, in the subblock initial assignments and computations, the status of flow at the Farad gaging station (reach 240) is defined in reference to Floriston rates. The categories natural water flow and pooled water flow are added, and that sum, hereafter in this discussion called pooled water, is compared with target rates as defined in table 2 . If the summed pooled water flow is less than the target rates, then the deficit is determined to be that additional flow of water needed to maintain the rates. Likewise, if the summed pooled water flow is more than the target rates, the excess is determined to be that amount of pooled water not needed to maintain the rates.

The following list is the order of water categories and sources used to maintain Floriston rates. A more detailed description follows the list.

1. Natural water inflows from unregulated tributary subbasins (sidewater).

2. Pass-through of natural water inflow from Prosser Creek Reservoir. 
3. Pass-through of natural water inflow from Stampede Reservoir.

4. Pass-through of natural water inflow from Boca Reservoir.

5. Release of pooled water from Lake Tahoe if:

a. Flow just downstream from the lake does not meet the minimum instream flow target.

b. The date is between April 1 and October 31 and if the water surface elevation is between 6,223.0 (outlet rim) and 6,225.5 ft, or

c. The date is between November 1 and March 31.

6. Release of Tahoe-Prosser Exchange water from Prosser Creek Reservoir if:

a. The date is between April 1 and September 3 (recreation season) and if total reservoir water volume is greater than or equal to 19,000 acre-ft (recreation volume threshold), or

b. The date is between September 4 and March 31.

7. Release of adverse-to-canal water from Boca Reservoir.

8. Release of non-adverse-to-canal water from Boca Reservoir.

9. Release of Tahoe-Prosser Exchange water from Prosser Creek if the date is between April 1 and September 3 and if total reservoir water volume is less than 19,000 acre-ft.

10. Release of pooled water from Lake Tahoe if the date is between April 1 and October 31 and if the water surface elevation is greater than $6,225.5 \mathrm{ft}$.

The subblock maintenance of Floriston rates, uses the deficit and excess determined previously to appropriately adjust releases from the previous time interval to maintain rates for the current interval. If sidewater, reservoir pass-throughs of natural water, and reservoir releases from the previous time interval cannot maintain rates for the current time interval, then a deficit exists, and that quantity of natural water inflow to Prosser Creek, Stampede, and Boca Reservoirs needed to eliminate the deficit cannot be stored, and thus must pass through that reservoir. Natural water inflows to Martis Creek Lake are usually released, except when they are stored for flood-control operations. As previously discussed in the section "Storage Priorities," only up to 3,000 acre-ft of Independence Lake inflow may be stored adverse to Floriston rates. However, for simulations it is assumed that the lake is not operated to provide pass-throughs for meeting Floriston rates because it is only rarely used in current practice. Donner Lake inflow, however, may be stored adverse to Floriston rates. Inflow to Lake Tahoe is considered pooled water for model simulations and, as discussed earlier, will be released as necessary to maintain Floriston rates. For simulations, natural water inflows needed to make rates are passed through Prosser Creek Reservoir first, Stampede Reservoir second, and Boca Reservoir third. The order is assumed on the basis of storage priorities specified by reservoir storage rights (Jeff Boyer, U.S. District Court Water Master, oral commun., 1994).

If Floriston rates cannot be met after inflows have passed through Prosser Creek, Stampede, and Boca Reservoirs, then releases of stored water must be made from Lake Tahoe, Prosser, or Boca. The first choice for release is pooled water from Lake Tahoe if (1) additional releases are also needed to maintain minimumflow targets just downstream from the lake, (2) if date is between April 1 and October 31 and if the water-surface elevation is between $6,223.0 \mathrm{ft}$ (the rim) and 6,225.5 ft, or (3) the date is between November 1 and March 31. Minimum-flow targets just downstream from Tahoe are specified as $50 \mathrm{ft}^{3} / \mathrm{s}$ between October 1 and March 31, and $70 \mathrm{ft}^{3} / \mathrm{s}$ for the remainder of the year, as described in the subsequent section "Minimum Instream Flows."

If pooled water releases from Lake Tahoe are not adequate to maintain Floriston rates, then TahoeProsser Exchange water (TPEW) from Prosser Creek Reservoir is the next priority for release, depending on recreational objectives. For simulations, the recreational season is defined between the dates April 1 and September 3. If the date is outside of the recreational season or if the date is within the recreational season and water volume in Prosser is greater than the recreational volume threshold (19,000 acre-ft), then TPEW is considered for release to maintain Floriston rates (Jeff Boyer, U.S. District Court Water Master, oral commun., 1994). 
If pooled water releases from Lake Tahoe and TPEW from Prosser are not adequate to maintain Floriston rates, then pooled water releases from Boca, as adverse-to-canal water and non-adverse-to-canal water (in that order) are the next priorities for release.

After Boca Reservoir, the next priority for release is from TPEW from Prosser Creek Reservoir (1) if the volume of the reservoir is less than the recreational threshold of 19,000 acre-ft and (2) if the date is within the reservoir recreational season.

Finally, if all appropriate water categories are not available to maintain Floriston rates under the conditions stated above, pooled water is released from Lake Tahoe if the water-surface elevation of the lake is above $6,225.5 \mathrm{ft}$ and if the date is between April 1 and October 31 . When natural water flows in the Truckee River are low and volumes of the appropriate water categories in the lake and Prosser and Boca Reservoirs are inadequate to maintain rates during drought periods, rates of pooled water and natural water flow at the Farad gaging station may be less than Floriston rates.

If Floriston rates are exceeded, then releases and pass-throughs of inflow are reduced accordingly in the opposite order specified above. Rates of pooled water and natural water flow at the Farad gaging station commonly exceed Floriston rates during periods of high water, such as during the spring snowmelt season or during large storm events in the winter and spring. During these conditions, even though reservoir releases may be reduced to zero, inflows to the Truckee River from sidewater or natural water inflows passed through reservoirs in accordance with flood-control criteria, may be large enough to exceed the rates. However, the goal of the subblock maintenance of Floriston rates is to maintain pooled water and natural water flows at the Farad gaging station as close as possible to Floriston rates.

Several assumptions were used in the model code development for simulation of Floriston rates.

- Similar to the simulation of reservoir passthroughs for Newlands Project demands, Independence Lake is not simulated to provide passthroughs specifically for the maintenance of Floriston rates. In current practice, it is not commonly operated to meet rates.

- No volume objective for recreation is considered for Boca Reservoir when computing releases for Floriston rates. However, elsewhere in the model code, as described in the related draft TROA sec- tion "Voluntary Exchanges," recreational threshold volumes of Boca are considered.

- Reservoir releases are simulated by rank order. Simulations of releases for Floriston rates do not attempt to combine reservoir releases from more than one reservoir to optimize other objectives.

However, in the code simulating draft TROA and WQSA operations as described later in this report, water categories are exchanged and releases amongst reservoirs are blended to meet multiple objectives such as storage of credit waters, attaining enhanced and preferred flows, maintaining reservoir recreational volumes, and storage of water categories for enhanced storage security in preferred reservoirs. Such exchanges may result in releases for Floriston rates from more than one reservoir.

- The specified order of reservoir pass-through of inflows for Prosser Creek, Stampede, and Boca Reservoirs is based on reservoir storage priorities. It was assumed that pass-through of inflows would be in the opposite order of storage priorities.

- The specified orders of reservoir releases for Lake Tahoe, and Boca and Prosser Creek Reservoirs were partially assumed because Prosser was completed more than 25 years after the Truckee River Agreement specified orders of release for Lake Tahoe and the supplemental reservoir, Boca. Additionally, in the simulation of adverse- and non-adverse-to-canal releases from Boca, dates of storage of these waters, as described in the Truckee River Agreement were not considered. Instead, adverse-to-canal water was assumed to be released prior to non-adverse-to-canal water.

- Net inflow to Lake Tahoe is considered pooled water rather than natural water for model simulations. Therefore, pass-throughs for maintenance of Floriston rates are not simulated for Tahoe.

\section{Minimum Instream Flows}

Several reservoirs in the Truckee River Basin are operated to provide releases necessary to maintain minimum instream flows just downstream from the reservoirs. The following list describes minimum instream flows for each reservoir. 


\section{Lake Tahoe}

The Tahoe-Prosser Exchange Agreement of 1959 requires releases from Lake Tahoe pooled water storage to maintain minimum instream flows just downstream from the lake during periods when a release from storage would otherwise not be required to maintain such flows. The agreement requires a minimum instream flow below the lake of $50 \mathrm{ft}^{3} / \mathrm{s}$ between October 1 and March 31 and a flow of $70 \mathrm{ft}^{3} / \mathrm{s}$ for the remainder of the year if that same amount of water can be exchanged to Tahoe-Prosser Exchange water (TPEW) in Prosser Creek Reservoir from storage of Prosser inflow that would otherwise pass through the reservoir or from previously stored uncommitted water. Uncommitted water in Prosser is water already in storage, but TPEW is only created by the TahoeProsser Exchange. Thus, the availability of uncommitted water for exchange in Prosser may limit Lake Tahoe releases to maintain instream flows.

\section{Donner Lake}

Releases are made to maintain a minimum instream flow downstream from the lake of $2 \mathrm{ft}^{3} / \mathrm{s}$ when the flow immediately below the confluence with Cold Creek is $5 \mathrm{ft}^{3} / \mathrm{s}$ or more. Otherwise, the minimum instream flow is $3 \mathrm{ft}^{3} / \mathrm{s}$. Between November 15 and April 15, the upper two gates of the dam must be held open and, as a result, instream flows are governed by inflows to the lake. According to the Donner Lake Indenture of 1943, water cannot be released from the lake if the water surface elevation is lower than $5,932.0 \mathrm{ft}$ and the date is between June 1 and August 31 .

\section{Martis Creek Lake}

No minimum instream flow requirements exist downstream from Martis Creek Lake.

\section{Prosser Creek Reservoir}

Releases are made to maintain a minimum instream flow downstream from Prosser of $5 \mathrm{ft}^{3} / \mathrm{s}$ or inflow to the reservoir, whichever is less.

\section{Independence Lake}

Releases are made to maintain a minimum instream flow downstream from the lake of $2 \mathrm{ft}^{3} / \mathrm{s}$.

\section{Stampede Reservoir}

Releases are made to maintain a minimum instream flow downstream from Stampede of $30 \mathrm{ft}^{3} / \mathrm{s}$. These releases may be re-stored in Boca if allowed in conformance to storage rules.

\section{Boca Reservoir}

No minimum instream flow requirements exist downstream from Boca Reservoir.

The USGS Truckee River Basin operations model simulates reservoir releases to maintain minimum instream flows in four subblocks. The subblock initial assignments and computations assigns proposed releases from each reservoir to maintain instream minimum flows. The subblock reservoir releases to meet minimum flows modifies the proposed releases by applying various rules and constraints for all reservoirs required to release for minimum flows except Lake Tahoe. The subblock merge then compares proposed untagged releases for minimum flows to other proposed releases that are tagged, such as tagged releases of pooled water to meet Floriston rates. As previously discussed in the section "Description and Simulation of Truckee River Basin Operations," the merge subblock assigns water categories for those proposed untagged releases for minimum flows. For Lake Tahoe, pooled water releases for minimum flows are simulated by the Tahoe-Prosser Exchange logic in the subblock current exchanges.

Proposed releases from Donner Lake to maintain minimum flows are set to $3 \mathrm{ft}^{3} / \mathrm{s}$ in the subblock initial assignments and computations. Although required releases may be reduced from $3 \mathrm{ft}^{3} / \mathrm{s}$ to $2 \mathrm{ft}^{3} / \mathrm{s}$ depending on Donner Creek flow downstream from Cold Creek, for model simulations, flow data are not available to determine such a reduction. Model code in the subblock reservoir releases to meet minimum flows limits the proposed release to the outlet capacity of the dam for the current water surface elevation, and if the current water surface elevation of the lake is less than 5,932.0 ft between June 1 and August 31, reduces the proposed release to zero. Model code in the subblock 
merge compares the proposed release to other tagged releases for assignment of water categories to the release.

Proposed releases to maintain minimum flows from Prosser Creek Reservoir, Independence Lake, and Stampede Reservoir are set to 5, 2, and $30 \mathrm{ft}^{3} / \mathrm{s}$, respectively, in the subblock initial assignments and computations. For these reservoirs, model code in the subblock reservoir releases to meet minimum flows limits the proposed releases to the outlet capacity of the dams for the current water surface elevation and, for Prosser, the inflow to the reservoir. As for Donner Lake, model code in the subblock merge compares the proposed releases to other tagged releases for assignment of water categories to the releases.

Proposed pooled water releases from Lake Tahoe to maintain minimum flows are set to $50 \mathrm{ft}^{3} / \mathrm{s}$ between October 1 and March 31 and $70 \mathrm{ft}^{3} / \mathrm{s}$ for the remainder of the year. In the model code that simulates the TahoeProsser Exchange in the subblock current exchanges, the proposed minimum-flow release from the lake is limited to the storage of Prosser Creek Reservoir inflow that would otherwise pass through the reservoir or from previously stored uncommitted water available for exchange to Tahoe-Prosser Exchange water in the reservoir (see subsequent section, "Tahoe-Prosser Exchange"). Use of the subblock merge is not necessary because releases for minimum flows from Lake Tahoe are tagged as pooled water. A user option may allow the minimum flow to be set equal to the flow needed for rafting activities, about $200 \mathrm{ft}^{3} / \mathrm{s}$.

\section{Pyramid Lake Fish}

Because cui-ui and Lahontan cutthroat trout in Pyramid Lake are listed as endangered and threatened species, respectively, under the ESA, the Department of the Interior is responsible for the recovery of these species. Several plans to accomplish the recovery of these species have been developed (Strekal and others, 1992; Buchanan and Strekal, 1988) and management activities and species response to environmental conditions have been documented (Heki, 1994, and Heki and Cowan, 1994). These plans include goals of providing optimal spawning habitat and providing upstream storage of water for later release during times when fish spawn.

An important objective for fish recovery is to provide spawning habitat. Cui-ui spawn in the lower Truckee River, typically between March and July depending on river flow and access to the river. Spawning and development of eggs and larvae are affected by water depth, velocity, temperature, and quality. Spawning and rearing factors are largely functions of the lower Truckee River flow during certain times of the year, which is affected by reservoir storage and releases, diversions, and natural and return flows to the river downstream from reservoirs. Biologists have developed procedures to promote spawning and recruitment by regulating the flow of the lower Truckee River (Strekal and others, 1992, Buchanan and Strekal, 1988). These procedures establish flow regimes and cui-ui flow targets at Truckee River near Nixon (hereafter referred to as the Nixon gaging station) based on water availability and management options. Although flows are currently managed to encourage cottonwood growth for shade along the lower Truckee River, no formal criteria have been established that could be incorporated into the model code. In addition, no flow management strategy has been developed yet for Lahontan cutthroat trout.

Flow regimes can be defined according to the level or timing of spawning activity for a given spring runoff season. Flow regimes have been separated into four groups: (1) full spawning with early (mid-June) completion, sometimes referred to as a "fish run," (2) reduced spawning to allow for human collection of eggs, (3) no spawning, or (4) full spawning with late (mid-July) completion. Flow regimes are based on the forecasted Pyramid Lake level, "attraction flows" at Pyramid Lake, water volume available for spawning, and the time of the year. Attraction flows are defined by the average Truckee River discharge into Pyramid Lake from January to April of a spawning season which, if sufficient, may serve as a stimulus to initiate a spawning run (Buchanan and Strekal, 1988, p. C-2). Cui-ui flow targets are set on the basis of the flow regime (table 4) and maximum flows (up to 2,500 $\mathrm{ft}^{3} / \mathrm{s}$ ) during a spawning season at the Nixon gaging station. As flow targets vary, changes in flow are smoothed or "ramped" gradually, such that large changes between daily flows are minimized.

A related objective for fish recovery is to provide storage of water in Truckee River Basin reservoirs for spawning. The judgement Carson-Truckee Water Conservancy District $v$. Watt, 1982 requires all project water in Stampede Reservoir to be for the benefit of Pyramid Lake fishes. Uncommitted water stored in Prosser Creek Reservoir in excess of storage under the 
Tahoe-Prosser Exchange Agreement also has been reserved (Bureau of Reclamation, 1959) to provide water for release to Pyramid Lake for spawning habitat.

Current Pyramid Lake fish operations are used to manage the water available for spawning flows at Nixon gaging station, based on the (1) determination of flow regimes and cui-ui flow targets, (2) demand forecast and inflow forecasts, and reservoir storage rights, and (3) fish water available in Stampede and Prosser Creek Reservoirs.

Large releases from Boca Reservoir are sometimes necessary to satisfy Pyramid Lake fish flow targets. Hydraulic constraints of the outlet structure at Boca require commitment of additional stored waters used to maintain Boca stages sufficient to attain these large releases. This temporarily stored water in Boca is called Boca pressure water. Boca pressure water is delivered to Boca Reservoir from Stampede Reservoir during full spawning regimes from about April 1 to May 30 (Garry Stone, U.S. District Court Water Master, oral commun., 1996). The Boca stage necessary for Boca pressure water is about $5,560.6 \mathrm{ft}$. $(9,000$ acre-ft), which is the hydraulic head necessary to release $1,000 \mathrm{ft}^{3} / \mathrm{s}$, or about 2,000 acre- $\mathrm{ft} / \mathrm{d}$, through the outlet works. Fish water from Stampede Reservoir is used to maintain Boca pressure water targets (Chester Buchanan, U.S. Fish and Wildlife Service, written commun, 1997) and instream flows.

The USGS Truckee River Basin operations model simulates Pyramid Lake fish operations in the subblock as follows: (1) initial numerical assignments and computations are made, (2) the amount of water available for fish operations is computed, (3) the flow regime and cui-ui flow targets are determined, (4) releases of stored fish water from Truckee River Basin reservoirs are determined to maintain cui-ui flow targets, and (5) releases from Stampede Reservoir are determined to maintain Boca pressure water.

First, cui-ui flow targets are set equal to targets described by the recovery plans (Strekal and others, 1992; Buchanan and Strekal, 1988). Other assignments that are used in simulations of Pyramid Lake fish operations include the following items: (1) "attraction flow" accumulator at reach 540 (near Nixon) is reset to zero on January 1, and (2) maximum flow accumulator at reach 540 is reset to zero on January 1 . The maximum flow accumulator is limited to $2,500 \mathrm{ft}^{3} / \mathrm{s}$. These items are discussed below in the text.
After initial numerical assignments and computations are made, the amount of water available for Pyramid Lake fish operations is computed in the subblock Pyramid Lake fish operations. This amount includes existing storage of fish waters in reservoirs plus forecasted inflow to the Truckee River Basin minus forecasted demands for serving Orr Ditch rights and Newlands Project demands, minus forecasted senior rights in upstream reservoirs for reservoir storage minus allowance for 10,000 acre-ft in Prosser Creek Reservoir and 50,000 acre-ft in Stampede Reservoir (Alan Olson, Bureau of Reclamation, oral commun., 1996).

Next, the flow regime and cui-ui flow targets are determined. Flow regimes are determined on January 1, March 1, April 1, May 1, and August 1 on the basis of the Pyramid Lake level, attraction flow accumulator at Nixon, water volume available for spawning, and the month. As discussed previously, theoretical flow regimes have been separated into four groups: (1) full spawning with early (mid-June) completion, (2) reduced spawning to allow for human collection of eggs, (3) no spawning, and (4) full spawning run with later completion. Flow regime 4 was not simulated because it was not likely to occur in actual operations (Chester Buchanan, USFWS, oral commun., 1997). On the basis of the cui-ui flow regime, the cuiui flow target (table 4) is specified as a flow at Nixon gaging station (reach 540). The targets vary according to date, flow regime, total attraction flow, and maximum flow at reach 540 since January 1. Ramping between cui-ui flow targets is simulated by varying flow targets gradually in the model by about $95 \mathrm{ft}^{3} / \mathrm{s}$ per day.

Next, the model determines releases from Truckee River Basin reservoirs for the maintenance of cui-ui flow targets at Nixon gaging station. The amount of water available for Pyramid Lake fish operations is compared to the cui-ui flow target at reach 540. If the available flow is less than the target, then a deficit is determined as that additional flow of water needed to achieve the target. Likewise, if the available flow is greater than the target, an excess is determined as the amount of available cui-ui flow not needed to maintain targets.

The following are the current water categories and sources used to maintain cui-ui flow targets (Chester Buchanan, U.S. Fish and Wildlife Service, written commun, 1997). 
Table 4. Fish flow targets to optimize spawning success by regulation of flows at Truckee River near Nixon, Nevada (from Strekal and others, 1992, and Buchanan and Strekal, 1988)

[Symbol: >, greater than]

\begin{tabular}{|c|c|c|c|c|}
\hline & \multicolumn{4}{|c|}{$\begin{array}{l}\text { Fish flow targets at the Truckee River near Nixon gaging station } \\
\text { (cubic feet per second) }\end{array}$} \\
\hline & Flow regime 1 & Flow regime 2 & Flow regime 3 & Flow regime 4 \\
\hline January & 90 & 50 & 0 & 90 \\
\hline February & 120 & 50 & 0 & 120 \\
\hline March & 190 & 50 & 0 & 190 \\
\hline April & ${ }^{1} 570$ & 50 & 0 & ${ }^{1} 570$ \\
\hline May & $1,2>1,000$ & 150 & 0 & $1,2>1,000$ \\
\hline June & ${ }^{3} 50$ & 0 & 0 & $1,2>1,000$ \\
\hline July & 0 & 0 & 0 & ${ }^{4} 50$ \\
\hline August & 0 & 0 & 0 & 0 \\
\hline September & 0 & 0 & 0 & 0 \\
\hline October & 0 & 0 & 0 & 0 \\
\hline November & 0 & 0 & 0 & 0 \\
\hline December & 0 & 0 & 0 & 0 \\
\hline
\end{tabular}

\footnotetext{
${ }^{1}$ Transition between fish flow targets are changed or "ramped" such that daily change in flows are 95 cubic feet per second.

${ }^{2}$ Fish flow target equals maximum simulated daily streamflow at reach 540 but does not exceed 2,500 cubic feet per second.

${ }^{3}$ Fish flow targets are ramped down to 50 cubic feet per second by June 30 .

${ }^{4}$ Fish flow targets are ramped down to 50 cubic feet per second by July 31.
}

1. Boca Reservoir fish water (from Stampede Reservoir). The delivery of Pyramid Lake fish water from Stampede through Boca is described later in this section.

2. Prosser Creek Reservoir uncommitted water.

The subblock Pyramid Lake fish operations uses the simulated deficit or excess computation to adjust releases every third day to allow for travel time to reach 540 from upstream reservoirs. If the cui-ui flow target is not being met by available cui-ui flow, then additional releases of stored fish water must be made from Truckee River Basin reservoirs in the order specified above. If existing cui-ui flow targets are exceeded, then reservoir releases are reduced accordingly in the opposite order specified above.

The following discussion describes how the operations model simulates the maintenance of Boca pressure water volume for current operations. Boca pressure water is delivered to Boca Reservoir from Stampede Reservoir in the model during flow regime 1 from March 1 to June 5. The status of existing fish water storage and total stage in Boca is compared to the Boca pressure water targets of 2,000 acre- $\mathrm{ft}$ and 5,560.6 feet, respectively. If either the simulated Boca fish water storage or elevation is less than the target, then the deficit is determined as that additional volume of water needed for storage in Boca to maintain the volume of Boca pressure water targets. Fish water released from Stampede is used to maintain Boca pressure water targets.

The following assumptions were used in the model code to simulate the Pyramid Lake fish operations.

- A tolerance of $10 \mathrm{ft}^{3} / \mathrm{s}$ is used to determine when Pyramid Lake fish releases from upstream reservoirs Boca or Prosser are necessary. If Nixon flows are within $10 \mathrm{ft}^{3} / \mathrm{s}$ of the targets, no additional releases are made. This tolerance may be modified by the user.

- Operations to promote the growth of cottonwood trees along the lower Truckee River corridor were not included because the hydrograph recession guidelines provided by the U.S. Fish and Wildlife Service (Lisa Heki, written commun., 1997) fell 
within the cui-ui spawning flow recession and thus would be superseded by them.

\section{Privately Owned Stored Water}

Privately owned stored water (POSW) is defined as water owned by the Power Company (PCPOSW) or TCID (TCIDPOSW). PCPOSW water is established and typically stored in Donner and Independence Lakes. However, under certain conditions PCPOSW may also be stored in Stampede and Boca Reservoirs. TCIDPOSW is established and stored in Donner Lake. Hereafter, reservoir and river operations regarding PCPOSW and other water rights owned by the Power Company will be called "Power Company operations" and those operations regarding TCIDPOSW in Donner Lake will be called "Truckee-Carson Irrigation District operations."

Current Power Company operations use guidelines based on decrees and rulings, inflow forecasts, current runoff conditions, and reservoir storage to determine a strategy for satisfying M\&I demands (Richard D. Moser, Sierra Pacific Power Company, written commun., 1995). Power Company water supplies consist of ground-water and surface-water resources. Power Company ground-water supplies are pumped from wells throughout the Truckee Meadows. Use of the ground-water supplies is spatially and temporally distributed in a given year. The monthly distribution of ground-water pumpage for 1995 has been provided by the Power Company (Richard D. Moser, Sierra Pacific Power Company, written commun., 1995). The maximum annual ground-water pumpage for M\&I is based on forecasted and actual runoff conditions (Richard D. Moser, Sierra Pacific Power Company, oral commun., 1995). Power Company surfacewater supplies can be separated into two groups: Power Company water originating from reservoir storage of POSW and Power Company water originating from river sources.

Power Company water originating from reservoir storage rights currently includes PCPOSW in Donner and Independence Lakes, and recent agreements have allowed the Power Company to store additional PCPOSW in Boca and Stampede Reservoirs for power generation and M\&I supplies during droughts. In the Truckee River Agreement, the Power Company is allowed to consistently store up to 800 acre-ft of PCPOSW in Boca Reservoir (called Boca pondage). This volume of water allows the Power Company to store PCPOSW in Boca for use in regulating flow for power generation and meeting Floriston rates. The Interim Storage Agreement (Bureau of Reclamation, 1994) allows the Power Company to store PCPOSW (called contract storage) in Stampede and Boca Reservoirs. The agreement is intended to provide additional storage capacity for SPPC to meet domestic, municipal, and industrial demands in Truckee Meadows during drought years. Also, the agreement stipulates that any PCPOSW stored above 5,000 acre-ft in Stampede and Boca Reservoirs above the Boca pondage be exchanged to fish water on September 1.

PCPOSW released from Independence and Donner Lakes (see the section "Donner-Boca Exchange," under "Current Operational Exchanges") and Stampede Reservoir during summer and fall precautionary releases and to meet enhanced flows from Stampede are used to fill the contract storage. When TROA is finalized, the Interim Storage Agreement will be nullified.

Independence Lake is informally operated with consideration of minimum pool of 7,500 acre- $\mathrm{ft}$ for Lahontan cutthroat trout access to spawning habitat upstream from the lake (Richard D. Moser, Sierra Pacific Power Company, written commun., 1995).

The Power Company's water supply originating from river sources is defined by the Truckee River Agreement of 1935 and Orr Ditch Decree (United States of America v. Orr Ditch Water Company, Equity No. A-3 (D. Nev. 1944)). These documents provide rules and priorities for the allocation of Truckee River water to Truckee Meadows water-rights downstream from the Farad gaging station (see section "Truckee Meadows Diversions." The Truckee River Agreement specifies that the Power Company shall have the right to the first $40 \mathrm{ft}^{3} / \mathrm{s}$ of pooled water in the Truckee River at Farad (Truckee River Agreement, p. 7). Additionally, the Power Company has been purchasing agricultural water rights defined by the Orr Ditch Decree and converting them to M\&I water rights. Current (1991) converted water rights are defined in a FWM table "Truckee Meadows Priorities" (Jeff Boyer, U.S. District Court Water Master, written commun., 1994). The Truckee River Agreement of 1935 also specifies that the Power Company has the right to the first $13.6 \mathrm{ft}^{3} / \mathrm{s}$ of water in Hunter Creek, which is also used as a M\&I water right.

Determination of Power Company demands is based on historical patterns of M\&I water use and population (Richard D. Moser, Sierra Pacific Power Com- 
pany, oral commun., 1995). The Power Company historically has diverted water to five treatment plants -Glendale, Chalk Bluff, Highland, Hunter, and Idlewild. As of 1995, diversions are only being made to the Glendale and Chalk Bluff plants; Highland, Hunter and Idlewild have been retired. Meeting the demands is based on available surface- and ground-water supplies and availability and limits of surface-water treatment capacity. Ground-water use is maximized in a drought in order to conserve surface-water supplies (Richard D. Moser, Sierra Pacific Power Company, oral commun., 1999). Surface-water supplies stored in a reservoir may be carried over from one year to the next.

The USGS Truckee River Basin operations model simulates Power Company operations by first making numerical assignments and computations are made to determine Power Company M\&I demands and location of M\&I diversions. Logic in the subblock Power Company operations is used to determine: (1) PCPOSW originating from reservoir storage and water originating from the Orr Ditch Decree, (2) M\&I diversions amounts, (3) Boca Reservoir storage of PCPOSW, and (4) reservoir storage of PCPOSW according to the Interim Storage Agreement.

First, in the subblock initial assignments and computations, three options were developed to determine the Power Company M\&I demands. The first option uses the rate of population growth from 1995 to determine the M\&I demand. A user-defined variable incrementally changes the 1995 M\&I demand prior to and subsequent to 1995 , assuming a constant relation between population and M\&I demand. This demand changes every year, based on the assumption of constant percentage growth of population. The second option uses historical M\&I demands from the Power Company for 1977-97. The third option uses a constant M\&I demand pattern (currently set at the 1995 demand pattern) from the Power Company for all years of a simulation run. In all three options, the model diverts M\&I water to two treatment plants-Chalk Bluff and Glendale plants - using a fixed monthly distribution to the plants based on historic diversions for 1995-97.

Other computations include the following items.

- Determination of the maximum annual groundwater pumpage for M\&I is based on whether the forecasted runoff index designation is computed to be normal, wet, or dry (see the section "Runoff Index," under the section "Forecasts Affecting Operational Decisions"). Once the annual amount is determined, monthly supplies from ground water are computed on the basis of historical pumpage data for normal, wet, or dry years in the Truckee Meadows area (Richard D. Moser, Sierra Pacific Power Company, written commun, 1995).

- A tolerance of $5.0 \mathrm{ft}^{3} / \mathrm{s}$ is used to determine when the PCPOSW releases are necessary. If releases are within $5.0 \mathrm{ft}^{3} / \mathrm{s}$ of targets, no additional releases are made.

Next, M\&I sources are determined in the subblock Power Company operations. First, all groundwater and surface-water M\&I supplies are summed. This sum includes M\&I surface-water supplies originating from river rights (as determined in the section “Truckee Meadows Diversions"), Hunter Creek M\&I supplies, current PCPOSW releases from Truckee River Basin reservoirs, and ground-water M\&I supplies. If the supplies are less than the demands, then the deficit is determined as that additional flow of water needed to satisfy M\&I demands. Likewise, if the supplies are more than the demands, the excess is determined to be that water not needed to maintain $M \& I$ demands.

The following list identifies the surface-water sources used to satisfy M\&I demands in the Truckee Meadows. Specific ground-water sources are not simulated by the model.

- First $40 \mathrm{ft}^{3} / \mathrm{s}$ of Truckee River pooled water and first $13.6 \mathrm{ft}^{3} / \mathrm{s}$ of Hunter Creek streamflow per Truckee River Agreement.

- Available Orr Ditch Decree (United States of America v. Orr Ditch Water Company, Equity No. A-3 (D. Nev. 1944)) agricultural rights flowing in the Truckee River converted to M\&I rights (see section “Truckee Meadows Diversions”).

- Release of PCPOSW from Boca Reservoir. PCPOSW in Boca originates from Stampede Reservoir or Independence Lake.

- Release of PCPOSW from Donner Lake if the date is between April 1 and August 31 and if the lake elevation is above 5,932.0 ft (recreational pool) per Donner Lake Indenture (see section "Maintenance of Recreational Pools") or if the date is between September 1 and March 31. 
The subblock Power Company operations uses the deficit or excess determined previously to adjust simulated releases computed for the previous time interval. If M\&I demands cannot be met by current streamflow, then releases of stored PCPOSW water must be made from Truckee River Basin reservoirs. The first choice for release is Boca Reservoir PCPOSW if the date is between April 1 and August 31. If PCPOSW releases from Boca cannot be made or are not adequate to satisfy M\&I demands, then PCPOSW from Donner Lake is next for release. The filling of M\&I water supplies in Boca Reservoir from Stampede Reservoir and Independence Lake is described below. If M\&I supplies exceed demand, then reservoir releases are reduced accordingly in the opposite order specified above. The M\&I diversions are then simulated at the appropriate quantity and location.

The USGS Truckee River Basin operations model simulates the maintenance of Boca Reservoir PCPOSW, which facilitates Power Company access to their water. In this subblock the volume of Boca PCPOSW storage is compared to 800 acre- $\mathrm{ft}$. If the current Boca PCPOSW storage is less than 800 acre- $\mathrm{ft}$, then the deficit is determined to be the additional storage of water needed to attain the 800 -acre-ft requirement. The categories and sources used to maintain Boca PCPOSW storage are PCPOSW in Stampede Reservoir and PCPOSW in Independence Lake if Independence Lake storage is greater than 7,500 acre-ft.

The subblock Boca re-regulation uses the demand deficit determined previously to adjust releases simulated for the previous time interval. If Boca Reservoir PCPOSW has a deficit, then releases of stored M\&I water must be made from Little Truckee River Basin reservoirs upstream from Boca. The first choice for release is PCPOSW in Stampede Reservoir. If PCPOSW releases from Stampede are not adequate to achieve Boca PCPOSW storage, then PCPOSW from Independence Lake above the storage of 7,500 acre-ft is the next priority for release.

The following discussion describes how the model simulates reservoir storage according to the Interim Storage Agreement. The model allows the Power Company to store Interim Storage Agreement PCPOSW in Stampede Reservoir only under current operating rules. To store PCPOSW in Stampede according to the interim storage agreement, PCPOSW may be released from Independence Lake and re-stored in Stampede during three periods. First, during the summer period, July 16 to August 17, Independence
Lake waters may be released for the Interim Storage Agreement if (1) lake storage is above a storage of 7,500 acre-ft, (2) lake releases are less than $30 \mathrm{ft}^{3} / \mathrm{s}$, and (3) Stampede levels are below reservoir storage limit of 226,500 acre-ft. Second, during the precautionary drawdown period, August 18 to November 1, lake releases are increased to lower the lake to wintertime cap. For both periods, these releases can be stored in Stampede Reservoir as PCPOSW as long as Stampede storage is below the flood-control criteria storage limit for that period. On September 1, any PCPOSW stored in Stampede greater than 5,000 acre- $\mathrm{ft}$ is exchanged to fish water. Fish credit water is not simulated as a separate water category under current conditions in the operations model.

Truckee-Carson Irrigation District operations using TCIDPOSW from Donner Lake are described in the sections "Truckee River Diversions to Newlands Project," "Reservoir Pass-Throughs and Releases to Meet Newlands Project Demand," and "Merge Reservoir Releases for Multiple Objectives."

\section{Current Operational Exchanges}

Exchanges under current operations are in-lieu-of exchanges. In this type of exchange, water is released from one reservoir in exchange for storage of an equal volume of water in another reservoir. Three common exchanges are currently practiced and simulated by the operations model: the Tahoe-Prosser Exchange, the Donner-Boca Exchange, and the Boca-Stampede Exchange.

\section{Tahoe-Prosser Exchange}

The Tahoe-Prosser Exchange Agreement of 1959 specifies the operation of Lake Tahoe and Prosser Creek Reservoir in order to meet multiple uses (Bureau of Reclamation, 1959). This agreement requires releases from Lake Tahoe to maintain minimum instream flow in the Truckee River downstream from the lake during periods when water would otherwise be stored and accumulated for later release. The required minimum flows downstream from the lake are $50 \mathrm{ft}^{3} / \mathrm{s}$ between October 1 and March 31 and $70 \mathrm{ft}^{3} / \mathrm{s}$ for the remainder of the year. In exchange for the minimumflow releases, an equivalent volume of water must be stored concurrently in Prosser Creek Reservoir in order to compensate for the release from the lake when not required for Floriston rates. Prosser water from the category uncommitted water or Prosser releases of natural 
water are used for the exchange. As pooled water is released from the lake solely to meet minimum instream flows, an equivalent volume of natural water releases or uncommitted water are converted to

Tahoe-Prosser Exchange water (TPEW) in Prosser Creek Reservoir. TPEW stored in Prosser through this exchange can then used to maintain Floriston rates as though it were pooled water stored in Lake Tahoe.

The operations model simulates the TahoeProsser Exchange in the subblock current exchanges. The model code in that subblock uses the minimumflow requirement for the Lake Tahoe outlet of either $50 \mathrm{ft}^{3} / \mathrm{s}$ or $70 \mathrm{ft}^{3} / \mathrm{s}$, assigned in the subblock initial assignments and computations, to simulate the Tahoe-Prosser Exchange. After the assignment of minimum flows downstream from Tahoe, the following computations are determined: (1) the additional release needed to maintain the minimum flows from Tahoe,

(2) the volume of uncommitted water available for exchange in Prosser, (3) the volume of Prosser releases available as natural water, and (4) if Prosser has storage space available. To determine the minimum-flow release from Lake Tahoe, the minimum-flow requirement is compared to the Tahoe release currently simulated. If the Tahoe release exceeds the minimum-flow requirement, no exchange is necessary. However, if the Tahoe release is less than the minimum-flow requirement, the difference is the additional release needed solely to maintain the minimum-flow requirement. This minimum-flow release, limited to the volume of pooled water available in Lake Tahoe and the outlet capacity of the lake, is used for the Tahoe-Prosser Exchange. The volume of uncommitted water available for exchange in Prosser Creek Reservoir is simply the volume of that category in storage.

The proposed minimum-flow release from Lake Tahoe is limited to (1) Prosser Creek Reservoir releases available as natural water and (2) the uncommitted water available for exchange to TPEW in Prosser. The volume of uncommitted water or releases available as natural water for exchange to TPEW in Prosser is equivalent to the additional minimum-flow release needed from Tahoe. No releases solely for minimum flows downstream from Tahoe are made once the supply of uncommitted water or releases are depleted in Prosser.
For simulation of the Tahoe-Prosser Exchange, a tolerance of $0.5 \mathrm{ft}^{3} / \mathrm{s}$ is used to determine when minimum-flow releases from the lake are necessary. If releases from Tahoe are within $0.5 \mathrm{ft}^{3} / \mathrm{s}$ of minimumflow requirements, no additional releases are made.

\section{Donner-Boca Exchange}

The Donner-Boca Exchange is an informal agreement that specifies the operation of Donner Lake and Boca Reservoir in order to meet multiple uses (Richard D. Moser, Sierra Pacific Power Company, oral commun., 1995; Jeff Boyer, U.S. District Court Water Master, oral commun., 1996). This agreement specifies that Donner Power Company privately owned stored water (PCPOSW) required for precautionary drawdown may be released for maintenance of Floriston rates in exchange for reduction of an equivalent volume of pooled water release from Boca and conversion of that retained water to PCPOSW. Thus, depending on the volumes of water exchanged, all or some releases for maintenance of Floriston rates will be made from Donner instead of Boca. In effect, this exchange allows the releases required from Donner to meet three objectives instead of one: (1) fall precautionary drawdown for creation of flood-control space, (2) maintenance of Floriston rates, and (3) PCPOSW from Donner Lake is stored in Boca Reservoir instead of being released and not used downstream.

The operations model simulates the DonnerBoca Exchange in the subblock current exchanges. For an exchange to take place, the model code in that subblock requires that the date is between August 15 and November 15 of any given year, Boca Reservoir is not making required precautionary drawdown releases (see section "Flood-Control Criteria"), Donner Lake is making required precautionary drawdown releases, and Boca is releasing pooled water for maintenance of Floriston rates. To determine the volume of water to be exchanged, the simulated releases of PCPOSW from Donner are compared with pooled water releases, either as adverse- or non-adverse-to-canal water, from Boca. If the pooled water release from Boca is more than the PCPOSW release from Donner, then the exchange volume is limited to the amount of the PCPOSW release. Likewise, if the pooled water release is less than the PCPOSW release, then the exchange volume will be equivalent to the pooled water release from Boca. 
After the exchange volume has been determined for Donner, that volume of PCPOSW is exchanged to natural water and released. For Boca, the exchange of pooled water to PCPOSW is more complex because pooled water consists of adverse- and non-adverse-tocanal waters. Adverse-to-canal water is exchanged to PCPOSW before non-adverse-to-canal water is exchanged. The releases of adverse- and non-adverseto-canal waters from the reservoir are reduced by the same volumes that were exchanged.

The following assumptions were used in the model code to simulate the Donner-Boca Exchange.

- This exchange is not formally specified and described in a legal agreement. Thus, the conditions necessary to initiate this exchange and the categories involved in this exchange may change in response to changing needs of the parties involved.

- The exchange will be simulated if no required precautionary drawdown releases from Boca are currently simulated, even if Boca Reservoir is above the wintertime cap level. An exchange of PCPOSW from Donner Lake to Boca under this condition would provide more storage security for PCPOSW than if this exchange is not simulated and release of PCPOSW from Donner is required for precautionary drawdown.

- The exchange will be simulated only when the precautionary drawdown release of PCPOSW water from Donner Lake is above $5 \mathrm{ft}^{3} / \mathrm{s}$ and the release of pooled water from Boca Reservoir is above $5 \mathrm{ft}^{3} / \mathrm{s}$. These threshold flows may be changed by the user.

\section{Boca-Stampede Exchanges}

It will often be desirable to exchange water stored in Boca Reservoir to Stampede Reservoir. Stampede is the largest reservoir in the Little Truckee River Basin (storage 226,500 acre-ft), and provides greater flexibility in storing water. Water is less likely to be released from this reservoir for flood-control criteria. Water released from Stampede is not generally constrained by outlet hydraulics and may be re-stored in Boca Reservoir. Stampede's large storage capacity and flexibility in operations mean that it will normally possess more secure storage than other reservoirs. Also, because Stampede has a junior storage right to other reservoirs in the Truckee River Basin, it will be the last to fill.
The USGS Truckee River Basin operations model simulates Boca-Stampede Exchange operations in the subblock enhanced storage security. The exchanges from Boca to Stampede are either paper exchanges, in which equal volumes are traded between the two reservoirs with no physical movement of water involved, or re-storage exchanges, in which water is released for storage in a downstream reservoir. There are three likely conditions under which these exchanges are simulated.

1. When the storage of pooled water in Boca Reservoir is less than 5,000 acre-ft, then exchange nonadverse-to-canal water in Stampede Reservoir with fish water in Boca. This condition is simulated when Boca is using pooled waters for Floriston rates and Stampede pooled water is needed in Boca. The following exchanges are possible when Boca pooled water storage is less than 5,000 acre-ft.: (1) paper-exchange fish water in Boca with non-adverse-to-canal water in Stampede Reservoir, and (2) exchange (by re-storage) non-adverse-to-canal water in Stampede to Boca.

2. When any non-adverse-to-canal (pooled) water is remaining in Stampede Reservoir on April 1, then exchange that non-adverse-to-canal water in Stampede to Boca Reservoir. Pooled water may reside in Stampede as a result of previous exchanges, such as those made to facilitate the timely release of fish water for spawning. The fish water in Boca may be spilled and lost during springtime filling of Boca. Thus, it would benefit Pyramid Lake fishes if any fish water in Boca could be exchanged to Stampede. When the date is April 1 and non-adverse-to-canal water is present in Stampede, a paper-exchange of fish water in Boca Reservoir with non-adverse-tocanal water in Stampede is simulated.

3. As discussed in the section "Pyramid Lake Fish," simulated fish water is released from Stampede Reservoir for storage in Boca Reservoir as Boca pressure water. To maintain the Boca pressure water storage, when fish water storage in Boca falls below 2,000 acre-ft during a flow regime 1 from March 1 to June 5, then a paper exchange of fish waters in Stampede is made with nonadverse-to-canal or adverse-to-canal pooled water in Boca. In this exchange for enhanced storage, a paper exchange is simulated between 
Stampede fish water and one of the two categories of pooled water in Boca: (1) paper-exchange non-adverse-to-canal water in Boca with fish water in Stampede, and (2) paper-exchange adverse-to-canal water in Boca with fish water in Stampede.

\section{Merge Reservoir Releases for Multiple Objectives}

Water released from a given reservoir may serve several objectives under current operations. As previously discussed, releases may consist of tagged waters of specific water categories, or may consist of untagged waters of any water category. Typically, releases made to satisfy specific downstream demands are tagged to specific water categories. Such releases in current operations are made to maintain or satisfy Floriston rates, Power Company M\&I demands, Newlands irrigation, and Pyramid Lake fish flows. Untagged releases result from spills (including both uncontrolled spills over reservoir spillways and precautionary drawdowns based on flood-control criteria) or maintenance of minimum flows.

Releases of untagged and tagged waters from a given reservoir form what may be called a "merged reservoir release" because the untagged release may assume the categories of the tagged-water release. Thus, more than one objective may be satisfied. For example, minimum instream flows downstream from Lake Tahoe may be satisfied if releases made for Floriston rates exceed the minimum-flow requirement. If the demand for untagged releases is greater than proposed tagged releases, then water categories must be assigned to that part of the untagged releases that is greater than the proposed tagged releases by a rankorder scheme. The Interim Storage Contract of 1994 (Bureau of Reclamation, 1994) addresses the rank order of water categories for mandatory untagged releases based on flood-control criteria from Stampede and Boca Reservoirs. These categories are used when uncontrolled spills and precautionary drawdowns from these reservoirs exceed tagged releases. The following list provides the order of water categories for release from storage in Stampede during these conditions. Note that project waters (fish water in Stampede and pooled water in Boca) are released last.

1. PCPOSW (Power Company privately owned stored water) in excess of 5,000 acre-ft when total combined storage of PCPOSW in both Stampede and Boca Reservoirs exceeds 5,000 acre-ft.
2. Fish credit water. ${ }^{8}$

3. Remainder of PCPOSW in both Stampede and Boca Reservoirs.

4. Fish water.

For Boca Reservoir, the following list provides the order of water categories for release from storage during these conditions.

1. PCPOSW in excess of 5,000 acre-ft when total combined storage of PCPOSW in both Stampede and Boca Reservoirs exceeds 5,000 acre-ft.

2. Fish credit water.

3. Fish water.

4. Remainder of PCPOSW in both Stampede and Boca Reservoirs.

5. Pooled water.

Untagged releases based on spills for the other Truckee River reservoirs and untagged releases for minimum flows at all reservoirs are not directly addressed in legal agreements and decrees.

The operations model simulates merged reservoir releases for multiple objectives in the subblock merge . First, for each reservoir, the proposed tagged releases are summed and then compared to the mandatory untagged releases representing flood-control releases or releases for downstream minimum flows. The larger of these two types of releases will be used as the newly proposed release. If the tagged release is greater than the mandatory untagged release, then the mandatory untagged release is satisfied by the water categories already proposed for release. Thus, additional untagged releases are not necessary. However, if the mandatory untagged release is greater than the tagged release, then the newly proposed release volume will be equivalent to the volume of the mandatory untagged release. The

\footnotetext{
${ }^{8}$ Fish credit water, under current operations as defined in the Interim Storage Agreement, is established by conversion on September 1 of that part of the combined storage of Power Company privately owned stored water in Stampede and Boca Reservoirs in excess of 5,000 acre-ft. Fish credit water is not simulated as a separate water category under current conditions in the operations model. Fish credit water is used for Pyramid Lake fish species similarly to fish water, but during spill situations, fish credit water will spill before fish water, as listed above. Fish credit water is further defined for draft TROA operations in the subsequent section "Proposed Water Categories."
} 
release is composed of categories used in the tagged releases up to the total volume of that tagged release. The difference between the untagged and tagged releases represents that volume of the mandatory untagged releases that must be assigned to water categories. Table 5 lists tagged and mandatory untagged releases for current operations from each reservoir as simulated in the model.

For each reservoir, if it is determined that untagged releases exceed tagged releases, then that volume of untagged releases that exceeds tagged releases must be assigned to water categories according to a rank order (table 6). Each water category is assigned to the remaining untagged volume on the basis of rank order and the volume of the category available. In table 6 , high rank ( 1 is highest) refers to the simulated release order. If the volume of a water category of higher rank is insufficient to fill the remaining untagged volume, then a water category of a lower rank is used and this process is repeated until the remaining untagged volume is fully tagged with categories. For Prosser Creek and Stampede Reservoirs, the order of water categories changes for different types of releases as shown in table 6 .

The following assumptions were used in the model code development for simulation of the merged releases from reservoirs.

- Except for those water categories specifically assigned in the Interim Storage Agreement (Bureau of Reclamation, 1994) for Stampede and Boca Reservoirs, the rank order of water categories for untagged releases is assumed. These rank orders may be modified by the model user.

- Natural water is assumed to be the inflow category for all reservoirs except Lake Tahoe, where pooled water is the inflow category. Thus, if a reservoir cannot store and must pass through all inflow, the water category passed through is natural water. Natural water can be applied toward Floriston rates, Truckee Canal demand, and Pyramid Lake fish demand.

- For each reservoir, there is only a stepwise determination of water categories for untagged releases as defined by the rank orders shown in table 6. Except for some blending of Power Company and TCID releases from Donner Lake, there is no blending of water categories for untagged releases in the subblock merge.
- Fish credit water is not simulated for current operations. If PCPOSW in the reservoirs exceeds 5,000 acre-ft on September 1, that excess will transfer to fish water instead of fish credit water as stated in the Interim Storage Agreement. The rank order of water categories used for simulations and shown in table 6 does not consider whether the volume of PCPOSW is greater than or less than 5,000 acre-ft.

- All Martis Creek Lake releases are simulated in the subblock flood-control criteria, as this reservoir is operated for flood control. See the previous section, "Flood Control-Criteria," for a description of Martis Creek Lake operations. Storage in and releases from this reservoir consist only of natural water under current operations.

\section{Current River Operations}

In the Nevada part of the Truckee River Basin, water rights are based on the doctrine of prior appropriation, which is often stated as "first in time, first in right." This doctrine states that the first person to put a quantity of water to beneficial use has a higher priority, or right, to the water than a subsequent water user. A water user is assigned a priority date (date of establishment of a water right) that is significant in relation to the dates assigned to other users of the same source of water. The priority date is important when the quantity of available water is insufficient to satisfy entitlements of all active water rights. Under drought conditions, users with later appropriative dates may not receive full entitlement or the amount normally diverted. Almost all of the major diversions from the Truckee River lie in the Nevada part of the basin and are governed by the prior appropriations doctrine. These major diversions include the Truckee Meadows diversions, lower Truckee River diversions, and Truckee River diversions to the Newlands Project.

In the California part of the Truckee River Basin, water rights are based on riparian water rights doctrine. The riparian doctrine states that all persons who own the land adjacent to a stream have an equal right to make reasonable use of the natural streamflow. Riparian users share the streamflow among themselves, and the concept of priority of use is not applicable. Under drought conditions users share shortages. Few major Truckee River diversions in the California part of the basin exist, but those few are operated according to individual decrees, such as the Sierra Valley Decree. 
Table 5. Tagged and untagged releases from reservoirs for current operations

\begin{tabular}{|c|c|c|}
\hline Reservoir & Tagged releases & Untagged releases \\
\hline \multirow[t]{2}{*}{ Lake Tahoe } & Floriston rates: pooled water & Releases due to high lake-level conditions \\
\hline & & Minimum instream flow releases \\
\hline \multirow[t]{3}{*}{ Donner Lake } & Power Company M\&I demand: PCPOSW & Releases due to high lake-level conditions \\
\hline & TCID demand for Newlands irrigation: TCIDPOSW & Minimum instream flow releases \\
\hline & $\begin{array}{l}\text { Pass-through of natural water based on storage } \\
\text { priorities: natural water }\end{array}$ & \\
\hline \multirow[t]{3}{*}{ Prosser Creek Reservoir } & $\begin{array}{l}\text { Floriston rates: pooled water (Tahoe-Prosser } \\
\text { Exchange water) and natural water }\end{array}$ & $\begin{array}{l}\text { Flood-control releases including uncontrolled } \\
\text { spills and precautionary drawdowns }\end{array}$ \\
\hline & Pyramid Lake fish releases: uncommitted water & Minimum instream flow releases \\
\hline & Pass-through of natural water based on storage priorities & \\
\hline \multirow[t]{2}{*}{ Independence Lake } & Power Company M\&I demand: PCPOSW & Releases due to high lake-level conditions \\
\hline & Pass-through of natural water based on storage priorities & Minimum instream flow releases \\
\hline \multirow[t]{3}{*}{ Stampede Reservoir } & Pass-through of natural water based on storage priorities & Flood-control releases including uncontrolled \\
\hline & Pyramid Lake fish releases: fish water & spills and precautionary drawdowns \\
\hline & Power Company M\&I demand: PCPOSW & Minimum instream flow releases \\
\hline \multirow[t]{4}{*}{ Boca Reservoir } & $\begin{array}{l}\text { Floriston rates: pooled water (adverse-to-canal and } \\
\text { non-adverse-to-canal waters) and natural water }\end{array}$ & $\begin{array}{l}\text { Flood-control releases including uncontrolled } \\
\text { spills and precautionary drawdowns }\end{array}$ \\
\hline & Pass-through of natural water based on storage priorities & \\
\hline & Pyramid Lake fish releases: fish water & \\
\hline & Power Company M\&I demand: PCPOSW & \\
\hline Lahontan Reservoir & $\begin{array}{l}\text { Carson Division demand for Newlands irrigation: } \\
\text { pooled water }\end{array}$ & $\begin{array}{l}\text { Flood-control releases including } \\
\text { precautionary drawdowns }\end{array}$ \\
\hline
\end{tabular}

Current river operations can be defined as net diversions from the Truckee River in Nevada and California to satisfy the exercise of agricultural and $M \& I$ water rights. Most diversions made to meet agricultural demands occur during the irrigation season. The irrigation season usually is within the period from April through October of any given year. In practice, the beginning and end of the irrigation season are determined by the amount of recent precipitation, the type of crop grown, or the amount of water available in the river. Current river operations to meet agricultural demands are described in the next four sections. River operations to meet M\&I demands under current operating conditions are described in a previous section, "Privately Owned Stored Water."

\section{Sierra Valley Diversion}

The Sierra Valley Settlement Agreement of 1993 is the basis of operations for diversion of water out of the Little Truckee River to the Feather River Basin in California. The Sierra Valley Ditch diversion is determined using the 1991 Truckee Meadows priority table (Jeff Boyer, U.S. District Court Water Master, written commun., 1994) and the unregulated natural flow at Farad. According to the priority table, Sierra Valley has a priority date of 1870 and has a right to divert water when the unregulated flow is greater than $196 \mathrm{ft}^{3} / \mathrm{s}$ at Farad. The unregulated flow at Farad is computed using an equation, defined in the Sierra Valley Settlement Agreement of 1993, that relates measured flow at Farad, changes in storage in Truckee River reservoirs, Sierra Valley diversions, and evaporation in Truckee River reservoirs. This unregulated flow is computed using a 3-day running average. Also, 
Table 6. Rank order of water categories assigned to untagged releases, by reservoir, under current operations

\begin{tabular}{ll}
\hline \multicolumn{1}{c}{ Reservoir } & Water Categories Assigned to Untagged Release \\
\hline Lake Tahoe & 1. Pooled water. \\
\hline Donner Lake & 1. Natural water. \\
2. PCPOSW and TCIDPOSW. \\
\hline Prosser Creek Reservoir & FOR FLOOD-CONTROL RELEASE: \\
& 1. Natural water. \\
2. Uncommitted water. & 3. Tahoe-Prosser Exchange water. \\
& FOR MINIMUM FLOW RELEASE \\
1. Natural water. & 1. Natural water. \\
2. PCPOSW. \\
\hline Independence Lake & FOR FLOOD-CONTROL RELEASE: \\
1. Natural water. & If controlled spill (precautionary drawdown): \\
& 2. Fish water. \\
3. PCPOSW. \\
If uncontrolled spills: \\
2. PCPOSW. \\
3. Fish water. \\
FOR MINIMUM FLOW RELEASE: \\
1. Natural water. \\
2. Fish water. \\
1. Natural water. \\
2. Fish water. \\
3. PCPOSW. \\
4. Adverse-to-canal water pooled water. \\
5. Non-adverse-to-canal water pooled water. \\
1. Pooled water. \\
\end{tabular}

minimum-flow requirements of the Little Truckee River below the Sierra Valley diversion are considered. These minimum-flow requirements are $5 \mathrm{ft}^{3} / \mathrm{s}$ from March 15 to June $15,3 \mathrm{ft}^{3} / \mathrm{s}$ from June 16 to September 30, and zero the remainder of the year, as stated in the Sierra Valley Settlement Agreement of 1993.

The USGS Truckee River Basin operations model simulates Sierra Valley diversions in the subblock Sierra Valley diversions. The model computes the unregulated flow at Farad using the Sierra Valley Settlement Agreement equation with a 3-day running average of the daily flow. Using the Truckee Meadows priority table, the model simulates Sierra Valley ditch diversions during the irrigation season when the unregulated flow at Truckee River at Farad is greater than $196 \mathrm{ft}^{3} / \mathrm{s}$. Diversions are limited to ditch capacity of $60 \mathrm{ft}^{3} / \mathrm{s}$ and to total flow physically available in the Little Truckee River (reach 185) above the diversion. Additionally, ditch diversions must leave adequate flow in the river to satisfy downstream minimum-flow requirements of $3 \mathrm{ft}^{3} / \mathrm{s}$ or $5 \mathrm{ft}^{3} / \mathrm{s}$. Diversions are stopped when the allowable annual diversion volume of 14,266 acre-ft is reached.

\section{Truckee Meadows Diversions}

Several diversions from the Truckee River are made for agricultural and M\&I use in the Truckee Meadows between the USGS gaging station Truckee River at Farad, Calif., and the USGS gaging station 
Truckee River at Vista, Nev. The Orr Ditch Decree (United States of America v. Orr Ditch Water Company, Equity No. A-3 (D. Nev. 1944)) provides rules and priorities for the allocation of Truckee River water to water-right holders downstream from the Farad gaging station. The Decree established both agricultural and M\&I water rights. Since the court decision, many agricultural rights have been converted to $M \& I$ rights for use by the Power Company. Additionally, the Truckee River Agreement recognizes the Power Company's right to a continuous flow of $40 \mathrm{ft}^{3} / \mathrm{s}$ for M\&I use in the Truckee Meadows. As of 1991, agricultural and M\&I water rights are implemented by the Federal Water Master (FWM) through the use of the Truckee Meadows priority table (Jeff Boyer, U.S. District Court Water Master, written commun., 1994). Water rights are determined according to a fixed schedule of allotments based on priority date. The schedule lists the name of the ditch, water user, priority date, quantity of water available for each right, and estimated transit loss. Transit losses, also called conveyance losses, include seepage, evaporation, and phreatophyte use between the headgates at the river and the point of delivery.

Diversions from the river to a ditch are determined by considering (1) the water-right duties of each ditch as specified in the Orr Ditch Decree, (2) the irrigated acreage served by each ditch, and (3) an efficiency factor, which includes transit losses specified in the Orr Ditch Decree, for each ditch (Jeff Boyer, U.S. District Court Water Master, written commun., 1994). The water-right duty is defined as the volume of water decreed to be applied to each acre of irrigated land, in units of acre-ft per acre. The efficiency factor of a ditch diversion is a fraction (between 0 and 1) computed as the volume of water delivered to water-rights holders at the lateral farm headgates, divided by total diversion from the Truckee River. This measure is estimated, but includes updated information for each ditch diversion regarding transit losses specified by the Orr Ditch Decree (Jeff Boyer, U.S. District Court Water Master, written commun., 1994).

The USGS Truckee River Basin operations model simulates Truckee River diversions in the Truckee Meadows by determining agricultural and M\&I rights in the subblock initial assignments and computations and simulating diversions in the subblock Truckee Meadows diversions.
First, default numerical values are assigned to ditch duties, irrigated acreage, and efficiency for each agricultural and M\&I right in the Truckee Meadows. These values are specified by the Truckee Meadows priority table, as described in the previous section, "Privately Owned Stored Water" (Jeff Boyer, U.S. District Court Water Master, written commun., 1994). All values assigned to duties, irrigated acreage, and efficiency may be modified by the user. Numerical values are not assigned to ditches that are considered permanently abandoned. If the ditch is not currently (1998) used, but is structurally intact for possible irrigation in the future, irrigated acreage is assigned a value of zero, but ditch duties remain as those specified in the Orr Ditch Decree. The maximum cumulative annual diversion, in acre-feet, for each ditch is computed by dividing the duty by the efficiency and then multiplying that result by the irrigated acreage. The irrigated acreage is those lands with decreed rights currently being irrigated. Rights, stated in terms of flow per day, are determined by dividing maximum cumulative annual diversion by the length of the irrigation season. Additionally, ditch diversion accumulators are reset to zero for each ditch at the beginning of the irrigation season, and all ditch diversions are set to zero outside of the irrigation season.

After initial numerical assignments and computations are made, based on the M\&I rights as described above, M\&I diversions are determined as in the previous section, "Privately Owned Stored Water." Based on the agricultural rights as described above, diversions of Truckee River water for agricultural use are determined and simulated in the subblock Truckee Meadows diversions. To simplify the complexity of managing many individual water-right priority dates, several water-right priority dates were grouped together. The conditional logic compares the natural and pooled water flow at Farad to the total amount of agricultural and M\&I rights that could be satisfied. Senior demands will be satisfied before junior demands. If the combined natural and pooled water flow at Farad is less than the total amount of demands, some junior priority-date groups will not be satisfied. Water to meet the agricultural rights allowable under simulated flow conditions is diverted from the mainstem to the appropriate ditch. Once the accumulated daily ditch diversions during an irrigation season has reached the maximum cumulative annual diversion for that ditch, the diversion is set to zero until the next irrigation season. 
In the Truckee Meadows, inflows to the Truckee River can include tributaries, ground-water gains, agricultural diversion returns, and M\&I diversion returns. Time series containing estimates of tributary inflows or channel seepage losses, which could include groundwater gains or losses for the reach between Farad and Vista gaging stations, are described in the section "Data for Simulation of Streamflow and Operations." M\&I and agricultural returns are determined by using observed or estimated values for use and returns in the Truckee Meadows and computing a monthly distribution (expressed as a percentage of annual return) of agricultural and M\&I returns.

Two important assumptions are made in this subblock. First, the default length of the irrigation season is 200 days. This variable may be changed by the user. Second, the beginning date of the irrigation season is determined every spring as either April 1 or April 15, based on the runoff index as described the section "Runoff Index," under the section "Forecasts Affecting Operational Decisions."

\section{Lower Truckee River Diversions}

The USGS gaging station Truckee River at Vista, Nev., designates a boundary between the upstream agricultural and urban lands of the Truckee Meadows and downstream agricultural and undeveloped range lands. Except for a diversion to the Newlands Project via the Truckee Canal that can carry up to about $900 \mathrm{ft}^{3} / \mathrm{s}$ (discussed in the subsequent section "Truckee River Diversions to Newlands Project"), virtually all diversions downstream from the Vista gaging station are to ditches that usually carry less than $40 \mathrm{ft}^{3} / \mathrm{s}$ for irrigation of crops.

The Truckee River Agreement of 1935 and the Orr Ditch Decree of 1944 provide rules and priorities for the allocation of Truckee River water to water-right holders downstream from the Vista gaging station. According to the Truckee River Agreement, 31 percent of all "diverted flow" between the Iceland gaging station and Derby Dam is allocated to the Truckee and Carson Divisions of the Newlands Project and to the Power Company's highest-priority rights for Truckee River water to satisfy M\&I demands. The other 69 percent is allocated to other agricultural and M\&I demands. The Iceland gage is not currently operational and the USGS Farad gaging station (pl. 1) is used as a surrogate. The term diverted flow is considered to be that water used to meet Floriston rates and diverted from the Truckee River to ditches, the Truckee Canal, and municipal water intakes to meet agricultural and M\&I demands, and Truckee River flow downstream from Derby Dam in excess of those irrigation rights downstream from Derby Dam. The "31-percent rule" is rarely practiced in the computation of allowable diversions to the Newlands Project, and therefore is not simulated in the operations model (Jeff Boyer, U.S. District Court Water Master, oral commun., 1996).

The Orr Ditch Decree, in part, adjudicates the appropriative surface-water rights on the Truckee River downstream from the Vista gaging station. These major water rights include diversions to Indian Ditch downstream from the Nixon gaging station (Claim Nos. 1 and 2), and diversions at Derby Dam to the Truckee Canal for the Newlands Project (Claim No. 3, which, in practice, is replaced by Adjusted OCAP). Additionally, for points of diversion downstream from the Vista gaging station, water rights are determined according to a fixed schedule of allotments based on priority date. The schedule lists the name of the water user, name of the ditch, quantity of water available for each right, and estimated transit loss.

As discussed in the previous section "Truckee Meadows Diversions," diversions from the Truckee River for each ditch are determined by considering (1) the water-right duties of each ditch as specified in the Orr Ditch Decree, (2) the irrigated acreage served by each ditch, and (3) an efficiency factor, which includes transit losses specified in the Orr Ditch Decree (U.S. District Court Water Master, written commun., 1995).

Under current operational practices, except for diversions to the Newlands Project, water rights along the Truckee River downstream from the Vista gaging station are usually satisfied, and therefore coordination of diversions with regard to the priority date of each water right is rarely practiced (Jeff Boyer, U.S. District Court Water Master, oral commun., 1996). This is because inflows from TMWRF, Steamboat Creek, and North Truckee Drain upstream from Vista, and groundwater inflows downstream from Derby Dam, usually provide ample water for irrigation demands. However, during dry years when the available flow rate is insufficient to satisfy all irrigation demands concurrently, attempts have been made to regulate diversions on a rotational basis to minimize shortages to individual water rights. Only during extreme shortages will diversions need to be coordinated by a schedule based on water-right priority dates. 
The following discussion describes how the USGS Truckee River Basin operations model simulates Truckee River diversions downstream from the Vista gaging station. The discussion does not include diversions to the Newlands Project via the Truckee Canal, which is described in the subsequent section "Truckee River Diversions to Newlands Project." To simulate diversions from the Truckee River downstream from the Vista gaging station, (1) initial numerical assignments and computations are made, and (2) daily irrigation demands, diversions, and returns are determined. These topics will be further described below.

In the subblock initial assignments and computations, default numerical values are assigned to ditch duties, irrigated acreage, and efficiency for each ditch downstream from the Vista gaging station (U.S. District Court Water Master, written commun., 1995). All values assigned to duties, irrigated acreage, and efficiency may be modified by the user. Numerical values are not assigned to ditches that are considered permanently abandoned. If the ditch is not currently (1998) used, but is structurally intact for possible irrigation in the future, irrigated acreage and efficiency are assigned values of zero, but ditch duties remain as those specified in the Orr Ditch Decree.

From these assignments, the maximum annual diversion volume for each ditch is computed in acrefeet. The maximum annual diversion volume is used to compute the daily diversion right, or demand, for each ditch as described later in the subsection "Daily Diversion Right." For a given ditch, when the accumulated daily ditch diversion during an irrigation season reach the maximum allowable volume for the year, the diversion is "turned off" until the next irrigation season the following year. Other assignments in this subblock include the following items.

- Constant ground-water inflows are assigned to each reach of the Truckee River between Derby Dam and Marble Bluff Dam. The default values of ground-water inflows are based on USGS seepage runs, but may be modified by the user. The seepage runs were serial, nearly concurrent streamflow measurements along the length of the river and some irrigation ditches to determine where flow is gained from or lost to ground water (Berris, 1996).

- Returns from water diverted to irrigation ditches, provide inflows to the river between the Vista gaging station and Marble Bluff Dam. The returns are assigned default values based on FWM estimates, but may be modified by the user (U.S. District Court Water Master, written commun., 1995). These values are fractional factors that are applied to each ditch diversion.

- Ditch diversion accumulators are reset to zero for each ditch at the beginning of the irrigation season. Each accumulator accounts for total diversion volume to date by summing simulated daily ditch diversions.

- All ditch diversions and returns are set to zero outside of the irrigation season.

After initial numerical assignments and computations are made, daily irrigation demands, diversions, and returns are determined in the subblock lower Truckee River diversions. The Truckee River downstream from the Vista gaging station was divided into three segments for simulation of irrigation diversions: segment 1 from the Vista gaging station to Derby Dam (reaches 400 through 450), segment 2 from Derby Dam to Wadsworth, Nev. (reaches 460 through 490), and segment 3 from Wadsworth to Marble Bluff Dam (reaches 500 through 570). Simulation of daily irrigation demands, diversions, and returns involves five computations: (1) daily diversion right, or demand, for each ditch, (2) the "effective" demand for each ditch within a segment, (3) the total effective demand of all diversions within a segment, (4) daily diversions from the river to each ditch, and (5) daily returns to the river from each ditch. The term "effective" demand refers to the net demand from each ditch for water at the upstream end of the given segment, after considering inflows to and outflows from the river within that segment. The total effective demand may be more or less than the summed demands for all ditches in the segment, depending on inflow and outflow locations and volumes. When the total effective demand is greater than the simulated flow at the upstream end of a given segment, it is used to determine a factor for adjusting daily diversion rights of ditches within that segment.

1. Daily Diversion Right-The first computation is to determine the daily diversion right for each ditch. The daily diversion right is simply the maximum annual diversion volume (discussed earlier under initial assignments and computations) divided by the number of irrigation days and con- 
verted to units of flow, cubic feet per second. This flow-rate value represents the average daily diversion demand for each ditch from the river at the location of the given ditch. Once the maximum annual diversion volume has been met, the daily diversion right becomes zero.

2. Effective Demand-The second computation is the effective demand for each ditch. If a daily diversion right exists, it is then adjusted by subtracting inflows from ground water and precipitation, and adding outflows to evaporation and phreatophyte ET from the reach in which the ditch lies. Irrigation return flows from upstream ditches are also considered as inflows to a reach for this computation. This adjusted daily diversion right is called the effective ditch demand and characterizes the specific ditch's demand for water at the upstream end of each segment. For example, if Gregory Ditch, a diversion in reach 470 of segment 2 downstream from Derby Dam, has a daily diversion right of $3.3 \mathrm{ft}^{3} / \mathrm{s}$, but evaporation and phreatophyte $E T$ remove $0.2 \mathrm{ft}^{3} / \mathrm{s}$ from that reach, the effective Gregory Ditch demand will be $3.5 \mathrm{ft}^{3} / \mathrm{s}$ at Derby Dam, the upstream end of segment 2 .

3. Total Effective Demand-The third computation is to determine the total effective demand by totalling the effective demand for all ditches within a segment.

4. Daily Ditch Diversions-The fourth computation is to determine daily ditch diversions from the river to each ditch. The total effective demand is first compared to the simulated flow at the upstream end of the segment. If the total effective demand for a segment is less than the simulated flow, then each ditch within that segment may divert its entire daily diversion right. However, if the total effective demand is greater than the simulated flow, the entire daily diversion right for each ditch in the segment cannot be satisfied and a more complex approach is used to determine the diversions in a given segment. In those cases where water supply is insufficient, an adjustment factor is then determined. The adjustment factor represents the fraction of the total effective demand that can be satisfied by simulated flow at the upstream end of the segment, and is applied to the daily diversion right of each ditch in that seg- ment. Under conditions when full entitlement is not possible, four steps are necessary to determine daily ditch diversions. These four steps adjust the daily diversion right of each ditch by (1) the adjustment factor just described above, (2) inflows from ground-water and precipitation to the reach in which the ditch lies, (3) outflows from the reach to evaporation and phreatophyte ET, and (4) return flows from upstream ditches.

5. Irrigation Return Flows-The fifth computation is to determine return flows of diverted water from each ditch back to the river. Return flows to the Truckee River are simulated by applying the fractional factor described previously and determined in the subblock initial assignments and computations to each daily ditch diversion. Return flows from upstream ditches are also considered as inflows to a reach for the computation of effective demand for each ditch.

An additional objective of the simulation of lower Truckee River diversions is to provide the total effective demand of all diversions in segments 2 and 3 downstream from Derby Dam to Marble Bluff Dam. Water rights of the diversions downstream from Derby Dam are more senior than the Truckee River water rights of the Newlands Project. Thus, allowable simulated diversions to the Newlands Project depend upon the total effective demand needed to satisfy water-right holders on the Truckee River downstream from Derby Dam. Truckee River water can only be diverted to the Truckee Canal after the senior water rights downstream from Derby Dam are satisfied.

Several assumptions were used in the model code to simulate Truckee River diversions downstream from the Vista gaging station.

- The default length of the irrigation season is 200 days and begins on April 1 or April 15, based on NRCS runoff forecasts at Farad (Rebecca Wray, written commun., 1995). The earlier date is used if below-average to average runoff volume is forecasted, and the later date is used if normal or above-average runoff volume is forecasted. The length or begin date may be modified by the model user.

- The model simulates diversions to ditches as continuous or average amounts for each day throughout the irrigation season, so long as Truckee River 
water is available. It is recognized that actual irrigation practices utilize water in a more cyclic manner. For example, in actual practice, fields might only be irrigated once every week or so with a larger daily diversion than the constant diversion simulated by the model. It is assumed that, in practice, the total volume diverted by any given ditch over a period of several days would be the same volume as that produced by the average daily diversion simulated by the model. This also means that given ample supplies of water, the model will divert the full legal amount every year, whether or not the water is needed (in actual operations, recent rains and different crop types may reduce the amount of water required by an irrigator).

- Diversions are not coordinated with regard to the priority date of each water right. Such coordination is rarely practiced because river flows usually provide ample water to meet irrigation demands.

- All ditches in a given segment are coordinated, but each of the three segments is autonomous. Thus, if flow at the upstream end of a given segment cannot satisfy the total effective demand, all ditches in that segment share the deficit. An exception to this assumption is when significant inflows contribute water to reaches toward the downstream end of the segment.

- Estimates of ground-water inflows are only used along the Truckee River downstream from Derby Dam and are based on seepage runs (Berris, 1996).

- The 31-percent rule is not simulated because it is rarely practiced in the computation of allowable diversions to the Newlands Project (Jeff Boyer, U.S. District Court Water Master, oral commun., 1996).

- Returns to the river from ditch diversions are based on simple fractional factors applied to daily ditch diversions. Information on (1) hydraulic characteristics of some irrigation systems, (2) water rights, and (3) historical and present patterns of water use, returns, and spills obtained from the FWM were helpful to estimate returns to the Truckee River (U.S. District Court Water Master, written commun., 1995). The methods of estimating return flows are crude, but are more accurate than if return flows from diversions were ignored. As better information becomes available, the fractional factors may be modified by the user.

\section{Truckee River Diversions to Newlands Project}

Diversion of Truckee River water at Derby Dam to the Newlands Project via the Truckee Canal provides water for irrigation to about 3,500 acres, called the Truckee Division, along the Truckee Canal near Fernley, Nev., and about 56,500 acres, called the Carson Division, downstream from Lahontan Reservoir near Fallon, Nev. (Al Olson, Bureau of Reclamation, oral commun., 1997). The 32.5 mile-long Truckee Canal has a capacity of about $900 \mathrm{ft}^{3} / \mathrm{s}$ and terminates at the reservoir. The interbasin diversion from the Truckee River to Lahontan Reservoir is used to supplement inflow from the Carson River for use by the Carson Division of the Newlands Project. For current river operations, only water from the categories pooled water (which includes natural water inflow to the river upstream from Derby Dam) and TCID water may be diverted to the Newlands Project.

Operating Criteria and Procedures (OCAP) were first introduced in 1967 with the objective to maximize the use of Carson River water for the Newlands Project and minimize the diversion of Truckee River water via the Truckee Canal. A more stringent OCAP was approved in 1973, and in 1988 the OCAP that was used from 1988 to 1997 was approved (Bureau of Reclamation, 1988). A revised OCAP called Adjusted OCAP, was implemented in December, 1997 (Bureau of Reclamation, 1997). Hereafter, OCAP in this report will describe the Adjusted OCAP approved in 1997, unless otherwise indicated.

The OCAP establishes criteria for diversions of pooled water from the Truckee River to the Truckee Canal to provide irrigation water to the Newlands Project. The OCAP are consistent with the fulfillment of the Federal Trust responsibility to the Pyramid Lake Indian Reservation, meeting the requirements of the Endangered Species Act (ESA), and complying with the Orr Ditch Decree of 1944. Thus, waters dedicated to threatened and endangered Pyramid Lake fish and to more senior water rights on the Truckee River downstream from Derby Dam are not diverted to the Truckee Canal. Diversions from the Truckee River to the Truckee Canal are based on end-of-month storage objec- 
tives for Lahontan Reservoir, projected water demands from the Truckee Division, and estimated Truckee Canal losses between Derby Dam and the reservoir.

The Lahontan Reservoir storage objectives are shown in table 3 for the months June through December. For those months, pooled water may be diverted from the Truckee River to Lahontan when the reservoir volume is forecast to be less than the lower storage objective. Diversions are discontinued when the reservoir volume is forecast to equal or exceed the upper storage objective. The end-of-month Lahontan storage objectives for the months January through June are variable, with a goal of achieving a storage of 190,000 acre- $\mathrm{ft}$ at the end of June. The Lahontan storage objectives for those months are influenced by (1) forecasted Carson River flow volume at the USGS gaging station Carson River at Fort Churchill, Nev., from the end of the current month through May or June, (2) Lahontan Reservoir losses from the end of the current month through May or June, and (3) forecasted Carson Division demand for irrigation water from the end of the current month through May or June. Two storage objectives are computed, based on the above items 1 through 3 for May and June. The minimum storage objective is then selected as the final storage objective for the current month.

After the end-of-month Lahontan Reservoir storage objective has been determined, the diversion of Truckee River water to the Truckee Canal can be determined. The diversion to the Truckee Canal is based on (1) the end-of-month storage objective for the reservoir, (2) the Truckee Division demand for the current month, (3) Truckee Canal conveyance losses for the current month, (4) the Carson Division demand for the current month, (5) reservoir seepage and evaporation losses for the current month, (6) reservoir storage at the beginning of the current month, and (7) forecasted Carson River flow volume at the USGS gaging station Carson River at Fort Churchill, Nev., for the current month.

Other aspects of OCAP include (1) calculation of the maximum allowable diversion (MAD) for each year, (2) establishment of efficiency targets, and (3) storage of credit water in Stampede Reservoir. The MAD is calculated annually as the maximum volume of water permitted to be diverted to the Newlands Project to satisfy the exercise of Newlands Project water rights. Efficiency targets and incentives were established as conservation measures to attain and improve project efficiency. Newlands Project effi- ciency is computed as the total amount of water delivered to water-rights holders at the farm headgates, divided by total delivery of water for use in the Truckee and Carson Divisions of the Newlands Project. Low efficiencies mean that conveyance/transit losses, such as seepage, evaporation, or other operational losses prior to delivery of water to headgates, are large. If the actual efficiency exceeds or falls short of the efficiency targets, incentive water credits or disincentive water debits, respectively, are applied to the Lahontan Reservoir storage level for determining Truckee River diversions. The Newlands Project may temporarily store credit water in Stampede in lieu of diversion to Lahontan to avoid spills and exceeding Lahontan storage targets. The credit water retained in Stampede may be released later in that year for diversion to Lahontan or, if not needed to meet Lahontan storage targets, may be retained for later release to Pyramid Lake.

The operations model simulates diversions to the Newlands Project in the subblock $\boldsymbol{O C A P}$. To simulate diversions to the Truckee Canal, the model (1) assigns numerical values to constants and variables, (2) determines Lahontan Reservoir monthly storage objectives, (3) computes Lahontan Reservoir demands from the Truckee River, and (4) determines and simulates proposed Truckee River diversions. The first step, numerical assignments of constants and variables, represents important components for further computations.

Assignments are made to specify values for the following items.

- Carson Division demand-Annual and monthly values that represent demands for irrigation water downstream from Lahontan Reservoir. Default values are provided (Al Olson, Bureau of Reclamation, written commun., 1996) or may be specified by the model user.

- Truckee Division demand-Monthly values that represent demands for irrigation water from the Truckee Canal for lands adjacent to the canal near Fernley, Nev. Two options of default values are provided (Al Olson, Bureau of Reclamation, written commun., 1996). Additionally, values may be specified by the model user.

- Truckee River downstream water rightsMonthly demands for irrigation water from the Truckee River downstream from Derby Dam. These water rights are senior to water rights in the Newlands Project, and thus must be met before 
diversions can be made to the Newlands Project. Demands for irrigation water are computed in the subblock lower Truckee River diversions. These demands are based on water rights specified by the Orr Ditch Decree of 1944 and acreages currently irrigated (Jeff Boyer, U. S. District Court Water Master, written commun., 1995). (See the section "Lower Truckee River Diversions" for a more detailed description of the simulation of demands for irrigation water downstream from Derby Dam.) This is one of two options that describe senior water rights demands downstream from Derby Dam. The second option provides default values of irrigation demands that correspond to Orr Ditch Decree Claim 1 and other irrigation rights downstream from Derby Dam (Stetson Engineers Inc. and G.T. Orlob \& Associates, written commun., 1996). Values of irrigation demands may also be specified by the model user.

- Lahontan Reservoir storage targets-Monthly upper and lower storage targets for the months June through December for the 1988 OCAP. Default values are provided as specified in the 1988 OCAP (table 3) (Bureau of Reclamation, 1988). A second option provides other default values for Lahontan Reservoir storage targets as specified in Adjusted OCAP (table 3) (Bureau of Reclamation, 1997). Values may also be specified by the model user.

- Lahontan Reservoir losses-Monthly reservoir losses that include seepage and evaporation. Default values are provided (Al Olson, Bureau of Reclamation, written commun., 1996).

- Truckee Canal conveyance losses-Daily conveyance losses along the entire canal. Estimated by regression equations provided by the BOR (Alan Olson, Bureau of Reclamation, written commun., 1996).

After numerical values are assigned to the variables described above, Lahontan Reservoir storage objectives are determined on the first day of each month. The following discussion describes the determination of storage objectives for the Adjusted OCAP, but, except for the presence of lower and upper storage objectives and the goal of obtaining higher storage objectives than Adjusted OCAP objectives, the determination is similar for the 1988 OCAP (Bureau of Reclamation, 1997). For the months July through December, storage objectives for Lahontan Reservoir specified in the Adjusted OCAP are used for simulations (table 3). However, for the months January through June, the model code computes the end-ofmonth storage objectives with a goal of achieving a storage of 190,000 acre-ft by the end of June. Within that period, for the months January through April, the storage objective is computed twice; the first computation determines the current monthly storage objective for the period from the end of the current month through May, and the second computation determines the current monthly storage objective for the period from the end of the current month through June. When the simulation date is in May, only one storage objective is computed for the period from the end of May through June. For June simulations, the storage objective is simply 190,000 acre-ft.

The computation of the monthly storage objective for the months January through May requires an estimate of forecasted inflows to and outflows from Lahontan Reservoir. Forecasted Carson River inflows to Lahontan required for the computation are provided by the NRCS in their April through July runoff forecast for the USGS streamflow station Carson River at Fort Churchill, Nev. (Rebecca Wray, Natural Resources Conservation Service, written commun., 1995). Appropriate coefficients are provided to adjust the forecasted inflow to represent the periods form the end of the current month through May or June (Bureau of Reclamation, 1988). Forecasted outflows from Lahontan provided by BOR include forecasted reservoir seepage and evaporation and forecasted Carson Division demands (Alan Olson, Bureau of Reclamation, written commun., 1996). Forecasted reservoir seepage and evaporation represent the period from the end of the current month through May or June. Forecasted Carson Division demands are annual values adjusted by a coefficient provided to represent the period from the end of the current month through May or June. Inflows to Lahontan from the Truckee Canal are not considered in this computation. The final monthly storage objective is the minimum of the May and June computations if the month is between January and April, the June computation if the month is May, and 190,000 acre-ft if the month is June.

After Lahontan Reservoir storage objectives have been determined, Lahontan demands for Truckee River water are computed. The demands for Truckee River 
water are for the remainder of the current month and can be updated about once every five days, but this frequency can be modified by the user. The results of the computations indicate how much water is needed from the Truckee Canal to fulfill Lahontan storage objectives. In addition to requiring the current month storage objective, the computation requires current Lahontan storage and estimates of Carson River inflow, Carson Division demands, and reservoir seepage and losses from the current date to the end of the current month. If the monthly storage objective can be met at the end of the current month without importation of water from the Truckee River, then proposed diversions from the Truckee River for the remainder of the month are assigned to be zero. Otherwise, proposed diversions from the Truckee are computed as the difference between the storage objective and the forecasted reservoir storage at the end of the month without Truckee River inflow.

In addition to providing water to the Carson Division via Lahontan Reservoir, the proposed diversion from the Truckee River must also provide irrigation water to the Truckee Division and provide enough water to compensate for conveyance losses along the Truckee Canal. Therefore, the computation of the proposed diversion requires a forecast of Truckee Division demands for the remainder of the month (Alan Olson, Bureau of Reclamation, written commun., 1996). The proposed diversion is then converted to daily flow and daily Truckee Canal conveyance losses are added. Conveyance losses are simulated using regression equations that are based on flow in the canal and the current month (Alan Olson, Bureau of Reclamation, written commun., 1996). Lastly, after all demands for Truckee River water are totalled, the daily proposed diversion is compared to the $900-\mathrm{ft}^{3} / \mathrm{s}$ capacity of the Truckee Canal and the lesser of the two values is set as the desired diversion amount.

The proposed diversion computed above is a "sustained" diversion because that diversion will attempt to satisfy, using a constant diversion amount, the Lahontan Reservoir storage objective at the end of the current month. An alternative option in the model computes an "opportunistic" diversion that proposes to divert the maximum flow of water available from the Truckee River while still considering the capacity of the Truckee Canal. If the Lahontan storage objective is met before the end of the current month, the diversion to the reservoir is reduced to zero. This second model option still simulates a diversion to the Truckee Canal to provide irrigation water to the Truckee Division.

After the proposed diversion is computed, the diversion may be further limited by the availability of pooled water in the Truckee River and senior Truckee River water rights downstream from Derby Dam. For simulations, only water from the category pooled water may be diverted to the Newlands Project. Therefore, if TCID water is released from Donner Lake, it is converted to pooled water just upstream from Derby Dam for proper simulation of diversions.

An additional computation in the model code in the subblock $\boldsymbol{O C A P}$ is a forecast of Truckee Canal demand from the Truckee River for the periods March through June and April through June. These forecast diversion demands are made on the first day of March and April and are provided to the subblock Pyramid Lake fish operations to determine necessary releases from Truckee River reservoirs for Pyramid Lake fish spawning runs. This computation uses the Lahontan storage target of 190,000 acre-ft for June. The forecast then determines how much additional Truckee River water is necessary to make the June storage target, starting from the current storage. Similar to the forecasts described above, a water balance is determined to compute forecasted Truckee Canal demand from the current date though June. The water balance uses current Lahontan Reservoir storage, inflow from the Carson River to the reservoir, and several outflows from the reservoir and the Truckee Canal. Outflows include the Carson Division demand and seepage and evaporation losses from Lahontan Reservoir, the Truckee Division demand, and Truckee Canal losses from the Truckee Canal (Alan Olson, Bureau of Reclamation, written commun., 1996).

Several assumptions were used in the model code development to simulate diversions to the Newlands Project.

- For simulation of the 1988 OCAP, July through December diversions to the Truckee Canal are based only on the lower storage objective of Lahontan Reservoir. The upper storage objective is not used to decide when diversions are reduced to zero.

- Computations of the forecasted end-of-month Lahontan Reservoir storage are made periodically throughout each month. Estimates of Carson Division demand and the reservoir seepage and 
losses for the remainder of the month are prorated on a daily basis from the monthly values provided. Estimates of Carson River inflows for the remainder of the month are attained by subtracting simulated flow volumes since the beginning of the current month from the monthly forecast provided.

- Operations based on judgement, in contrast to documented rules and policies, are not simulated, nor are aspects of OCAP outside of the geographical scope of the operations model. Therefore, Newlands Project maximum allowable diversion (MAD), efficiency targets, incentives, and disincentives are not considered for the simulation of Truckee River diversions. These aspects of OCAP are dictated by unpredictable human and climatic factors in the Carson Division downstream from Lahontan Reservoir and the Truckee Division adjacent to the Truckee Canal. Also, individual actions taken by the Federal Water Master or BOR to reduce diversions to the Truckee Canal are not simulated. As a result, storage of credit water in Stampede Reservoir based on these types of decisions is not simulated.

- The Truckee Canal capacity is assumed to be $900 \mathrm{ft}^{3} / \mathrm{s}$. It may be modified by the user.

- Truckee Canal conveyance losses are assumed to be uniform along the 32.5-mile length of the canal. Losses for each canal reach were determined by the proportion of the length of that reach to the length of the entire canal.

- Inherent error exists in forecasted values. Therefore, simulated operations based on forecasts may not be as accurate as they would be with perfect foresight.

- A minimum flow of $5.0 \mathrm{ft}^{3} / \mathrm{s}$ is simulated for the terminal reach of the Truckee Canal when Truckee Division demand for Truckee River water is positive but Lahontan Reservoir demand for Truckee River water is zero. This assumption assures that Truckee Division demands are satisfied.

- Truckee Division demands are opportunistically satisfied regardless of Lahontan Reservoir demands for Truckee River water.

- Diversions from the Truckee Canal to satisfy Truckee Division demands are apportioned along the reaches of the canal based on measured flows from 10 diversions along the Truckee Canal for water year 1993. The measured flow from each diversion was compared to the total measured flow from the 10 diversions to determine a proportion coefficient for each diversion. The appropriate coefficient is then applied to the monthly Truckee Division demand to estimate the monthly diversion from each reach.

- Diversions to satisfy animal demands (stockwater) along the Truckee Canal are not simulated. However, an option is available to specify stockwater demands along the canal.

- Categories are converted to pooled water at the downstream end of several reaches for use by Orr Ditch Decree water rights, including the Newlands Project. The following are water category changes for Truckee River reaches.

- For reach 240, just downstream from the Farad gaging station, the category natural water converts to pooled water.

- For reach 360, just downstream from the Glendale Water Treatment Plant, the most downstream Truckee Meadows M\&I water intake on the Truckee River, natural water converts to pooled water and PCPOSW and Power Company $M \& I$ credit water convert to pooled water. Power Company M\&I credit water is a water category only used in draft TROA operations. It is defined for draft TROA operations in the subsequent section "Proposed Water Categories."

- For reach 390, just downstream from Truckee River confluences with Steamboat Creek and North Truckee Drain, natural water converts to pooled water.

- For reach 440, at the USGS gaging station Truckee River below Tracy, Nev., natural water and TCIDPOSW convert to pooled water.

\section{Losses and Gains to Reaches}

Losses and gains due to evaporation, precipitation, and inflows modify the volumes of reservoir and river reaches. Adjustments of reservoir and river storage accounts of water categories from evaporation, precipitation, and inflows are not directly addressed under current operations (Jeff Boyer, U.S. District Court 
Water Master, oral commun., 1998). For reservoirs, evaporation, precipitation, and inflows are not considered separately; rather, "net inflow" is computed as the change in reservoir volume plus measured outflows for each day. When daily net inflow is positive, the inflow of a given reservoir exceeds losses, and conversely, when daily net inflow is negative, losses from evaporation and seepage exceed the daily inflow.

Under current operations, inflow to reservoirs, including tributary inflow and precipitation, is assigned to pooled water for Lake Tahoe and to natural water for the other lakes and reservoirs. However, when evaporation exceeds inflows, net inflow is negative and reservoir storage will decrease. Although not directly addressed in legal decrees and agreements, storage accounts of water categories must be adjusted for the reduction in storage in current operational practices. The accounts of water categories listed below for the seven major reservoirs upstream from the Farad gaging station are considered a reasonable approximation of those used in current practice to reduce reservoir storage.

\section{Lake Tahoe}

Reduction in reservoir storage is allocated entirely to pooled water.

\section{Donner Lake}

Reduction in reservoir storage is allocated first to daily Donner Lake inflow and second equally to Power Company privately owned stored water (PCPOSW) and TCID privately owned stored water (TCIDPOSW).

\section{Martis Creek Lake}

Reduction in reservoir storage is assigned to natural water.

\section{Prosser Creek Reservoir}

Reduction in reservoir storage is allocated first to natural water inflow and uncommitted water in proportion to their volumes, and second to Tahoe-Prosser Exchange water.

\section{Independence Lake}

Reduction in reservoir storage is allocated first to Independence Lake inflow and second to PCPOSW.

\section{Stampede Reservoir}

Reduction in reservoir storage is allocated to all water categories in storage in proportion to their volumes.

\section{Boca Reservoir}

Reduction in reservoir storage is allocated to all water categories in storage in proportion to their volumes.

The following discussion describes how the operations model simulates evaporation, precipitation, and inflow losses and gains from reservoir and river reaches. First, the methods to simulate gains and losses will be described, and then the selection of water-category accounts for gains and losses.

Depending on the external time series input to reservoir and river reaches, either net inflow or separate evaporation and precipitation fluxes may be simulated (see previous section "Data for Simulation of Streamflow and Operations"). Unlike most operations, which are simulated in the SPECL block, tributary inflow, evaporation and precipitation fluxes, or net inflow to and from reservoir and river reaches is simulated in the RCHRES block of HSPF.

For Truckee River reservoirs except Lake Tahoe, Pyramid Lake, and river reaches downstream from Vista, external time series of evaporation and precipitation rates are input to the simulation model. Additionally, inflows are input to the model at reservoir reaches representing upstream model boundaries (Truckee River reservoirs except Lake Tahoe and Pyramid Lake). The inflows were determined by PRMS simulations as described in the previous section, "Data for Simulation of Streamflow and Operations." To simulate evaporation and precipitation volume fluxes to each reservoir and river reach, the time series of rates are applied to the daily simulated surface area of reservoir and river reaches (see previous section, "Description of Hydrological Simulation Program-FORTRAN").

For Lake Tahoe and river reaches upstream from Vista, external time series of net inflows are input to the simulation model. Evaporation and precipitation are included in net inflow, and therefore are not considered separately as described just above. Daily net inflow to Tahoe was calculated by continuity; daily net inflow equals the change in storage plus outflow. External time series of daily net inflows to river reaches upstream from Vista were provided by two methods as described in the previous section, "Data for Simulation of Streamflow and Operations." Upstream from Farad, daily net inflows to river reaches were determined by model simulations using PRMS. Between Farad and Vista, daily net inflows were determined using water 
balance computations or regression analysis. When daily net inflow is positive, the inflow to Tahoe or to the river reaches upstream from Vista exceeds losses, and conversely, when daily net inflow is negative, losses from evaporation exceed the daily inflow. For Lahontan Reservoir, losses are simulated as described in the previous section, "Truckee River Diversions to Newlands Project."

Storage accounts of water categories must be adjusted for changes in storage resulting from losses and gains to reaches. Reservoir inflows for simulation of current operations, including tributary inflow and precipitation, are assigned to pooled water for Lake Tahoe and to natural water for the other lakes and reservoirs. For river reaches, inflow, including tributary inflow and precipitation, is assigned to natural water upstream from the Farad gaging station. Downstream from Farad, all inflows from tributaries and precipitation are assigned to pooled water.

Simulated losses from river reaches from evaporation and ET from phreatophytes are assigned to pooled water downstream from the Vista gaging station (Berris, 1996). Upstream from the Vista gaging station, losses from river reaches are implicit in the described methods used to determine net inflows from tributaries. Because the net inflows to river reaches upstream from Farad are positive, losses are not assigned to water categories upstream from Farad. However, losses may exist between Farad and Vista. These losses are assigned to pooled water.

Simulated reservoir losses, except for Pyramid Lake, from evaporation or negative net inflows are allocated to categories as described in the list above by rank order. If more than one category shares the same rank, then evaporation is assigned to those categories in proportion to the volumes of those categories. For Pyramid Lake, evaporation will be allocated to pooled water.

Assumptions were made in developing the code to simulate losses and gains from evaporation and precipitation and some of the more notable assumptions follow.

- Depending on the external time series data, tributary inflows, evaporation, and precipitation, rather than net inflows, may each be input to the simulation model for all reservoir reaches except Lake Tahoe (see previous section, "Data for Simulation of Streamflow and Operations"). This assumption may create small differences, when loss and gain volumes are assigned to water categories, when compared to the assignment of losses and gains to water categories using just net inflow as input to the simulation model for those reaches.

- Evaporation is only assigned to natural water for Martis Creek Lake simulation.

\section{Description and Simulation of Operations Under Draft Truckee River Operating Agreement and Water Quality Settlement Agreement}

Draft TROA (Bureau of Reclamation and others, 1998), still being negotiated as of 1998 , and the WQSA, signed in 1996, are designed to make more effective and efficient use of water categories in reservoir operations to achieve multiple objectives, including:

1. Increasing the drought water supply for M\&I uses in the Truckee River Basin in California and the Truckee Meadows.

2. Increasing the water supply and improving water management for maintenance of cui-ui flow targets for endangered and threatened Pyramid Lake fish.

3. Enhancing instream flow for fish and water quality.

4. Maintaining reservoir storage levels for recreational uses.

5. Satisfying the exercise of Orr Ditch Decree water rights.

6. Satisfying dam safety and flood-control requirements.

The objectives may be achieved by revising many of the current operations regarding water storage and release practices. Such changes to current operations will add the flexibility to practice different operations that are more effective for different circumstances. However, operations under draft TROA and WQSA are designed to not conflict with Orr Ditch Decree water rights or interfere with flood-control criteria. The fol- 
lowing example illustrates how a proposed reservoir operation, the in-lieu-of exchange, can be used to achieve multiple objectives.

In-lieu-of exchanges involve the release of one or more water categories from one or more reservoirs inlieu of a release of water of yet another category from one or more other reservoirs. This type of exchange is illustrated for Boca Reservoir and Lake Tahoe as follows. Suppose pooled water in Boca is currently being released at a rate of $60 \mathrm{ft}^{3} / \mathrm{s}$ to satisfy Floriston rates. However, an enhanced draft TROA minimum-flow requirement downstream from Lake Tahoe requires a release of $75 \mathrm{ft}^{3} / \mathrm{s}$, or an additional release of $25 \mathrm{ft}^{3} / \mathrm{s}$ greater than the current release of $50 \mathrm{ft}^{3} / \mathrm{s}$ downstream from the lake, which is only enough to meet current minimum-flow requirements. If a proposed credit water category is available to increase the release from Tahoe and if the release from Boca pooled water can be reduced by an equivalent amount, an in-lieu-of exchange may be made to satisfy both the enhanced flow requirement and the Floriston rate requirement.

This example uses fish credit water to increase the release from Lake Tahoe, but one or more other proposed credit water categories in Tahoe may be used for this exchange. Thus, $25 \mathrm{ft}^{3} / \mathrm{s}$ of the $60 \mathrm{ft}^{3} / \mathrm{s}$ pooled water release from Boca Reservoir may be substituted by a release using fish credit water from Tahoe. First, the pooled water release from Boca of $60 \mathrm{ft}^{3} / \mathrm{s}$ is reduced to $35 \mathrm{ft}^{3} / \mathrm{s}$. That volume of pooled water not released from Boca and now held in storage is exchanged to fish credit water. At the same time, an equivalent volume of fish credit water in Tahoe is exchanged to pooled water and then immediately released to be counted toward Floriston rates. Thus, a transaction occurred in which part of a pooled water release from Boca was substituted by a release from Tahoe of pooled water (exchanged from fish credit water). The following four objectives were achieved by this in-lieu-of exchange.

1. Floriston rates were maintained even though the pooled water releases originated from different reservoirs.

2. The enhanced draft TROA minimum-flow requirement was achieved downstream from Lake Tahoe.

3. Boca Reservoir water-surface elevation was sustained for recreational uses.
4. Fish credit water was moved from Lake Tahoe to Boca Reservoir. Fish credit water in Boca can then be exchanged upstream into Stampede Reservoir, which is considered to be the safest reservoir for long-term storage of credit water and more accessible than Lake Tahoe.

Draft TROA and WQSA are separate agreements that can be implemented separately or together. Although the two agreements contain separate objectives, they do contain many common elements. For this report, it will be assumed that when draft TROA is implemented, WQSA will be implemented also. WQSA will utilize procedures and opportunities primarily provided by draft TROA, and will not provide additional procedures. However, WQSA by itself does not provide as many opportunities to achieve waterquality benefits as does draft TROA. Additionally, WQSA by itself does not provide opportunities to achieve benefits other than water-quality benefits, as does draft TROA. Although draft TROA and WQSA will only be discussed together hereafter in this report, the USGS Truckee River operations model provides three options for simulation: (1) current operations, (2) current operations combined with draft TROA and WQSA operations, and (3) current operations, combined with WQSA operations, but without draft TROA operations.

Two key elements of draft TROA and WQSA that enable changes to current operations include (1) reduction of reservoir releases used to maintain flows for Floriston rates and simultaneous retention of that water as credit water in storage, and (2) exchange of water stored in or released from Truckee River reservoirs with water stored in other Truckee River reservoirs. The first element involves reducing the required flow at the Farad gaging station by parties entitled to otherwise divert Truckee River water from Floriston rates releases. The consumptive use portion of such water would be retained as credit storage in reservoirs and would be converted to new credit water categories for accounting purposes. Additionally, this first element involves reducing the required flow at the Farad gaging station when Truckee River flows downstream from Derby Dam, that were released for Floriston rates, are not needed to satisfy Orr Ditch Decree rights or instream flow targets. For this method of credit storage, the entire volume of water not needed to satisfy Orr Ditch Decree rights is retained and converted to a credit water category. Credit storage, as described above, 
does not reduce Floriston rates. Instead, the rates would be a standard from which flow reductions and subsequent water storage can be determined. The newly designated water categories would be available only to satisfy those objectives for which they were retained in storage. These water categories, newly designated for draft TROA and WQSA, will be defined in the subsequent section "Proposed Water Categories."

The second element involves the use of water exchanges between reservoirs to coordinate releases and achieve multiple objectives. Many exchanges are specifically referred to in draft TROA as mandatory exchanges. These exchanges must occur when specified conditions exist. Voluntary exchanges are subject to agreement between affected parties. Many voluntary exchanges are explicitly referred to in draft TROA, but additional voluntary exchanges, not specifically enumerated in the draft TROA, also are allowed if the affected parties agree.

\section{Proposed Water Categories}

A major difference between current and draft TROA operations is the creation, use, and exchange of credit waters under draft TROA. The following credit water categories are identified in draft TROA (with base amounts or storage limits where applicable).

- California M\&I credit water (CMICW) Water stored for M\&I uses in California. Up to 8,000 acre-ft of CMICW could be accumulated with a maximum of 3,000 acre-ft in Truckee River reservoirs other than Lake Tahoe.

- Fernley credit water-Water stored and used by the town of Fernley for M\&I purposes.

- Fish credit water-Water stored and used for the benefit of Pyramid Lake fish. This credit water is established, stored, and managed differently than fish water under current operations. There is no storage limit of fish credit water.

- Joint Program fish credit water (JPFCW) A part of fish credit water stored and used by California for recreational pool and instream flow purposes. The total amount of JPFCW in storage at any time shall not exceed 20,000 acre-ft.

- Newlands Project credit water-Water stored and used to satisfy OCAP demands.
- Other credit water-Water stored and used for beneficial uses that are not defined in draft TROA at this time.

- Power Company emergency drought supply (PCEDS) - Water stored in Stampede Reservoir to provide water under severe drought conditions for Truckee Meadows M\&I purposes. The maximum amount for PCEDS is 7,500 acre$\mathrm{ft}$ as defined in draft TROA.

- Firm Power Company M\&I credit water (firm PCMICW) - Water stored in Stampede Reservoir and used to provide water under drought conditions to Truckee Meadows for M\&I purposes. The base amount for firm PCMICW is defined below in the definition for nonfirm PCMICW.

- Nonfirm Power Company M\&I credit water (nonfirm PCMICW) - Any water other than firm PCMICW and PCPOSW stored in a Truckee River reservoir and used for Truckee Meadows M\&I purposes. The amount of firm and nonfirm PCMICW stored would be based on M\&I demand in Truckee Meadows and California depletions (diverted water not returned to the Truckee River) in the Truckee River Basin in California. The amount of nonfirm PCMICW to be carried over from one year to the next is based on the existence of a drought situation as defined in the section "Forecasts Affecting Operational Decisions." As annual M\&I demand in the Truckee Meadows for Truckee River water increases from 80,000 acre-ft/yr to 119,000 acre-ft, and as California's M\&I depletion of Truckee River basin water increases from 3,000 to 16,000 acre$\mathrm{ft}$ per year, the nondrought-situation carryover limit for storing firm PCMICW would increase from 2,000 to 12,000 acre-ft and the nondroughtsituation carryover limit for nonfirm PCMICW would increase from 4,000 to 20,000 acre- $\mathrm{ft}$ as described by the Preliminary Settlement Agreement (PSA) (California Department of Natural Water Resources, 1991, p.126). During the nondrought situation an adjustment, as a percent determined in the PSA, is made in the computation for the carryover storage of nonfirm PCMICW, whereas during a drought situation, no adjustment is made.

- Water-quality credit water (WQCW) - Water acquired and dedicated to augment instream 
flows in the Truckee River from the Truckee Meadows to Pyramid Lake to enhance water quality and preserve wildlife and fish habitat along the lower Truckee River downstream from Derby Dam, pursuant to the Truckee River Water Quality Agreement. There is no storage limit for WQCW.

\section{Proposed Reservoir Operations}

Under draft TROA and WQSA, several reservoir operations use proposed water categories for storage, exchanges, and demands. These operations are discussed in the following sections.

\section{Storage of Proposed Water Categories}

Under draft TROA and WQSA, credit water categories can be established and accumulated within several Truckee Basin reservoirs. Draft TROA allows flexibility for storage and accumulation of these new water categories; several categories of water may be stored in the same reservoir and each category may be stored in several reservoirs. Currently (1998), there are several "new" categories of credit water still under negotiation. As a result of conceptual uncertainties associated with these "new" water categories and time constraints for documentation of this model, the proposed water categories referred to as Fernley credit water, Newlands Project credit water, and other credit water were not coded and simulated in the USGS Truckee River Basin operations model and, therefore, are not described further in this report.

\section{California Municipal and Industrial Credit Water}

Under draft TROA, California can store a part of its unused surface-water allocation in Truckee River reservoirs for M\&I purposes. California M\&I credit water (CMICW) would be created in Lake Tahoe by exchange of a direct diversion appropriative right of natural water originating downstream from Tahoe in lieu of a release from Tahoe to satisfy that diversion amount. Once in Lake Tahoe, it could be exchanged to other Truckee River reservoirs. Up to 8,000 acre-ft could be accumulated, with a maximum of 3,000 acre$\mathrm{ft}$ in Truckee River reservoirs other than Lake Tahoe. That part of California's surface-water allocation not diverted (either directly for agricultural or M\&I use or accumulated as CMICW storage) can be used to create Joint Program fish credit water (JPFCW), which could be used to maintain instream flows or recreational pool levels in California. Generally, storage, release, and exchange of CMICW storage would have a priority junior only to that of project water.

The following discussion describes how the operations model simulates storage of CMICW. Simulation of CMICW and JPFCW is difficult because, in actual operations, management criteria not yet established will be used in a planning and scheduling process that determines what part of California's surface-water allocation will be used for direct diversion (for M\&I or agricultural use), for storage as CMICW, or for storage as JPFCW. Because the scheduling procedure to be used by California could not be fully characterized in the model code, the simplifying assumptions that follow were developed. In the operations model, California's surface-water allocation is first used to satisfy direct diversion demands for agricultural and M\&I use. That part of the surface-water allocation not used can then be used to satisfy storage needs for CMICW. After direct diversion and storage of CMICW, any of California's unused surface-water allocation will be available to create JPFCW.

The first step in simulating the storage of $\mathrm{CMICW}$ is to assign numerical values to the following variables in the initial numerical assignments and computations subblock.

- Annual volumes are established for California surface-water allocation (10,000 acre-ft) and total allocation (32,000 acre-ft). Total allocation includes both surface- and ground-water allocations.

- Variables are initialized that accumulate annual CMICW storage and JPFCW storage.

- Base demands are set for California M\&I ground and surface water and for surface-water irrigation. The default base level demands are 1992 values obtained from John Sarna (California Division of Water Resources, oral commun., 1997).

- Annual growth-rate factors are set for M\&I surface-water use, M\&I ground-water use, and surface-water irrigation.

- A CMICW storage factor, used to determine the target amount of credit water storage desired in any year, is set by the user. The factor is computed as ratio of the desired amount of credit water in storage divided by the current direct diversion demand for surface water. For example, 
if the direct diversion demand for surface water in a given year is expected to be 5,000 acre- $\mathrm{ft}$, California may elect to keep only three-fourths of that amount in storage as credit water storage for insurance purposes in case of drier-than-expected conditions. So, the CMICW storage factor in this instance would be 0.75 and would be in effect for the entire simulation. In this example, CMICW would only be created if current storage of CMICW was less than the target storage of 3,750 acre-ft $(0.75 \times 5,000=3,750)$, even though up to 8,000 acre-ft of CMICW can be stored under draft TROA rules.

After initial numerical assignments and computations are made, storage of CMICW up to the target amount is simulated in the subblock California $M \& \boldsymbol{I}$ creation. If the demand (base demand adjusted by the growth-rate factor) for direct diversion of surface water in a year is less than California's surface-water allocation (10,000 acre-ft), then the balance is available for storage in Lake Tahoe as CMICW if the following conditions are met.

- Lake Tahoe releases must be greater than minimum or enhanced reservoir release requirements.

- Floriston rates are satisfied.

- Total CMICW currently simulated in storage must be less than 8000 acre-ft.

- Total CMICW currently simulated in storage is less than the target CMICW storage.

- The proposed amount of water to be stored as CMICW must be available as additional pooled water in Lake Tahoe. Also, the hydraulic capacity of the outlet at the lake must be sufficient to allow the release, in addition to what is already being released, of that amount of water proposed for storage as CMICW, just as would be required if California were to exercise its direct diversion right downstream.

If all of these conditions are met, then an amount up to the target amount of CMICW is created by transfer of pooled water in Lake Tahoe to CMICW. The target storage amount is further adjusted by the amount of CMICW already in storage. In other words, a final target storage is computed by subtracting any existing CMICW already in storage from the target storage. Any of California's remaining surface-water allocation not targeted for storage or already planned for direct diversion will then be available for storage as JPFCW. The amount of water available for JPFCW will be the surface-water allocation minus California's planned direct diversion minus the target storage for CMICW. Using the example in the last bullet under initial computations above, if California demand for direct diversion of surface water is 5,000 acre- $\mathrm{ft}$ and the storage factor is 0.75 , then 1,250 acre-ft would be available for the creation of JPFCW that year $(10,000-5,000-$ $3,750=1,250)$, assuming no existing storage of CMICW at the time. See the following section, "Power Company Municipal and Industrial Credit Water, Fish Credit Water, Water-Quality Credit Water, and Joint Program Fish Credit Water," for a discussion of the establishment and storage of JPFCW.

Various assumptions were used in this subblock.

- California M\&I diversions are assumed to be constant for every day of the year from January 1 st through December 31st. Irrigation diversions are assumed to be constant for every day of the irrigation season (length of beginning and ending dates for the irrigation season may vary). As with irrigation water, no more than 25 percent of the surface water available for CMICW can be used in any one month for creation of CMICW.

- The entire surface-water allocation each year is used for direct diversion (for agricultural and M\&I use), CMICW storage, or JPFCW storage. The ground-water use is thus limited to 22,000 acre-ft per year $(32,000-10,000=22,000)$, even though more ground water could be used in practice if the surface-water allocation is not used. The demand for ground water is accounted for in this program because it must be known to determine California depletions and is used, ultimately, in the computation of allowable Power Company M\&I credit water storage (see the section "Proposed Water Categories").

- The operations model does not allow exchanges for storage of up to 3,000 acre-ft of CMICW in other Truckee River reservoirs, even though draft TROA permits such exchanges. Currently, the only fresh-water intake (point of demand) for California M\&I use is at the town of Truckee, Calif. Lake Tahoe is the only storage facility upstream from Truckee that could be operated to meet California M\&I demands. CMICW supplies 
exchanged to other Truckee River reservoirs could not be called upon unless (1) new treatment facilities were constructed downstream from one or more of these reservoirs, or (2) a voluntary exchange of that CMICW into Lake Tahoe was made. For these reasons, the ability to exchange up to 3,000 acre-ft of CMICW from Lake Tahoe to other reservoirs was not included in the operations model.

\section{Power Company Municipal and Industrial Credit Water, Fish Credit Water, Water-Quality Credit Water, and Joint Program Fish Credit Water}

Draft TROA provides procedures for accumulation and storage of Power Company M\&I credit water (PCMICW), fish credit water, water-quality credit water (WQCW), and Joint Program fish credit water (JPFCW) in addition to storage of other water categories. The following discussion will first describe how these credit waters will be accumulated under draft TROA and then describe accumulation as simulated in the operations model.

As previously discussed, PCMICW can be used as M\&I drought supply by the Power Company. It can be accumulated by (1) creating and accumulating the consumptive use portion of former agricultural diversion rights (specified in the Orr Ditch Decree) acquired by the Power Company that would have been released to maintain Floriston rates, (2) re-storage of PCPOSW released from Independence Lake to a designated reservoir, or (3) implementing a number of mandatory and voluntary exchanges and transfers. Only the first method will be described in this section. For that method, PCMICW will be accumulated by a reduction of releases used to maintain Floriston rates corresponding to the daily consumptive use portion of the former agricultural diversion right. The term former agricultural diversion right means a water right from the Truckee River or its tributaries, originally used for irrigation in accordance with the Orr Ditch Decree, that has been purchased or otherwise acquired for uses other than agricultural. The second and third methods of accumulating PCMICW are addressed in the sections "Mandatory Exchanges and Transfers" and "Voluntary Exchanges," respectively.

PCMICW will be classified as either "firm" or "nonfirm." Firm Power Company M\&I credit water (firm PCMICW) can only be stored in Stampede Reservoir. It is a relatively secure water category because it is given a high priority for storage and would be one of the last waters to evaporate or to be released or spilled during flood-control operations. Firm PCMICW also has the first right to credit store in Stampede from July 1 to December 31 of any year if the volume of firm PCMICW in the reservoir is below its base amount and if a nondrought situation is determined (see previous section "Proposed Water Categories" and a later section "Drought Situation" for discussions on firm PCMICW base amounts and nondrought situations, respectively). Nonfirm Power Company M\&I credit water (nonfirm PCMICW) will be less secure than firm PCMICW because it has a lower priority for storage and will evaporate or be released or spilled during flood-control operations before firm PCMICW. Nonfirm PCMICW can be stored in all Truckee River reservoirs. PCMICW created by release reductions can be added to reservoir storage even if that storage means downstream waterquality targets ${ }^{9}$ will not be achieved.

Fish credit water is water other than fish water that can be stored and used directly for the benefit of Pyramid Lake fish. Fish credit water can be accumulated by (1) retaining in storage that portion of pooled water not needed to immediately satisfy Orr Ditch Decree water rights and that would have flowed to Pyramid Lake, and (2) implementing a number of mandatory and voluntary exchanges and transfers. Only the first method will be described further in this section. For that method, pooled water not needed to meet Orr Ditch Decree demands and retained as fish credit water would have flowed to Pyramid Lake as excess to Orr Ditch demands. The second method of accumulating fish credit water, implementing exchanges and transfers, is addressed in the sections of this report, "Mandatory Exchanges and Transfers" and "Voluntary Exchanges." Unlike accumulation of PCMICW corresponding to acquired water rights, there is no limit to the accumulation of fish credit water. The priority for storage of fish credit water is less than that of pooled water, firm PCMICW, and fish water. Therefore, it will be spilled before these other

\footnotetext{
${ }^{9}$ Water-quality targets consist of target instream flows in the Truckee River at Sparks or downstream from Derby Dam (reaches 370 and 450, respectively) to resolve water-quality problems and to improve fish and wildlife habitat. Water-quality targets will be discussed later in the section "Water-Quality Targets and Related Instream Flow Transfers."
} 
categories. Unlike PCMICW, fish credit water cannot be accumulated if such storage results in water-quality targets not being achieved.

The first 7,500 acre-ft of PCMICW transferred to fish credit water in Stampede Reservoir will be reserved as a drought water supply for Truckee Meadows M\&I uses. This water, called Power Company emergency drought supply (PCEDS) in the operations model, can only be used for M\&I purposes after nonfirm and firm PCMICW and Power Company POSW (PCPOSW) supplies have been exhausted and 5,000 acre-ft has been pumped from the dead storage pool of Independence Lake. PCEDS water will have the highest-storage priority and, therefore, will not be subject to spill and will not be subject to evaporation unless it is the last water category in Stampede Reservoir. A more detailed discussion on the creation of PCEDS is presented in a subsequent section, "Other Exchanges and Transfers."

As previously discussed, a part of California's surface-water allocation not scheduled for diversion directly from the Truckee River or stored as California M\&I credit water may be reserved as Joint Program fish credit water (JPFCW) for use in providing minimum instream flows and reservoir recreation pools in Truckee River reservoirs in California. Provided that storage of PCEDS water in Stampede Reservoir is at its 7,500 acre-foot limit, half of the fish credit water accumulated and stored each year will be considered to be JPFCW, up to the annual allocation limit and subject to a 20,000 acre-ft maximum at any time. The priority for storage and spill is that of fish credit water. Once released for instream flows, JPFCW will ultimately flow to Pyramid Lake, but it can be temporarily restored in a downstream reservoir.

As previously discussed in the section "Proposed Water Categories," water-quality credit water (WQCW) is dedicated to augment instream flows in the Truckee River from the Truckee Meadows to Pyramid Lake for the enhancement of water quality and to preserve wildlife and fish habitat along the lower Truckee River downstream from Derby Dam. The WQSA provides for acquisition of Orr Ditch Decree water rights for the creation of WQCW. The accumulation of WQCW will correspond to the consumptive use portion of acquired water rights. Additional accumulation of WQCW of up to 6,700 acre-ft per year will correspond to those Orr Ditch water rights irrigated by sew- age effluent from Truckee Meadows ground-water sources rather than irrigated from pooled water from the Truckee River.

WQCW can be accumulated or created by three methods under draft TROA in conjunction with WQSA. The first method involves reducing releases corresponding to the consumptive use portion of Orr Ditch Decree water rights acquired under WQSA that would otherwise have been released to maintain Floriston rates, and converting the retained pooled water WQCW. The second method involves the accumulation of WQCW during a fish run corresponding to the consumptive use portion of acquired Orr Ditch Decree water rights flowing directly to Pyramid Lake. This water was not released to maintain Floriston rates and, in effect, augments fish water releases during the fish run. As a result, the excess water flowing to Pyramid Lake corresponds to a volume of fish water not released from reservoirs during periods when cui-ui flow targets are in effect (fish runs). It is this stored volume of fish water that may be converted to WQCW in accordance with the daily water rights acquired under WQSA. A discussion on cui-ui flow targets is given in the previous section, "Pyramid Lake Fish." The third method involves the instream creation of WQCW within the Truckee River by transferring to WQCW that part of pooled water obligated to Orr Ditch Decree water rights acquired by WQSA. Instream creation of WQCW is different from the previous two methods in that it involves creation of WQCW as a flow within the river rather than as storage within a reservoir. The instream flow conversions are limited to those times when Truckee River flow is less than the specified water-quality target.

The first and second methods of accumulation of WQCW will be described further in this section. The third method of WQCW accumulation, instream creation of WQCW is addressed in a subsequent section, "Water-Quality Targets and Related Instream Flow Transfers." The priority for storage of WQCW is junior to the priority of all water categories designated under current operations, Power Company M\&I credit waters (PCMICW), fish credit water, California M\&I credit water (CMICW), Joint Program fish credit water (JPFCW), and Power Company emergency drought supply (PCEDS). Accordingly, WQCW will be spilled before these other categories.

The following discussion describes how the model simulates the creation of the draft TROA categories Power Company M\&I credit water 
(PCMICW), fish credit water including Joint Program fish credit water (JPFCW), and water-quality credit water (WQCW). The initial assignments and computations subblock determines the volume of Orr Ditch Decree water rights acquired for PCMICW and WQCW. The credit storage subblock computes accumulations of PCMICW, WQCW, and fish credit water and JPFCW by reduction of releases for Floriston rates. WQCW also may be accumulated by a second method in the credit storage subblock, in which fish and fish credit waters retained during fish runs are exchanged to WQCW. A third method for creation of WQCW involves the instream conversion of pooled water to WQCW in the Truckee River and is described in the section "Water-Quality Targets and Related Instream Flow Transfers." The primary objective of instream creation of WQCW is similar to the objective of releasing WQCW: to satisfy water-quality targets at Sparks and downstream from Derby Dam. Therefore, the instream creation of WQCW is simulated with reservoir releases of water-quality water in the subblock water-quality credit water operations. Lastly, credit waters accumulated by exchanges between reservoirs or by re-storage is typically an auxiliary benefit from many operations that are discussed in numerous sections regarding draft TROA operations. Such operations that serve other objectives in addition to their primary objective can be called "multi-purpose" operations and illustrate the flexibility available under draft TROA. Consequently, these multi-purpose operations are discussed elsewhere in this report. Additionally, creation of firm and nonfirm PCMICW and creation of Power Company emergency drought supply (PCEDS) will be described in a subsequent section, "Other Exchanges and Transfers."

The initial assignments and computations subblock provides default values of former irrigated acreages to determine water rights acquired for PCMICW and WQCW waters. The default values may be modified by the user. Acquired water rights are determined by applying consumptive use duties, rather than irrigation ditch duties, to the former irrigated acreages. Consumptive use duties, referring to water actually consumed for irrigation that does not return to the river, are assumed to be 2.5 acre-ft per acre. These duties are less than irrigation ditch duties because ditch efficiencies and return flows are not considered.

Additional water rights for creation of WQCW, up to 6,700 acre-ft per year, are obtained from irrigation of Orr Ditch water rights using sewage effluent originating from Truckee Meadows ground water sources rather than pooled water from the Truckee River. Thus, irrigators use sewage effluent instead of pooled water. As a result, that pooled water may be retained in storage for conversion to WQCW. The volume of sewage effluent used for irrigation is set by the user in the subblock initial assignments and computations. This volume is then added to the acquired water rights for creation of WQCW.

From the above assignments and computations, the annual water rights acquired for PCMICW and WQCW are used to compute the daily water rights for each purpose. Because the Power Company may directly divert acquired agricultural water rights from the Truckee River for M\&I uses, the daily water right for credit storage is limited to the consumptive use portion of acquired rights not diverted (a discussion of Power Company M\&I demands for Truckee River water was given in the previous section "Privately Owned Stored Water"). The daily water rights constitute the maximum daily volume of PCMICW and WQCW that may be created. The creation of each water category during a given month may not exceed 25 percent of its annual water right allocation. It is assumed that former agricultural diversion rights can only be used to create draft TROA water categories during the irrigation season because these rights are based on agricultural uses during this period.

Creation of fish credit and Joint Program fish credit waters (JPFCW) are not based on model code in the initial assignments and computations subblock. Instead, creation of fish credit water, from which JPFCW and Power Company emergency drought supply (PCEDS) waters are created, is based on retaining pooled water releases for the maintenance of Floriston rates if that release is not needed to satisfy Orr Ditch Decree rights and, as a result, flows to Pyramid Lake. Therefore, a determination is made in the subblock credit storage whether or not pooled water releases for Floriston rates can be retained for creation and storage of these waters.

After initial assignments and computations are made, the subblock credit storage simulates the creation and storage of credit water by (1) reducing the portion of releases for Floriston rates not required to satisfy the exercise of water rights and converting the retained water to Power Company M\&I credit, fish credit, or water-quality credit waters, or (2) converting retained fish and fish credit waters to WQCW during fish runs. Reduction of releases to maintain Floriston 
rates are made in accordance with (1) excess Power Company water rights not diverted for M\&I uses that could convert to PCMICW and water rights acquired for WQCW, (2) the flow of pooled water to Pyramid Lake for fish-credit water, and (3) the allowable reduction of releases of pooled water for Floriston rates. Note that reservoir pass-throughs of natural water for Floriston rates and Truckee Canal diversion rights, as discussed in the sections "Floriston Rates" and "Reservoir Pass-Throughs to meet Newlands Project Demands," may also be reduced and the natural water retained will be used for creation and storage of PCMICW, fish credit water, and WQCW. Hereafter, to simplify the text, reduction of these reservoir passthroughs will be implicitly included within the discussion of reduction of Floriston rates releases for creation and storage of credit waters.

Priorities and constraints further influence the manner in which the credit waters are created and accumulated. PCMICW and fish credit water have equal priority for creation and storage, whereas WQCW has a lesser priority. However, the Power Company will have the first right to store firm PCMICW in Stampede Reservoir from July 1 through the following December 31 of any year if the volume of firm PCMICW in Stampede is below the base amount and if it is determined that a drought situation does not exist. (See the subsequent section "Forecasts Affecting Operational Decisions" for a description of a drought situation.) Note that for simulations, nonfirm PCMICW will be first established under the conditions described above. Firm PCMICW will then be established from nonfirm PCMICW up to the base amount by simulating a transfer as described in the subsequent section "Other Exchanges and Transfers." Fish credit water and WQCW may not be added to storage by reduction of releases if that storage results in water-quality targets not being met in the Truckee River at Sparks or downstream from Derby Dam (reaches 370 and 450, respectively).

The following is an overview of the conditional logic upon which storage of PCMICW, fish credit water, WQCW, and JPFCW by reduction of releases for Floriston rates is based.

1. Determine credit storage rights. Credit storage rights are the volume of credit waters that can be accumulated in appropriate reservoirs based on appropriate adjustments to former diversion rights or to unused pooled water flowing to
Pyramid Lake (reach 580).

Adjust former diversion rights acquired for PCMICW as determined in the subblock initial assignments and computations. Daily credit storage rights for PCMICW are based on acquired rights (estimated consumptive use portion of diversion right) not currently needed for Truckee Meadows water demand as determined in the subblock Power Company operations. Credit storage rights are reduced to zero if accumulated creation for the year exceeds the acquired water rights or if releases of PCPOSW or PCMICW are made to satisfy Truckee Meadows water demand.

Determine credit storage rights of fish credit water based on pooled water downstream from Derby Dam (reach 450) that flows to Pyramid Lake and storage of fish credit and Joint Program fish credit water from the previous time step. Credit storage rights for fish credit water are reduced to zero during fish runs.

Adjustments to daily credit storage rights for WQCW are limited by the accumulated amount each year. If accumulated WQCW equals or exceeds the acquired rights, storage rights are reduced to zero. Further, credit storage rights are reduced to zero when attainment of water-quality targets along the Truckee River depends on releases or instream creation of WQCW or if water-quality targets cannot be attained.

2. Determine maximum reduction of releases for Floriston rates for each reservoir. The maximum reduction is based on the difference between the currently calculated release value and the required minimum release for each appropriate reservoir. Required minimum releases, or "release floors," are of two types: overall and category. "Overall release floors" are based on releases that do not require specific category releases, such as releases for minimum-flow targets or releases for required spills or precautionary drawdowns. "Category release floors" are based on specific categories that are involved in higher-priority operations and exchanges than those currently considered, such as the TahoeProsser Exchange, as discussed in the section "Tahoe-Prosser Exchange" under "Current 
Operational Exchanges.”

The allowable reduction in release is determined for the following reservoirs and water categories.

- Lake Tahoe-pooled water.

- Donner Lake-not applicable (no credit waters are created in this reservoir by the operations model).

- Martis Creek Lake-not applicable (current version of operations model does not simulate creation of credit waters in this reservoir, although draft TROA specifies creation of fish credit water during flood-control operations).

- Prosser Creek Reservoir-Tahoe-Prosser Exchange water and natural water.

- Independence Lake-not applicable (no credit waters created in this reservoir by the operations model).

- Stampede Reservoir-natural water.

- Boca Reservoir-adverse-to-canal, nonadverse-to-canal, and natural waters.

3. Determine preliminary volume of credit water that can be created by reduced reservoir releases. Total credit storage rights (PCMICW storage rights plus fish credit water storage rights plus WQCW storage rights from item 1 above) are compared with total allowable reduction of reservoir releases (item 2) from all appropriate reservoirs listed above. The minimum value is considered as a preliminary measure of the total volume of credit water that can be created in all appropriate reservoirs.

4. Determine maximum amount of credit waters that can be created while accounting for water-quality flow targets at Sparks and downstream from Derby Dam. The flow targets are currently set to $300 \mathrm{ft}^{3} / \mathrm{s}$ and $135 \mathrm{ft}^{3} / \mathrm{s}$, respectively, during June-September and $50 \mathrm{ft}^{3} / \mathrm{s}$ at both sites for the remainder of the year. This computation involves computing the difference between simulated flow at Sparks and below Derby Dam at the beginning of the time step and the value of the respective water-quality targets. This computation ensures that the creation of fish credit water and WQCW will not reduce simulated flows below waterquality targets.

5. Determine the volumes for PCMICW, WQCW, and fish credit water that can be created and stored using the maximum amount of credit water that can be created (item 4). This determination imposes a complex set of constraints and limitations for the credit waters, including priorities for creation, storage, and adherence to water-quality targets. As previously discussed, PCMICW and fish credit water typically have equal priority of creation and storage, whereas WQCW has a lesser priority. However, firm PCIMICW may have the highest priority for credit storage in Stampede Reservoir between July 1 and December 1 if the storage of firm PCIMICW is below its base amount and if there is no drought situation. Additionally, creation of fish credit water and WQCW must not result in the failure to achieve water-quality targets. Creation of PCMICW, however, is not limited by this constraint.

For simulations, the creation and storage of each type of credit water is based on a comparison of the overall maximum volume available for credit water creation (item 4) and the total daily credit storage right determined for each type of credit water (item 1). The outcomes of the comparisons determine the volume of each type of credit water that can be created for all appropriate reservoirs. The reservoir for which each credit water is created is determined after this step. The outcomes of the comparisons are outlined in detail below.

- If the maximum volume available for credit water creation equals or exceeds the total storage right of all credit waters considered, then the creation of each type of credit water will correspond to the daily credit storage right for that type of water determined in item 1 above.

- If the maximum volume available for credit water creation is less than the total storage right of all credit waters considered, then two outcomes are possible.

If the maximum volume available for credit water creation is less than the total storage right of PCMICW, fish credit water, and 
WQCW, but exceeds the storage right of PCMICW plus fish credit water, then creation of PCMICW and fish credit waters will correspond to the daily credit storage rights for those waters as determined in item 1 above. Because of its lesser priority for creation and storage, creation of WQCW will be restricted to the difference between maximum volume available for credit water creation and the storage right of PCMICW plus fish credit water just determined.

If the maximum volume available for credit water creation is less than the storage right of PCMICW plus fish credit water, then WQCW cannot be created because of its lower priority for creation. Because PCMICW and fish credit waters have an equal priority for creation, the model computes a proportional coefficient relating maximum volume available for credit water creation to the storage right of PCMICW plus fish credit water. The proportional coefficient is applied only to the daily credit storage right for fish credit water. The coefficient is not used for the creation of PCMICW because the creation of this water category is not restricted by the attainment and maintenance of water-quality targets. Therefore, PCMICW is computed simply as the difference between the total volume of credit water creation unrestricted by water-quality targets (item 3 above) and the volume of fish credit water to be created.

6. Determine the total reduction in releases for Floriston rates corresponding to the volume of credit waters to be created and accumulated in reservoirs. The total reduction of releases for Floriston rates is simply the summation of the volumes of credit water creation determined in item 5 and corresponds to the maximum volume of credit water that can be created while accounting for water-quality flow targets described in item 4. The subblock credit storage uses the total reduction in releases for Floriston rates to appropriately adjust reservoir releases to retain pooled and natural waters for transfer to credit waters.

The adjustment of releases from each reservoir and the volume of retained pooled and natural water to be converted to PCMICW, fish credit water, and WQCW in each reservoir is outlined in item 7.

7. Prioritize the reservoirs and stored water categories used for credit water creation and storage. The following list describes the order of reservoirs for the simulation of reducing releases for Floriston rates and converting the category of the retained water to credit waters. The list is based on the rank-order list of reducing releases when Floriston rates are exceeded, as described in the section "Floriston Rates."

- Lake Tahoe pooled water if the date is between April 1 and October 31 and if the water surface elevation is greater than $6,225.5 \mathrm{ft}$.

- Prosser Creek Reservoir Tahoe-Prosser Exchange water if the date is between April 1 and September 3 and if storage is less than 19,000 acre-ft (desired recreation volume threshold).

- Boca Reservoir non-adverse-to-canal water.

- Boca Reservoir adverse-to-canal water.

- Prosser Creek Reservoir Tahoe-Prosser Exchange water if the date is between April 1 and September 3 and if storage is greater than 19,000 acre-ft or if the date is between September 4 and March 31.

- Lake Tahoe pooled water if the date is between April 1 and October 31 and if the water surface is between 6,223.0 ft (outlet rim) and 6,225.5 ft or if the date is between November 1 and March 31.

- Stampede Reservoir natural water.

- Boca Reservoir natural water.

- Prosser Creek Reservoir natural water.

8. Determine the reduction of releases for each appropriate reservoir. For each reservoir listed above in item 7 , the total reduction in releases for Floriston rates determined in item 6 is compared to the maximum reduction in releases for that reservoir (item 2). The minimum value of the comparison is then used to reduce the release for each reservoir. 
9. Determine the volume of retained water to be transferred to each type of credit water at each reservoir. The total reduction in releases for Floriston rates (item 6) represents the volume of releases to be reduced and subsequently credit stored. It will be used to govern credit water creation in each reservoir.

If the maximum reduction in release for Floriston rates at a given reservoir (determined in item 2) equals or exceeds the total reduction in releases for Floriston rates for all appropriate reservoirs (item 6), then the volume of retained water used for transfer to each type of credit water corresponds to the volume that can be created and accumulated of that type of credit water for all appropriate reservoirs, as described in item 5.

If the maximum reduction in release for Floriston rates at a given reservoir is less than the total reduction in releases for Floriston rates for all appropriate reservoirs, then the volume of retained water transferred to each type of credit water is proportionally reduced from the volume of each type of credit water that can be created and accumulated for all appropriate reservoirs.

10. Transfer retained water to appropriate credit water categories as determined in item 9.

11. Decrement the total reduction in releases for Floriston rates corresponding to the volume of credit waters to be created and accumulated in reservoirs (item 6) according to the volume of retained water to be transferred to credit waters (item 8).

Decrement the volume of each type of credit water that is available for creation (item 5) according to the volume of retained water transferred to each type of credit water (item 9).

12. Determine the creation of Joint Program fish credit water (JPFCW), which is based on the unused portion of California's surface-water allocation each year (see discussion in the section "California Municipal and Industrial Credit Water.") If California does not use the direct diversion rights of its surface-water allocation or credit store the unused portion of that direct diversion right, then the unused annual allocation amount is available for creation of JPFCW.
JPFCW is created concurrently with fish credit water. Half of the created fish credit water is transferred to JPFCW.

Creation of Power Company emergency drought supply (PCEDS) is discussed in the section "Other Exchanges and Transfers," and is simulated in the subblock TROA mandatory exchanges.

13. Accumulate credit waters as they are created and stored each calendar year. The PCMICW and WQCW accumulated each year will be compared with credit storage rights on the following day (item 1).

In addition to the creation of credit waters by reduction of releases for Floriston rates, WQCW may be created during periods when cui-ui flow targets are in effect (fish runs) (see section "Pyramid Lake Fish"). This is accomplished by converting retained fish and fish credit waters already in storage to WQCW in exchange for unused pooled water flowing to Pyramid Lake during a fish run. The unused pooled water flowing past upstream diversions to Pyramid Lake used for this exchange results from reduced consumptive use associated with former agricultural water rights acquired in accordance with the provisions of WQSA. This unused pooled water augments, in effect, fish water and fish credit water releases during a fish run.

The following list is an overview of the conditional logic upon which the storage of WQCW by retention of fish and fish credit waters during a fish run is based.

1. Determine credit storage rights of WQCW. Adjust former diversion rights acquired for WQCW as determined in the subblock initial assignments and computations. Daily credit storage rights exist if (1) WQCW volume established for the current year is less than the consumptive use portion of former agricultural rights acquired, (2) the simulation period is within a fish run of fish regime 1 (see section "Pyramid Lake Fish"), and (3) unused pooled water corresponding to the consumptive use portion of daily water rights acquired by WQSA is flowing to Pyramid Lake (reach 580). If any of these conditions is not true, WQCW will not be accumulated. Note that during fish runs, the daily water rights acquired by WQSA will flow past diversions, including the 
Truckee Canal, to Pyramid Lake. Additional adjustments limit the accumulation of WQCW.

- WQCW will not be accumulated when attainment of water-quality targets along the Truckee River depends on current releases or instream creation of WQCW.

- WQCW accumulation will be limited to the consumptive use portion of acquired water rights flowing to Pyramid Lake.

- WQCW accumulation will be further limited to the cui-ui flow targets determined for fish regime 1.

2. Prioritize the reservoirs and stored water categories used for creation of WQCW during a fish run. The following list is the order in which reservoirs and water categories are evaluated for storage of WQCW and is loosely based on the priority list of reservoir releases for fish runs (see section "Pyramid Lake Fish").

- Stampede Reservoir-fish credit water.

- Prosser Creek Reservoir-fish credit water.

- Boca Reservoir-fish credit water.

- Lake Tahoe-fish credit water.

- Stampede Reservoir-fish water.

- Prosser Creek Reservoir-uncommitted water.

- Boca Reservoir-fish water.

3. Determine the volume of WQCW to be created in each reservoir that potentially can release fish and fish credit water for cui-ui flow targets. However, a given reservoir cannot credit store if it is releasing for flood control as mandated by flood-control criteria (see previous section, "Flood-Control Criteria").

If the reservoir is allowed to credit store, the volume of credit storage is computed on the basis of the daily credit storage right (item 1 above) and the volume of water from appropriate water categories that could potentially be released for the fish run. The potential release of that water category is limited by the volume available in storage and the hydraulic constraints of the outlet.
4. Transfer that volume of retained fish or fish credit water to WQCW in accordance with item 3.

5. Decrement the daily credit storage right, determined in item 1, by the volume of fish and fish credit water transferred to WQCW.

6. Add the newly created credit water to the annual accumulated WQCW. The annual accumulated WQCW will be compared with credit storage rights on the following day (item 1).

Several assumptions were made in developing the code to simulate the creation, accumulation, and storage of all kinds of credit waters. Some of the more notable assumptions follow.

- Credit waters can only be created during the irrigation season if their creation is based on former diversion rights specified in the Orr Ditch Decree. This assumption is specific to PCMICW and WQCW. The volume of these waters created in any given month within the irrigation season may not exceed 25 percent of their annual water right.

- PCMICW accumulation is simulated as nonfirm PCMICW from which firm PCMICW will later be created by transfer in accordance to the base amount required for firm PCMICW (see subsequent section, "Other Exchanges and Transfers").

- Simulations of credit water creation and storage do not attempt to combine reductions of releases from more than one reservoir concurrently to optimize other objectives. However, elsewhere in the model code, water categories and releases are exchanged between reservoirs to satisfy other objectives.

- Credit water creation and storage are not simulated for Martis Creek, Donner, and Independence Lakes.

- The priority order of reservoirs for reducing releases for Floriston rates and subsequent creation of credit waters is based on priorities for reducing releases when Floriston rates are exceeded. The priority list may be rearranged by the model user.

- The priority order of reservoirs for creation and storage of WQCW during fish runs is assumed and is loosely based on the priority list of reser- 
voir releases for fish runs. The priority list may be rearranged by the model user.

- Reservoir releases of fish or fish credit water during a fish run are not required for creation of WQCW during a fish run. The only requirement is to demonstrate that reservoirs would have had to release fish or fish credit water if pooled water did not augment flow to Pyramid Lake.

\section{Reservoir Releases to Meet Downstream Demands}

Under draft TROA, reservoir releases and diversions to satisfy demands may differ from those specified under current operations. These differences may be as simple as updated specifications for release procedures to maintain Floriston rates. However, most of the changes will be more extensive. First, additional proposed demands (California M\&I, water-quality targets, and local M\&I water use from Lake Tahoe and Donner and Independence Lakes) will need to be simulated under draft TROA conditions. Second, in addition to the current categories used to satisfy current demands, TROA will provide categories that could be used to meet both current demands (for example, PCMICW for Power Company Operations demands and fish credit water for Pyramid Lake fish demands) and new demands under draft TROA (for example, CMICW for California M\&I demands and WQCW for water quality demands). Also, reservoir releases to satisfy these demands, along with storage or exchange of credit waters, can be managed to achieve multiple objectives under draft TROA. These demands are described further in the sections that follow.

In addition to describing proposed release procedures for maintenance of Floriston rates, four types of credit waters used in these releases are discussed in this section: (1) Power Company M\&I credit water, (2) fish credit water, (3) California M\&I credit water, and (4) water-quality credit water. A separate reservoir demand specified in the draft TROA is diversion of water from Lake Tahoe, and Donner and Independence Lakes for M\&I use in California. Operations to satisfy demands for JPFCW are described in the sections dealing with mandatory and voluntary exchanges.

\section{Floriston Rates}

Release procedures for maintaining Floriston rates will be modified for Tahoe-Prosser Exchange water (TPEW) under draft TROA. TPEW will continue to be released to maintain Floriston rates, but in accor- dance with new rules linked to volumes and water-surface elevations of Prosser Creek Reservoir, Boca Reservoir, and Lake Tahoe. TPEW released to maintain Floriston rates will not produce flows at Farad, exclusive of all categories except natural water and pooled water (including TPEW), in excess of Floriston rates unless additional releases of TPEW from Prosser Creek Reservoir are necessary to assure that active storage does not exceed the flood-control criteria of 8,640 acre-ft on November 1. Additionally under draft TROA, TPEW will be released for Floriston rates according to the following criteria.

1. TPEW will be released from Prosser Creek Reservoir to assure that its storage in that reservoir shall not be greater than 7,500 acre- $\mathrm{ft}$ if (a) Boca Reservoir storage will be less than 32,900 acre-ft, and if (b) Lake Tahoe water-surface elevation will be lower than 6,227.5 feet on November 1 .

2. All TPEW in Prosser Creek Reservoir will be released before the date Boca Reservoir storage is scheduled to be less than 20,000 acre-ft.

3. TPEW will be released from Prosser Creek Reservoir in accordance with flood-control criteria to assure that the volume of TPEW in storage will be no greater than 8,640 acre- $\mathrm{ft}$ of active storage on November 1.

The USGS Truckee River Basin operations model simulates the maintenance of Floriston rates using a rank-order procedure based on rules described previously for current operations (see section "Floriston Rates" under "Current Reservoir Operations") and additional criteria specified in draft TROA and described above. As previously discussed, the status of flow at the Farad gaging station (reach 240) is defined in reference to Floriston rates in the subblock initial assignments and computations. The water categories natural water flow and pooled water flow (including releases of TPEW from Prosser Creek Reservoir) are added and that sum is compared with target Floriston rates as defined in table 2 . The subblock maintenance of Floriston rates uses the computed deficit or excess to determine reservoir releases and pass-throughs of natural water for maintenance of Floriston rates.

The following list describes the order of water categories and sources used to maintain Floriston rates. If a deficit is determined, additional reservoir releases or pass-throughs of natural water will be simulated in 
the order described below. If Floriston rates are exceeded, then releases and pass-throughs of inflow are reduced in the opposite order. Most of these sources also are used for the simulation of current operations and were described previously. Those sources under draft TROA that differ from current operations are marked with an asterisk (*).

1. Natural water inflows from unregulated tributary subbasins (sidewater) and pass-through of natural water inflow to reservoirs that is not stored or evaporated.

2. Pass-through of natural water inflow from Prosser Creek Reservoir.

3. Pass-through of natural water inflow from Stampede Reservoir.

4. Pass-through of natural water inflow from Boca Reservoir.

5. Release of pooled water from Lake Tahoe if, in addition to maintaining Floriston rates, additional releases are also needed to maintain minimumflow targets just downstream from the lake (see previous section, "Minimum Instream Flows," for a description of minimum-flow targets under current operations).

*6. Release of TPEW from Prosser Creek Reservoir if:

a. The date is between June 1 and November 1, Boca Reservoir storage volume is less than 32,900 acre-ft, Lake Tahoe water-surface elevation is less than $6,227.5 \mathrm{ft}$, and storage of TPEW in Prosser Creek Reservoir is greater than 7,500 acre-ft. If the date is between June 1 and September 3 (part of the recreation season), TPEW is released from Prosser Creek Reservoir only if that reservoir's water volume is greater than or equal to 19,000 acre-ft (recreation volume threshold). After September 3, this constraint is not simulated. June 1 is used as the start date for this release because it is assumed that there will be ample time between June 1 and November 1 to release TPEW to assure that its storage in Prosser Creek Reservoir will be no greater than 7,500 acre-ft by November 1 if the other criteria apply. b. At any time the Boca Reservoir storage is less than 20,000 acre-ft.

c. The date is between September 4 and November 1 and TPEW in storage in Prosser Creek Reservoir is greater than 8,640 acre-ft.

7. Release of pooled water from Lake Tahoe if:

a. The date is between April 1 and October 31 and if the water surface elevation is between 6,223.0 (outlet rim) and 6,225.5 ft.

b. The date is between November 1 and March 31.

8. Release of Tahoe-Prosser Exchange water from Prosser Creek Reservoir if:

a. The date is between April 1 and September 3 (recreation season) and if total reservoir water volume is greater than or equal to 19,000 acre-ft (recreation volume threshold), or

b. The date is between September 4 and March 31.

9. Release of adverse-to-canal water from Boca Reservoir.

10. Release of non-adverse-to-canal water from Boca Reservoir.

11. Release of Tahoe-Prosser Exchange water from Prosser Creek Reservoir if the date is between April 1 and September 3 and if total reservoir water volume is less than 19,000 acre-ft.

12. Release of pooled water from Lake Tahoe if the date is between April 1 and October 31 and if the water surface elevation is greater than $6,225.5 \mathrm{ft}$.

The following assumptions are used in the model code development for simulation of maintenance of Floriston rates under draft TROA, in addition to those assumptions listed in the discussion of Floriston rates in the section "Current Reservoir Operations."

- Reservoir releases and pass-throughs are not "scheduled" in advance for smoothing of reservoir releases over weekly/monthly periods. Methods to schedule reservoir operations in the Truckee River Basin are undocumented. Releases and pass-throughs for maintenance of Floriston 
rates are determined on a daily basis contingent upon the criteria specified above.

- TPEW is stored only in Prosser Creek Reservoir for simulations. In actual operations under draft TROA, it may occasionally be exchanged to another reservoir.

\section{Power Company Municipal and Industrial Credit Water}

Under draft TROA, the Power Company will have the right to store and release PCMICW in all Truckee River Basin reservoirs. This will provide additional waters to satisfy Power Company M\&I demands and increase the M\&I drought supply. Draft TROA does not state that Boca pondage will be available for storage of PCPOSW.

The USGS Truckee River Basin operations model simulates proposed operations of Power Company M\&I credit water as follows. PCMICW categories may be used in addition to the current water categories for releases to satisfy M\&I demands. As previously described under current operations, the model simulates Power Company operations M\&I demands and the location of M\&I diversions. Logic in the Power Company operations subblock is then used to determine (1) PCPOSW supplies available from reservoir storage or other Orr Ditch Decree rights, and (2) M\&I diversion demands. The simulation of releases to meet M\&I demands under draft TROA using PCMICW is similar to the simulation of PCPOSW releases as discussed in the section "Privately Owned Stored Water." The logic for the draft TROA and current operations is the same except that the allowable $M \& I$ reservoir releases of firm and nonfirm PCMICW for draft TROA are based on (1) drought situation, as defined in the section "Drought Situations," and (2) PCPOSW stored in Donner and Independence Lakes. The re-regulation of Power Company water within Boca Reservoir is discussed later in this section.

The following sources are used to satisfy Power Company M\&I demands under draft TROA. Most are also used in current operations and were described in the section "Privately Owned Stored Water." Those sources under draft TROA that differ from current sources are marked with an asterisk (*). Current sources previously presented are listed here again for reader convenience.
1. First $40 \mathrm{ft}^{3} / \mathrm{s}$ of Truckee River and first $13.6 \mathrm{ft}^{3} / \mathrm{s}$ of Hunter Creek streamflow per Truckee River Agreement.

2. Available Orr Ditch Decree (United States of America v. Orr Ditch Water Company, Equity No. A-3 (D. Nev. 1944)) agricultural rights converted to M\&I rights flowing in the Truckee River.

3. Release of PCPOSW from Boca Reservoir.

4. Release of PCPOSW from Donner Lake if the date is between April 1 and August 31 and if the water surface elevation is above $5,932.0 \mathrm{ft}$ recreational pool per Donner Lake Indenture (see section "Maintenance of Recreational Pools").

5. Release of PCPOSW from Donner Lake if the date is between September 1 and March 31.

*6. During a drought situation (defined later in the section "Drought Situations," under the section "Forecasts Affecting Operational Decisions"), the following reservoir releases are used in the order shown below:

a. Nonfirm PCMICW in Lake Tahoe.

b. Nonfirm PCMICW in Prosser Creek Reservoir.

c. Nonfirm PCMICW in Boca Reservoir.

The following list shows the order of the sources used in the model to re-regulate Power Company waters by storing them in Boca Reservoir under draft TROA operations. Some of these sources also are used in simulation of current operations and were described in the section "Privately Owned Stored Water." Those sources under draft TROA that differ from current sources are marked with an asterisk (*). Regardless of whether or not a drought situation exists, sources 1 and 2 are available.

1. PCPOSW in Stampede Reservoir.

2. PCPOSW in Independence Lake if lake storage is above 7,500 acre-ft.

*3. PCPOSW in Independence Lake if lake storage is above 7,500 acre-ft if under drought situation as defined in the section "Drought Situation."

*4. Nonfirm PCMICW in Stampede Reservoir if under drought situation. 
*5. Firm PCMICW in Stampede Reservoir if under drought situation.

*6. Remainder of PCPOSW in Independence Lake above outlet $(6,921.0 \mathrm{ft})$ if under drought situation.

*7. 7,500 acre-ft of PCEDS credit water in Stampede Reservoir if under drought situation.

Several assumptions were used in the model code development for simulation of releases of PCMICW that are different from current operations.

- Under draft TROA, the order of water categories allows for the pumping of 5,000 acre-ft of water in Independence Lake below the outlet elevation of 6,921.0 ft prior to using the 7,500 acre-ft of PCEDS water in Stampede Reservoir. This scenario is not simulated by the operations model due to model limitations.

- As described in procedures in draft TROA, and subject to compliance with the National Environmental Policy Act, the California Environmental Quality Act, and administrative/regulatory review, the order of water categories used by the Power Company allows for the pumping of Lake Tahoe below the natural rim after using the 7,500 acre-ft of PCEDS in Stampede Reservoir. This scenario, also, is not simulated by the operations model due to model limitations.

\section{Fish Credit Water}

In addition to releases of fish water and uncommitted water, some of the demands for Pyramid Lake fish will be met by the release of fish credit waters under draft TROA operations.

The USGS Truckee River Basin operations model simulates release of fish credit water in the subblock Pyramid Lake fish operations as follows. Fish credit water may be used in addition to current water categories for releases to satisfy fish demands and for storage to satisfy Boca pressure water storage. As previously described under current conditions, determination of releases needed to satisfy the needs of Pyramid Lake fish requires the model to compute the amount of water available for fish operations, the flow regime, and cui-ui flow targets. Additionally, the model determines the need for Boca Reservoir storage of fish water or fish credit water according to Boca pressure water.
The logic for draft TROA and current operations to satisfy Pyramid Lake fish demands is the same except for the release of fish credit water. The list below shows the sources of reservoir releases used in the model under draft TROA. Most of these sources also are used in current operations and were described in the section "Pyramid Lake Fish." Those sources under draft TROA that differ from current sources are marked with an asterisk (*). Current sources are listed again here for reader convenience. The term prescribed threshold volume refers to reservoir volumes specified to constrain selected reservoir operations for the purposes of maintaining the security of water categories. The term preferred flow targets is described in the section "Preferred Instream Flows."

*1. Fish credit water in Lake Tahoe, if storage is above the Lake Tahoe prescribed threshold volume. Use Tahoe releases up to preferred flow target.

*2. Fish credit water in Boca Reservoir, if storage is above the Boca Reservoir prescribed threshold volume.

*3. Fish credit water in Prosser Creek Reservoir, if storage is above the Prosser Creek Reservoir prescribed threshold volume. Use Prosser Creek Reservoir releases up to preferred flow target.

*4. Remaining fish credit water in Lake Tahoe.

*5. Remaining fish credit water in Boca Reservoir.

*6. Remaining fish credit water in Prosser Creek Reservoir.

7. Fish water in Boca Reservoir (from Stampede Reservoir).

8. Uncommitted water in Prosser Creek Reservoir.

The following two sources of Stampede Reservoir releases are used in the model to satisfy Boca pressure storage in draft TROA simulations. Source 2 also is used for current operations and described in the section "Pyramid Lake Fish." The source marked with an asterisk (*) is different from current sources.

*1. Fish credit water in Stampede Reservoir.

2. Fish water in Stampede Reservoir. 


\section{California Municipal and Industrial Credit Water}

Currently, there are no operations implemented to satisfy California M\&I demands. Under draft TROA operations, CMICW will be used to meet California M\&I demands. Current California M\&I demands are not published, but are expected to increase as population growth continues in the Truckee, Calif. area. Most of California M\&I credit water will be diverted at Truckee. As specified in draft TROA, for California to make direct diversions, flow at Truckee River at Farad must be greater than the rights senior to the CMICW. These rights are the sum of claims 1 and 2 of the Orr Ditch Decree (United States of America v. Orr Ditch Water Company, Equity No. A-3 (D. Nev. 1944)) plus $40 \mathrm{ft}^{3} / \mathrm{s}$. The Truckee River Agreement of 1935 specifies that the Power Company shall have the right to the first 40 $\mathrm{ft}^{3} / \mathrm{s}$ of pooled water in the Truckee River at Farad.

The USGS Truckee River Basin operations model simulates releases of California M\&I credit water as follows. To simulate releases for California M\&I operations from the Truckee River, (1) initial numerical assignments and computations are made, and (2) releases to meet California M\&I demands are determined.

California M\&I demands are specified on the subblock initial assignments and computations. These demands require the user to specify:

- Growth rates for California M\&I surface-water and ground-water use,

- Growth rate for California agriculture surface water,

- Consumptive use factors for water used to satisfy California agricultural and M\&I demands,

- Decimal fraction of current annual California surface-water M\&I usage that will be held in storage,

- California annual surface-water allocation and total allocation, and

- Base-year levels for California M\&I surfacewater and ground-water diversions and agricultural surface-water use.

Other assignments in this subblock include the following.

- A tolerance of $0.1 \mathrm{ft}^{3} / \mathrm{s}$ is assigned to determine when CMICW releases are necessary. If releases for CMICW are within $0.1 \mathrm{ft}^{3} / \mathrm{s}$ of the demand, no additional releases are made. This tolerance may be modified by the user.

- The total flow of rights senior to the CMICW is calculated as the sum of Indian Ditch diversion plus the Power Company right of $40 \mathrm{ft}^{3} / \mathrm{s}$.

After initial numerical assignments and computations are made, releases to meet California M\&I demands are determined in the subblock California M\&I demands. First, the natural water flow at Truckee, Calif. (reach 150) is determined. Second, the status of river flow at this site is compared to the California M\&I demands. If the river flow is less than the demand, then the deficit is determined as that additional flow of water needed to achieve the California M\&I demands. Likewise, if the river flow is more than the demand, the excess is determined. M\&I credit water, if available, is released from Lake Tahoe if a demand is not achieved. No action is taken if streamflow is in excess of California M\&I demand.

Several assumptions were used in this subblock.

- No CMICW is stored in reservoirs other than Lake Tahoe because the M\&I intakes are located at Truckee, Calif. as described in the section "California M\&I Credit Water" under "Storage of Proposed Water Categories."

- Daily surface-water diversions equal the sum of agricultural and M\&I diversions during irrigation season. Outside of the irrigation season, when irrigation demands are zero, the daily diversion equals the M\&I diversion.

- Because the exact value for current California M\&I demands are not published, the default M\&I demand used in the model should be considered an estimate.

- Claims 1 and 2 of the Orr Ditch Decree are assumed in the model to be the simulated diversion for Indian Ditch as described in the section "Lower Truckee River Diversions," based on current operation practices. This simulated diversion is based on 1991 converted water rights defined in a FWM table "Truckee Meadows Priorities" (Jeff Boyer, U.S. District Court Water Master, written commun., 1994). Also, Indian Ditch diversions are only simulated during the irrigation season. Claims 1 and 2, as defined in the Orr Ditch Decree, are more than this simulated diversion. 


\section{Diversion of Water in Lake Tahoe and Donner and Independence Lakes for Municipal and Industrial Use in California}

This section addresses operations that divert waters directly from Lake Tahoe and Independence and Donner Lakes. These diversions differ from those diversions described in the sections "Truckee Meadows Diversions," "Privately Owned Stored Water," "Power Company M\&I Credit Water," and "California M\&I Credit Water." Under draft TROA, the combined maximum interstate allocations for the Lake Tahoe Basin total 34,000 acre-ft, of which 11,000 acre-ft is for Nevada users and 23,000 acre-ft is for use in California. This allocation can be derived from ground-water or surface-water sources. The allocation is principally for M\&I use, but also can be used for snowmaking. For Donner Lake, the maximum annual allotment specified in the draft TROA for M\&I water use is 990 acre- $\mathrm{ft}$, and for Independence Lake it is 50 acre- $\mathrm{ft}$. General guidelines for monthly M\&I diversions from Donner and Independence Lakes were obtained (Richard D. Moser, Sierra Pacific Power Company, oral commun., 1997). For 1994, annual diversions from Lake Tahoe for California were about 16,900 acre-ft (John Sarna, California Department of Natural Resources, written commun., 1998) and for Nevada were about 10,000 acre-ft (Thomas R. Scott, Bureau of Reclamation, oral commun., 1998).

The following discussion describes how the operations model simulates diversions from Lake Tahoe and Donner and Independence Lakes for M\&I use. First, both the maximum and annual M\&I use in acrefeet is specified for all three lakes in the initial numerical assignments and computations subblock. For Lake Tahoe and Donner and Independence Lakes, the maximum annual allotment specified for M\&I water use is 26,900 acre-ft (John Sarna, California Department of Natural Resources, written commun., 1998), 990 acre-ft, and 50 acre-ft, respectively, and the current annual usage is $26,900,495$, and 0 acre-ft, respectively. The volumes may be changed by the user. After these initial assignments, diversions are determined in the code in the subblock California M\&I demands using the following logic.

- Lake Tahoe and Donner Lake-Because residents use water from Lake Tahoe and Donner Lake year-round, it was assumed that M\&I uses takes place from January 1 to December 31 . Observed values for M\&I use in the Truckee
Meadows (Richard D. Moser, Sierra Pacific Power Company, oral commun. 1995), were used to determine a monthly distribution (expressed as a percentage of annual use). This monthly percentage distribution was multiplied times the annual allotment to compute, a constant daily M\&I diversion for each month for Lake Tahoe and Donner Lake.

- Independence Lake-The model default is that no water be simulated for diversion from Independence Lake. If changed by the user, M\&I diversions from the lake will take place during the summer, between June 1 and August 30. The annual M\&I use would be simulated by dividing the specified annual allotment over the 3-month period.

- The operation model is designed to divert pooled water from Lake Tahoe and natural water from Donner and Independence Lakes for M\&I water use in California.

\section{Water-Quality Targets and Related Instream Flow Transfers}

Releases and instream flow transfers can be made in accordance with the WQSA to achieve target instream flows in the Truckee River from Reno to Pyramid Lake. The objective of these water-quality targets is to provide streamflows adequate to resolve some of the water quality problems in the Truckee River in Nevada and, simultaneously, to improve fish and wildlife habitat along the Truckee River.

Water-quality flow targets have been specified for Truckee River at Sparks and Truckee River below Derby Dam. The flow targets are currently set to $300 \mathrm{ft}^{3} / \mathrm{s}$ and $135 \mathrm{ft}^{3} / \mathrm{s}$, respectively, during June-September, and $50 \mathrm{ft}^{3} / \mathrm{s}$ at both sites for the remainder of the year (Chester Buchanan, U.S. Fish and Wildlife Service, oral commun, 1999). Releases to augment other water categories in the river to meet the waterquality targets are made using WQCW created as described in the previous section "Storage of Proposed Water Categories." It is anticipated that most WQCW will be created in Lake Tahoe and Stampede, Boca, and Prosser Creek Reservoirs. Releases of WQCW from these reservoirs will be used to satisfy flow targets at Sparks and below Derby Dam. It is anticipated that Boca will be used for temporary storage of WQCW for quick release to the mainstem Truckee River, similar to 
current operations for Boca pressure water conditions. The schedule and amount of WQCW that would be temporarily stored in Boca are not currently specified.

The USGS Truckee River Basin operations model simulates releases for water-quality targets as follows. All WQCW releases and flow transfers may be turned off or on at the option of the user. Simulation of releases to meet water-quality target requires that (1) initial numerical assignments and computations are made, (2) reservoir releases to meet water-quality targets are determined, and (3) Stampede Reservoir WQCW releases to Boca Reservoir be determined.

First, water-quality flow targets at Sparks (reach 380) and below Derby Dam (reach 460) are specified each month in the initial assignments and computations subblock. These targets may be changed by the user. Water rights in the Orr Ditch Decree, including the Truckee Division of the Newlands Project, that have been acquired for uses specified in WQSA are specified in this subblock. These acquired water rights may be modified by the user. Additionally, a tolerance of $0.1 \mathrm{ft}^{3} / \mathrm{s}$ is assigned to determine when WQCW releases are necessary. If releases of WQCW bring the total streamflow at Sparks and below Derby Dam to within $0.1 \mathrm{ft}^{3} / \mathrm{s}$ of targets, no additional releases are made. This tolerance may be modified by the user.

After initial numerical assignments are made, reservoir releases to meet water-quality targets are determined in the subblock water-quality credit water operations. The first step is to determine the total river flow simulated at Sparks and below Derby Dam. The streamflow at these sites is compared to the specified water-quality flow targets. If the river flows are less than a target, the deficit is determined as that additional flow of water needed to achieve water-quality targets. Likewise, if the simulated river flows at these locations are more than the targets, an excess is determined, upon which reductions in releases of WQCW are based.

The following reservoir sources of WQCW are used in the model to achieve water-quality targets.

1. Lake Tahoe, if the volume is greater than the lake's prescribed threshold volume.

2. Prosser Creek Reservoir, if the volume is greater than the reservoir's prescribed threshold volume.

3. Boca Reservoir, if the volume is greater than the reservoir's prescribed threshold volume.

4. Prosser Creek Reservoir, if the volume is greater than the reservoir's recreational level. The recre- ational level is described in the section "Maintenance of Recreational Pools."

5. Remainder of WQCW from Lake Tahoe.

6. Remainder of WQCW from Prosser Creek Reservoir.

7. Remainder of WQCW from Boca Reservoir.

The subblock water-quality credit water operations uses the deficit and excess values determined previously to appropriately adjust releases every third day. If the water-quality targets cannot be met by existing surface-water supplies and by reservoir releases from the previous time interval, then additional releases of stored WQCW must be made from Truckee River Basin reservoirs in the order specified above. Likewise, if existing water-quality targets are exceeded, then reservoir releases are reduced accordingly in the opposite order specified above.

Next, the model determines Stampede Reservoir WQCW releases to Boca Reservoir. The objective of these releases is to provide ample supply of WQCW to Boca Reservoir for releases directly to the Truckee River to satisfy water-quality targets. The storage of WQCW in Boca is compared to the total volume of WQCW reservoir releases for that day. If the WQCW storage in Boca is less than the total volume of WQCW reservoir releases, then WQCW from Stampede is delivered to Boca to meet WQCW releases from Boca for the next day.

The following assumptions were used in this subblock.

- Storage of WQCW is not simulated for Donner and Independence Lakes.

- Water-quality targets may be met by flows provided for other uses. For example, if water to meet Floriston rates demand satisfies water-quality targets, then no additional release of WQCW from reservoirs is necessary.

- The locations and magnitudes of water-quality targets have changed since the signing of WQSA and are subject to revision based on further negotiations with interested parties.

Similar to the release of WQCW from reservoir storage to achieve and maintain water-quality targets in the Truckee River, WQCW may be created as instream flow to also achieve and maintain water-quality targets. 
This method involves the instream flow transfer of that part of pooled water obligated to Orr Ditch Decree rights acquired by WQSA to WQCW. Instream flow transfers are limited to those times when Truckee River flows are less than specified water-quality targets. Instream creation of WQCW is a river operation that involves creation of that category as flow within the river, rather than as storage within a reservoir.

The following discussion describes the simulation of instream flow transfers to create WQCW. Similar to the creation of credit water as storage in reservoirs, the initial assignments and computations subblock determines the volume of Orr Ditch Decree rights acquired for the conversion to $\mathrm{WQCW}$ as either flow or storage. The quantity of WQCW created by instream flow transfers is then simulated in the subblock water-quality credit water operations.

As described in the section "Power Company M\&I Credit Water, Fish Credit Water, Water-Quality Credit Water, and Joint Program Fish Credit Water," the Orr Ditch Decree water rights acquired for the creation of WQCW are determined in the subblock initial assignments and computations. Similar to the creation of WQCW water in storage, the instream transfer of pooled water to WQCW as flow is limited to the consumptive use portion of former agricultural water rights or effluent volume originating from Truckee Meadows ground water and reused for irrigation. However, unlike creation of WQCW as reservoir storage, creation of WQCW as flow is strictly for the immediate maintenance of downstream water-quality targets rather than for future satisfaction of that demand.

Instream transfers of pooled water to WQCW may be simulated concurrently with reservoir releases of WQCW in the subblock water-quality credit water operations. The instream exchanges are simulated between reach 250 and reach 260, just downstream from the Farad gaging station and just upstream from Truckee Meadows M\&I and agricultural diversions and the California-Nevada State boundary. Additionally, creation of WQCW by instream transfers is restricted to the period between June and September, when streamflow is more likely to be less than waterquality targets. After September, if water-quality targets cannot be maintained, WQCW will be released from reservoirs if it is available. The following overview describes the conditional logic that simulates creation of instream WQCW.
1. Determine the volume available for WQCW creation which is based on acquired rights determined in the initial assignments and computations subblock. If the accumulated creation of WQCW, as storage and flow, equals or exceeds the acquired rights, additional credit water cannot be created. Additionally, if Floriston rates cannot be maintained, then the volume of acquired water rights available for credit water creation is reduced on the basis of the pooled water flow available for transfer.

2. Determine the volume of the instream flow transfer from pooled water to WQCW. As for the release of WQCW described previously, a deficit or excess is determined, depending on a comparison of the river flow at Sparks and below Derby Dam and the established water-quality targets. The volume of the transfer is determined by adjusting the transfer from the previous time step corresponding to the deficit or excess. Thus, for a deficit, more water will be transferred to WQCW and for an excess, less water will be transferred in accordance to the volume of acquired rights and the pooled water in reach 250 available for exchange.

3. Transfer pooled water flow to WQCW flow.

4. Accumulate the WQCW as it is created each calendar year. The cumulative total also includes water-quality water created in reservoir storage. The annual accumulated WQCW will be compared with acquired water rights on the following day to determine if more credit water may be created.

Two assumptions were made in developing the code to simulate the instream creation of water-quality water.

- WQCW is created by instream flow transfers prior to being released from reservoirs. It is assumed that stored water-quality water can be saved to achieve water-quality flow targets later in the year.

- WQCW is created just downstream from the Farad gage because the acquired water rights are Orr Ditch Decree rights, and therefore are associated with Floriston rates. 


\section{Mandatory Exchanges and Transfers}

Under draft TROA, mandatory exchanges are used for moving water categories (physically or administratively) among reservoirs. Transfers, as defined for this report, are used to create storage of one category by eliminating an equal volume of another category in the same reservoir. Mandatory exchanges and transfers simulated in the Truckee River Basin operations model are used to (1) achieve enhanced minimum instream flows as described below in the section "Enhanced Minimum Instream Flows," and (2) favor the storage of selected new credit water categories depending on specific conditions, such as current reservoir storage and the presence of drought situations as described in a later section, "Other Exchanges and Transfers."

\section{Enhanced Minimum Instream Flows}

Currently, several reservoirs in the Truckee River Basin are operated to provide releases necessary to maintain instream flows just downstream from reservoirs. However, draft TROA provides for greater minimum instream flows than previously described in current operations. The greater flows, termed enhanced minimum instream flows, would be achieved using draft TROA credit water categories, PCPOSW, uncommitted water, and fish water. Additional releases of these water categories requires that they be either re-stored in another reservoir or exchanged with water categories in other reservoirs (in-lieu-of exchanges). Additionally, the use of such waters for enhanced minimum instream flows may depend on the security of the new storage location, the current availability and location of reservoir storage before re-storage or exchange, type of season (normal season or dry season), and the current status of streamflow with respect to enhanced flow targets at given locations. California, at its discretion, could use JPFCW to enhance minimum instream flows without re-storage or exchange with water in another reservoir.

Releases of all water categories except JPFCW to enhance instream flows require that the storage level in those Truckee River reservoirs selected for release, restorage, or exchange be within prescribed constraints. These constraints, called threshold volumes, were selected to ensure security of re-stored or exchanged water from the threat of reservoir spill when reservoir levels are high or the threat of limited outlet capacity, recreation potential, or water category availability when reservoir levels are low.
Enhanced minimum-flow targets would be set to one of two levels, depending on whether the current season is defined as a normal season or a dry season. The designation of a season as normal or dry would be dependent upon the magnitude of pooled water stored in Lake Tahoe and the current April-through-July forecast of Truckee River Basin natural flow in the river at the California-Nevada State boundary (see subsequent section "Determination of Normal and Dry Season"). Note that wetter-than- average conditions would place enhanced minimum-flow targets at those defined for a "normal season." These seasons were established as a method to integrate forecasting and current quantity of flow into the determination of enhanced minimumflow targets. This method assures that water rights will not be impaired while improving the prospects of enhancing minimum instream flow.

Several reservoirs in the Truckee River Basin would be operated to provide releases necessary to maintain enhanced instream flows just downstream from the reservoirs. The following list describes the flow targets for each reservoir as specified in the draft TROA (Bureau of Reclamation and others, 1998):

- Lake Tahoe-Enhanced minimum-flow target for a normal season is $75 \mathrm{ft}^{3} / \mathrm{s}$. Draft TROA credit water categories will be released to supplement the existing minimum-flow targets to the extent that the draft TROA credit water categories can be exchanged to another reservoir. During a dry season, if pooled water is not sufficient to maintain the existing minimum-flow targets, then draft TROA water categories will be combined with the existing pooled water release for a total of $37.5 \mathrm{ft}^{3} / \mathrm{s}$ to the extent that the draft TROA credit water categories can be exchanged to another reservoir. No draft TROA credit water categories will be released if pooled water release is greater than $37.5 \mathrm{ft}^{3} / \mathrm{s}$ but less than the existing minimum-flow targets.

- Donner Lake-Enhanced minimum-flow target for a normal season is $8 \mathrm{ft}^{3} / \mathrm{s}$ and $4 \mathrm{ft}^{3} / \mathrm{s}$ during a dry season. PCPOSW and TCIDPOSW will each contribute up to one-half the total toward the release to supplement the existing minimum-flow targets of $2-3 \mathrm{ft}^{3} / \mathrm{s}$, provided these categories can be exchanged to another reservoir.

- Martis Creek Lake-Enhanced minimum-flow releases from Martis Creek Lake are not required. 
- Prosser Creek Reservoir-Enhanced minimumflow target for a normal season is $16 \mathrm{ft}^{3} / \mathrm{s}$. Uncommitted water will supplement the existing minimum-flow target of $5 \mathrm{ft}^{3} / \mathrm{s}$ up to an intermediate enhanced target of $10 \mathrm{ft}^{3} / \mathrm{s}$, provided that either (1) it be exchanged to another reservoir, or (2) the release of Stampede Reservoir fish water be reduced by an equal amount. Draft TROA water categories will then be released as necessary to increase the enhanced minimum-flow release to $16 \mathrm{ft}^{3} / \mathrm{s}$ if the draft TROA categories can be exchanged to another reservoir. During a dry season, the enhanced minimum-flow target is $8 \mathrm{ft}^{3} / \mathrm{s}$ at Prosser Creek Reservoir. Uncommitted water will supplement the existing minimumflow target of $5 \mathrm{ft}^{3} / \mathrm{s}$, provided (1) it can be exchanged to another reservoir, or (2) the release of Stampede Reservoir fish water can be reduced by an equal amount. If necessary, draft TROA credit water categories will be released to attain the $8 \mathrm{ft}^{3} / \mathrm{s}$ enhanced target if these categories can be exchanged to another reservoir.

- Independence Lake-Enhanced minimum-flow targets range from 2 to $8 \mathrm{ft}^{3} / \mathrm{s}$ during the normal season and from 2 to $4 \mathrm{ft}^{3} / \mathrm{s}$ during the dry season (table 7). PCPOSW water will supplement the existing minimum-flow target of $2 \mathrm{ft}^{3} / \mathrm{s}$ when the enhanced flow target is greater than $2 \mathrm{ft}^{3} / \mathrm{s}$. Although it is not necessary to exchange releases for the enhanced flow target to another reservoir, such releases may be re-stored in downstream reservoirs.

- Stampede Reservoir-Enhanced minimum-flow target for a normal season is $45 \mathrm{ft}^{3} / \mathrm{s}$. All water categories in storage except firm PCMICW, PCEDS, and TPEW will be released to supplement the existing flow target of $30 \mathrm{ft}^{3} / \mathrm{s}$ if these categories can be exchanged to another reservoir or re-stored in Boca Reservoir. However, as discussed for Prosser Creek Reservoir, the existing flow target for Stampede Reservoir may be reduced by up to $5 \mathrm{ft}^{3} / \mathrm{s}$ to provide enhanced minimum flows downstream from Prosser Creek Reservoir. During a dry season, if fish water is not sufficient to maintain the existing flow target of $30 \mathrm{ft}^{3} / \mathrm{s}$, then the water categories, as discussed above, will be released to enhance the existing fish water release to $22.5 \mathrm{ft}^{3} / \mathrm{s}$ to the extent that the waters can be exchanged to another reservoir or re-stored in Boca Reservoir. No draft TROA credit water categories will be released if the existing release is greater than $22.5 \mathrm{ft}^{3} / \mathrm{s}$ but less than the existing $30 \mathrm{ft}^{3} / \mathrm{s}$ minimum-flow target.

- Boca Reservoir-Enhanced minimum-flow releases from Boca Reservoir are not required.

Releases for maintenance of enhanced minimum instream flows are simulated in the USGS Truckee River Basin operations model as follows. Model code in the subblock initial assignments and computations determines initial values of proposed releases to meet enhanced minimum flows. The assignments specified for Lake Tahoe, Donner and Independence Lakes, and Prosser and Stampede Reservoirs are based on whether it is a normal or dry season. Assignments of enhanced minimum flows for Independence Lake are based also on the current month and reservoir storage.

The proposed reservoir releases for maintenance of enhanced minimum flows are modified in the subblock enhanced minimum instream flows, based on various rules and constraints for those reservoirs required to release for enhanced minimum flows. In this subblock, enhanced minimum instream flows are based on whether (1) water categories involved in the releases can be re-stored in another reservoir, (2) the water categories can be exchanged with other water categories in another reservoir, or (3) specified water categories are available, such as JPFCW, that do not require re-storage or exchange into other reservoirs. The following discussion describes how the model code in the subblock enhanced minimum instream flows modifies the initial numerical values of required reservoir releases to maintain enhanced minimum flows.

First, the status of reservoir releases is compared to enhanced minimum-flow targets for those reservoirs required to maintain enhanced minimum flows. The releases from these reservoirs correspond to flows just downstream from the reservoir outlets. If a given release is less than the target, then the deficit is determined as that additional flow of water needed to achieve the flow target. Likewise, if a given release is greater than the target, the excess is determined to eliminate unnecessary releases.

Second, for each reservoir with a release less than the enhanced flow target (release deficit), the model determines the potential for additional releases. The availability of additional releases is based on the vol- 
Table 7. Independence Lake enhanced minimum flow targets

[Abbreviation: $\mathrm{ft}^{3} / \mathrm{s}$, cubic feet per second]

\begin{tabular}{|c|c|c|c|c|c|}
\hline $\begin{array}{l}\text { Storage (acre-feet) } \\
\text { and season type }\end{array}$ & $\begin{array}{c}\text { January } \\
\left(\mathrm{ft}^{3} / \mathrm{s}\right)\end{array}$ & $\begin{array}{c}\text { February-March } \\
\left(\mathrm{ft}^{3} / \mathrm{s}\right)\end{array}$ & $\begin{array}{c}\text { April-July } \\
\left(\mathrm{ft}^{3} / \mathrm{s}\right)\end{array}$ & $\begin{array}{c}\text { August-September } \\
\left(\mathrm{ft}^{3} / \mathbf{s}\right)\end{array}$ & $\begin{array}{c}\text { October-December } \\
\left(\mathrm{ft}^{3} / \mathrm{s}\right)\end{array}$ \\
\hline \multicolumn{6}{|l|}{ Less than or equal to 7,500 : } \\
\hline Normal and dry season & 2 & 2 & 2 & 2 & 2 \\
\hline \multicolumn{6}{|c|}{ Greater than 7,500 and less than or equal to 12,500 : } \\
\hline Normal and dry season & 3.5 & 2 & 4 & 2 & 3.5 \\
\hline \multicolumn{6}{|l|}{ Greater than 12,500: } \\
\hline Normal season & 7 & 4 & 8 & 4 & 7 \\
\hline Dry season & 3.5 & 2 & 4 & 2 & 3.5 \\
\hline
\end{tabular}

ume of specific water categories available for release in accordance to the criteria described previously, as specified in draft TROA (Bureau of Reclamation and others, 1998), and hydraulic constraints of the reservoir outlet. Additional releases of specific water categories are based on the proportion of a given category volume to the total volume of water categories available for additional release. Mandatory exchange criteria for Donner Lake require minimum threshold volumes, and as a result, enhanced instream flow releases may be restricted from the lake if volumes are less than the minimum threshold volumes. For each reservoir, the model checks the following water categories for contribution to enhanced releases.

- Lake Tahoe-WQCW, fish credit water, and nonfirm PCMICW.

- Donner Lake-PCPOSW (for simulations, TCIDPOSW is not used to achieve enhanced instream flow targets).

- Martis Creek Lake—not applicable.

- Prosser Creek Reservoir-uncommitted, WQCW, nonfirm PCMICW, and fish credit water.

- Independence Lake-PCPOSW.

- Stampede Reservoir-fish water, PCPOSW, pooled water, WQCW, nonfirm PCMICW, and fish credit water.

- Boca Reservoir-not applicable.

Third, for each reservoir with a release greater than the enhanced flow target (release excess), the model determines the amount that releases from given water categories may be decreased. For in-lieu-of exchanges, the water categories in reservoirs with release excesses can be exchanged with water categories in those reservoirs with release deficits. The amount of reduction in releases of a given water category is based on the difference between the currently simulated release and the required minimum release (release floor). As previously discussed, release floors are of two types: overall and category. Overall release floors are based on releases that do not require specific category releases, such as releases for existing minimum-flow targets and releases for uncontrolled spills or precautionary drawdowns. Category release floors are based on specific categories that are involved in previously simulated exchanges, such as the TahoeProsser Exchange, as discussed in the section "TahoeProsser Exchange." In addition to the consideration of release floors, the reduction of releases is based on the proportion of each water category released to the total release of water categories available for reduction and whether the reservoir volume is greater than its maximum threshold volume. Finally, mandatory exchange criteria for Lake Tahoe and Prosser, Stampede, and Boca Reservoirs require maximum threshold volumes, and as a result, reduction of releases will be restricted in these reservoirs if volumes are greater than the maximum threshold volumes. Designated minimum threshold volumes for Lake Tahoe will restrict reduction of releases if the storage volume is less than a given minimum threshold volume. For each reservoir where a release excess is computed, the following water categories are checked to determine if releases can be reduced.

- Lake Tahoe-fish credit water, nonfirm PCMICW, WQCW, and pooled water. 
- Donner Lake-not applicable. (For simulations, no credit waters are exchanged into this reservoir, and as a consequence, reservoir releases are not reduced for in-lieu-of exchanges).

- Martis Creek Lake—not applicable.

- Prosser Creek Reservoir-fish credit water, nonfirm PCMICW, WQCW, uncommitted water, Tahoe-Prosser Exchange water, and natural water.

- Independence Lake-not applicable (For simulations, no credit waters are exchanged into this reservoir and, as a consequence, reservoir releases are not reduced for in-lieu-of exchanges.)

- Stampede Reservoir-not applicable (Credit water categories are first exchanged into Boca Reservoir and subsequently exchanged into Stampede Reservoir in other types of exchanges. See the later section "Voluntary Exchanges.")

- Boca Reservoir-fish credit water, WQCW, nonfirm PCMICW, PCPOSW, fish water, adverseto-canal pooled water, non-adverse-to-canal pooled water, and natural water.

Fourth, determine release increases for those reservoirs that require and are capable of such releases for the enhanced instream flow targets. As discussed above, the enhanced releases may be restricted depending on the minimum and maximum threshold volumes of given reservoirs. Three methods are used to determine enhanced releases: (1) re-storage of water categories in another reservoir, (2) in-lieu-of exchange of water categories to another reservoir, and (3) release of specific water categories when available, such as JPFCW, without re-storage or exchange. For the inlieu-of exchange method (item 2), potential release increases of water categories from reservoirs must be compared with potential release reductions of water categories from different reservoirs. The other two methods do not require such a comparison. At a given reservoir, if enhanced instream flows cannot be met by re-storage or exchange in another reservoir, then JPFCW is released.

The operations model simulates reservoir releases for enhanced minimum-flow targets by the three methods listed above according to the following list. The list is based on a rank order of probable releases for enhanced instream flow (Lake Tahoe, Stampede Reservoir, Prosser Creek Reservoir, Independence Lake, and
Donner Lake). Unless indicated, water categories involved in release increases and decreases are those previously discussed in this section.

\section{Lake Tahoe}

In-lieu-of exchanges:

- Lake Tahoe release increase concurrent with Prosser Creek Reservoir release decrease. Water categories listed above for Lake Tahoe enhanced releases are exchanged with categories used to reduce Prosser Creek Reservoir releases.

- Lake Tahoe release increase concurrent with Boca Reservoir release decrease. Water categories listed above for Lake Tahoe enhanced releases are exchanged with categories used to reduce Boca Reservoir releases.

Release with no exchange or re-storage:

- Lake Tahoe release increase of JPFCW.

\section{Stampede Reservoir}

Re-storage:

- Stampede Reservoir release increase with Boca Reservoir re-storage of water categories listed above for enhanced releases

\section{In-lieu-of exchanges:}

- Stampede Reservoir and corresponding Boca Reservoir release increases concurrent with Lake Tahoe release decrease. Water categories listed above for Stampede enhanced releases are exchanged with categories used to reduce Lake Tahoe releases. The increased release from Stampede is passed through Boca to meet the same demands downstream on the Truckee River as would have been satisfied by releases from Lake Tahoe prior to an exchange.

- Stampede Reservoir and corresponding Boca Reservoir release increases concurrent with Prosser Creek Reservoir release decrease. Water categories listed above for Stampede Reservoir enhanced releases are exchanged with categories used to reduce Prosser Creek Reservoir releases. As described above, the increased release from Stampede is passed 
through Boca to meet the same demands downstream on the Truckee River as would have been satisfied by releases from Prosser prior to an exchange.

Release with no exchange or re-storage:

- Stampede Reservoir release increase of JPFCW.

\section{Prosser Creek Reservoir}

In-lieu-of exchanges:

- Prosser Creek Reservoir release increase of uncommitted water concurrent with Lake Tahoe release decrease. The uncommitted water from Prosser Creek Reservoir is exchanged with water categories used to reduce Tahoe releases.

- Prosser Creek Reservoir release increase of uncommitted water concurrent with Boca Reservoir release decrease. The uncommitted water from Prosser Creek Reservoir is exchanged with water categories used to reduce Boca releases.

- Prosser Creek Reservoir release increase of uncommitted water concurrent with Stampede Reservoir release decrease of fish water. There is no exchange of water categories between the two reservoirs because uncommitted water is commonly used for similar objectives as fish water, such as cui-ui fish runs. However, there is an exchange of release quantities between the two reservoirs.

- Prosser Creek Reservoir release increase of appropriate categories other than uncommitted water concurrent with Lake Tahoe release decrease. Water categories, other than uncommitted water, listed above for Prosser Creek Reservoir enhanced releases are exchanged with categories used to reduce Tahoe releases.

- Prosser Creek Reservoir release increase of appropriate categories other than uncommitted water concurrent with Boca Reservoir release decrease. Water categories, other than uncommitted water, listed above for Prosser Creek Reservoir enhanced releases are exchanged with categories used to reduce Boca releases.

Release with no exchange or re-storage:

- Prosser Creek Reservoir release increase of JPFCW.

\section{Independence Lake}

Re-storage:

- Independence Lake release increase of PCPOSW with Stampede Reservoir or Boca Reservoir re-storage.

\section{Donner Lake}

In-lieu-of exchanges:

- Donner Lake release increase concurrent with Lake Tahoe release decrease. Water categories listed above for Donner Lake enhanced releases are exchanged with categories used to reduce Tahoe releases.

- Donner Lake release increase concurrent with Prosser Creek Reservoir release decrease. Water categories listed above for Donner Lake enhanced releases are exchanged with categories used to reduce Prosser Creek Reservoir releases.

- Donner Lake release increase concurrent with Boca Reservoir release decrease. Water categories listed above for Donner Lake enhanced releases are exchanged with categories used to reduce reservoir releases.

Several assumptions were made in this subblock.

- Because of the large number of categories available for releases from reservoirs for enhanced minimum-flow targets, a large number of exchanges are possible. The USGS Truckee River Basin operations model simulates only the most likely water categories and exchanges that would be used to attain or maintain enhanced instream flows.

- Additional releases from Prosser Creek Reservoir to prevent the formation of ice that could reduce instream flows in Prosser Creek are specified in draft TROA. These releases are not simulated in the operations model. 
- If simulated releases from Donner Lake are not adequate for maintenance of enhanced minimumflow targets, only PCPOSW is simulated to provide all water necessary toward maintenance of enhanced minimum-flow targets, provided it can be exchanged to another reservoir. Although stored in Donner Lake, TCIDPOSW is not simulated to contribute toward enhanced minimumflow targets.

- If simulated releases from Independence Lake are not adequate for maintenance of enhanced minimum-flow targets, only PCPOSW in the lake is simulated to provide water for enhanced minimum-flow targets.

- Instream flows in reaches of the Truckee River between hydropower diversion and return points are specified in draft TROA. Except for the Truckee River downstream from Lake Tahoe, enhanced flow targets along the mainstem Truckee River are not simulated.

- If available, JPFCW will be released from a given reservoir if enhanced minimum-flow targets cannot be met by releases that require exchange or restorage in another reservoir.

- Maximum and minimum reservoir threshold volumes are simulated as constant daily values throughout a month rather than as interpolated values between end-of-month values specified in draft TROA. The reservoir levels used for comparison with the threshold volumes are the current day's simulated volume, not a forecasted volume. Neither forecasted volumes nor seasonal foresight ${ }^{10}$ were used in determining the exchanges for maintenance of enhanced minimum-flow targets (see section "Model Limitations, Assumptions, and Suggested Improvements" for a discussion on the subject of foresight).

- Reservoirs not located on the Little Truckee River are not simulated to exchange directly into Stampede Reservoir. Such exchanges are first made directly into Boca Reservoir for later exchange into Stampede (see subsequent section "Voluntary Exchanges").

\footnotetext{
${ }^{10}$ Seasonal foresight utilizes forecasts of both inflow and reservoir management to construct an operational forecast.
}

- Water categories may change during a simulated exchange into another reservoir. The following list illustrates those water category changes for exchanges to meet enhanced minimum-flow targets.

1. Uncommitted water changes to fish credit water when exchanged from Prosser Creek Reservoir to storage in another reservoir.

2. PCPOSW changes to nonfirm PCMICW when an exchange is simulated from Donner Lake to storage in another reservoir.

\section{Other Exchanges and Transfers}

Other mandatory exchanges and transfers specified in draft TROA (Bureau of Reclamation and others, 1998) are based on category storage limits, drought situation, time of the year, or some combination of these criteria. These other exchanges and transfers are used to maintain base amounts of firm PCMICW, nonfirm PCMICW, and PCEDS and to transfer (1) PCPOSW to PCMICW and (2) PCMICW to fish credit water on specific dates. Base amounts of PCMICW are described in the section "Proposed Water Categories."

The following is a list of these other mandatory exchanges and transfers, which are simulated in the USGS Truckee River Basin operations model in the subblock TROA mandatory exchanges. Note that the term drought situation has a specific meaning in draft TROA and its determination is prerequisite to many operations including some of the operations listed below. It is described in the section "Drought Situations." Following the list is a detailed explanation of each of the mandatory exchanges or transfers.

1. Create firm PCMICW in Stampede Reservoir when firm PCMICW storage falls below its base amount by transfer of nonfirm PCMICW in Stampede to firm PCMICW storage.

2. Create PCEDS in Stampede Reservoir when PCEDS storage falls below its base amount during a nondrought situation by transfer of fish credit water in Stampede to PCEDS or re-storage exchange of Independence Lake PCPOSW to Stampede PCEDS, when requested by the Power Company.

3. Move nonfirm PCMICW to Stampede Reservoir from other reservoirs when the volume of non- 
firm PCMICW in Stampede falls below its base amount during a drought situation between July 1 to April 1 by paper exchange of nonfirm PCMICW in Lake Tahoe, Prosser Creek Reservoir, and Boca Reservoir with fish and fish credit water storage in Stampede.

4. Move nonfirm PCMICW to Stampede Reservoir from other reservoirs to attain an additional 6,000 acre- $\mathrm{ft}$ of storage of nonfirm PCMICW (based on the consumptive use portion of former agricultural rights) in Stampede, during a drought situation between the dates of April 15 and July 1 (base amounts are not considered for this exchange). This move will be achieved by paper exchange of nonfirm PCMICW in Lake Tahoe and Boca and Prosser Reservoirs with fish water or fish credit water storage in Stampede.

5. Create firm PCMICW in Stampede Reservoir when the volume of firm PCMICW in Stampede falls below its base amount during a nondrought situation between July 1 to December 31. Firm PCMICW will be created by paper exchange of PCMICW in Lake Tahoe and Prosser and Boca Reservoirs with fish or fish credit water storage in Stampede.

6. Create fish credit water in Prosser Creek Reservoir, Lake Tahoe, and Boca and Stampede Reservoirs when the storage volume of nonfirm PCMICW is above the base amount on April 1 during a nondrought situation. Fish credit water will be created by transfer of nonfirm PCMICW in Prosser, Tahoe, Boca, and Stampede to fish credit water. During a drought situation, this transfer will not occur.

7. Create PCMICW in Stampede Reservoir or Boca Reservoir by transfer of PCPOSW to PCMICW on January 1.

\section{Firm PCMICW in Stampede Reservoir when firm PCMICW storage falls below its base amount}

The operations model simulates the transfer of nonfirm to firm PCMICW in item 1 by first comparing the amount of firm PCMICW to the base amount for that category. If the storage of firm PCMICW in Stampede Reservoir falls below its base amount and nonfirm PCMICW exists in the reservoir, then transfer the amount of nonfirm PCMICW to firm PCMICW in the reservoir up to the base amount for firm PCMICW. In draft TROA, this transfer is not specified. For model simulations, this transfer maintains the base amount of firm PCMICW in Stampede. Any remaining amount of PCMICW simulated in Stampede is stored as nonfirm PCMICW.

PCEDS in Stampede Reservoir when PCEDS storage falls below its base amount during a nondrought situation

The operations model simulates exchanges for creation of PCEDS in item 2 by first comparing the amount of PCEDS in Stampede Reservoir to the base amount (7,500 acre- $\mathrm{ft}$ ) for that category, and then determining PCEDS category transfers. When the storage of PCEDS falls below its base during a nondrought situation, the volume necessary to achieve the base amount is exchanged from available sources. The simulation is based on the date and conditions in the following order listed below:

- Transfer fish credit water in Stampede Reservoir to PCEDS water in Stampede.

- Re-storage exchange by release of PCPOSW in Independence Lake to Stampede Reservoir if the lake storage is above the recreational pool level (see section "Maintenance of Recreational Pools") and Independence releases are below the preferred flow target releases (see section "Preferred Instream Flows"). Exchange PCPOSW in Stampede Reservoir to PCEDS in the reservoir.

- Transfer PCPOSW in Stampede Reservoir to PCEDS water in the reservoir.

The assumptions used in subblock TROA mandatory exchanges are as follows:

- For simulations, only the transfers and re-storage exchanges between waters in Stampede Reservoir listed above are used to create PCEDS water in Stampede, even though other exchanges are possible between waters in Boca and Stampede Reservoirs.

- The draft TROA states that the first 7,500 acre-ft of Power Company's credit water in Stampede Reservoir transferred to fish credit water shall become the PCEDS. PCEDS is created in the model from fish credit water as described above. It is assumed that once initially created, PCEDS will only be used during extreme droughts, and 
therefore additional PCEDS creation will be infrequent.

Nonfirm PCMICW to Stampede Reservoir from other reservoirs when the volume of nonfirm PCMICW in Stampede Reservoir falls below its base amount during a drought situation between July 1 and April 1

The operations model simulates the paper exchange to accumulate additional nonfirm PCMICW in Stampede Reservoir in item 3 by first comparing the amount of nonfirm PCMICW to the base amount for that category. If a drought situation exists, and the current date is between July 1 and April 1, and if the storage of nonfirm PCMICW in the reservoir falls below its base amount, then paper exchanges are simulated to bring nonfirm PCMICW storage up to the base amount in the order below.

- Paper-exchange nonfirm PCMICW in Lake Tahoe and Prosser and Boca Reservoirs with fish credit water in Stampede Reservoir.

- Paper-exchange nonfirm PCMICW in Lake Tahoe and Prosser and Boca Reservoirs with fish water in Stampede Reservoir.

The draft TROA states that the Power Company can exchange or displace fish credit water or fish water in Stampede Reservoir from July 1 to the following April 1 to the extent necessary to enable the Power Company to store the base amounts of firm and nonfirm M\&I credit water. It is assumed that nonfirm PCMICW storage up to the base amount is simulated in the model as described in item 3. Firm PCMICW storage up to the base amount is simulated using the transfer described in item 1. For a further discussion on displacement, see the section "Merge Reservoir Releases for Multiple Objectives."

Note that if firm PCMICW volume is less than its base amount in Stampede Reservoir during a drought situation between July 1 and April 1, these paper exchanges provide a mechanism to accumulate additional nonfirm PCMICW from which firm PCMICW can be credited as described in item 1 above.

Nonfirm PCMICW to Stampede Reservoir from other reservoirs to attain an additional 6,000 acre-ft of storage of nonfirm PCMICW in Stampede Reservoir during a drought situation between the dates of April 15 and July 1
The operations model simulates the paper exchange to accumulate nonfirm PCMICW in Stampede Reservoir as described in item 4 by first comparing the amount of nonfirm PCMICW stored in the reservoir since April 15 to 6,000 acre-ft (as stipulated in the draft TROA (Bureau of Reclamation and others, 1998) and determining the presence or absence of a drought situation. If in a drought situation, between April 15 and July 1, and if storage of nonfirm PCMICW in the reservoir since April 15 is less than 6,000 acre-ft, then the paper exchanges below are simulated.

- Paper-exchange nonfirm PCMICW in Prosser Creek Reservoir, Lake Tahoe, and Boca Reservoir with fish credit water in Stampede Reservoir.

- Paper-exchange nonfirm PCMICW in Prosser Creek Reservoir, Lake Tahoe, and Boca Reservoir with fish water in Stampede Reservoir.

Firm PCMICW in Stampede Reservoir when the volume of firm PCMICW in Stampede Reservoir falls below its base amount during a nondrought situation between July 1 and December 31

The paper exchange to accumulate firm PCMICW as described in item 5 by first comparing the amount of firm PCMICW in Stampede Reservoir to its base amount and determining the presence or absence of a drought situation. If a nondrought situation exists, and the current date is between July 1 and December 31 , and if the storage of firm PCMICW in the reservoir falls below its base amount, then paper exchanges are simulated to increase nonfirm PCMICW storage in the reservoir using the operations below.

- Paper-exchange nonfirm PCMICW in Lake Tahoe and Prosser and Boca Reservoirs with fish credit water in Stampede Reservoir.

- Paper-exchange nonfirm PCMICW in Lake Tahoe and Prosser and Boca Reservoirs with fish water in Stampede Reservoir.

The draft TROA states that the Power Company shall have the first right to store firm M\&I credit water in Stampede Reservoir from the previous July 1 through December 31 up to the base amount of firm M\&I credit water. For the model, it is assumed that nonfirm PCMICW storage is simulated by paper exchanges in the model as just described, and firm PCMICW storage up to the base amount is simulated 
using the transfer described in item 1. As stated in the section "Storage of Proposed Water Categories," nonfirm PCMICW will be accumulated by a reduction of releases used to maintain Floriston rates corresponding to the daily consumptive use of the former agricultural diversion rights. That accumulation of credit water is different than the paper exchanges described in item 5 .

\section{Fish credit water in Prosser Creek Reservoir, Lake} Tahoe, and Boca and Stampede Reservoirs when the storage volume of nonfirm PCMICW is above the base amount on April 1 during a nondrought situation.

The operations model simulates the transfer of nonfirm PCMICW to fish credit water in item 6 by first comparing the amount of nonfirm PCMICW to the base amount for that category and determining the presence or absence of a drought situation. When not in a drought situation and if the April 1 storage of nonfirm PCMICW in reservoirs is greater than the base amount, the excess nonfirm PCMICW is transferred to fish credit water. Those transfers simulated by the operations model include the transfer of nonfirm PCMICW in Prosser Creek Reservoir, Lake Tahoe, Boca Reservoir, and Stampede Reservoir in that rank order to fish credit water in those same reservoirs.

\section{PCMICW in Stampede or Boca Reservoirs by transfer} of PCPOSW to PCMICW on January 1

The operations model simulates the transfer of PCPOSW and PCMICW as described in item 7. Under draft TROA, PCPOSW in reservoirs other than Donner and Independence Lakes shall retain its classification as PCPOSW until December 31, after which time it transfers to PCMICW. If PCPOSW is being stored in Stampede or Boca Reservoirs on January 1, then a transfer of PCPOSW to nonfirm PCMICW is made in the following reservoirs:

- Transfer PCPOSW to nonfirm PCMICW in Stampede Reservoir.

- Transfer PCPOSW in excess of 800 acre-ft (Boca Reservoir PCPOSW level) to nonfirm $\mathrm{PCMICW}$ in Boca.

The assumptions used in this section are as follows:

- Storage of PCPOSW is not simulated in Lake Tahoe and Prosser Creek Reservoir.
- Under current operations, as described in the previous section, "Privately Owned Stored Water," the Power Company stores PCPOSW in Boca Reservoir in accordance with rules in the Truckee River Agreement, and may store additional PCPOSW in Boca and Stampede Reservoirs as described in the Interim Storage Agreement. Under draft TROA, storage of PCPOSW in Boca and Stampede Reservoirs as defined by the Interim Storage Agreement will be superseded by credit water operations. The operations model code reflects these differences between current and draft TROA reservoir management.

The assumptions used in this section, "Other Exchanges and Transfers," are as follows.

- Forecasting reservoir levels could provide a more realistic estimate of the probability of losing certain water categories to reservoir spills. Current reservoir levels are used in the model for the exchanges listed in this section.

- Storage of nonfirm PCMICW is not simulated for Independence and Donner Lakes in the model.

\section{Voluntary Exchanges}

Under the draft TROA and WQSA operations, exchanges are used for moving water of various categories among the reservoirs. Many of these exchanges would be voluntary and the criteria that might trigger these exchanges are not specified in the draft TROA. Voluntary exchanges would be requested by the interested parties and the terms and conditions would be agreed to by the parties. Voluntary exchanges would not interfere with the storage or release of current waters associated with any reservoir. Also, no voluntary exchanges would interfere with the achievement of minimum instream flows or the mandatory exchanges described in the section "Mandatory Exchanges and Transfers." Voluntary exchanges allow scheduled releases to meet several objectives instead of one, such as (1) preferred instream flows, (2) enhanced storage security, (3) efficient use of releases for precautionary drawdowns, and (4) maintenance of recreational pools. The following sections describe these exchanges and how the USGS Truckee River operations model simulates them. 
Table 8. Assumed preferred instream flow targets downstream of reservoirs

[Abbreviation: $\mathrm{ft}^{3} / \mathrm{s}$, cubic feet per second]

\begin{tabular}{|c|c|c|c|c|c|}
\hline Location & $\begin{array}{c}\text { January } \\
\left(\mathrm{ft}^{3} / \mathrm{s}\right)\end{array}$ & $\begin{array}{c}\text { February-March } \\
\left(\mathrm{ft}^{3} / \mathrm{s}\right)\end{array}$ & $\begin{array}{l}\text { April-July } \\
\left(\mathrm{ft}^{3} / \mathrm{s}\right)\end{array}$ & $\begin{array}{c}\text { August-September } \\
\left(\left(\mathrm{ft}^{3} / \mathbf{s}\right)\right.\end{array}$ & $\begin{array}{l}\text { October-December } \\
\qquad\left(\mathrm{ft}^{3} / \mathrm{s}\right)\end{array}$ \\
\hline Lake Tahoe & 250 & 150 & 300 & 150 & 2,502 \\
\hline Donner Lake & 50 & 20 & 50 & 10 & 50 \\
\hline Martis Creek Lake $^{1}$ & - & - & - & - & - \\
\hline Prosser Creek Reservoir & 50 & 35 & 75 & 30 & 50 \\
\hline Independence Lake & 20 & 10 & 20 & 10 & 20 \\
\hline Stampede Reservoir & 125 & 100 & 125 & 100 & 125 \\
\hline Boca Reservoir ${ }^{2}$ & - & - & - & - & - \\
\hline
\end{tabular}

\footnotetext{
${ }^{1}$ Maintenance of preferred instream flows downstream from Martis Creek Lake is not required.
}

${ }^{2}$ Maintenance of preferred instream flows downstream from Boca Reservoir is not required.

\section{Preferred Instream Flows}

Under draft TROA, guidelines for preferred instream flows further increase flow targets described in the previous sections "Instream Flows and Enhanced Minimum Instream Flows." Preferred instream flow targets (hereafter referred to as preferred flows) vary by season and location, and Truckee River system operators would attempt to achieve these targets only when practicable through exchanges and scheduling of releases consistent with water rights. The preferred flow targets would help to better serve fish and recreational interests. Draft TROA would provide opportunities for using credit and POSW waters to increase the flow rates beyond mandatory enhanced minimum instream flows (see previous discussion in the section "Enhanced Minimum Instream Flows") to the rates prescribed for voluntary preferred flows. These water categories could be used to increase instream flows only if they could be re-stored in another reservoir or exchanged for water in another reservoir. As was the case for enhanced minimum instream flows, exchanges made to attain the higher targets for preferred flows depend on the water category's security in storage when re-stored or exchanged, its availability and location in reservoir storage before re-storage or exchange, and the current status of streamflow with respect to preferred flow targets at specific locations. Similar to enhanced minimum instream flows, California, at its discretion, could use Joint Program fish credit water (JPFCW) to achieve preferred flows without restorage or exchange into another reservoir.

As with other mandatory exchanges, the current storage within reservoirs targeted for re-storage or exchange to facilitate preferred flows needs to be within prescribed thresholds. These threshold vol- umes were developed to ensure security of re-stored or exchanged water with regard to the threat of reservoir spill when reservoir levels are high or the threat of limited outlet capacity or recreation potential when reservoir levels are low. Unlike enhanced instream flow guidelines, normal and dry seasons are not used to determine preferred flow targets.

Several reservoirs in the Truckee River Basin would be operated to provide releases necessary for the maintenance of preferred flows, which are not specified by draft TROA. Rather, draft TROA indicates that the State of California will submit operating guidelines, called "California Guidelines," that will address preferred flows below reservoirs. It is anticipated that the guidelines will address many concerns, and thus provide a degree of flexibility for the determination of preferred flow targets and the methods to achieve them. However, for purposes of model simulations, table 8 specifies assumed preferred flows below each reservoir (Roderick L. Hall, Sierra Hydrotech, written commun., p. 4, August 23, 1996).

The USGS Truckee River Basin operations model simulates preferred flow exchange operations as follows. Like the simulation of reservoir releases for maintenance of enhanced minimum instream flow targets, reservoir releases for maintenance of preferred flows are simulated in two subblocks of the operations model. The subblock initial assignments and computations assigns proposed releases for each reservoir for maintenance of preferred flows. The subblock preferred instream flows modifies the proposed releases by applying various rules and constraints required for reservoir releases and exchanges for preferred flows.

In the subblock initial numerical assignments and computations, the following are specified. 
- The user specifies whether releases and exchanges to maintain preferred flow targets downstream from reservoirs will be simulated or not. If so, the user also specifies, on a reservoirby-reservoir basis, whether releases and exchanges to maintain preferred flow targets downstream from each reservoir will be simulated or not.

- Preferred flow objectives are specified for Donner and Independence Lakes, Stampede and Prosser Reservoirs, and Lake Tahoe based on the month (table 8 ). These values may be changed by the user. Boca Reservoir and Martis Creek Lake have no preferred flow targets.

- Once the option to simulate preferred flows has been selected, the user may choose one of three options for preferred flow targets:

1. Simulate preferred flows at the full target levels (table 8), even if only for a short period of time, until available credit and POSW waters are depleted.

2. Reduce the target flow rates to extend the flow increase over enhanced minimum instream flows through the summer, based on the current storage of JPFCW in a reservoir.

3. Reduce the target flow rates to extend the flow increase over enhanced minimum instream flows as described in item 2. However, the target flow rates will be based on the current storage of nonfirm Power Company M\&I credit water (nonfirm PCMICW), fish credit water, water-quality credit water (WQCW), and Power Company POSW (PCPOSW) in addition to JPFCW in a reservoir.

If option 2 or 3 is selected, rather than maintaining full-target flows for a short period (table 8), the computations associated with these options would simulate maintenance of a lower target flow throughout the summer when reservoir storage of water categories would otherwise be insufficient. Thus, these two options will simulate reservoir releases designed to extend a lower rate of preferred flows over longer periods of time.

The reservoir releases for achievement of full or reduced preferred flow targets in the initial numerical assignments and computations subblock are modified in the subblock preferred instream flows. Hereafter, for clarity of discussion, "full" or "reduced" preferred flow targets will be referred to simply as "preferred" flow targets. This subblock modifies the proposed releases by applying various rules and constraints for all reservoirs required to release for preferred flows. In this subblock, reservoir releases to maintain preferred flow targets are based on whether (1) water categories involved in the releases can be re-stored in another reservoir, (2) water categories can be exchanged with other water categories in another reservoir, or (3) JPFCW, which does not require re-storage or exchange into other reservoirs, is available.

First, the status of reservoir releases is compared to preferred flow targets downstream from the reservoirs. If a given release is less than the target, then the deficit is determined as that additional flow needed to achieve the preferred flow target. Likewise, if a given release is greater than the target, the excess is determined so that releases may be reduced to target rates, if possible.

Second, when the reservoir release is less than the preferred flow target, the availability of water categories for additional releases is determined while considering the hydraulic constraints of the reservoir outlet. Additional releases of waters are based on the proportion of a given category volume to the total volume of water categories available for additional release. As discussed above, minimum threshold volumes are required for Donner Lake for security of exchanged waters or for maintenance of recreational pool levels, and as a result, releases for preferred flows may be restricted from the lake. For each reservoir the availability of the following water categories is checked for preferred flow releases:

- Lake Tahoe-WQCW, fish credit water, and nonfirm PCMICW.

- Donner Lake-PCPOSW. For simulations, TCIDPOSW is not used to achieve enhanced instream flow targets.

- Martis Creek Lake—not applicable.

- Prosser Creek Reservoir-WQCW, fish credit water, and nonfirm PCMICW.

- Independence Lake-PCPOSW.

- Stampede Reservoir-WQCW, fish credit water, and nonfirm PCMICW.

- Boca Reservoir-not applicable. 
Third, for each reservoir with a release excess, a determination is made regarding the amount releases from given water categories may be decreased. Water categories in reservoirs with release excesses can be exchanged with water categories in those reservoirs with release deficits (an in-lieu-of exchange), similar to exchanges involved in enhanced flow targets. Reduction of a given water category release is also limited by overall and category release floors, which may be the current enhanced flow target. Additionally, the reduction of releases for each water category is based on the proportion of that water category released, to the total release of all water categories available for reduction. Lastly, maximum threshold volumes must be considered for Lake Tahoe and Prosser, Stampede, and Boca Reservoirs, and a minimum threshold volume must be considered for Lake Tahoe for security of exchanged waters, and as a result, the reduction of releases may be restricted in these reservoirs. For each reservoir the following water categories are checked for reduced releases.

- Lake Tahoe-WQCW, fish credit water, nonfirm PCMICW, and pooled water.

- Donner Lake-Not applicable (no credit waters are stored in this reservoir).

- Martis Creek Lake—not applicable.

- Prosser Creek Reservoir-WQCW, fish credit water, nonfirm PCMICW, uncommitted water, natural water, and Tahoe-Prosser Exchange water.

- Independence Lake-not applicable (no credit waters are stored in this reservoir).

- Stampede Reservoir-not applicable. Water categories are first exchanged into Boca Reservoir and subsequently exchanged into Stampede Reservoir in other types of exchanges (see the later section "Voluntary Exchanges").

- Boca Reservoir-fish credit water, WQCW, nonfirm PCMICW, PCPOSW, fish water, adverseto-canal pooled water, non-adverse-to-canal pooled water, and natural water.

Fourth, release increases are determined for reservoirs that require and are capable of such releases to achieve downstream preferred flow targets. Releases for preferred flows are determined by three methods: (1) re-storage of water categories in another reservoir,
(2) exchange of water categories to another reservoir, and (3) release of JPFCW without re-storage or exchange in other reservoirs. For exchanges (item 2), potential release increases of water categories from reservoirs must be compared with potential release reductions of water categories from different reservoirs. The other two methods (items 1 and 3) do not require such comparisons.

The operations model simulates reservoir releases for preferred flow targets by the following list, which is based on the likely rank order releases for preferred flow targets (Lake Tahoe, Stampede Reservoir, Prosser Creek Reservoir, Independence Lake, and Donner Lake). At a given reservoir, if preferred flows cannot be met by exchange or re-storage in another reservoir, then JPFCW is released, if available. Unless indicated, water categories involved in release increases and decreases are those previously discussed in this section.

\section{Lake Tahoe}

In-lieu-of exchanges:

- Lake Tahoe release increase concurrent with Prosser Creek Reservoir release decrease. Water categories listed above for Lake Tahoe preferred flow release increases are exchanged with categories used to reduce Prosser Creek Reservoir releases.

-Lake Tahoe release increase concurrent with Boca Reservoir release decrease. Water categories listed above for Lake Tahoe preferred flow release increases are exchanged with categories used to reduce Boca Reservoir releases.

Release with no exchange or re-storage:

- Lake Tahoe release increase of JPFCW.

\section{Stampede Reservoir}

Re-storage:

- Stampede Reservoir release increase using water categories listed above for preferred releases, followed by re-storage in Boca Reservoir.

\section{In-lieu-of exchanges:}

- Stampede Reservoir (and corresponding Boca Reservoir) release increases concurrent with Lake Tahoe release decrease. Water cat- 
egories listed above for Stampede preferred flow releases are exchanged with categories used to reduce Tahoe releases. The increased release from Stampede is passed through Boca to meet the same demands downstream on the Truckee River as would have been satisfied by releases from Tahoe prior to an exchange.

- Stampede Reservoir (and corresponding Boca Reservoir) release increases concurrent with Prosser Creek Reservoir release decrease. Water categories listed above for Stampede preferred flow releases are exchanged with categories used to reduce Prosser releases. As described above, the increased release from Stampede is passed through Boca to meet the same demands downstream on the Truckee River as would have been satisfied by releases from Prosser prior to an exchange.

Release with no exchange or re-storage:

- Stampede Reservoir release increase of JPFCW.

\section{Prosser Creek Reservoir}

\section{In-lieu-of exchanges:}

- Prosser Creek Reservoir release increase concurrent with Lake Tahoe release decrease. Water categories listed above for Prosser Creek Reservoir preferred flow releases are exchanged with categories used to reduce Lake Tahoe releases.

- Prosser Creek Reservoir release increase concurrent with Boca Reservoir release decrease. Water categories listed above for Prosser Creek Reservoir preferred flow releases are exchanged with categories used to reduce Boca releases.

Release with no exchange or re-storage:

- Prosser Creek Reservoir release increase of JPFCW.

\section{Independence Lake}

Re-storage:
- Independence Lake release increase of PCPOSW with Stampede Reservoir re-storage.

\section{Donner Lake}

In-lieu-of exchanges:

- Donner Lake release increase concurrent with Lake Tahoe release decrease. Water categories listed above for Donner Lake preferred flow releases are exchanged with categories used to reduce Lake Tahoe releases.

- Donner Lake release increase concurrent with Prosser Creek Reservoir release decrease. Water categories listed above for Donner Lake preferred flow releases are exchanged with categories used to reduce Prosser Creek Reservoir releases.

- Donner Lake release increase concurrent with Boca Reservoir release decrease. Water categories listed above for Donner Lake preferred flow releases are exchanged with categories used to reduce Boca Reservoir releases.

Several assumptions were used in this subblock.

- Because of the large number of categories available for releases from reservoirs for preferred flow targets, a large number of voluntary exchanges are possible. The USGS Truckee River Basin operations model simulates only the most likely water categories and exchanges that would be used to attain or maintain preferred flow targets.

- Instream preferred flows are specified for several locations along the mainstem Truckee River in draft TROA. Except for the Truckee River downstream from Lake Tahoe, preferred flow targets along the mainstem Truckee River are not simulated.

- Maximum and minimum reservoir threshold volumes are simulated as constant daily values throughout a month, rather than as interpolated values between end-of-month values specified in draft TROA. The reservoir levels used for comparison with the threshold volumes are the current day's simulated volume, not a forecasted volume. Similar to exchanges involved to maintain 
enhanced flow targets, neither forecasted volumes nor seasonal foresight were used in determining the exchanges to maintain enhanced minimum-flow targets.

- Increases and reductions of reservoir releases by exchanges with another reservoir are determined by the proportion of each water category available in relation to the total volume of water categories available for the release increase or reduction, unless specified otherwise.

- Reservoirs not located on the Little Truckee River are not simulated to exchange directly into Stampede Reservoir. Such exchanges are first made directly into Boca Reservoir for later exchange into Stampede (see the section "Voluntary Exchanges").

- Water categories may change during an exchange into another reservoir. The following list illustrates those water category changes for exchanges to meet preferred flow targets.

1. Uncommitted water changes to fish credit water when exchanged from Prosser Creek Reservoir to storage in another reservoir.

2. PCPOSW changes to nonfirm PCMICW when exchanged from Donner Lake to storage in another reservoir.

\section{Enhanced Storage Security and Access}

Voluntary exchanges for enhanced storage security have the objective of relocating a specific volume and category of water from one reservoir to another reservoir that is less likely to release water due to floodcontrol criteria, or in which release amounts will not be hydraulically constrained during periods of low reservoir volumes. These are all considered voluntary exchanges, which means the transaction must be agreed to by owners of all affected water categories.

The storage characteristics of reservoirs in the Truckee River Basin can vary depending on the time of year, inflow, reservoir storage, recreational pools, and releases for downstream flows. Because of the many variables and implications to consider, draft TROA contains no criteria for voluntary exchanges to enhance the security of or access to credit water.

It will often be desirable to exchange water stored in Lake Tahoe and Prosser Creek Reservoir to Boca Reservoir. Although Tahoe is the largest reservoir in the system (usable storage 744,600 acre-ft), waters in storage may be lost or simply unavailable. First, the hydraulic capacity of the outlet diminishes as the water level approaches the natural rim $(6,223.0 \mathrm{ft}$, Lake Tahoe datum). Second, as specified in the Truckee River Agreement, the goal of Tahoe flood operations is to spill water so as to maintain the lake's water-surface at an elevation of 6,229.1 ft or less. In these two instances, the inability to access one's water or the danger of spilling water at a time when it cannot be used occasionally makes Tahoe a less desirable storage location.

Prosser Creek Reservoir has a limited storage $(29,800$ acre-ft) capacity in the spring. Later in the year, the fall precautionary drawdown may require that water be spilled to achieve a storage volume of about 9,800 acre-ft, in accordance with flood-control criteria. Because of the potential for spills, Prosser may also be a less desirable storage location.

Boca Reservoir is a better choice for storage because more storage (41,100 acre- $\mathrm{ft}$ ) is available than in Prosser Creek Reservoir. Also, an exchange to Boca is needed to move a block of water to an even safer location, Stampede Reservoir.

Stampede Reservoir is the largest reservoir in the Little Truckee River Basin (total capacity of 226,500 acre-ft), and provides much flexibility in storing water. Water is less likely to be released from this reservoir because of flood-control criteria. Waters released from Stampede are not generally constrained by outlet hydraulics and may be re-stored in Boca Reservoir. Stampede's large storage capacity and flexibility in operations means that it will normally possess more secure storage characteristics and provide better accessibility than other reservoirs. Also, because Stampede has a junior storage right to other reservoirs in the Truckee River Basin, it will be the last to fill, and thus is less likely to spill.

The USGS Truckee River Basin operations model simulates enhanced storage security exchange operations in the subblock enhanced storage security using, a simplistic approach that allows exchanges into only two reservoirs, Boca and Stampede. Simulated exchanges from Lake Tahoe or Prosser Creek Reservoir to Boca for the purpose of enhanced security are in-lieu-of exchanges. In this type of exchange, water is released from one reservoir in exchange for storage of an equal volume in another reservoir. Most of the simulated exchanges from Boca to Stampede are paper exchanges in which equal volumes are traded between 
the two reservoirs with no physical movement of water involved. Also, exchanges for enhanced storage security in the model may be turned off or on (all or none) at the option of the user.

\section{Exchanges from Lake Tahoe or Prosser Creek Reservoir to Boca Reservoir}

In the operations model, in-lieu-of exchanges are simulated from Lake Tahoe or Prosser Creek Reservoir to Boca Reservoir. The first step in simulating exchanges from Tahoe or Prosser to Boca would be to determine how much, if any, additional release from Tahoe can be made using the categories WQCW, nonfirm PCMICW, and fish credit water. Similarly, it must be determined if additional releases from Prosser can be made using the categories WQCW, nonfirm PCMICW, and fish credit water. In this first step, the previously determined releases and hydraulic capacity of the outlets are considered. The second step is to determine the amount that Boca may reduce its releases of the categories fish credit water, WQCW, nonfirm PCMICW, PCPOSW, fish water, adverse-to-canal water, non-adverse-to-canal water and natural water. The amount of reduction in releases of a given water category is based on the difference between the currently simulated release and the overall and category release floors (described in the section "Enhanced Minimum Instream Flows"). In addition to the consideration of release floors, the reduction of releases is based on the proportion of each water category released to the total release of water categories available for reduction. Finally, potential release increases from Prosser and Tahoe are compared to potential Boca release reductions using the exchange water categories listed above, if available, and the following list.

1. Prosser-Boca Exchange-If Prosser Creek Reservoir is above its prescribed threshold volume, increase releases from Prosser and reduce releases from Boca Reservoir. The prescribed threshold volumes are described in the section "Storage of Proposed Water Categories."

2. Tahoe-Boca Exchange-If Lake Tahoe is above its prescribed threshold volume, increase releases from Tahoe and reduce releases from Boca Reservoir categories.

3. Prosser-Boca Exchange-Increase releases from Prosser Creek Reservoir and reduce releases from Boca Reservoir, regardless of water levels in Prosser.

4. Tahoe-Boca Exchange-Increase releases from Lake Tahoe and reduce releases from Boca Reservoir, regardless of water levels in Tahoe.

\section{Exchanges from Boca Reservoir to Stampede Reservoir}

To enhance storage security, water is moved from Boca Reservoir to Stampede Reservoir mostly by paper exchanges. There are four likely conditions under which these exchanges are simulated and each condition, as coded in the model, is described below.

1. When the storage of pooled water in Boca Reservoir is less than 5,000 acre-ft, then exchange non-adverse-to-canal water in Stampede Reservoir to Boca. This condition is simulated when Boca is using pooled waters for Floriston rates and pooled water in Stampede is needed in Boca. Non-adverse-to-canal water can be stored in Stampede using exchanges as described in conditions (2) and (3) of Boca-Stampede Exchanges and in the sections "Enhanced Minimum Flows" and "Preferred Instream Flows." The following list shows the rank order of exchanges possible when Boca Reservoir pooled water storage is less than 5,000 acre-ft. The sources marked with an asterisk $\left(^{*}\right)$ are different from current sources.

- Paper-exchange fish water in Boca Reservoir with non-adverse-to-canal water in Stampede Reservoir.

- *Paper-exchange fish credit water in Boca Reservoir with non-adverse-to-canal water in Stampede Reservoir.

- *Paper-exchange JPFCW in Boca Reservoir with non-adverse-to-canal water in Stampede Reservoir.

- *Paper-exchange nonfirm PCMICW in Boca Reservoir with non-adverse-to-canal water in Stampede Reservoir.

- *Paper-exchange WQCW in Boca Reservoir with non-adverse-to-canal water in Stampede Reservoir.

- Exchange (by re-storage) non-adverse-tocanal water in Stampede Reservoir to Boca Reservoir. 
2. When any non-adverse-to-canal (pooled) water is remaining in Stampede Reservoir on April 1, then exchange that non-adverse-to-canal water to Boca Reservoir. Pooled water may reside in Stampede as a result of previous exchanges, such as those made to facilitate the timely release of fish water for spawning. These pooled waters should be removed from Stampede to allow for spring time filling of the reservoir with fish waters. The following list shows the rank order of the exchanges when the date is April 1 and nonadverse-to-canal water is remaining in Stampede. The sources marked with an asterisk (*) are different from current sources.

- Paper-exchange fish water in Boca Reservoir with non-adverse-to-canal water in Stampede Reservoir.

- *Paper-exchange fish credit water in Boca Reservoir with non-adverse-to-canal water in Stampede Reservoir.

- *Paper-exchange JPFCW in Boca Reservoir with non-adverse-to-canal water in Stampede Reservoir.

- *Paper-exchange nonfirm PCMICW in Boca Reservoir with non-adverse-to-canal water in Stampede Reservoir.

- *Paper-exchange WQCW in Boca Reservoir with non-adverse-to-canal water in Stampede Reservoir.

3. In the previous sections, "Pyramid Lake Fish" and "Fish Credit Water," simulated fish and fish credit waters are released from Stampede Reservoir for storage in Boca Reservoir as Boca pressure water in order to gain more timely access to these water categories when needed. To maintain the Boca pressure water storage when fish water and fish credit water storage in Boca falls below 2,000 acre-ft during a fish regime 1 from March 1 to June 5, fish water in Stampede is exchanged to Boca. In this exchange for enhanced storage security, paper exchanges are simulated between Stampede fish water and fish credit water and four categories of Boca waters. The following list shows the ranked order of the exchanges simulated under these conditions. Again, the sources marked with an asterisk (*) are different from current sources.
- *Paper-exchange non-adverse-to-canal water in Boca Reservoir with fish credit water in Stampede Reservoir.

- *Paper-exchange adverse-to-canal water in Boca Reservoir with fish credit water in Stampede Reservoir.

- *Paper-exchange JPFCW in Boca Reservoir with fish credit water in Stampede Reservoir.

- *Paper-exchange nonfirm PCMICW in Boca Reservoir with fish credit water in Stampede Reservoir.

- Paper-exchange non-adverse-to-canal water in Boca Reservoir with fish water in Stampede Reservoir.

- Paper-exchange adverse-to-canal water in Boca Reservoir with fish water in Stampede Reservoir.

- *Paper-exchange JPFCW in Boca Reservoir with fish water in Stampede Reservoir.

- *Paper-exchange nonfirm PCMICW in Boca Reservoir with fish water in Stampede Reservoir.

4. As described in the previous section "WaterQuality Targets and Related Instream Flow Transfers," Boca Reservoir will be used for temporary storage of WQCW for quick release to the Truckee River. This type of re-regulation will facilitate timely access to WQCW when needed. To maintain this temporary storage of WQCW, when the WQCW in Boca falls below 300 acre- $\mathrm{ft}$ between June 1 and September 30, and Stampede Reservoir WQCW releases, as determined in the previous section, are not enough to create 300 acre-ft of WQCW storage in Boca, then WQCW is exchanged in Stampede to Boca. In this enhanced storage-security exchange, paper exchanges are simulated between Stampede WQCW and five categories of Boca waters as follows in ranked order.

- Paper-exchange non-adverse-to-canal water in Boca Reservoir with WQCW in Stampede Reservoir.

- Paper-exchange fish water in Boca Reservoir with WQCW in Stampede Reservoir. 
- Paper-exchange fish credit water in Boca Reservoir with WQCW in Stampede Reservoir.

- Paper-exchange JPFCW in Boca Reservoir with WQCW in Stampede Reservoir.

- Paper-exchange nonfirm PCMICW in Boca Reservoir with WQCW in Stampede Reservoir.

This subblock includes the following assumptions.

- Although a large number of categories and voluntary exchanges are possible, the operations model only simulates the most likely exchanges for enhanced security. Exchanges for this purpose are only simulated from Lake Tahoe and Prosser Creek Reservoir to Boca Reservoir, and from Boca Reservoir to Stampede Reservoir. Donner and Independence Lakes are not included in these exchanges for enhanced storage. Additional exchanges, and the order in which the exchanges are considered, can be implemented by modifying the code in the operations model, but only by experienced programmers.

- Exchanges as described in the section "Current Operational Exchanges," such as the TahoeProsser and Donner-Boca Exchanges, will occur prior to the exchanges described in this section.

- An exchange for enhanced security is not simulated if the reservoir receiving the water is above the maximum prescribed threshold volume. Water will not be exchanged out of Prosser Creek Reservoir if the uncommitted water volume falls below 9,800 acre-ft. This constraint on exchanges is assumed to allow enough uncommitted water in Prosser for the Tahoe-Prosser Exchange (Thomas R. Scott, Bureau of Reclamation, oral commun., 1997). The reservoir levels used for comparison with the prescribed threshold volumes in the conditional logic for enhanced storage security are the current day's simulated volume, not a forecasted volume. Neither forecasted volumes nor foresight was used in determining the exchanges for enhanced security.

- JPFCW is not considered in exchanges of credit waters from Lake Tahoe or Prosser Creek Reservoir to Boca Reservoir because there are no guidelines to determine what reservoir is strategically superior for storage of JPFCW.

- In the operations for enhanced storage security, pooled water can be exchanged into Stampede Reservoir. The only pooled water stored in Stampede in the model is non-adverse-to-canal water. This assumption was necessary to minimize the number of pooled water categories in Stampede.

\section{Efficient Use of Releases for Precautionary Drawdowns}

Under flood-control criteria, it is sometimes necessary to release water from a reservoir as a precautionary drawdown. Voluntary exchanges under draft TROA will allow precautionary drawdown releases to meet several objectives. In addition to the DonnerBoca Exchange described in the section "Current Operational Exchanges," the three most likely exchanges for efficient use of releases for precautionary drawdowns to be practiced are a Donner-Tahoe Exchange, a Prosser-Tahoe Exchange, and a Prosser-Boca Exchange. These three exchanges would be informal agreements that specify that waters required to be released for flood control due to precautionary drawdown may be exchanged to pooled water for maintenance of Floriston rates.

In these in-lieu-of exchanges, water released from one reservoir for precautionary drawdown is exchanged to pooled water for maintenance of Floriston rates. In exchange, an equivalent volume of pooled water that was being released from the reservoir contributing to Floriston rates will be reduced. The volume stored as a result of the reduction in releases is then exchanged to the category that had to be released for precautionary drawdown. Thus, depending on the volumes of water exchanged, all or some releases of pooled water for maintenance of Floriston rates will be made from other reservoirs. In effect, these exchanges allow the releases required from precautionary drawdowns to meet three objectives instead of one: (1) precautionary drawdown to the wintertime cap for creation of flood-control space, (2) maintenance of Floriston rates, and (3) storage of nonpooled waters in other reservoirs for later use rather than release downstream.

The USGS Truckee River Basin operations model simulates exchanges for efficient use of water associated with precautionary drawdowns in the subblock efficient use of releases. The three in-lieu-of exchanges are similar to the Donner-Boca Exchange, 
described in the section "Current Operational Exchanges." These exchanges are simulated during precautionary drawdown periods for Donner Lake and Prosser Creek Reservoir. The following list describes the exchanges coded in the operations model.

- Donner-Tahoe Exchange-From August 15 to November 15, exchange PCPOSW released as precautionary drawdown from Donner Lake with pooled water in Lake Tahoe being released. The PCPOSW exchanged into Tahoe becomes nonfirm PCMICW.

- Prosser-Tahoe Exchange-From October 1 to 31 , exchange uncommitted water released as precautionary drawdown from Prosser Creek Reservoir with pooled water in Lake Tahoe being released. The uncommitted water exchanged into Tahoe becomes fish credit water.

- Prosser-Boca Exchange-From October 1 to 31, exchange uncommitted water released as precautionary drawdown from Prosser Creek Reservoir with adverse-to-canal water in Boca Reservoir being released. The uncommitted water exchanged into Boca becomes fish credit water.

Assumptions in this subblock include the following items.

- An exchange made to efficiently use precautionary drawdowns for release will not be simulated if the receiving reservoir is above the prescribed threshold volume.

- A tolerance of $3.0 \mathrm{ft}^{3} / \mathrm{s}$ of reservoir releases due to precautionary drawdown is used to determine when these exchanges can be simulated. If releases are less than $3.0 \mathrm{ft}^{3} / \mathrm{s}$, no exchange will be simulated. This tolerance may be modified by the user.

- Under draft TROA, the exchanges described in this section for efficient use of releases for precautionary drawdowns are simulated whenever possible. The user does not have the option to prevent these exchanges from being simulated.

- There is a difference between the Prosser-Boca Exchanges described in this section and in the section "Enhanced Storage Security and Access." The exchange described in this section can only be simulated between October 1 and April 9 during precautionary drawdowns and between uncommitted water and adverse-to-canal water. The exchanges described in the other section can be simulated anytime between several categories, but exchanges are not simulated with uncommitted water.

- Although a large number of categories and voluntary exchanges are possible for the efficient use of releases for precautionary drawdowns, the operations model only simulates the listed exchanges.

- Draft TROA credit water categories were not considered for the efficient use of releases for precautionary drawdowns exchanges. As described in the section "Merge Reservoir Releases for Multiple Objectives," under "Proposed Reservoir Operations," in most situations credit water categories will be displaced before current water categories. However, it has been assumed in the operations model that current water categories will provide a better opportunity for the water not to be displaced.

\section{Maintenance of Recreational Pools}

One of the multiple-use benefits of reservoirs is to maintain storage levels that enhance boating, fishing, and other summer recreational uses. These storage levels that promote public use of the reservoirs are called recreational pools. Different types of reservoir releases or exchanges may cause reservoir levels to be above or below recreational pools. When possible, reservoir releases or exchanges can be operated to maintain a recreational pool.

Under current operations, the only reservoir that has a legal recreational pool is Donner Lake (stage of $5,932.0 \mathrm{ft}$ or storage of 6,310 acre-ft), as defined in the Donner Lake Indenture of 1943. Prosser Creek Reservoir is informally operated by adjustment of reservoir releases with consideration of a recreational pool of 19,000 acre-ft, as described in the section "Floriston Rates." Independence Lake is informally operated with consideration of minimum pool volume of 10,000 acre$\mathrm{ft}$ to benefit Lahontan cutthroat trout spawning upstream from the lake (Richard D. Moser, Sierra Pacific Power Company, written commun., 1995). No formal exchanges for maintenance of recreational pools are used in current operations.

Under draft TROA, California would recommend minimum recreational pools for reservoirs that would apply from about June through Labor Day. Water would be voluntarily exchanged among the reservoirs 
to achieve the objectives, but would not interfere with downstream demands, mandatory exchanges, or any current legal agreements or decrees. Also under draft TROA, JPFCW may be used in voluntary exchanges to meet recreational pool objectives. Minimum recreational pool levels for Truckee River Basin reservoirs have been defined as follows (Kathleen Egan, City of Truckee, written commun., 1997).

- Donner Lake-8,800 acre-ft.

- Prosser Creek Reservoir-19,000 acre-ft.

- Boca Reservoir-33,500 acre-ft.

- Stampede Reservoir-127,000 acre-ft.

- Independence Lake-10,000 acre-ft.

- Lake Tahoe and Martis Creek Lake-no defined recreational pool volumes.

The USGS Truckee River Basin operations model simulates maintenance of recreational pools in the subblock maintenance of recreational pools as follows. Operations considering recreational pools for Donner and Independence Lakes and Prosser Creek Reservoir are simulated in several subblocks and the user does not have the option to turn these operations on or off. Therefore, although recreational pool objectives are set for Donner Lake and Independence Lakes and Prosser and Boca Reservoirs, voluntary exchanges are only simulated to maintain Boca Reservoir recreational pool objectives. All draft TROA exchanges for enhancement of the recreational pool objectives for Boca may be turned off or on at the option of the user. The operations model does not simulate exchanges to meet recreational pool levels for Martis Creek Lake and Lake Tahoe. It is assumed that the high storage needed for recreational pools in Stampede could only be met in years in which runoff is above average. It would be difficult to implement the number and magnitude of the exchanges necessary to satisfy the recreational pool level in a dry year.

Next, as in actual operations, the model can manage various types of releases to maintain recreational pools. These simulated releases for each reservoir are described in various subblocks of the model. The following list describes the operations in various subblocks where recreational pool maintenance is considered for Donner and Independence Lakes and Prosser and Boca Reservoirs. These releases are simulated under both current operations and draft TROA.
- Donner Lake-A recreational pool was first specified in the Donner Lake Indenture of 1943 to be held above 5,932.0 ft and below 5,935.8 ft for the months of June through August. In the operations model, there is no specific subblock to maintain recreational pools for the lake. However, in some subblocks that determine the releases from the lake, the recreational pool of $5,932 \mathrm{ft}$ or 6,310 acre- $\mathrm{ft}$ is considered. For example, in the section "Privately Owned Stored Water," Donner Lake elevation is held above 5,932 ft for the period June 16 to September 1. (See also the other sections "Storage Priorities," "Reservoir PassThroughs and Releases to Meet Newlands Project Demands," and "Minimum Instream Flows.")

- Independence Lake-Recreational pools of 10,000 and 7,500 acre-ft have been coded for current operations and draft TROA, respectively. There is no specific subblock for maintenance of recreational pools for Independence Lake. However, in other subblocks that determine the releases from the lake, the recreational pool is considered. (See section "Privately Owned Stored Water" in the section "Current Reservoir Operations.") For example, when Independence releases are needed to fill Boca Reservoir PCPOSW to 800 acre-ft, and if lake levels are below the recreational pool of 10,000 acre-ft, no releases will be made. The Independence Lake recreation pool of 7,500 acre- $\mathrm{ft}$ is also included in the section "Privately Owned Stored Water" in the section "Current Reservoir Operations," and in sections "Power Company M\&I Credit Water" and "Mandatory Exchanges and Transfers" of the "Proposed Reservoir Operations" section.

- Prosser Creek Reservoir-There is no specific subblock for maintenance of recreational pool for Prosser Creek Reservoir. However, in two subblocks that determine the releases from the reservoir, the recreational pool is considered. For example Prosser recreational pool is considered in the section "Floriston Rates." When Prosser releases are needed to satisfy Floriston rates demands, and if reservoir levels are below the minimum recreational pool of 19,000 acre-ft, no releases will be made unless there are no alternative sources. (See also the section "Water-Quality Targets and Related Instream Flow Transfers.") 
- Boca Reservoir-In the subblock maintenance of recreational pools, exchanges for recreational pools are simulated. In the operations model, exchanges from Lake Tahoe or Prosser Creek Reservoir to Boca for the purpose of maintenance of recreational pools are in-lieu-of exchanges. In these exchanges, releases from Boca are decreased with the objective of maintaining water levels for a recreational pool. The volume that would have been released from Boca will instead be released from Lake Tahoe or Prosser Creek Reservoir. Under the following conditions, inlieu-of exchanges are simulated.

1. Date is between May 1 and August 30 (recreational season), and

2. It is a normal season, as defined in the section "Normal and Dry Season," and

3. Boca Reservoir storage must be no more than 4,000 acre- $\mathrm{ft}$ above the recreational pool of 33,500 acre-ft. If the Boca storage is greater than 37,500 acre-ft, then no exchanges for recreational pools will occur. This 4,000 acre-ft provides a volume range above the recreational pool level, but below the flood-control criteria volume, where the recreational pool exchanges are likely to occur.

The first step in simulating in-lieu-of exchanges from Lake Tahoe or Prosser Creek Reservoir to Boca Reservoir is to determine how much, if any, additional release from Tahoe can be made using the categories pooled water and JPFCW. Similarly, it must be determined if additional releases from Prosser can be made using the categories TPEW and JPFCW. The previously determined releases and hydraulic capacity of the outlet are also considered. The second step is to determine the amount that Boca Reservoir may reduce its releases of the categories adverse-to-canal and nonadverse-to-canal water, JPFCW, fish credit water, WQCW, nonfirm PCMICW, PCPOSW, and fish water. The amount of reduction in releases of a given water category is based on the difference between the currently simulated release and the overall and category release floors (described in the section "Enhanced Minimum Instream Flows"). In addition to the consideration of release floors, the reduction of releases is based on the proportion of each water category released to the total release of water categories available for reduction. Finally, potential release increases from Prosser Creek Reservoir and Lake Tahoe are compared to potential Boca Reservoir release reductions using the exchange water categories listed above, if available, and the following list.

1. Prosser-Boca Exchange-The increased release of water categories from Prosser Creek Reservoir are exchanged with a reduced release of water categories from Boca Reservoir.

2. Tahoe-Boca Exchange-The increased release of water categories from Lake Tahoe are exchanged with a reduced release of water categories from Boca Reservoir.

Assumptions in this subblock for maintenance of recreational pools in Boca Reservoir include the following items.

- Although other categories and voluntary exchanges are possible for maintaining recreational pools, the operations model simulates only the listed exchanges with the stated categories.

- Forecasting reservoir levels could provide a more realistic probability of maintaining recreational pools from May 1 to August 30. However, only current reservoir levels are used in the model to determine exchanges for maintenance of recreational pools.

- An exchange for maintenance of recreational pools is not simulated if the receiving reservoir (Boca Reservoir) is above the prescribed threshold volume.

\section{Merge Reservoir Releases for Multiple Objectives}

Similar to existing operations as described under this title in the section "Description and Simulation of Current Operations," water released from a given reservoir under draft TROA may serve a variety of objectives. Releases may consist of specified (tagged) water categories or untagged waters that consist of any water category. Typically, releases made to satisfy specific downstream demands are tagged to specific water categories. Untagged releases result from spills (including both uncontrolled spills over reservoir spillways and precautionary drawdowns based on flood-control criteria) or maintenance of minimum flows. 
A draft TROA article entitled "Operations" addresses the order of water categories for mandatory untagged releases based on flood-control criteria from Truckee River reservoirs (Bureau of Reclamation and others, 1998). Under these proposed operations, the order of water categories assigned to untagged releases may change depending on whether or not a drought situation exists (see subsequent section "Drought Situation"). The categories of water described in the Operations article are pooled water (including adverseand non-adverse-to-canal water), Tahoe-Prosser Exchange water, fish water, privately owned stored water (POSW), uncommitted water, fish credit water, Joint Program fish credit water (JPFCW), firm Power Company M\&I credit water (firm PCMICW), nonfirm Power Company M\&I credit water (nonfirm PCMICW), California M\&I credit water (CMICW), water-quality credit water (WQCW), Fernley credit water, Newlands Project credit water, irrigation credit water, and other credit water.

The operations model simulates merged reservoir releases for multiple objectives in the subblock $\boldsymbol{m e r g e}$. As discussed earlier in the current operations section, if tagged releases are greater than untagged releases from a reservoir, then the mandatory untagged releases are satisfied by the water categories already proposed for release. However, if the untagged releases are greater than the tagged releases, then the difference between the untagged and tagged releases must be computed, and it is this difference that represents that volume of the mandatory untagged releases that must be assigned to water categories. Table 9 lists the rank-order scheme of water categories assigned to untagged releases for proposed operations from each reservoir. Note that table 9 lists water categories used for both current and proposed operations. The categories of water utilized for merged reservoir releases in the model are natural water, pooled water, fish water, PCPOSW, TCIDPOSW, uncommitted water, fish credit water, Joint Program fish credit water (JPFCW), firm PCMICW, nonfirm PCMICW, CMICW, and WQCW. The water categories Fernley credit water, Newlands Project credit water, irrigation credit water, and other credit water are not simulated by the operations model, as discussed in the section "Storage of Proposed Water Categories."

Under draft TROA and WQSA, the presence of a drought situation may change the order of water categories assigned to untagged releases. Additionally, the rank-order scheme of water category assignments to untagged releases may change for different types of releases (flood-control and minimum flow) as illustrated in table 9 .

Unlike current operations, under draft TROA and WQSA, inflow water categories may force releases of other water categories in reservoir storage when mandatory untagged releases are required, such as a precautionary drawdown or uncontrolled spill. These forced releases, called displacements, depend on the rankorder scheme of a reservoir (table 9). Thus, inflow of a given water category will displace water categories of lower rank. Typically, draft TROA credit water categories are of lower rank than the unregulated inflow categories: pooled water for Lake Tahoe and natural water for other reservoirs. Exceptions are firm PCMICW and Power Company emergency drought supply (PCEDS) in Stampede Reservoir, which cannot be displaced. Except for Lake Tahoe, where pooled water inflow to the lake remains as pooled water when stored, natural water inflows will convert to the assigned project waters of a given reservoir once stored. Thus, mandatory untagged releases serve to displace many draft TROA credit water categories by the creation of project waters. Regulated inflows released from upstream reservoirs may also displace water categories of lower rank during mandatory untagged releases. Thus, during a drought situation, reservoir inflow of nonfirm PCMICW released from Stampede may displace fish credit water and JPFCW in Boca Reservoir (table 9).

The following assumptions were used in the model code development for simulating the merged releases for proposed operations from reservoirs.

- Although draft TROA article "Operations" addresses the order of water categories assigned to such untagged releases as spills and displacements, a slightly different rank order of water categories for untagged releases is assumed for simulations. The order, shown in table 9, may be modified by the model user.

- Natural water is simulated as the unregulated inflow category for all reservoirs except Lake Tahoe. For Tahoe, pooled water is simulated as the inflow category. For Stampede and Boca Reservoirs, in addition to inflows of natural water from unregulated subbasins and pass-throughs from upstream reservoirs, inflow categories consist of other water categories released from upstream reservoirs. 
Table 9. Rank order of water categories assigned to untagged releases under Truckee River Operating Agreement and Water Quality Settlement Agreement

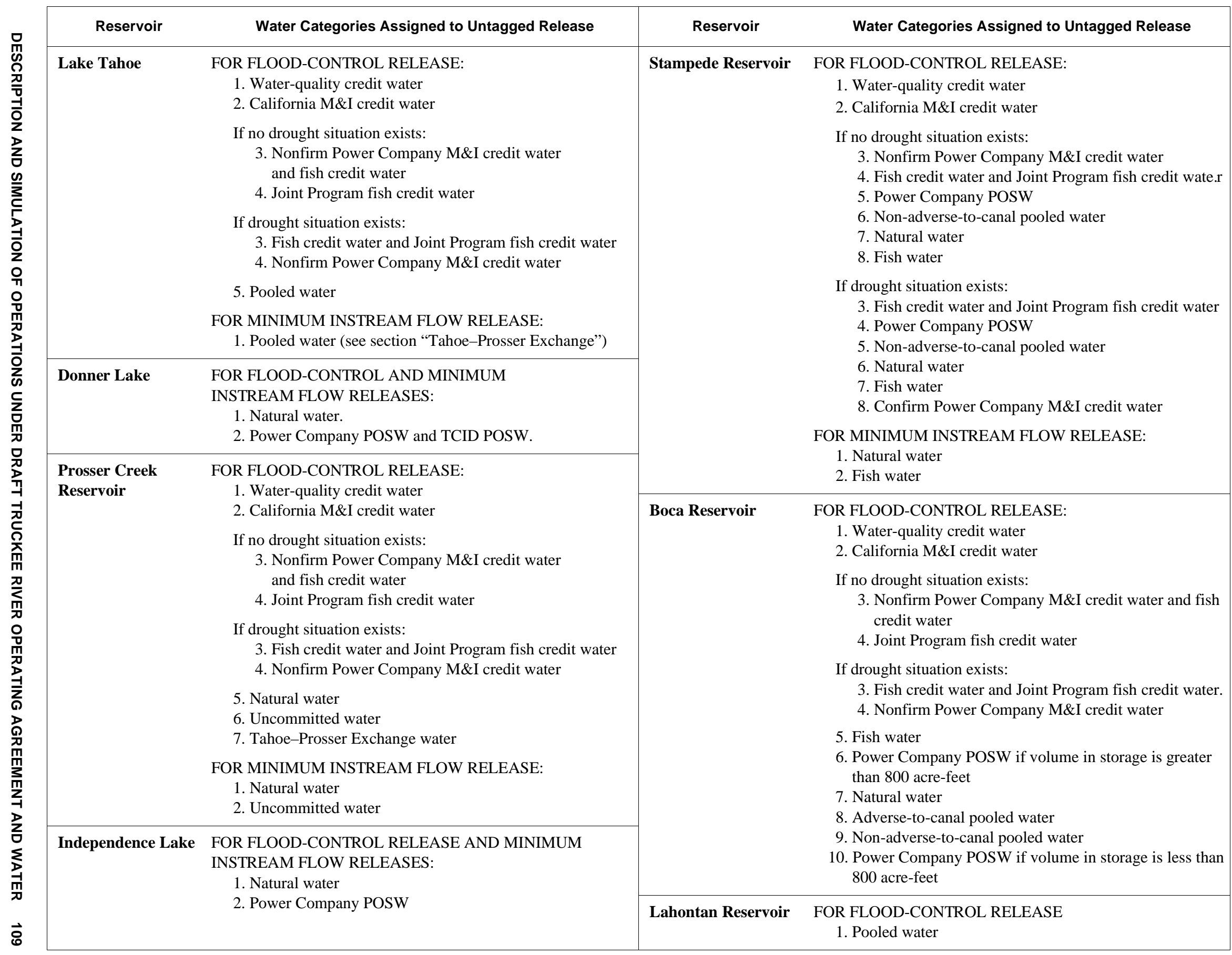


- All Martis Creek Lake releases are simulated in the subblock flood-control criteria, because this reservoir is operated for flood control. See the previous section "Flood Control-Criteria," for a description of Martis Creek Lake operations. Storage in and releases from this reservoir consist only of natural water for simulations under proposed operations.

\section{Losses and Gains to Reaches}

Under draft TROA and WQSA operations, evaporation, precipitation, and inflows create losses or gains to reaches that modify accounts of water categories. Draft TROA provides guidelines for the adjustment of reservoir storage accounts of water categories from daily net evaporation. Daily net evaporation is calculated as the evaporation rate minus the precipitation applied to the surface area of a reservoir for a given day. When precipitation and inflows exceed evaporation, usually from November or December through May or June, reservoir storage will increase, and that increase is considered as a positive reservoir inflow of pooled water for Lake Tahoe or natural water for the other lakes and reservoirs. When evaporation exceeds precipitation and inflows, reservoir storage will decrease, and that decrease is considered as a loss assigned to water categories based on a rank-order scheme described as follows.

\section{Lake Tahoe}

Part of the net evaporation will be assigned to water categories in storage other than pooled water. That part of net evaporation will be determined by applying to the net evaporation a proportion relating the increase in lake surface area attributed to the volume of only these categories to the total lake surface area. The remaining part of net evaporation is assigned to pooled water.

\section{Donner Lake}

Net evaporation will be allocated first to daily Donner Lake inflow, and then to categories in storage other than Power Company POSW (PCPOSW) and (TCIDPOSW). The net evaporation will be determined by applying to the remaining net evaporation a proportion relating the increase in lake surface area attributed to the volume of these categories to the total lake surface area. The remaining part of net evaporation is assigned to PCPOSW and TCIDPOSW waters.

\section{Martis Creek Lake}

Net evaporation will be allocated to all water categories in storage in proportion to the volumes of the water categories.

\section{Prosser Creek Reservoir}

Net evaporation will be first allocated to all water categories in storage except Tahoe-Prosser Exchange water and dead and inactive storage in proportion to the volumes of the water categories. Then the remaining part of net evaporation will be assigned first to Tahoe-Prosser Exchange water (TPEW) and second to dead and inactive storage.

\section{Independence Lake}

Net evaporation will be allocated first to daily Independence Lake inflow and then to categories in storage other than PCPOSW. The net evaporation will be determined by applying to the remaining net evaporation a proportion relating the increase in lake surface area attributed to the volume of these categories to the total lake surface area. The remaining part of net evaporation is assigned to PCPOSW water.

\section{Stampede Reservoir}

Net evaporation will be allocated first to all water categories in storage except Power Company emergency drought supply (PCEDS), firm PCMICW, TPEW, and dead and inactive storage in proportion to the volumes of the water categories, and then to the following categories by priority order: firm PCMICW, PCEDS, TPEW, and last to dead and inactive storage.

\section{Boca Reservoir}

Net evaporation will be allocated to all water categories in storage in proportion to their volumes.

Draft TROA also provides guidelines for the adjustment of storage accounts of water categories of river reaches. Flow in the Truckee River and its tributaries may increase or decrease as water moves through river reaches downstream. All increases in flow will be allocated to natural water. Decreases are called conveyance losses and will be proportionately allocated to the flow of all water categories except privately owned stored water

The following discussion describes the simulation of evaporation, precipitation, and inflow losses and gains from reservoir and river reaches in the USGS 
Truckee River Basin operations model: first, the methods to simulate gains and losses and then the selection of water-category accounts for gains and losses.

Depending on the external time series input for reservoir and river reaches, either net inflow or separate evaporation and precipitation fluxes may be simulated (see previous section, "Data for Simulation of Streamflow and Operations"). As described under this title in the section "Description and Simulation of Current Operations," evaporation and precipitation fluxes or net inflow to and from reservoir and river reaches is simulated in the RCHRES block.

For Truckee River reservoirs (except Lake Tahoe), for Pyramid Lake, and for river reaches downstream from Vista, external time series of evaporation and precipitation depths are input to the simulation model. For Lake Tahoe and river reaches upstream from Vista, external time series of net inflows are input to the simulation model. Although net evaporation may not be simulated for reservoir reaches as described in draft TROA, the simulation of net inflows or separate evaporation and precipitation fluxes results in the same objective as simulation of net evaporation: determination of net gains or losses to the given reservoir reach. For Lahontan Reservoir, losses are simulated as described in the previous section "Truckee River Diversions to Newlands Project." For a more detailed discussion of the methods used to construct the external time series, see the previous sections "Data for Simulation of Streamflow" and "Operations and Losses and Gains to Reaches" under "Current Operations."

Storage accounts of water categories must be adjusted for changes in storage resulting from losses and gains to reaches. As for simulation of current operations, inflow under draft TROA, including unregulated tributary inflow and precipitation, is assigned to pooled water for Lake Tahoe and to natural water for the other lakes and reservoirs. For river reaches, inflow, including unregulated tributary inflow and precipitation, is assigned to natural water from Lake Tahoe to the Farad gaging station (reaches 100 through 240). Downstream from the Farad gaging station (reaches 250 through 580), all inflows from tributaries and precipitation are assigned to pooled water.

Conveyance losses from river reaches are simulated using evaporation and ET from phreatophytes. Downstream from the Vista gaging station, these losses are assigned to pooled water (Berris, 1996), and upstream from the Vista gaging station, they are implicit in the methods used to determine net inflows from tributaries. Because the net inflows to reaches from Lake Tahoe to the Farad gaging station are positive, losses between Tahoe and Farad are not assigned to water categories. Losses between Farad and Vista are assigned first to pooled water, second to fish water, and last to WQCW.

Simulated reservoir losses from evaporation or negative net inflows are assigned to categories by rank order. If more than one category shares the same priority, then losses are assigned to those categories in proportion to their volumes. The following are the water category assignments to reservoir losses from evaporation or negative net inflows in the operations model.

\section{Lake Tahoe}

Net losses will be allocated to pooled water.

\section{Donner Lake}

Evaporation will be allocated first to Donner Lake inflows. The remaining part of evaporation will then be assigned equally to PCPOSW and TCIDPOSW.

\section{Martis Creek Lake}

All evaporation will be assigned to natural water.

\section{Prosser Creek Reservoir}

Evaporation is allocated first to all water categories in storage except Tahoe-Prosser Exchange water (TPEW) in proportion to the volumes of the water categories. After applying evaporation to the water categories as described above, the remaining part of evaporation is allocated to TPEW.

\section{Independence Lake}

Evaporation is allocated first to Independence Lake inflows. The remaining part of evaporation is allocated to PCPOSW.

\section{Stampede Reservoir}

Evaporation is allocated first to all water categories in storage except firm PCMICW and PCEDS in proportion to their volumes. The remaining part of evaporation is allocated first to firm PCMICW and second to PCEDS water.

\section{Boca Reservoir}

Evaporation will be allocated to all water categories in storage in proportion to their volumes.

\section{Pyramid Lake}

Evaporation will be allocated to pooled water. 
Several assumptions were made in developing the code simulating losses and gains from evaporation and precipitation. Some of the more notable assumptions follow.

- Water categories other than natural water, PCPOSW, and TCIDPOSW are not assigned to evaporation for Donner Lake simulations. Water categories other than natural water and PCPOSW are not assigned to evaporation for Independence Lake simulation.

- Net losses for Lake Tahoe are not applied to the increased surface area attributed to the volumes of specified categories other than pooled water. For the lake, net losses will be applied only to pooled water. This assumption is not expected to create largely different results because increased surface areas attributed to the draft TROA categories typically will be small compared to the surface areas related to the volume of pooled water.

- Evaporation is assigned only to natural water for Martis Creek Lake simulation.

- For Prosser Creek and Stampede Reservoirs, volumes of dead and inactive storage are not simulated as water categories. Instead, evaporation is assigned to other categories in the order specified above.

- In the simulation model, Stampede Reservoir will not contain Tahoe-Prosser Exchange water. Therefore, evaporation is not assigned to TahoeProsser Exchange water.

\section{Forecasts Affecting Operational Decisions}

This section describes three runoff and reservoir storage forecasts used to guide the simulation of operations. Under draft TROA, two of the forecasts are a determination of (1) a normal or dry season, and (2) a drought situation, and the third is the "runoff index". Although not specified in the draft TROA, the runoff index is used in the operations model for several logical decisions that require judgement or a need for qualitatively categorizing an upcoming runoff season.

\section{Normal and Dry Season}

In article nine of the draft TROA, Beneficial Uses of Water in California for Instream Flows and Recreation, (Bureau of Reclamation and others, 1998), proposed criteria are specified for the release of water from reservoirs to maintain instream flows for fish and biological resources. Instream flows and enhanced minimum instream flows for reservoirs are specified on the basis of whether the season is normal or dry, as determined by certain reservoir releases, storage and forecasted runoff. In general, the determination of normal or dry season depends upon the amount of pooled water stored in Lake Tahoe and the current forecast of Truckee River Basin natural flow in the Truckee River at the California-Nevada State line. The determination of a normal or dry season is made on each day from February through June using graphs from draft TROA shown in figures 5 and 6 . A separate determination is specified for days in July through January. Separate designations will be made for the Lake Tahoe Basin and for the Truckee River Basin.

The USGS Truckee River Basin operations model simulates determination of normal or dry season in the subblock initial numerical assignments and computations as follows.

- For the months of February through June, the simulated current Lake Tahoe pooled water volume and the current NRCS forecast of April-July Truckee River Basin runoff at Farad are used to determine a normal or dry season on the basis of the graphs on figures 5 and 6 , which are taken from the draft TROA.

- For the month of October, the designation is the same as that computed for September except if pooled water stored in Lake Tahoe is less than specified volumes. For Lake Tahoe, the season will be designated as a dry season if the volume of pooled water stored in Lake Tahoe is less than 150,000 acre-ft. For Donner Lake, Prosser Creek Reservoir, Independence Reservoir, Stampede Reservoir, and Boca Reservoir, the season will be designated as a dry season if the volume of pooled water stored in Lake Tahoe is less than 50,000 acre-ft.

- For the months of July through September, the designation is the same as that computed for June. For the months of November through January, the designation is the same as that computed for October.

The following assumption was used in the model code development for determination of normal and dry season. 


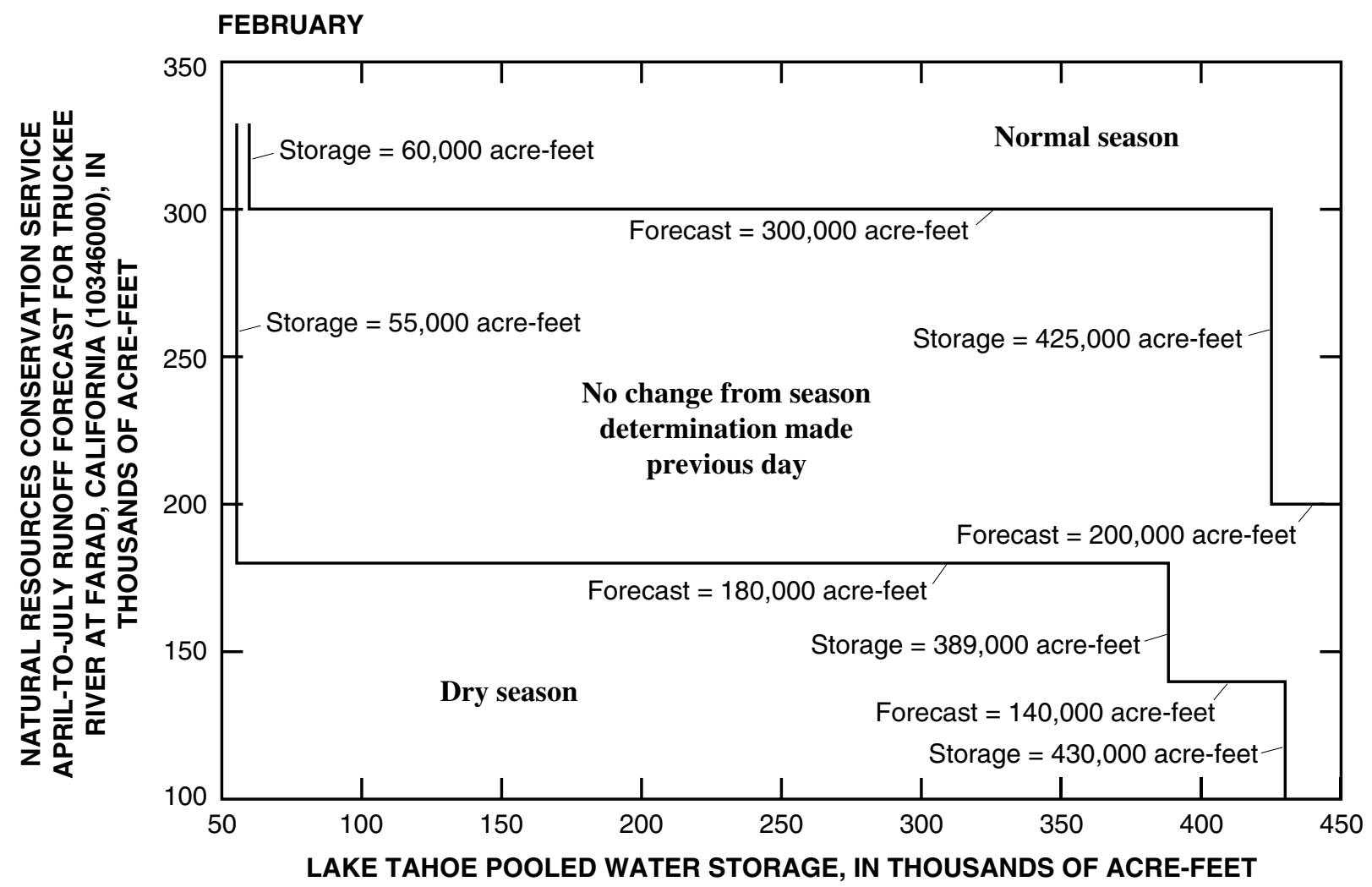

MARCH

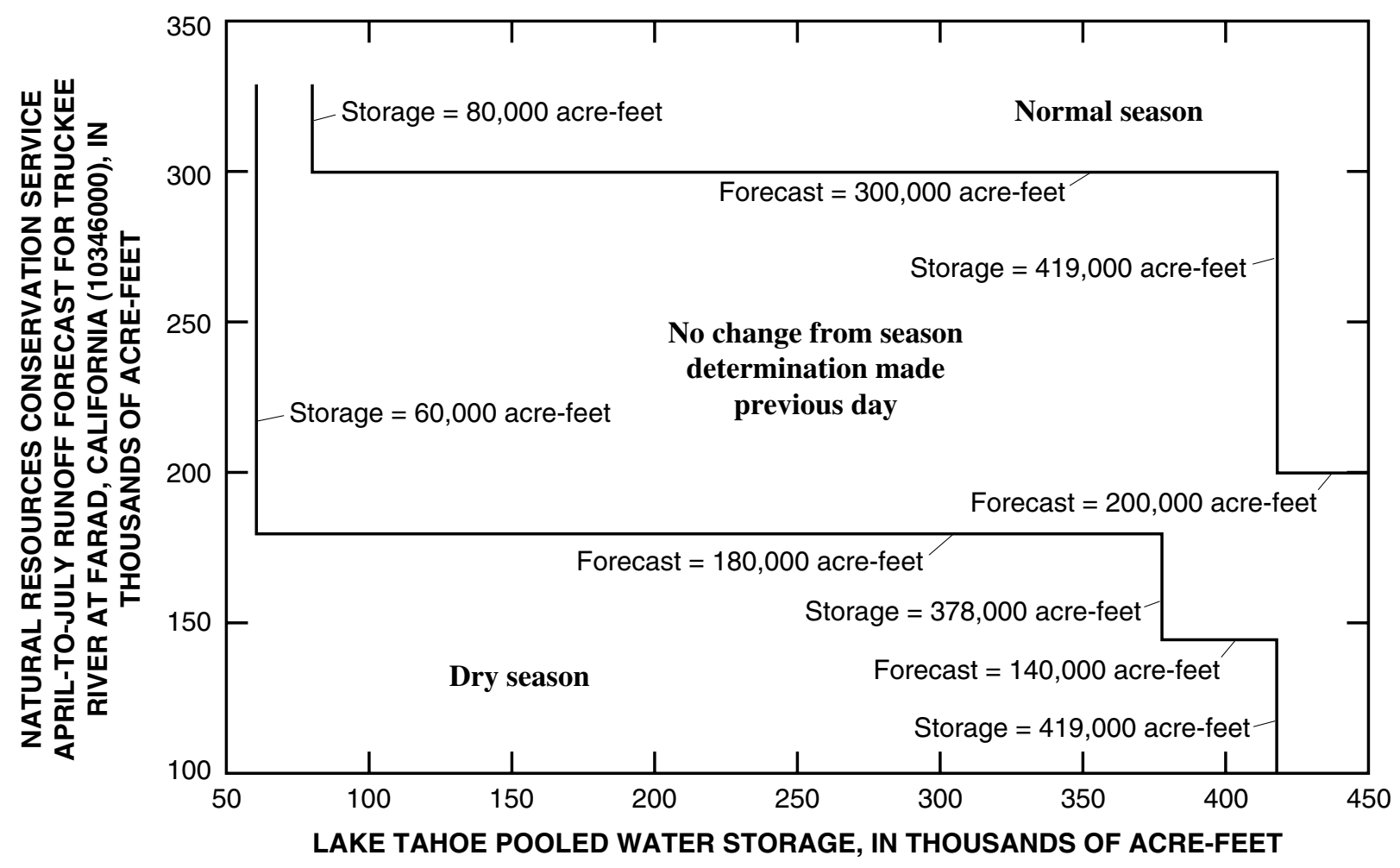

Figure 5. Determination of normal or dry seasons for Lake Tahoe, February-June 
APRIL

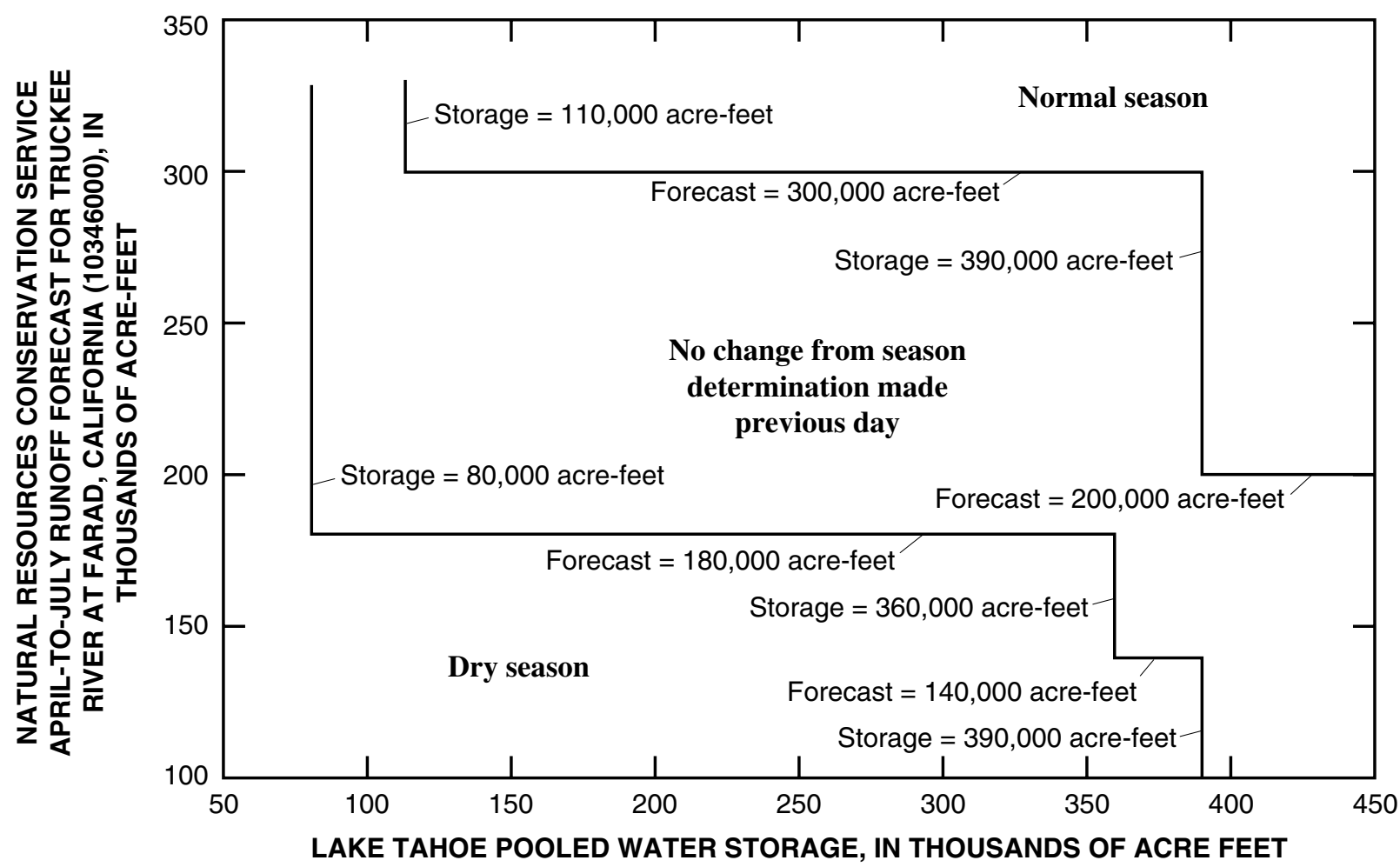

MAY

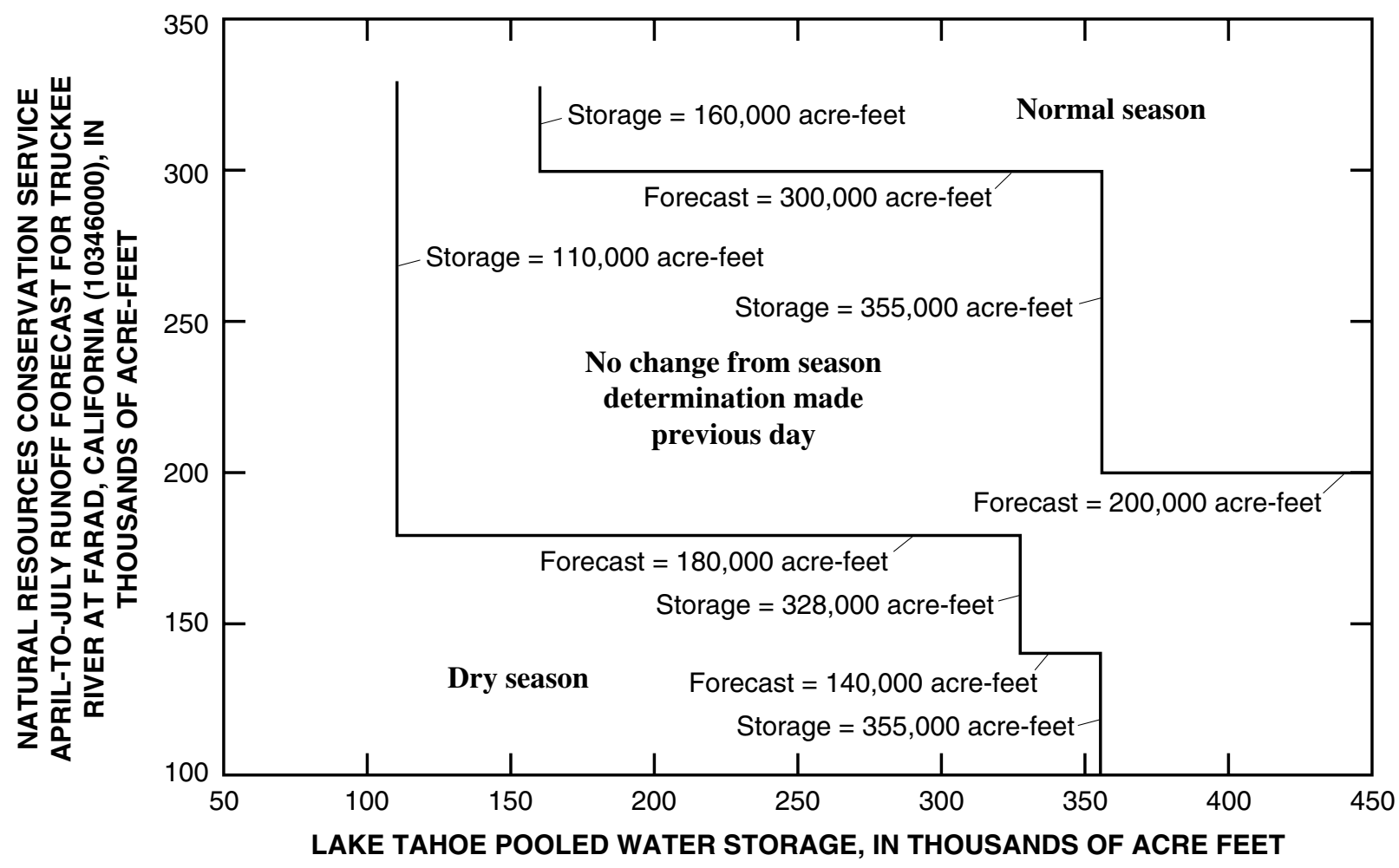

Figure 5. Determination of normal or dry seasons for Lake Tahoe, February-June-Continued 


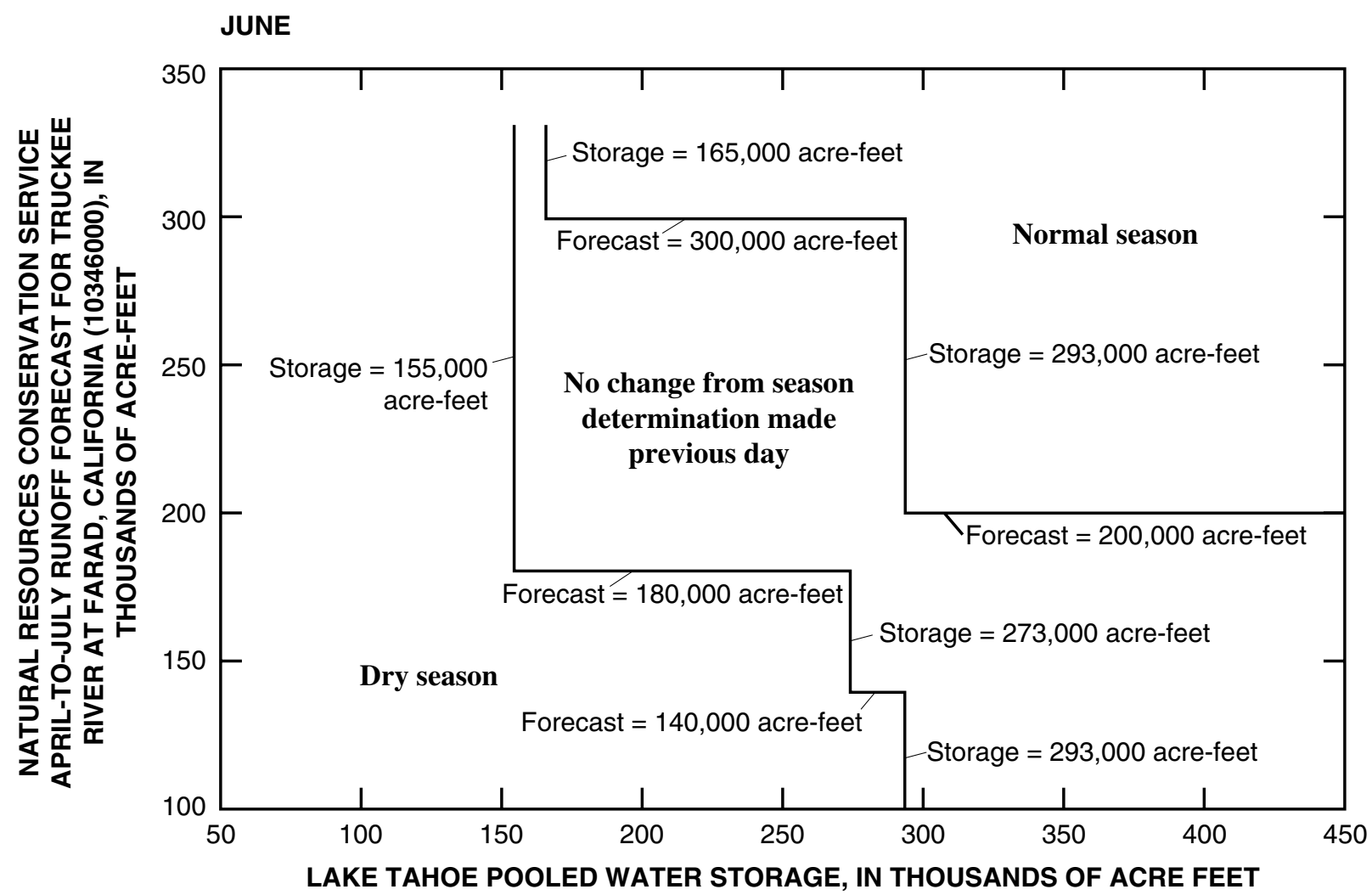

Figure 5. Determination of normal or dry seasons for Lake Tahoe, February-June-Continued

- If the designation computed in the subblock falls in between the dry and normal year, (shown as "NO CHANGE" in figures 5 and 6), then no change in the normal or dry year designation will be computed.

\section{Drought Situations}

As used in the context of draft TROA, the term drought situation means a year in which it seems likely that there either will not be sufficient natural flow and pooled water in storage in Truckee River reservoirs to meet Floriston rates through October 31, or the projected level of Lake Tahoe pooled water on or before the following November 15 will be below 6,223.5 ft, Lake Tahoe datum. This determination is based on the April 1 seasonal Truckee River runoff forecast assuming median precipitation after April 1. The occurrence of a drought situation affects other operations in the model, such as these.

1. The allocation of fish credit water and Power Company nonfirm M\&I credit water spilled from
Stampede Reservoir. In a drought situation, fish credit water is spilled before PCMICW. In nondrought situation years, PCMICW spills before fish credit water (see the section "Merge Reservoir Releases for Multiple Objectives," under "Proposed Reservoir Operations").

2. The transfer (conversion) of excess nonfirm M\&I credit water to fish credit water. This conversion takes place in any year that is not projected to be in a drought situation (see the section "Other Exchanges and Transfers," under "Proposed Reservoir Operations").

3. The priority for storage and accumulation of Power Company M\&I credit water and fish credit water (see the sections (1) "Other Exchanges and Transfers," and (2) "Power Company M\&I Credit Water, Fish Credit Water, Water-Quality Credit Water, and Joint Program Fish Credit Water," under "Proposed Reservoir Operations"). 

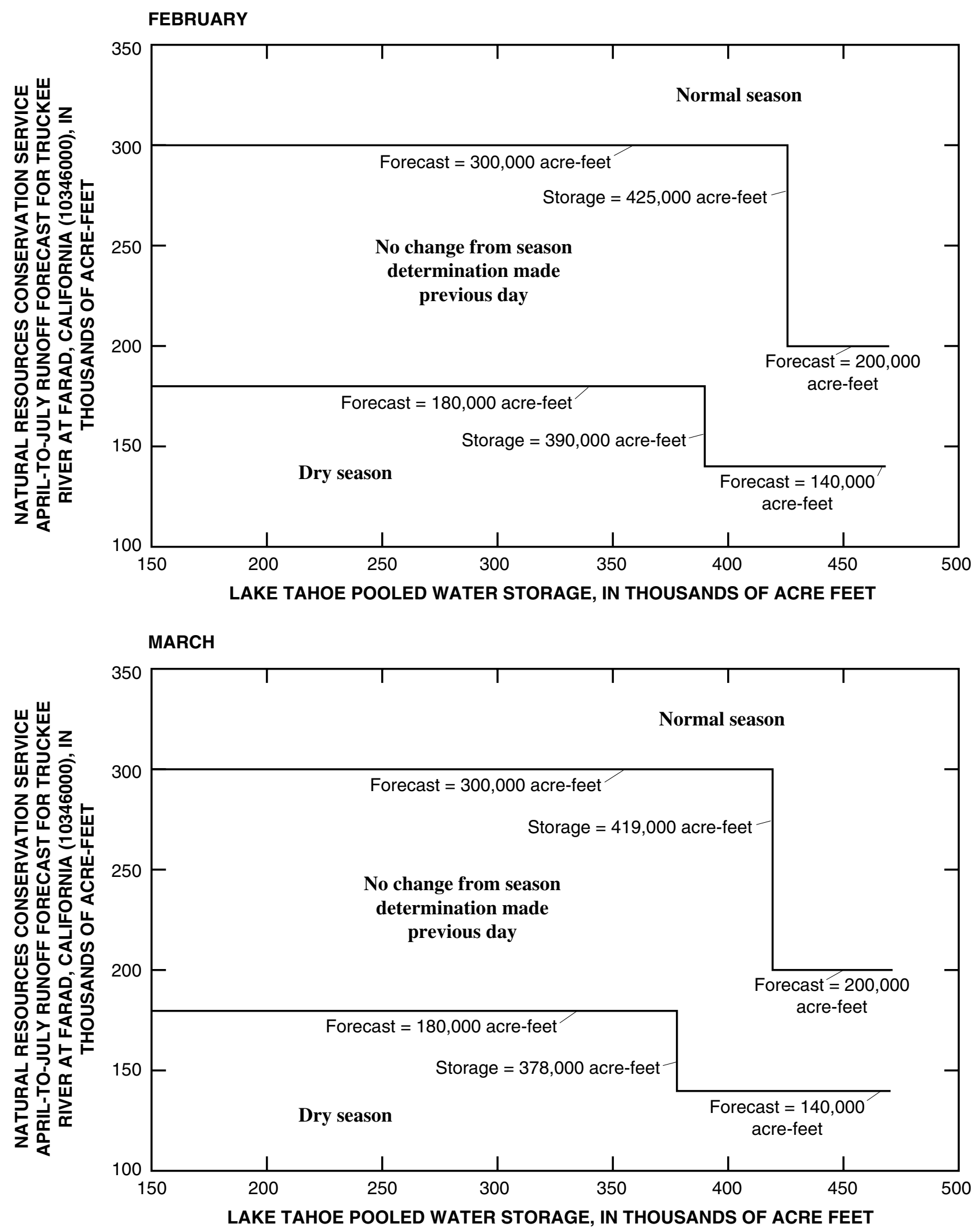

Figure 6. Determination of normal or dry seasons for Donner Lake, Prosser Creek Reservoir, Independence Lake, Stampede Reservoir, and Boca Reservoir, February-June 

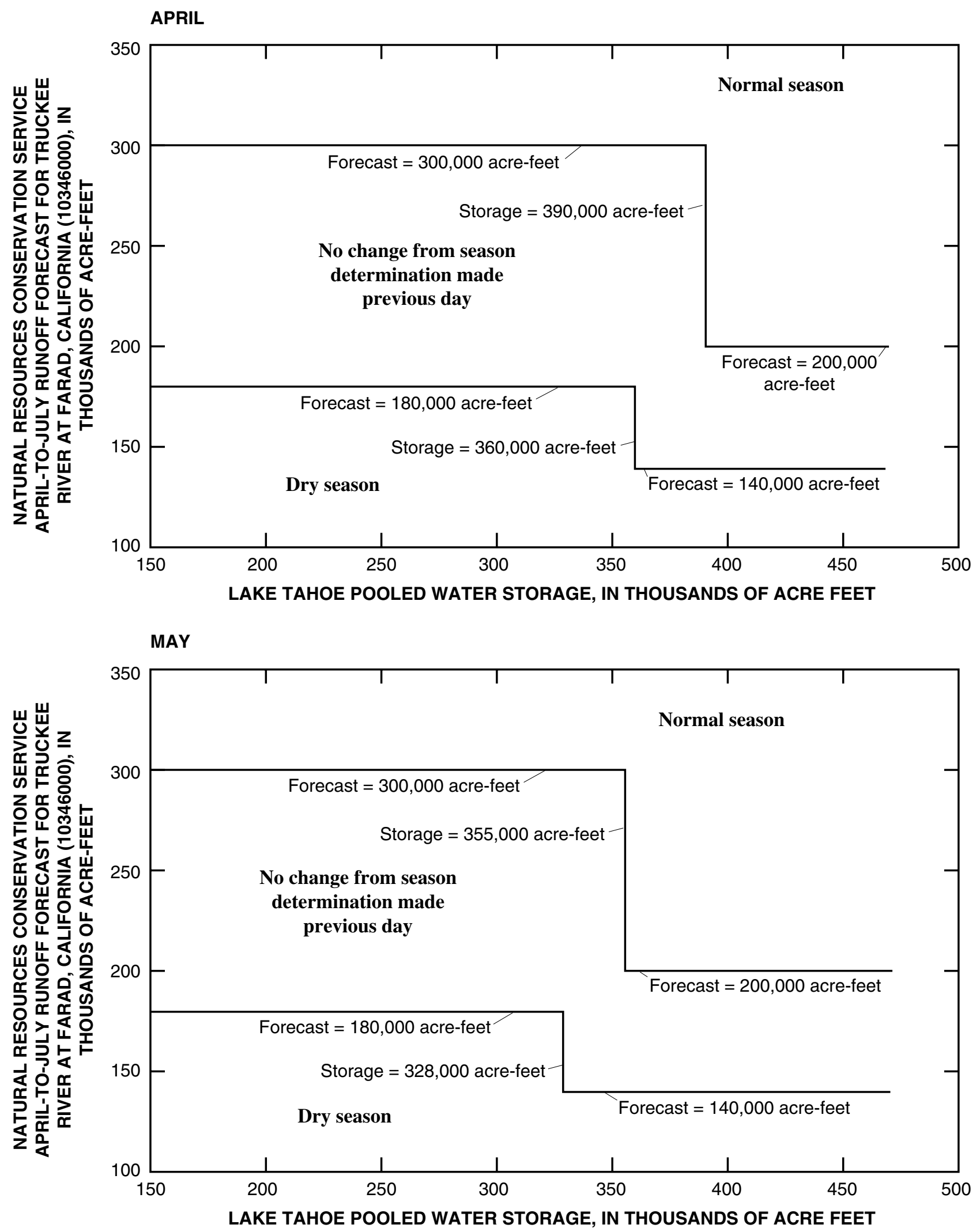

Figure 6. Determination of normal or dry seasons for Donner Lake, Prosser Creek Reservoir, Independence Lake, Stampede Reservoir, and Boca Reservoir, February-June-Continued 


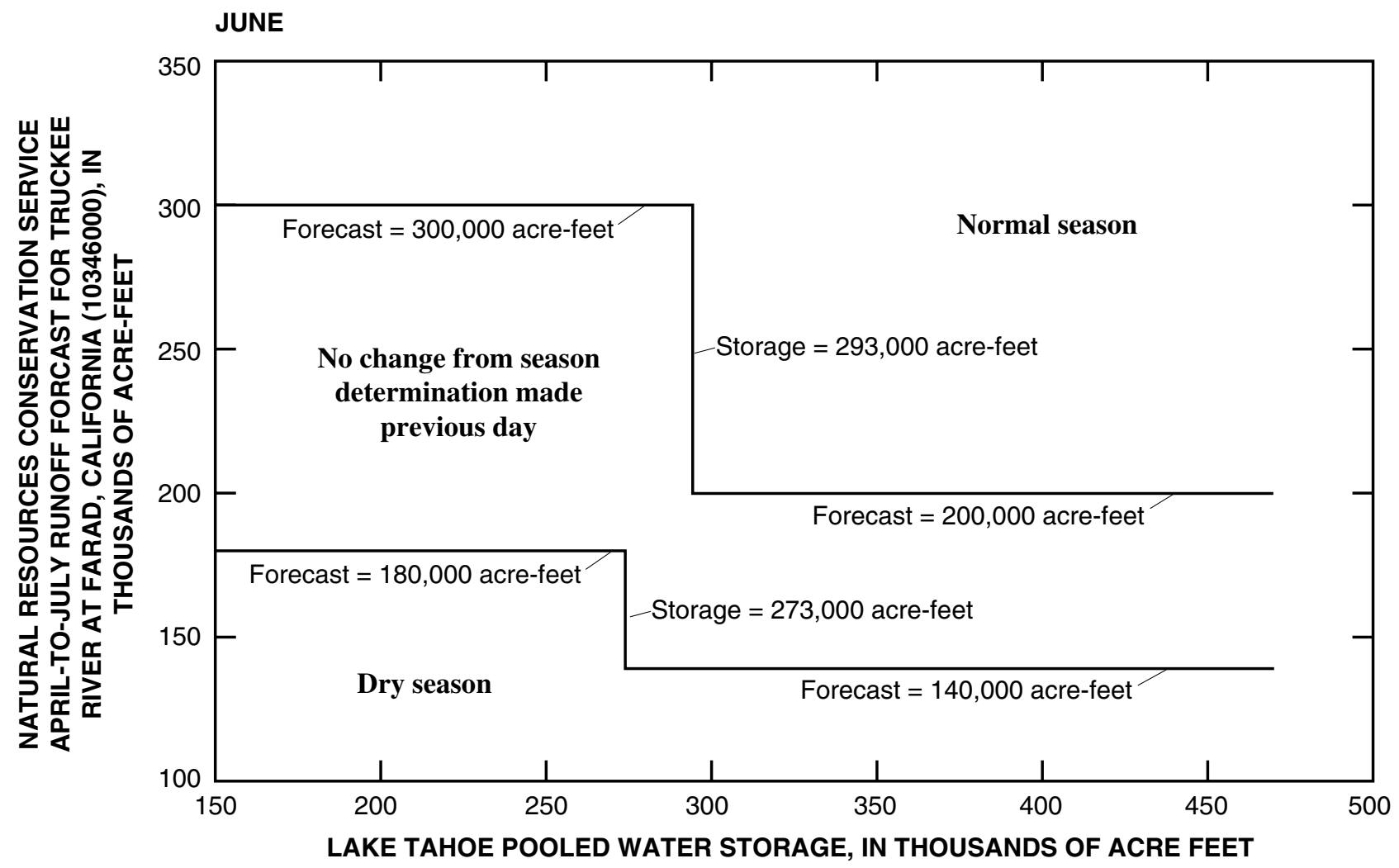

Figure 6. Determination of normal or dry seasons for Donner Lake, Prosser Creek Reservoir, Independence Lake, Stampede Reservoir, and Boca Reservoir, February-June-Continued

The operations model simulates the determination of a drought situation as follows. In general, the subblock initial assignments and computations determines a drought situation once each year on April 1st using forecasts of monthly runoff volumes for the next 8 months (April through November) at major streams within the Lake Tahoe and Truckee River Basins. Using these monthly forecasts at various locations, the model simulates selected major operations using 1month computation intervals for the period April through November. At the end of each month's operational computations, the model determines if a shortfall in Floriston rates has occurred or if Tahoe's pooled water elevation has fallen below $6,223.5 \mathrm{ft}$. This simplified operational forecast code within the model seeks only to satisfy the first few storage or demand priorities for water:

1. Fill Donner Lake.

2. First 3,000 acre-ft of storage in Independence Lake.

3. Floriston rates (demand).
4. Lake Tahoe storage.

5. First 25,000 acre-ft of Boca adverse-to-canal storage rights.

In the initial assignments and computations subblock, the storages and category amounts used by the drought situation code are the simulated amounts from the main HSPF model as of March 31st each year. The user must indicate, with a user option flag, whether the runoff forecasted time series to be used are net inflows to reservoirs (include the effects of evaporation and precipitation) or inflows only. If the forecasted time series for input to the reservoir are inflows only, they will be adjusted for precipitation and evaporation.

The following is an overview of the subblock simplified forecast procedure to determine drought situation, which computes (April 1 of every simulation year) whether or not a drought situation exists. This "condensed" version of operations described below is unique to this subblock and in no way reflects the complex interactions simulated in the other subblocks. 
1. Using forecasted runoff volumes for the month of April, the model checks whether the storage rights of Donner and Independence Lakes listed above have been satisfied.

2. Next, the model determines if Floriston rates can be met by sidewater and pass-through water from reservoirs. If not, pooled water (including Tahoe-Prosser Exchange water existing on April 1st in Prosser Creek Reservoir) is released from the reservoirs in the order specified by the Truckee River Agreement (see discussion in the section "Floriston Rates"). If, on the other hand, Floriston rates can be satisfied, then storage of the first 25,000 acre-ft of water in Boca Reservoir is allowed to begin.

3. At the end of the April calculations, if the water surface corresponding to pooled water in Lake Tahoe fell below 6,223.5 ft or if Floriston rates were not met, then a computed flag is switched from 0 (no drought situation) to 1 (drought situation exists). If the drought situation flag is set to 1 at any time during the calculations, the remainder of the monthly steps in this computation are skipped and operations in the other model subblocks will consider the period to be in a drought situation. If no drought situation is indicated after the April computations, the subblock computations proceed to simulate operations for the month of May using expected (forecasted) runoff volumes for that month.

4. The procedure is repeated using the forecasted runoff for each remaining month, May through November, and the end result of this subblock of code is a drought situation flag setting on April 1 of either 0 or 1 . This flag value is used in the daily computations of other subblocks until the following April 1, when a new flag value is computed once again.

Several assumptions were made in developing the code to determine the existence of a drought situation in the context of draft TROA. Some of the more notable assumptions follow.

- Because the purpose of this part of the code is to simulate Lake Tahoe water-surface elevation and the system's ability to maintain Floriston rates with pooled water, sidewater, and pass-through water, it was not necessary to simulate any storage with a lower priority than Donner Lake and
Independence Lakes (first 3,000 acre-ft), Lake Tahoe, and Boca Reservoir (first 25,000 acre-ft).

- No accumulation of storage attributable to the current year is assumed to have taken place in Independence Lake prior to April 1st of that year. Donner Lake's winter operations leave the outflow gates open, so no accumulation of storage before April 1 also can be assumed.

- Only the first 25,000 acre-ft (adverse-to-canal) storage rights are simulated in Boca Reservoir. The non-adverse-to-canal water (next 15,000 acre-ft) has a later storage priority than Truckee Canal diversions, and, for purposes of simplification, Truckee Canal operations were not simulated in this subblock.

- In this single-purpose subblock, developed only for forecasting, the only Tahoe-Prosser Exchange water in Prosser Creek Reservoir available for supporting Floriston rates is the simulated volume on April 1st. The Tahoe-Prosser Exchange is not simulated in this subblock of code. Because minimum flows from Tahoe are not simulated in this subblock, any water drafted from Tahoe is used for Floriston rates. So, instead of forecasting the release of minimum flows from Tahoe and exchanging pooled water into Prosser Creek Reservoir via the Tahoe-Prosser

Exchange, this subblock just keeps that water in Tahoe. This will not affect the forecast on whether Floriston rates will be met, but could make the forecast level of Lake Tahoe greater than it should be by as much as a tenth of a foot.

- If the pooled water elevation in Lake Tahoe ever exceeds 6,227.5 ft, as computed within this subblock, it is assumed that enough water exists to satisfy Floriston rates for the remainder of the year without the elevation falling below $6,223.5 \mathrm{ft}$ and the remainder of the drought situation subblock calculations are simply skipped and the drought situation flag is set to 0 , indicating a nondrought situation for use in other operational subblocks.

\section{Runoff Index}

In the management of the Truckee River Basin reservoirs and rivers, many operational decisions are based on expected runoff volumes, which in turn are based on snowpack conditions and historic USGS 
streamflow records. A runoff index is computed in the USGS Truckee River Basin operations model, and is used as a component of hydrologic judgement needed to make certain operational decisions. These operations include springtime reservoir filling for Donner and Independence Lakes, establishing beginning date of irrigation season, and determining ground-water use in the Truckee Meadows as described in their respective sections. Based on the historic NRCS forecasted flow data (1922-97) for the Truckee River near Farad streamflow station, the forecasted flows are split into three runoff groupings - wet, average, or dry years. Runoff groupings are defined using forecasted flow data and long-term mean runoff at Farad from historic USGS streamflow records. If the forecast is greater than the long term mean runoff plus one-half the standard deviation, the year is considered wet. If the forecast is less than the mean minus one-half the standard deviation, the year is considered dry. Otherwise, the year is considered average. This qualitative runoff index is used in both current and proposed reservoir operations.

\section{COMPARISON OF SIMULATED AND OBSERVED OPERATIONS}

The Truckee River Basin operations model was developed to provide water managers with a tool capable of simulating both hydrologic processes and river/reservoir operations using a daily, rather than monthly, computation interval. A daily model is needed to examine policies that can be affected by the dynamic nature of streamflow and river/reservoir operations that exist in the day-to-day management of water resources in the Truckee River Basin. Because the model is flexible, comprehensive, and documented, all interested parties can apply a common model to examine individual interests, allowing negotiations or the investigation of alternative management policies to proceed with the confidence that all parties can reproduce and verify the results. The model documented in this report is not intended for use in simulating historical streamflow. It was specifically designed to facilitate relative comparisons of the effects of alternative management practices or allocations on flows and storages within the system. Relative comparisons allow management to base decisions on whether a situation will improve or worsen under a proposed operating scenario. Exact water volumes attributable to changes in operations cannot be simulated, and results should not be considered to be anything other than reasonable estimates.

Traditional model development usually entails calibration and verification tasks to demonstrate the reliability of the model. Because observed streamflows are not meant to be reproduced by this model, a classic calibration comparing observed and simulated volumes or streamflows is problematic with this model and its current databases. However, the physically based flowrouting processes embedded in the operations model were evaluated in a previous report by Berris (1997).

Currently (1998), TROA has not yet been signed and implemented and, therefore, no observed data resulting from the proposed operations exist that could be used for comparison. Testing the simulation of current operations by the model also is difficult for a number of reasons explained in the paragraphs below.

First, the complexity of actual historical and current river and reservoir operations in the Truckee River Basin has been compounded by unique, one-time agreements that deviated from "normal" operations. The operations model does not simulate any of these one-time agreements. Dated operations could have been coded to account for known deviations, but, because the reasoning behind these actions was not always documented and it was not known if such actions would ever be taken again, simulation of such one-time operations were not programmed into the model.

Second, there have been many times when nonroutine, minor operations have been executed in the Truckee River Basin. Although these operations were allowable, they were not documented in specific legal decrees or agreements. The USGS Truckee River Basin operations model does not simulate such nonroutine operations.

Third, there is considerable flexibility in how the reservoirs can be managed to meet the objectives of major decrees and agreements. This human element of judgement allows basin managers to implement required operations differently every year and not exactly according to rules or stipulations explicitly documented in any one decree or agreement. The interactions between the reservoirs are very complex and are often undocumented and inconsistent. The operations model attempts to simulate these interactions with a simplified logic using the same method from year to year, but the logic cannot simulate all possible interac- 
tions and variable human judgement. Thus, the course of action simulated by the operations model will be the same each year under equal conditions.

Finally, there may be differences between the input data used in model simulations and the available data that guided the historic operations. For example, except for Lake Tahoe, reservoir inflows used in testing the operations model were taken from PRMS simulations (Jeton, 2000). Additionally, the use of PRMS models allows for the determination of inflow forecasts required by the operations model. Observed reservoir inflows for 1933-97 were not available due to limited data sets and varying dates of Truckee River reservoir construction. Forecasts of streamflow volume is another example of input data that may be different from that used historically by system managers.

The above factors affecting model input data and actual reservoir operations make side-by-side comparisons of observed and simulated data difficult, if not impossible, to reconcile. In view of these constraints, only limited testing of the USGS Truckee River Basin operations model by comparison with historical data can be accomplished. Simulations of Truckee River streamflow were made by applying historical and synthesized channel and reservoir inflow time series to conditional logic in the HSPF SPECL block. The synthesized inflow time series determined from PRMS simulations were used when observed data were not available. Simulations for the water years 1989-97 and 1933-97 were made for the Truckee River Basin. Because TROA has not yet been implemented, only current operations were simulated for comparison with observed streamflows in this test.

The period 1989-97 was chosen to test the simulation of reservoir and river operations because it is the most representative of the current operating strategy that was coded in the model, all storage reservoirs were present, operations were relatively consistent over this period, and better documentation of all operations in the basin was available beginning at about that time. Because Truckee Canal diversions dictated by the 1988 OCAP played a major role in determining river operations, that year was chosen to begin simulations.

The period 1933-97 was chosen to test the simulation of streamflow volumes by evaluating the overall difference between observed and simulated streamflows over a long period. Although not all storage reservoirs and current operations were in place for this entire period, it is assumed that over a long period of time that encompasses several decades, the seasonal and annual effects of reservoir operations will be small compared to the longer term patterns of streamflow volumes.

There are many possible geographic locations and hydrologic characteristics (such as reservoir storage volume, flow duration, and so forth) for which comparisons could be made. Streamflow in the main channel is an easily measured and comparable response that integrates the many complex and interrelated operations in the basin. Because river and reservoir operations are reflected in downstream flows, and to simplify what could be lengthy and detailed comparisons, graphical comparisons of observed and simulated streamflow at three sites along the Truckee River are provided for the 1989-97 comparisons: Truckee River at Farad, Calif., Truckee River at Vista, Nev., and Truckee River near Nixon, Nev. (figs. 7-9).

To simplify the graphs and facilitate visual comparison of simulated to observed flows, model outputs of daily mean flows were condensed to monthly means for these illustrations. A simple quantitative comparison of observed and simulated streamflow volumes for the 1933-97 period at the Farad gage, is discussed below to evaluate long-term differences between historical and simulated streamflow volumes rather than to evaluate differences between historical and simulated reservoir and river operations.

As can be seen from figures 7-9, the simulations with the operations model reflect quite well the general timing and magnitude of observed monthly flows. For example, in January 1997, which contained high flows, model simulations adequately represent observed flows. Also, during the drought years of 1990-91, model simulations characterized the low flows of the period.

Figures 7-9 show simulated monthly mean flows at Farad, Vista, and Nixon during the spring of 1989 to be higher than actually observed. This probably is due to some combination of one-time operations and higher simulated storage levels in Lahontan Reservoir. Several one-time operations occurred from 1988-90 (Jeff Boyer, U.S. District Court Water Master, oral communication, 1998). For example, a special permit to store water in Prosser Creek Reservoir for fish and wildlife concerns was issued in March 1989. The water was kept in storage for the next year and flood-control releases from Prosser Creek Reservoir were not made during the normal precautionary drawdown period. Additionally, work on the release gates at Lake Tahoe's outlet required some one-time operational 


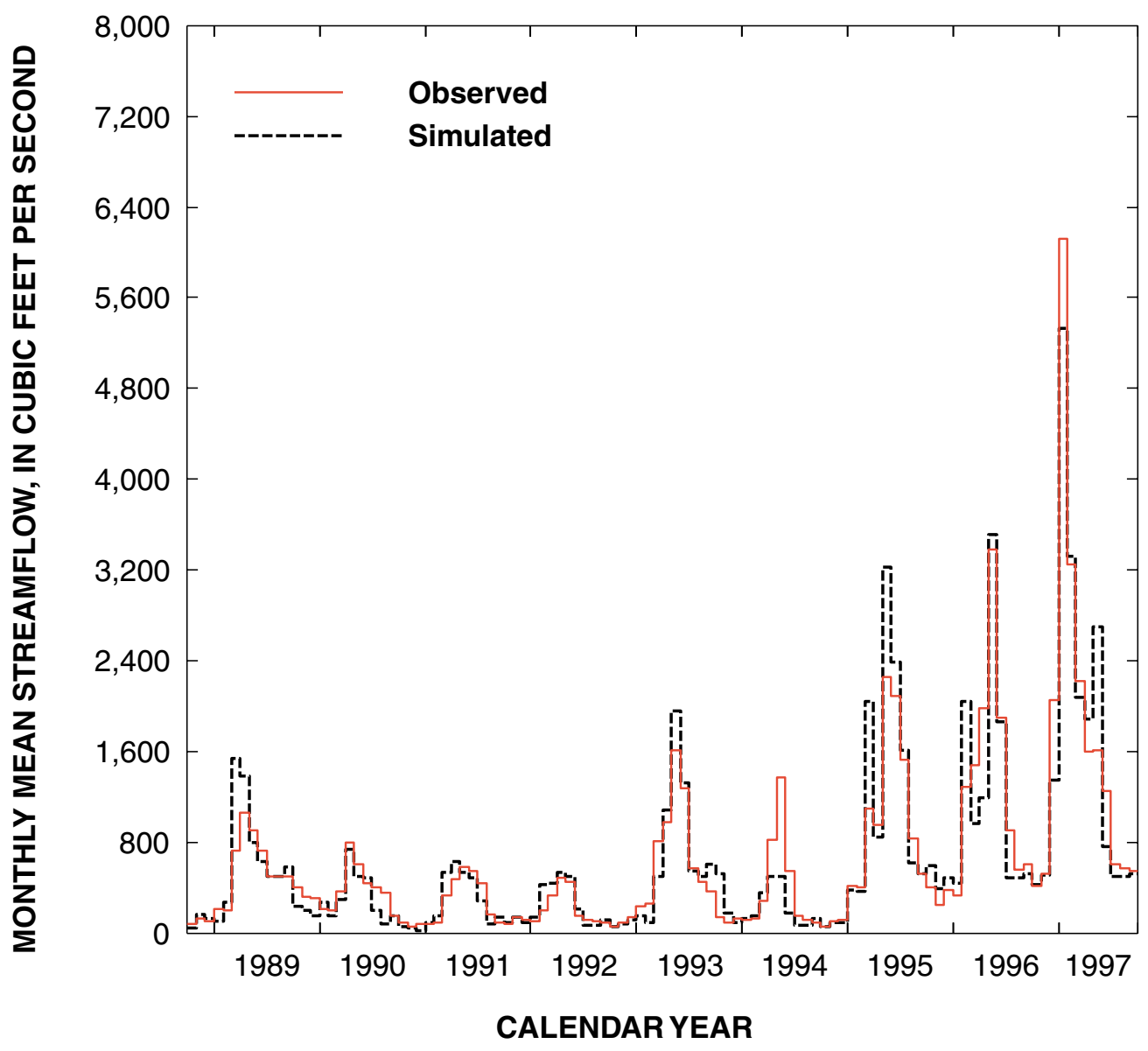

Figure 7. Observed and simulated monthly mean streamflows for the period October 1, 1988, through September 30, 1997, for Truckee River at Farad, Calif. (station 10346000)

decisions to protect water rights in Nevada. These onetime operations may have changed water categories in the river, resulting in slightly modified river operations in the Truckee Meadows and even greater differences related to OCAP diversions to the Truckee Canal at Derby Dam. These complex interactions were not simulated by the operations model. Finally, simulated storage levels in Lahontan Reservoir were higher than observed. As a result, less water was simulated for diversion to the Newlands Project via the Truckee Canal, allowing extra water to flow to Pyramid Lake.

The simulated monthly mean flows at Farad, Vista, and Nixon during the spring of 1994 also are lower than observed. This probably is due to a one-time operation that provided spawning flows for cui-ui during the spring of the drought year of 1994. The 1994 runoff season was considered the last year of the drought, which lasted from 1987 to 1994 . Under "normal" operation, a fish run generally will not occur in dry years. However, a fish run (flow regime 1) was not simulated by the operations model because the simulated total fish water in storage in Truckee River Basin reservoirs and the forecasted inflows were lower than the conditional logic allows as necessary for a fish run. This one-time operation of a fish run was not simulated by the operations model. Lastly, for the winter of 1996, flows were overestimated in February and underestimated in the spring of 1996. This is due to simulated reservoir releases earlier than in actual operations.

A simple quantitative comparison of observed and simulated streamflow volumes for the period 1933-97 at the Farad gaging station describes longterm differences for evaluation of simulated streamflow volumes. Percent bias of simulated versus observed streamflows is used as the statistical measure for the evaluation. For this 65-year period, long-term average streamflows, rather than mean monthly or daily, were used to reduce the effects of daily opera- 


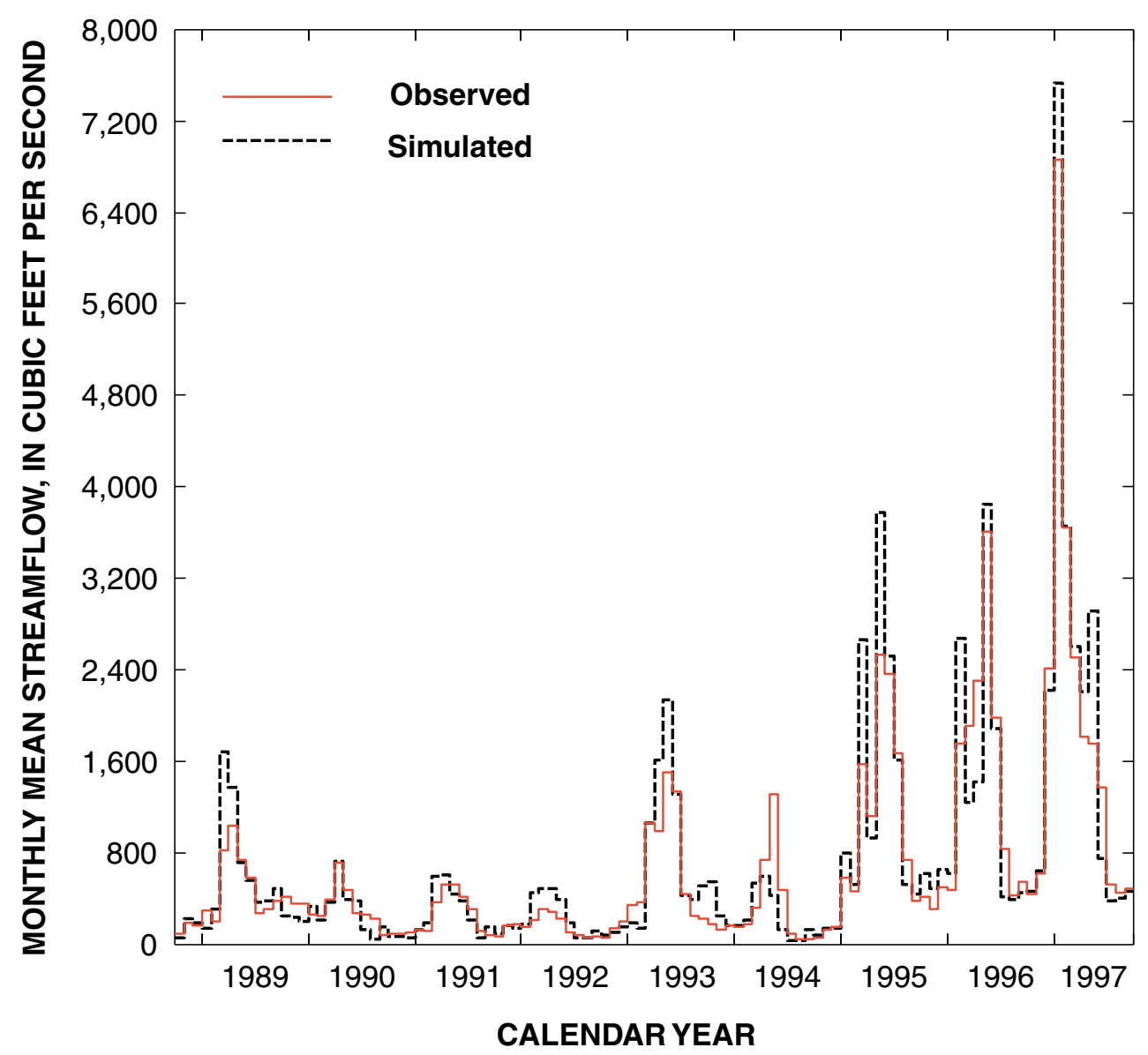

Figure 8. Observed and simulated monthly mean streamflows for the period October 1, 1988, through September 30, 1997, for Truckee River at Vista, Nev. (station 10350000)

tions variations and other short-term variations while reflecting longer-term patterns of streamflow volumes. For the period 1933-97, the percent bias of simulated mean annual streamflow was -13 percent at the Farad gaging station.

The period 1933-97 was split into two separate periods, 1933-80 and 1981-97, to further evaluate differences in observed and simulated streamflow volumes. The two periods allow for streamflow comparisons between modern and historical periods of different inflow data provided as input to the operations model and different reservoir configurations upstream from Farad. Operational variables, such as different effective dates of decrees and agreements, flexible adherence to decrees and agreements, and other unknown or minor operational variables may also influence simulation results, but they are difficult to identify and their influence on simulation results is difficult to specify.
For the periods 1933-80 and 1981-97, percent biases at the Farad gaging station were -18 percent and -2 percent, respectively. Differences between the inflow data used in model simulations and actual inflows between the outlet of Lake Tahoe and Farad are an important reason for the negative bias between simulated and observed flows. It is likely that errors from PRMS simulations of inflows, the use of synthetic meteorological data used as input for PRMS simulations of inflows, and different reservoir configurations contribute toward the negative bias at Farad prior to 1981 .

Simulation errors from PRMS models contribute toward the percent bias at Farad. The PRMS models were calibrated only for the water years 1980-97 or 1994-97 for most of the modeled subbasins in the Truckee River Basin between Lake Tahoe and the Farad gaging station. Percent bias from PRMS model simulations range from -7 to +7 percent for calibrated 


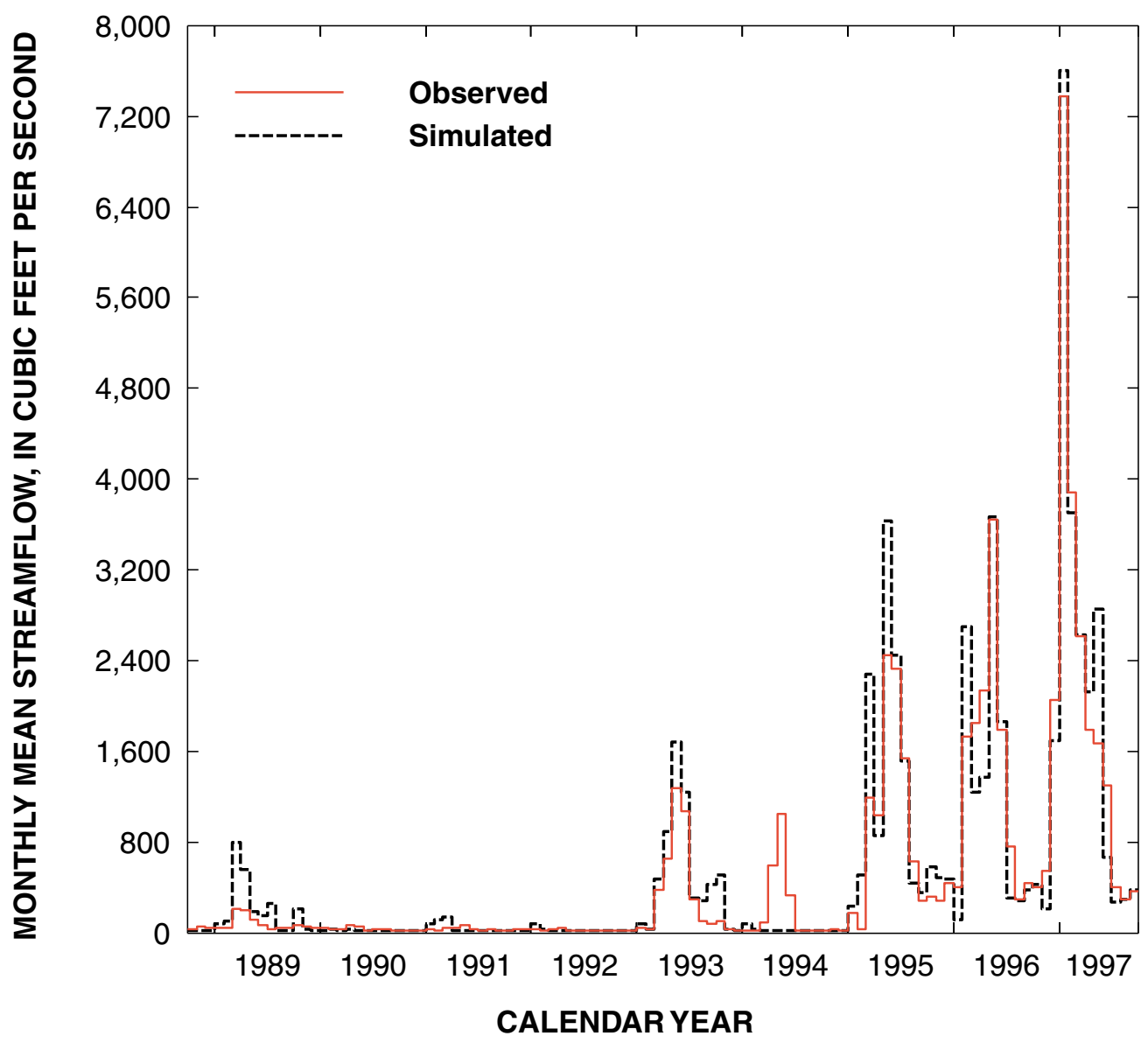

Figure 9. Observed and simulated monthly mean streamflows for the period October 1, 1988, through September 30, 1997, for Truckee River near Nixon, Nev. (station 10351700)

subbasin models upstream from Farad (Jeton, 2000). The PRMS models were calibrated to only 5 of 14 subbasins, which comprise only about 30 percent of the total drainage basin area between Lake Tahoe and Farad. Observed data from the other nine subbasins were not available for model calibration. Additionally, the accuracy of simulated streamflow data prior to the period of PRMS model calibrations, as described above, is uncertain. PRMS simulation accuracies could be improved by increased availability of observed streamflow data for model calibrations.

The meteorological data used as input to the PRMS models for simulation of inflows to the operations model also contribute toward the percent bias at Farad. For the water years 1981-97-the period of -2 percent bias-observed meteorological data were used for PRMS simulation of inflows. However, for the period 1933-80 - the period of - 18 percent bias- synthetic meteorological data (Michael Dettinger, U.S. Geological Survey, written commun., 1998) were used to simulate most of the PRMS inflows.

Different reservoir configurations between Lake Tahoe and Farad also contribute toward the negative bias at Farad. The operations model simulates the operations of seven reservoirs upstream of Farad for the period 1933-97, but Prosser Creek Reservoir, Stampede Reservoir, and Martis Creek Lake were not constructed until 1962, 1970, and 1971, respectively (table 1). The simulation of evaporation from these three reservoirs prior to their actual construction contributes toward simulated losses of water volumes resulting in negative simulation errors. The effects of bank storage and release from these reservoirs are not known, and it is uncertain how bank storage would affect simulation errors. Additionally, errors from the simulation of operations from these reservoirs prior to their construction are not known. 


\section{MODEL LIMITATIONS, ASSUMPTIONS, AND SUGGESTED IMPROVEMENTS}

Simulation of the hydrologic and physical processes in the channel and reservoir network of the Truckee River Basin using HSPF is, by itself, a rigorous and data-intensive undertaking. That task is made even more difficult by the need to simulate the complex operations (both current and anticipated) in this basin. Development of the operations model required skill and experience in modeling with HSPF, the assembly of a large data base, and an extensive knowledge of current and proposed operations in the basin. The sheer size of the computer program, the necessary integration of complex code from several programmers, the need for critical review from a variety of Truckee River interests, and the ongoing nature of the TROA negotiations to define operational policy all point to a need for future revisions, upgrades, and maintenance. This model is expected to evolve and be improved through purposeful application and analysis of the output.

The following bulleted items summarize some more general limitations, assumptions, or improvements that may be important to the reader in interpreting model output.

- All models are conceptual representations of the real world. Just as physically based models that simulate precipitation-runoff processes have inherent errors because detailed physical processes have been lumped together and averaged, so, too, will operational models of complex river basins. Further analysis of results will be necessary in order to refine the model logic, especially that logic that represents the human element rather than prescribed actions that are clearly spelled out in legal decrees and agreements.

- Although an attempt was made to include all significant aspects of draft TROA in the model, time constraints meant that some minor aspects in the draft TROA were not included. Where known, these omissions are mentioned in the assumptions listed for each section. It is possible that other aspects were inadvertently omitted and thus may be absent from the model and discussions in this report. Finally, some minor details may have been left out of the report for the sake of brevity but are present in the flowcharts and code and are, in fact, simulated by the model.
- With modification of the database, the operations model would have the capability to accept forecasted data for near-term simulations of current operations or draft TROA operations for planning purposes. This improvement would allow model simulations using near real-time data, such as forecasted streamflow data derived from current snowpack data and median climate conditions. Such capability would aid users in planning operations for an upcoming runoff season. However, without extensive changes to the model code, these planning simulations would be restricted to those operations coded in the model.

- Reliable data are unavailable to fully account for all inflows and outflows in the Truckee River Basin. These include measured reservoir and tributary inflows and meteorological data such as precipitation and evaporation. Errors in volume resulting from lack of data or inaccurate data may be either compensating or cumulative. Therefore, the magnitude of simulation differences resulting from the data are not fully known.

- Some water rights in the Truckee River Basin may be satisfied with ground water rather than surface water. Various amounts and locations of ground-water pumping are not addressed by this model. To do so would require linking the operations model to a calibrated ground-water model similar to Maurer (1986).

- There are few quantitative data on irrigation return flows, which are estimated in the model simulations using factors applied to the diversion amounts.

- Temporary diversions that return almost all water back to the river within a few miles, such as diversions to riverside power plants, are not simulated.

- The flow-routing part of the model for the Truckee Canal (reaches 60-69) and the Little Truckee River (reaches 185-209) has not been tested against observed streamflow data. Methods to construct the Truckee Canal and Little Truckee River parts of the flow-routing model were similar to those used in the Truckee River (Berris, 1996) and the Carson River (Hess, 1996) flow routing models. Very little observed flow data or diversion data are available to compare observed and simulated daily streamflows for these added reaches. 
- For simulation of Lake Tahoe releases of pooled water for maintaining Floriston rates, the watersurface elevation of Tahoe includes all water categories in the lake, but does not reflect pooled water volume stored in any other reservoir as specified in draft TROA.

- The simulation period for which daily input data have been compiled or estimated for the operations model is currently October 1, 1932, to September 30, 1997. Simulations can be made for any period of time for which the user has complete daily data. However, the modeler would have to revise several dated variable assignments within the SPECL block. There are, for example, several computed flags, storage accumulators, and so forth that are computed on specific dates within the program code and used to guide operations in subsequent months. If the user opts to start a simulation on a day other than October 1, 1932, initial values for these variables would have to be individually assigned. Inappropriate or overlooked assignments could result in errors that may carry through the simulation period. Other initial conditions required for simulations, such as reservoir storages and water category amounts in all reaches, inflows, and so forth, must be specified by the user.

- To realize multiple-use benefits of reservoirs in the Truckee River Basin when determining releases, managers can utilize blending or seasonal foresight or some combination of the two concepts. Blending of reservoir releases satisfies a demand for one category of water by concurrent releases from more than one reservoir. Current examples of blending used by managers are multiple-reservoir releases to maintain Floriston rates, to meet Pyramid Lake fish flow targets, to maximize power generation, and to satisfy floodcontrol criteria. Methods describing current or draft TROA reservoir management for the purpose of blending are undocumented.

- Seasonal foresight utilizes forecasts of both inflows and reservoir management to construct an operational forecast. Such a forecast can be used to "schedule" operations in advance, smoothing reservoir releases over weekly/monthly periods and thus avoiding large operational swings. As with blending of reservoir releases, methods describing reservoir management using seasonal foresight are undocumented. Examples of where seasonal foresight would be useful are storage of proposed water categories, maintaining preferred instream flows, and maintaining recreational pools.

- In the USGS Truckee River Basin operations model, there are no specific subblocks that simulate scheduling, blending, or seasonal foresight procedures. Instead of blending releases, the operations model draws upon one reservoir at a time to satisfy demands, taking into account recreational pools. However, some blending is accomplished in model simulations of draft TROA operations by making exchanges to achieve various instream flows, recreational pools, and enhanced storage security. Additional blending in the model would require defining the relation between reservoir levels and releases for multiple-use benefits. To simulate the use of scheduling and seasonal foresight, would require pseudo-operation forecasts that, to be accurate, would require much more coding and would significantly increase model run times.

\section{SUMMARY}

The demand for all uses of water in the Truckee River Basin, California and Nevada, commonly is greater than can be supplied. Droughts lasting several years, such as the recent drought of the late 1980's and early 1990's, can result in substantial water shortages for irrigation and municipal users and may stress fish and wildlife ecosystems. Truckee River water is used to enhance fishery and recreational resources in California, to generate power upstream from Reno, to provide municipal and industrial (M\&I) water supply in the Truckee Meadows vicinity, to maintain Pyramid Lake levels, to conserve the Pyramid Lake fish species cui-ui and Lahontan cutthroat trout, and to provide irrigation water to the Truckee River Basin and, through transbasin diversion, the Carson River Basin. This diversity in interests results in a wide range of alternatives for planning, allocating, and managing the water resources and operating the various reservoirs and diversion systems. Decrees, agreements, and regulations generally define current water management in the basin. 
Title II of Public Law (P.L.) 101-618, the Truckee-Carson-Pyramid Lake Water Rights Settlement Act of 1990, provides direction, authority, and a mechanism for resolving conflicts over water rights in the Truckee and Carson River Basins. P.L. 101-618 provides a foundation for the negotiation and development of reservoir and river operating criteria, known as the Truckee River Operating Agreement (TROA), to balance interstate and interbasin allocation of water rights among the many interests competing for Truckee River water. Additionally, the Truckee River Water Quality Settlement Agreement (WQSA), signed in 1996, provides for acquisition of water rights to aid in resolving water-quality problems during periods of low flow on the Truckee River in Nevada while simultaneously providing additional water for fish and wildlife resources. Efficient execution of many of the planning, management, or environmental assessment requirements of TROA and WQSA will require detailed water-resources and hydraulic data, coupled with sound analytical tools. Models constructed and evaluated with reliable data will help assess effects of alternative operational scenarios related to reservoir and river operations, water-rights transfers, and changes in irrigation practices. The dynamic nature of certain reservoir and river operations, coupled with the interdependence of water-quality to dynamic flow regimes, dictate the use of a model that can characterize and represent the physical hydrologic and hydraulic features of the basins and the river/reservoir operations, and can simulate flow with a computation interval sufficient to represent these dynamics, such as a daily time step. However, available modeling tools have a monthly time step and cannot simulate dynamic flows. Such models cannot fully address the broad spectrum of water-resources issues associated with the dynamic nature of operations, flows, and water quality in the quantitative detail that is needed for evaluation of management options.

The Truckee-Carson Program of the U.S. Geological Survey, to support U.S. Department of the Interior implementation of P.L. 101-618, developed a modeling system to assist in the efficient planning, management, and allocation of water resources. The daily operations model discussed in this report is a part of the modeling system. The operations model utilizes flow-routing and operations modules. The operations model is capable of simulating lake/reser- voir and river operations, including diversion of Truckee River water to the Truckee Canal for transport to the Carson River Basin.

This report describes the chronology and background of decrees, agreements, and laws that affect Truckee River operational practices; the construction of the Truckee River daily operations model, including the data necessary for simulations; the simulation of Truckee River Basin operations, both current and proposed under TROA and WQSA; suggested model improvements and limitations; and a comparison between simulated and observed operations. The daily operations model simulates river and reservoir operations as well as streamflow in the Truckee River from Lake Tahoe to Pyramid Lake, the Truckee Canal, and Lahontan Reservoir in the Carson River Basin. The daily operations model was designed to provide simulations that allow comparison of the effects of alternative management practices or allocations on streamflow or reservoir storages in the Truckee River Basin. The model was not intended to reproduce historical values. A general overview of daily operations (current and proposed) and how they are simulated is provided in this report. In addition to this report, supplemental information that documents the extremely complex operating rules is available, including detailed flowcharts, original model code, and a listing of variable names and definitions found in the flowcharts and code.

The daily operations model uses the Hydrological Simulation Program-FORTRAN (HSPF) to simulate streamflow and reservoir and river operations. HSPF was chosen because it can (1) simulate continuously over time, including periods of storm runoff and low flows, (2) simulate at a daily time step, (3) simulate the hydraulics of complex natural and man-made drainage networks, (4) produce simulation results for many locations along the river and its tributaries, (5) simulate reservoir and river operations, and (6) compute a detailed water budget that accounts for inflows and diversions as well as different categories of water in the river and reservoirs. HSPF is an internationally used non-proprietary program maintained by the Environmental Protection Agency.

Reservoir and river operations for the Truckee River Basin are governed by complex rules in legal agreements, decrees, and regulations that specify numerous conditions for the distribution and use of water categories. The Truckee River Basin operations model simulates reservoir and river operations by 
evaluating specific conditions and executing the appropriate operations through the use of model code. Conditions that are typically evaluated during simulations include the time of year, reservoir stage, reservoir storage, volume of a given water category in a reservoir, streamflow magnitude, and fulfillment of demands.

The Truckee River daily flow-routing model developed by Berris (1996) is used within the operations model to model the movement of water into and through the reaches of the drainage network while the operations model simulates the man-made regulation of water movement within and out of the Truckee River Basin drainage network. The scope of the flow-routing model was expanded from 47 reaches to 72 reaches for use with the operations model.

External input data are required for streamflow and operations simulations. These include time series of daily reservoir inflows, river inflows, channel seepage losses, evapotranspirations losses from phreatophytes, precipitation, evaporation, M\&I demand for the Truckee Meadows, and various types of runoff forecasts.

The constructed model simulates three major options regarding Truckee River operational practices. The first simulates current (1998) operational practices. The second combines current operations and those proposed in draft TROA and WQSA. The third simulates WQSA without draft TROA, and is not described separately in this report. All simulated operations are organized into subblocks of model code. Current and proposed operations, organized into subblocks of model code, can be grouped into the general classifications: (1) initial assignments and computations, (2) flood-control criteria, (3) storage priorities, (4) release adjustments to meet downstream demands, (5) merged reservoir releases for multiple objectives, (6) river diversions, and (7) exchanges or transfers of water categories among one or more reservoirs.

Initial assignments and computations is a utility subblock in which miscellaneous constants and flags are assigned prior to the simulation of operations. These assignments include reservoir outlet capacities based on current reservoir stage; irrigation demands transferred to other uses, such as M\&I demand or water-quality demand; minimum, enhanced, and preferred flow targets; recreation pool levels; Floriston rates targets; and M\&I credit water base amounts.

Current reservoir and river operations are implemented primarily by adjusting reservoir releases and diverting water of specific water categories from the main channel. Adjustment of reservoir releases allows the reservoir operator to pass inflows through to downstream reaches, store inflows, or release water from reservoir storage for a variety of objectives. River diversions to meet irrigation and M\&I demands are based on water rights. Operations currently practiced and simulated are briefly described below.

Truckee River reservoirs are currently operated according to several types of flood-control criteria throughout a given year. Flood-control criteria are simulated by adjusting reservoir releases of precautionary drawdowns and uncontrolled spills.

A reservoir storage priority system is used in the Truckee River Basin to determine when a reservoir may or may not store water. Storage priorities must consider Floriston rates demands and Newlands Project demands for Truckee River water. Reservoir storage is simulated by adjusting reservoir releases.

Under current operations, several demands are described in legal decrees and simulated by the operations model. Satisfying these demands involves adjusting reservoir releases and river diversions. Demands met by operational simulations include Floriston rates, instream flows, Pyramid Lake fish, Newlands Project, and privately owned stored water (POSW), such as Power Company POSW (PCPOSW) and TruckeeCarson Irrigation District POSW (TCIDPOSW). The water categories pooled water and Tahoe-Prosser Exchange water are used to maintain Floriston rates. The water categories fish water and uncommitted water (only that part not needed for the purposes of the Tahoe-Prosser Exchange Agreement) serve to benefit threatened and endangered fish of Pyramid Lake. The POSW categories, PCPOSW and TCIDPOSW, are used to meet, in part, Truckee Meadows M\&I and Newlands Project demands, respectively.

For simulations, releases from a given reservoir that meet more than one objective may be consolidated as a "merged reservoir release." Untagged releases that are not required to be of specific categories, such as uncontrolled spills and precautionary drawdown releases based on flood-control criteria, or maintenance of current minimum flows, may be combined with releases tagged to specific categories. If the demand for untagged releases is greater than for tagged releases, then water categories must be assigned to that part of the untagged releases that is greater than the tagged releases, according to a rank-order list. 
River operations involve the diversion of pooled water, POSW, or natural water as specified in legal decrees, such as the Sierra Valley Settlement Agreement or the Orr Ditch Decree. Simulated river operations include (1) the Sierra Valley Diversion, which diverts water from the Little Truckee River for agricultural demands in California outside of the Truckee River Basin, (2) Truckee River diversions between the Farad and Vista gaging stations for M\&I and agricultural demands in the Truckee Meadows, (3) Truckee River diversions downstream from Vista gaging station for agricultural demands of adjacent agricultural lands, and (4) diversion of Truckee River water at Derby Dam to the Newlands Project via the Truckee Canal based on Operating Criteria and Procedures (OCAP).

Water exchange and transfers allows reservoir operators to meet multiple-use goals by manipulating volumes of water categories in one or more reservoirs. Exchanges involve moving stored water of a given water category from one reservoir to another. There are three types of exchanges: (1) a paper exchange-nonphysical exchanges of a volume of water in one or more reservoirs for water in one or more other reservoirs;

(2) in-lieu-of exchange - release of one or more categories of water from one or more reservoirs in lieu of a release of water of yet another category from one or more other reservoirs; and (3) re-storage-release of water from one reservoir for storage in a downstream reservoir. Two common exchanges currently practiced and simulated by the operations model are the TahoeProsser Exchange and the Donner-Boca Exchange. These exchanges are simulated as in-lieu-of exchanges. Transfers involve only one reservoir and result in the gain or loss of water in one category by transfer from another within that single reservoir.

The draft TROA agreement, unsigned as of 1998, and the WQSA agreement, signed in 1996, are designed to make more effective and efficient use of water categories in reservoir operations to meet multiple objectives. Reservoir and river operations outlined in draft TROA and WQSA are intended to (1) increase the drought water supply for M\&I uses in the Truckee River Basin in California and the Truckee Meadows, (2) increase the water supply to maintain adequate lake levels and spawning flows to promote the recovery of endangered and threatened Pyramid Lake fish, (3) increase instream flows for fish and water quality, and (4) maintain reservoir storage levels for recreation use. Achieving these objectives may be accomplished by revising many of the current operations regarding water storage and release practices. Two key elements of draft TROA and WQSA enable such changes to current operations. The first element involves reducing releases for Floriston rates, the required flow at the Farad gaging station. Water not released for Floriston rates would be retained in storage and transferred to new credit water categories available only to satisfy those objectives outlined in draft TROA and WQSA. The second element involves mandatory or voluntary exchanges of water categories between reservoirs to better coordinate releases to meet multiple objectives.

Draft TROA and WQSA specify procedures for storage of credit water categories in Lake Tahoe and reservoirs of the Truckee River Basin. These procedures allow for the storage of several categories of water within a reservoir. These procedures commonly involve a transfer of water categories retained in storage that would have been released under another set of circumstances, such as under current operations. The water retained would then be transferred to a new credit water category. Procedures for storage of credit water categories also involve a variety of other types of mandatory exchanges and transfers. Policies and operational procedures regarding some of the proposed water categories are not yet defined in the draft TROA. As a result, the proposed water categories, referred to as Fernley credit water, Newlands Project credit water, and other credit water were not coded, are not simulated in the operations model, and are not described in this report.

Under draft TROA, California could store a part of its unused surface-water allocation in Truckee River reservoirs for M\&I purposes. The new category, California M\&I Credit water (CMICW) is created in Lake Tahoe to provide an additional water supply during droughts. CMICW is accumulated in simulations by determining if the projected demand for direct diversion of surface water is less than California's surface-water allocation. If so, then the difference is available for accumulation of CMICW in Lake Tahoe. A new category, called Joint Program fish credit water (JPFCW), may be available in simulations for accumulation, based on the remaining allocation of surface water after California M\&I use and storage of CMICW. JPFCW is used to meet recreational and instream flow demands.

In addition to $\mathrm{CMICW}$, draft TROA will provide procedures for storage and accumulation of a number of other categories, such as Power Company M\&I credit water (PCMICW), fish credit water, water- 
quality credit water (WQCW), and Joint Program fish credit water (JPFCW). PCMICW, used as M\&I drought supply in the Truckee Meadows, is accumulated during simulations by (1) creating and accumulating the consumptive use portion of former Orr Ditch Decree agricultural water rights acquired by Power Company that would have been released to maintain Floriston rates, (2) re-storage of PCPOSW released from Independence Lake to another appropriate reservoir, or (3) implementing one of several mandatory and voluntary exchanges and transfers.

Fish credit water is water other than fish water that can be stored and used for the benefit of Pyramid Lake fish. Fish credit water can be accumulated during simulations by (1) retaining in storage that portion of pooled water not needed to immediately satisfy Orr Ditch Decree water rights and would have flowed to Pyramid Lake, and (2) implementing one of several mandatory and voluntary exchanges and transfers. A water category called Power Company emergency drought supply (PCEDS) consists of the first 7,500 acre-ft of fish credit water stored in Stampede Reservoir. Additionally, half of the fish credit water created becomes JPFCW until (1) JPFCW in all reservoirs totals 20,000 acre-ft, or (2) California exhausts its annual surface-water allocation.

Water-quality credit water (WQCW) is dedicated to augmenting instream flow in the Truckee River from the Truckee Meadows to Pyramid Lake to enhance water quality and preserve wildlife and fish habitat along the Truckee River. WQCW can be accumulated during simulations by three methods based on draft TROA principles in conjunction with WQSA. The first method of simulation involves reducing releases corresponding to the consumptive use of Orr Ditch Decree rights acquired by WQSA that would have been released to maintain Floriston rates. The water retained would be transferred to WQCW. The second method of simulation involves the accumulation of WQCW during periods when cui-ui flow targets are in effect at Nixon, downstream from Derby Dam. The volume of WQCW accumulated corresponds to the volume of pooled water flowing directly to Pyramid Lake that augments flow used for the benefit of Pyramid Lake fish in accordance to the consumptive use portion of acquired Orr Ditch Decree rights. The third method of simulation is an instream creation of WQCW within the Truckee River by transferring to WQCW that part of pooled water obligated to Orr Ditch Decree rights purchased for uses specified in WQSA.
Under draft TROA and WQSA, releases of credit water are simulated to meet downstream demands. Credit waters simulated to meet demands include releases of firm and nonfirm PCMICW and CMICW to meet M\&I and agricultural demands, releases of fish credit water to meet cui-ui flow targets, and releases of WQCW to meet water-quality targets. Additionally, direct diversions from Lake Tahoe and Donner and Independence Lakes are simulated to meet local M\&I demands.

Mandatory exchanges and transfers are simulated for moving (physically or administratively) or converting water categories among one or more reservoirs. These required exchanges and transfers are specified for certain water categories and purposes in draft TROA to allow the storage and release of water categories to meet more than one objective. Mandatory exchanges and transfers are simulated to (1) achieve enhanced minimum instream flows and (2) favor the storage of selected new credit water categories, depending on specific conditions such as reservoir storage on specific dates and the presence or absence of a drought situation.

The first type of simulated mandatory exchange provides for the enhancement of minimum instream flows using current and credit water categories accumulated in reservoirs. Enhanced minimum instream flows are simulated by (1) increasing reservoir releases of water categories if the water can be re-stored in a downstream reservoir or if the water can be exchanged into another reservoir, or (2) releasing JPFCW without re-storage or exchange. The exchange and re-storage of water categories for enhancing minimum flows depends on their security in storage, once re-stored or exchanged, their availability and location in reservoir storage before re-storage or exchange, type of season (normal or dry), and the current status of streamflow with respect to enhanced flow targets at specified locations.

Other mandatory exchanges and transfers are simulated based on category storage limits, drought situation, time of the year, or some combination of these criteria. These operations are simulated mostly as paper exchanges and transfers. These other exchanges and transfers are simulated to maintain firm PCMICW, nonfirm PCMICW, and PCEDS base amounts and to transfer PCPOSW and PCMICW stored in reservoirs on specific dates. 
Many exchanges are voluntary and are not specified individually in draft TROA. Voluntary exchanges would be requested by the parties interested in making the exchange and would be based on terms and conditions agreed to by the parties. Similar to mandatory exchanges, voluntary exchanges can satisfy several objectives. Because the number of potential voluntary exchanges is quite large, only four major types are simulated by the operations model and described in this report. These exchanges are used to (1) achieve preferred instream flows, (2) enhance storage security, (3) efficiently utilize precautionary drawdown releases, and (4) maintain recreational pools. For simulation, it is assumed that if conditions allow for a voluntary exchange, that voluntary exchange will be simulated.

One type of voluntary exchange provides for the achievement of preferred instream flows. Similar to enhanced instream flows, preferred flows are simulated as flow targets that vary by season and location. For most simulations, reservoir releases may be increased to achieve preferred flows only if the water can be re-stored or exchanged into another reservoir.

Another type of voluntary exchange, enhanced storage security exchanges, involves exchanging water to a reservoir that is more likely to allow an owner to keep and access that water. A voluntary exchange may allow credit water categories to be exchanged to a reservoir with safer storage conditions. The operations model simulates the most likely exchanges for enhanced storage security: (1) an exchange of credit water categories from Lake Tahoe or Prosser Creek Reservoir to Boca Reservoir, and (2) an exchange of water categories from Boca Reservoir to Stampede Reservoir. These simulated exchanges assume that Stampede provides the most secure storage for water categories.

A third type of voluntary exchange, efficient use of releases for precautionary drawdowns, allows precautionary drawdowns from a reservoir during floodcontrol operations to meet other objectives, such as maintenance of Floriston rates. Simulations provide three exchange possibilities: (1) a Donner-Tahoe exchange when precautionary drawdowns from Donner Lake may be substituted for Lake Tahoe pooled water releases, (2) a Prosser-Tahoe exchange when precautionary drawdowns from Prosser Creek Reservoir may be substituted for Tahoe pooled water releases, and (3) a Prosser-Boca exchange when pre- cautionary drawdowns from Prosser Creek Reservoir may be substituted for Boca Reservoir adverse-to-canal water releases.

A fourth type of voluntary exchange operation, maintenance of recreational pools, is the management of reservoir releases and exchanges to maintain recreational pools during the summer. Although recreational pool objectives are set for Donner and Independence Lakes and Prosser and Boca Reservoirs, exchanges are only simulated to maintain Boca recreational pool objectives. For reservoirs other than Boca, recreational pool objectives are simulated in consideration with the reservoir releases. For Boca, simulations provide inlieu-of exchange possibilities with Prosser Creek Reservoir and Lake Tahoe. The operations model does not simulate operations to meet Stampede Reservoir, Martis Creek Lake and Lake Tahoe recreational pools.

Simulations adjust reservoir storage accounts of water categories for evaporation losses and precipitation gains on the basis of priority guidelines provided in draft TROA. Additionally, simulated releases due to flood-control criteria use water categories based on rank-order guidelines. Similar to current operations, these merged reservoir releases, required for uncontrolled spills and precautionary drawdowns based on flood-control criteria, satisfy a variety of other objectives under draft TROA and WQSA. Priority orders may change if a drought situation exists.

Simulations use forecasts to evaluate expected runoff conditions that affect operations. The determination of normal and dry seasons is used to specify enhanced instream flow releases. The determination of a drought situation is used to determine the order of water category releases required under flood-control criteria and to determine if mandatory exchanges should take place that involve various water categories. As a surrogate for human judgement needed in making some operational decisions, a runoff index of wet, dry, or average is established by comparing forecasted runoff to mean runoff from historical records.

Traditional model development usually entails calibration and verification tasks in order to demonstrate the reliability of the model. However, testing of the Truckee River Basin operations model by comparison with historical data is difficult for several reasons. These include historical flexibility and lack of documentation in how operations were actually implemented, as well as the lack of past input data to simulate all of the details and system interactions of past operations. Thus, only limited testing of the USGS 
Truckee River Basin operations model by comparison with historical data can be accomplished. Because draft TROA has not yet been implemented, no observed data reflecting proposed operations are available for comparison to simulated data.

With these limitations in mind, the periods 1989-97 and 1933-97 were chosen to illustrate model simulations compared to historically observed streamflows.

The period 1989-97 was chosen to test simulation of reservoir and river operations because it includes all current reservoirs and is the most representative of the current operating strategy coded in the model. Current operations were simulated and simulated streamflows at the Farad, Vista, and Nixon gaging stations were graphically compared to observed values. Differences between observed and simulated flows at the gaging stations for the periods 1989 and 1994 were probably the result of simulated reservoir storages that were different from observed storages and single incident variances in actual operations or operations based on special permits or agreements not simulated by the model.

The period 1933-97 was chosen to illustrate longterm differences between simulated and observed streamflow volumes at the Farad gaging station. For the entire period, the percent bias of simulated streamflow was -13 percent. For the periods $1933-80$ and 1981-97, percent biases of simulated streamflow at the Farad gaging station were -18 and -2 percent, respectively. Differences between the inflow data used in model simulations and actual inflows between the outflow of Lake Tahoe and Farad are an important reason for the negative bias between simulated and observed flows. It is likely that errors from PRMS simulations of inflows to the operations model, the use of synthetic meteorological data used as input for PRMS simulations, and different reservoir configurations contribute toward the negative bias at Farad prior to 1981. Operational variables, such as different effective dates of decrees and agreements, flexible adherence to decrees and agreements, and other unknown or minor operational variables, may also influence simulation results, but their influence on simulation results is difficult to specify.

\section{REFERENCES CITED}

Berris, S.N., 1996, Daily flow-routing simulations for the Truckee River, California and Nevada: U.S. Geological Survey Water-Resources Investigations Report, 964097, 83 p.

Berris, S.N., Hess, G.W., and Cartier, K.D., 1996, Simulation of selected reservoir operations in the upper Truckee River Basin, California: U.S. Geological Survey Fact Sheet FS-082-96, 4 p.

Berris, S.N., Hess, G.W., and Bohman, L.R., 2001, Hydrologic data used in the river and reservoir operations model, 1933-97, Truckee River Basin, California and Nevada: U.S. Geological Survey Open-File Report 00-478, $48 \mathrm{p}$.

Bicknell, B.R., Imhoff, J.C., Kittle, J.L., Donigan, A.S., and Johanson, R.C., 1993, Hydrological simulation program-FORTRAN: User's manual for release 10: EPA/600/R-93/174, Environmental Research Laboratory, $660 \mathrm{p}$.

Brown, W.M. III, Nowlin, J.O., Smith, L.H., and Flint, M.R., 1986, River-quality assessment of the Truckee and Carson River System, California and Nevada—hydrologic characteristics: U.S. Geological Survey Open-File Report 84-576, $201 \mathrm{p}$.

Buchanan, C.C., and Strekal, T.A., 1988, Simulated water management and evaluation procedures for cui-ui: U.S. Fish and Wildlife Service, 19 p.

Bureau of Reclamation, 1959, Agreement for water exchange operations of Lake Tahoe and Prosser Creek Reservoir: Contract No. 14-06-400-957, 10 p.

1988, Secretarial record of decision on the Newlands Project Operation Criteria and Procedures: Mid-Pacific Regional Office, Sacramento, California, 22 p. with appendices.

1994, Contract for the storage of non-project water among Sierra Pacific Power Company, Washoe County Water Conservation District, Pyramid Lake Paiute Tribe, and the United States of America: Contract No. 4-07-20-W1177, $23 \mathrm{p}$.

1997, Adjustments to 1988 Operating Criteria and Procedures (OCAP) for the Newlands Irrigation Project in Nevada; Final Rule: Federal Register, v. 62, no. 243, p. 66441-66485.

Bureau of Reclamation, U.S. Fish and Wildlife Service, and California Department of Water Resources, 1998, Draft Environmental Impact Statement/Environmental Impact Report-Truckee River Operating Agreement, $659 \mathrm{p}$.

Butcher, W.S., Gupta, V.L., Fordham, J.W., and Miller, R.E., 1969, Simulation theory applied to water resources management: Desert Research Institute Technical Report H-W 7, 56 p. 
Chiatovich, T.D., Fordham, J.W., 1979, A reservoir operating model with inorganic quality constraints for the Truckee River: Water Resources Bulletin, V. 15, no. 2, p. 301-315.

Cobb, E.D., Olson, A.F., Moosburner, Otto, Pupacko, Alex, 1990, Review of selected water-management models and results of simulations for the Truckee-Carson Rivers System, California and Nevada: U.S. Geological Survey Open-File Report 90-393, 40 p.

Day, G.N., 1985, Extended streamflow forecasting using NWSRFS: Journal of Water Resources Planning and Management, vol. 111, no. 2, p. 157-170.

Dettinger, M.D. and Cayan, D., 1996, Large-scale atmospheric forcing of recent trends towards early snowmelt runoff in California: J. of Climate, vol. 8, no. 3, p. 606-623.

Fordham, J.W., 1972, Simulation theory applied to water resources management, phase III Development of optional operating rules: Desert Research Institute Technical Report H-W 13, 45 p.

Fordham, J.W., and Butcher, W.S., 1970, Simulation theory applied to water resources management, phase II: Desert Research Institute Technical Report H-W 10, $50 \mathrm{p}$.

Hardman, George, 1965, Nevada precipitation map: Nevada Division of Conservation and Natural Resources Report, 27 p.

Harris, E.E., 1970, Reconnaissance bathymetry of Pyramid Lake, Washoe County, Nevada: U.S. Geological Survey Hydrologic Investigations Atlas HA-379, 1 map.

Heki, L.G., 1994, Cui-ui and Lahontan cutthroat trout spawning runs at Marble Bluff Fish Facility, 19881993: U.S. Fish and Wildlife Service, 19 p.

Heki, L.G., and Cowan, W.C., 1994, Summary of cui-ui and Lahontan cutthroat trout data, Marble Bluff Fish Facility, 1994: U.S. Fish and Wildlife Service, 3 p.

Hess, G.W., 1996, Progress report on daily flow-routing simulation for the Carson River, California and Nevada: U.S. Geological Survey Open-File Report, 96-211, $41 \mathrm{p}$.

1997, Simulation of selected river diversion operations in the upper Carson River Basin, California and Nevada: U.S. Geological Survey Fact Sheet FS-240-96, $4 \mathrm{p}$.

Horton, Gary, 1997a, Truckee River chronology-A chronological history of Lake Tahoe and the Truckee River and related water issues: Nevada Water Basin Information and Chronology Series, Nevada Division of Water Planning, $216 \mathrm{p}$.

1997b, Carson River chronology —A chronological history of the Carson River and related water issues: Nevada Water Basin Information and Chronology Series, Nevada Division of Water Planning, 213 p.
Jeton, A.E., 1999, Precipitation-runoff simulations for the Lake Tahoe Basin, California and Nevada: U.S. Geological Survey Water-Resources Investigations Report 99-4110, 61 p.

2000, Precipitation-runoff simulations for the upper part of the Truckee River Basin, California and Nevada: U.S. Geological Survey Water-Resources Investigations Report 99-4282, 41 p.

Jones, Jeanine, Maxwell, S.R., and Hayward, Patricia, 1991a, Truckee River atlas: California Department of Water Resources, 128 p.

Jones, Jeanine, Maxwell, S.R., and Wieking, James, 1991b, Carson River atlas: California Department of Water Resources, $132 \mathrm{p}$.

Kittle, J.L., Jr., Lumb, A.M., Hummel, P.R., Duda, P.B., and Gray, M.H., 1998, A tool for the generation and analysis of model simulation scenarios for watersheds (GENSCN): U.S. Geological Survey Water Resources Investigations Report 98-4134, 152 p.

Langbein, W.B., and Iseri, K.T., 1960, General introduction and hydrologic definitions: U.S. Geological Survey Water-Supply Paper 1541-A, 29 p.

Leavesley, G.H., Lichty, R.W., Troutman, B.M., and Saindon, L.G., 1983, Precipitation-runoff modeling system: user's manual: U.S. Geological Survey WaterResources Investigations Report 83-4238, 207 p.

Lumb, A.M., Kittle, J.L., and Flynn, K.M., 1990, Users manual for ANNIE, a computer program for interactive hydrologic analyses and data management: U.S. Geological Survey Water-Resources Investigations Report 89-4080, 236 p.

Maurer, D.K., 1986, Geohydrology and simulated response to ground-water pumpage in Carson Valley, a riverdominated basin in Douglas County, Nevada, and Alpine County, California: U.S. Geological Survey Water Resources Investigations Report 86-4328, 109 p.

McGauhey, P.H., Eliassen, Rolf, Rohlich, Gerard, Ludwig, H.F., and Pearson, E.A., 1963, Comprehensive study on protection of water resources of Lake Tahoe Basin through controlled waste disposal: Arcadia, Calif., Engineering Science, Inc., 157 p.

Pyramid Lake Paiute Tribe of Indians and Sierra Pacific Power Company, 1989, Preliminary Settlement Agreement between Pyramid Lake Paiute Tribe of Indians and Sierra Pacific Power Company: Reno, Nev., Sierra Pacific Power Company, $30 \mathrm{p}$.

Strekal, T.A., Cooper, J.J., Curran, Jim, Minckley, W.L., Scoppettone, G.G., Vinyard, Gary, and Wagner, Paul, 1992, Cui-ui recovery plan, second revision: U.S. Fish and Wildlife Service, Region 1, 47 p.

U.S. Army Corps of Engineers, 1985, Truckee River Basin reservoirs, Truckee River Basin Nevada and California: Water Control Manual, 99 p. 
U.S. Geological Survey, 1974-1975, Water resources data for Nevada, 1971-1974: U.S. Geological Survey Water-Data Reports (published annually).

1976-1997, Water resources data, Nevada, water years 1975-1996: U.S. Geological Survey Water-Data Reports NV-75-1 to NV-96-1 (published annually).

1998, Water resources data, Nevada, water year 1997: U.S. Geological Survey Water-Data Report NV-97-1, $636 \mathrm{p}$.

Van Denburgh, A.S., and Arteaga, F.E., 1985, Revised water budget for the Fernley area, west-central Nevada, 1979: U.S. Geological Survey Open-File Report 84-712, 17 p.

Westphal, J.A., Sharp, J.V., and Bateman, R.L., 1974, Water quality simulation of Tahoe-Truckee System, California and Nevada: Desert Research Institute Technical Report H-W 15, 67 p.

Yardas, D.E., 1996, Below Lahontan Reservoir model: Reno, Nev., U.S. Fish and Wildlife Service, Documentation and User Guide, version 3, 63 p.

\section{GLOSSARY}

Selected technical terms used in this report are defined for convenience of the reader. See Langbein and Iseri (1960) for additional information regarding hydrological terminology.

additional supplemental storage water. Also referred to as non-adverse-to-canal (Truckee Canal) water, this term means all water diverted to and stored in Boca Reservoir in excess of supplemental storage water (adverseto-canal water), but not including credit water, privately owned stored water, and project water from another reservoir. See also supplemental storage water.

ANNIE. A time-series data-management system that allows a user to interactively store, retrieve, list, plot, check, update, or statistically analyze spatial, parametric, and time-series data for hydrologic models.

Boca pressure water. Fish water or fish credit water, released from Stampede Reservoir for temporary storage in Boca Reservoir, that provides sufficient hydraulic head at the outlet works to enable timely releases to achieve flow targets for the benefit of Pyramid Lake fish.

California M\&I credit water (CMICW). Water that may be stored for M\&I use in California according to draft TROA.

category. Any block of water that is individually accounted for in an observed or simulated water budget and that may have specific ownership, such as privately owned stored water, or a designated use, such as pooled water. consumptive use duty. The total volume of irrigation water per year required to mature an acre of a particular type of crop. The duty is the annual amount of water supplied to the land, including transmission losses from the point of diversion at the river to the farm headgate, and is not the volume of water actually consumed by the plants. Transmission losses are not included in the consumptive use duty applied to M\&I diversions.

contract storage. Interim Storage Agreement as authorized under paragraph 205(b)(3) of P.L. 101-618 among the Secretary of the Interior, Sierra Pacific Power Company, Washoe County Water Conservation District, and the Pyramid Lake Paiute Tribe (Contract for Storage of SPPC Water in Stampede and Boca Reservoirs).

controlled spill. See precautionary drawdown.

credit water. Water that is accumulated, stored, and released in accordance with provisions in draft TROA. Categories included are fish credit water, firm Power Company M\&I credit water, nonfirm Power Company M\&I credit water, California M\&I credit water, Water Quality credit water, Joint program fish credit water, Fernley credit water, Newlands Project credit water, and other credit water (water stored and used for beneficial uses that are not currently defined in draft TROA).

depletion. The amount of diverted water that is consumptively used and, therefore, not returned to the river or aquifer.

displacement. The forced release of one water category from a reservoir because of a higher priority for storage of another water category during a spill.

drought condition. As identified in draft TROA, a condition under which the Power Company's normal water supply is not sufficient to satisfy normal M\&I water year demand and a drought situation exists.

drought situation. As identified in draft TROA, situation in which the Truckee River runoff forecast indicates there would not be sufficient unregulated water and pooled water to maintain Floriston rates throughout the water year, or Lake Tahoe elevation is forecasted to drop below 6,223.5 ft (Lake Tahoe datum) before November 15.

dry season. As identified in draft TROA, a range of forecasted runoff in the Truckee River Basin downstream from Lake Tahoe and the amount of water in Lake Tahoe at various times of the year, defined by figures 5 and 6 . Along with normal season, these thresholds were established to integrate forecasting into an operation that would assure that water rights would not be impaired while improving the prospects of enhancing minimum instream flow.

efficiency. Efficiency is computed as the total amount of water delivered to water-rights holders at the farm headgates divided by total diversion to the water-distri- 
bution system. Low efficiencies mean that conveyance/transit losses, such as seepage, evaporation, or other operational losses, are large.

enhanced minimum instream flows. Mandatory target flows, identified in draft TROA, used to benefit fish and river habitat in California, to be achieved through the use of credit water, privately owned stored water, or fish water only if such waters could be re-stored in another reservoir or exchanged for water in another reservoir.

exchange. As identified in draft TROA, a transaction of specific quantities and water categories among reservoirs by any of three methods: (1) nonphysical exchange of a volume of water in one or more reservoirs for an equal volume of water in one or more other reservoirs, often called a "paper exchange;" (2) release of one or more categories of water from one or more reservoirs in lieu of a release of water of yet another category from one or more other reservoirs, often called an "in-lieu-of exchange" and; (3) release of water from one reservoir for storage in a downstream reservoir, often called "re-storage."

Extended Streamflow Prediction (ESP). A computer program developed by the National Weather Service that uses existing snowpack conditions and applies historical temperature and precipitation values of a user-specified exceedance level over a future period of time (length of prediction also is user-specified) in order to predict streamflow rates or volumes.

F- Table. Function tables of the RCHRES block that contain relations between hydraulic properties of channel reaches, lakes, and reservoirs.

Fernley credit water. As identified in draft TROA, water that may be stored and utilized by the town of Fernley for M\&I purposes.

firm Power Company M\&I credit water (firm PCMICW). As identified in draft TROA, water stored in Stampede Reservoir that can be utilized for M\&I purposes under drought conditions.

fish credit water (FCW). As identified in draft TROA, water, other than fish water, that can be stored and utilized for the benefit of Pyramid Lake fish.

fish water. Stampede Reservoir project water and uncommitted water in Prosser Creek Reservoir held or released into the Truckee River for the benefit of Pyramid Lake fish.

Floriston rates. Mandatory Truckee River flow rates, first established by the Truckee River General Electric Degree in 1915 as minimum-flow criteria for the Truckee River at the California-Nevada boundary. former agricultural right. As identified in draft TROA, a water right from the Truckee River or its tributaries, originally used for irrigation in accordance with the Orr Ditch Decree, that has been purchased or otherwise acquired for uses other than agricultural.

gaging station. A gaging station where a continuous record of discharge, stage, or water-quality parameters is obtained.

GENeration and analysis of model simulation SCeNarios (GENSCN). The graphical user-interface developed to aid operational model simulations by creating, running, and analyzing alternative water-management scenarios.

in-lieu-of exchange. See exchange.

instream flow transfer. Creation of water-quality credit water instream (as flow within the river) rather than as water not released, and thus held as storage within a reservoir. Instream flow transfers are limited to those times when Truckee River flows are less than specified water-quality targets (see also transfer).

irrigation return flow. Excess surface water or ground water that returns to the river after diversion or application for irrigation.

irrigation season. Generally, the 7-month period beginning April 1 and ending October 31 of any year.

joint program fish credit water (JPFCW). As identified in draft TROA, fish credit water that may be stored and utilized for recreational pool and instream flow purposes in California, after which the water must flow unimpeded to Pyramid Lake.

municipal and industrial. Water supplied through a public water system for use in residential areas, commercial establishments, industry, landscape irrigation, or for other public needs.

natural water. Water that originates from flow in Truckee River tributary subbasins not regulated by a reservoir or from flow that is passed through a reservoir without detention, except Lake Tahoe.

Newlands Project credit water. Water that may be stored and utilized for use in satisfying OCAP requirements for the Newlands Project.

nondrought situation. See drought situation.

nonfirm Power Company M\&I credit water (nonfirm PCMICW). As identified in draft TROA, any water other than Power Company POSW or firm Power Company M\&I credit water that can be stored in any Truckee River reservoir and utilized for Power Company M\&I purposes.

normal season. See dry season.

observed data. Lake-level or streamflow data computed from gage-height records collected at continuousrecorder or intermittent-observation gaging stations. 
Operating Criteria and Procedures (OCAP). Federal regulation governing diversion of water from the Truckee River for the Newlands project and operations for providing water to the Newlands Project, with the objective of maximizing use of Carson River water and minimizing diversion of Truckee River water.

other credit water. As identified in draft TROA, water that may be stored and utilized for beneficial uses not defined at this time.

paper exchange. See exchange.

pass-through. That part of reservoir inflow not allowed to be stored in order to meet demands or storage rights downstream having a higher legal priority.

pondage. That portion of Boca Reservoir that provides 800 acre-ft of storage capacity to facilitate the use of regulating flow for power generation and meeting Floriston rates as defined in the Truckee River Agreement.

pooled water. Water stored pursuant to the Orr Ditch Decree and the Truckee River Agreement and allocated to the maintenance of Floriston rates.

Power Company emergency drought supply (PCEDS). As identified in draft TROA, water stored in Stampede Reservoir that can be utilized by the Power Company for M\&I purposes under drought conditions.

Power Company M\&I credit water. See firm Power Company M\&I credit water and nonfirm Power Company M\&I credit water.

precautionary drawdown. For reservoirs with dedicated flood-control space, reservoir releases generally made during the period from about late summer to November 1. Reservoirs that do not have dedicated flood-control space or other operating criteria requiring wintertime drawdown, such as Lahontan Reservoir or Lake Tahoe, typically have precautionary drawdown or reservoir releases in late winter or early spring. Also termed controlled spills, these releases are made to reduce reservoir levels to a prescribed limit that allows for emergency flood-control space, mostly during the winter and early spring months, but such releases could be made anytime that a situation merits (see also spill).

preferred flows. Target flows, identified in draft TROA, that are greater than enhanced minimum instream flows.

priority date. Date a water right is established; used to chronologically determine the relative priority of water rights.

privately owned stored water (POSW). Water stored pursuant to water rights of Power Company in Independence Lake and the water rights of Power Company and TCID in Donner Lake.

project water. Water initially stored as pooled water in Lake Tahoe, supplemental storage water (adverse-tocanal), additional supplemental storage (non-adverseto-canal), and pondage water in Boca Reservoir, Stam-
pede-Reservoir project water in Stampede Reservoir, Tahoe-Prosser Exchange water and uncommitted water in Prosser Creek Reservoir, and privately owned stored water in Donner and Independence Lakes.

re-storage. See exchange.

reach. A reservoir or a section of river having relatively uniform hydraulic properties and used within HSPF to simulate the movement of water within a hydrologic network.

recreational pool. Minimum reservoir storage levels that are maintained to promote or enhance public uses, such as boating and fishing.

recreational season. The period between the dates April 1 and September 3 (assumed to be the Labor Day holiday).

sidewater. Unregulated inflows of natural water from tributary subbasins in the Truckee River Basin.

spill. Spills can be either controlled or uncontrolled. Controlled spills (often termed precautionary drawdowns) are planned releases generally made in compliance with flood-control criteria or dam safety criteria. Uncontrolled spills are unplanned releases that occur when there is no reservoir storage capacity. In uncontrolled spills at reservoirs where river outlet works exist, reservoir inflows exceed the capacity of the river outlet works and water passes over the spillway without going through river outlet works.

spring filling season. The period when the reservoirs can be filled with spring runoff up to maximum allowable storage capacity.

supplemental storage water. Also referred to as adverse-tocanal water, this term refers to the first 25,000 acre-ft of water stored (or, if a lesser quantity is stored, then such lesser quantity) in Boca Reservoir during any year commencing October 1 and ending September 30 of the following year.

Tahoe-Prosser Exchange water (TPEW). Water stored in Prosser Creek Reservoir in accordance with the TahoeProsser Exchange Agreement that is classified as Lake Tahoe storage and used to maintain Floriston rates in conjunction with minimum releases from Lake Tahoe.

threshold volume. Daily storage volumes specified as constraints to mandatory exchange criteria in draft TROA and as constraints to several miscellaneous operations simulated by the operations model. The threshold volumes provide for the safety of stored, re-stored, or exchanged water from the threat of reservoir spill when reservoir volumes are large or of limited outlet capacity, recreation potential, or water category availability when reservoir volumes are small.

transfer. A mechanism in draft TROA for establishing storage of certain credit water categories in a reservoir. Transfers, unlike exchanges, involve only one reservoir, and the sum of the releases from all reservoirs may 
be modified as a result of this operation. In a transfer, there is a gain in volume for one water category, coincident with the loss of an equal volume of water from another water category in the same reservoir (see also instream flow transfer).

uncommitted water. Water stored in Prosser Creek Reservoir pursuant to its California water right and used for the purposes of the Tahoe-Prosser Exchange Agreement and the benefit of threatened and endangered fish of Pyramid Lake. Such water does not include dead storage and inactive storage, privately owned stored water, credit water, Tahoe-Prosser Exchange water, and project water from another reservoir.

uncontrolled spill. See spill.

user's control input (UCI). Computer file containing specifications that control HSPF simulations.

water balance. An accounting of the inflow to, outflow from, and storage in a hydrologic unit.

water-quality credit water (WQCW). As identified in draft TROA, water acquired and dedicated to waterquality purposes pursuant to the Truckee River Water Quality Agreement.

water year. The 12-month period beginning October 1 and ending September 30, and designated by the calendar year of the ending date.

wintertime cap. A prescribed, less-than-full reservoir storage level maintained usually from about November to March or April each year that provides adequate flood-control space to reduce the threat of downstream flood damage or provides space required by safety of dams criteria. 
